UNIVERSIDADE DE SÃO PAULO

FACULDADE DE EDUCAÇÃO

KATE MAMHY OLIVEIRA KUMADA

Acesso do surdo a cursos superiores de formação de professores de

Libras em instituições federais

Versão corrigida

SÃO PAULO 
KATE MAMHY OLIVEIRA KUMADA

Acesso do surdo a cursos superiores de formação de professores de

Libras em instituições federais

Tese apresentada ao Programa de Pós-graduação em educação da Faculdade de Educação da Universidade de São Paulo para obtenção de título de Doutorado em Educação.

Linha de pesquisa: Educação especial

Orientadora: Profa. Dra. Rosângela Gavioli Prieto

Versão corrigida

SÃO PAULO

2017 
Autorizo a reprodução e divulgação total ou parcial deste trabalho, por qualquer meio convencional ou eletrônico, para fins de estudo e pesquisa, desde que citada a fonte.

\author{
Catalogação na Publicação \\ Serviço de Biblioteca e Documentação \\ Faculdade de Educação da Universidade de São Paulo
}

371.912 Kumada, Kate Mamhy Oliveira

K96a

Acesso do surdo a cursos superiores de formação de professores de Libras em instituições federais / Kate Mamhy Oliveira Kumada; orientação Rosângela Gavioli Prieto. São Paulo: s. n., 2017. Versão corrigida.

245 p.; ils.; grafs.; tabs.

Tese (Doutorado - Programa de Pós-Graduação em Educação. Área de Concentração: Educação Especial) - Faculdade de Educação da Universidade de São Paulo.

1. Língua Brasileira de Sinais 2. Formação de professores

3. Ensino superior 4. Bilinguismo 5. Surdo 6. Estudos surdos

I. Prieto, Rosângela Gavioli, orient. 
KUMADA, Kate Mamhy Oliveira. Acesso do surdo a cursos superiores de formação de professores de Libras em instituições federais. Tese apresentada à Faculdade de Educação da Universidade de São Paulo para a obtenção do título de Doutora em Educação.

Aprovado em:

\section{Banca Examinadora}

Profa. Dra. Rosângela Gavioli Prieto

Instituição: Universidade de São Paulo

Julgamento:

Assinatura:

Profa. Dra. Adriana da Silva Thoma Instituição: Universidade Federal do Rio Grande do Sul

Julgamento: Assinatura:

Profa. Dra. Márcia Lise Lunardi-Lazzarin Instituição: Universidade Federal de Santa Maria Julgamento: Assinatura:

Profa. Dra. Marilda do Couto Cavalcanti Instituição: Universidade Estadual de Campinas Julgamento: Assinatura: Assinatura: 
DEDICATÓRIA

Aos meus familiares e amigos, pelo carinho e apoio sempre.

Aos meus amigos surdos, por terem me acolhido e me ensinado a língua de sinais e a cultura surda. 


\section{AGRADECIMENTOS}

À professora Dra. Rosângela Gavioli Prieto por ter me acolhido como sua orientanda, depositado sua confiança em mim e contribuído imensuravelmente para meu amadurecimento acadêmico. Por ter dosado com sabedoria os momentos em que era necessário problematizar e me desestabilizar, reservando ainda situações para me incentivar e elogiar. Registro, assim, meu carinho e admiração pela pessoa e profissional que representa.

Às professoras Dra. Adriana da Silva Thoma e Dra. Márcia Lise Lunardi-Lazzarin não só pela leitura atenciosa e pelos valiosos apontamentos realizados durante o exame de qualificação, bem como pela presença e contribuições como membros da banca de defesa.

Às professoras Dra. Marilda do Couto Cavalcanti e Dra. Cássia Geciauskas Sofiato por aceitarem compartilhar seus conhecimentos e impressões durante a participação na banca de defesa.

À professora Dra. Ivani Rodrigues Silva pela presença constante em minha vida pessoal e acadêmica, pela amizade, pela parceria em projetos do contexto educacional bilíngue para surdo, pelas oportunidades e reflexões teóricas partilhadas.

Às professoras Dra. Wilma Favorito, Dra. Janete Mandelblatt e Dra. Yrlla Ribeiro de Oliveira Carneiro da Silva, por terem me recebido no Ines, cedendo tempo para o diálogo, materiais e informações sobre o curso bilíngue de Pedagogia da referida instituição.

Aos professores que participaram de minha formação durante o curso de doutorado, em especial, à professora Dra. Shirley Silva pelos textos apresentados e pelas produtivas discussões deflagradas em sua disciplina.

Aos colegas de pós-graduação por dividirem comigo esse momento de construção dos saberes pedagógicos na educação especial. Deixo particular agradecimento aos queridos colegas Claudine, Eliza, Mary, Fábio, Rubens, Verônica, Ingrid, Raquel, Fernanda, Roseli, Virgínia, Juliana, Beatriz, Fábia, Roseane e Lisiane. 
Aos bibliotecários da Feusp Thiago Gaudêncio Siebert Freire e Antônio Marcos Amorim por terem me auxiliado em várias ocasiões em relação à normatização do trabalho acadêmico.

A todos os meus amigos e familiares pelo apoio, especialmente, aos meus pais Iraci Aparecida Oliveira e Paulo Kumada (in memoriam) aos quais sempre busquei dar orgulho.

Pelo companheirismo e amor do meu marido João Elói de Oliveira Fritz que, pacientemente, entendeu minhas ausências e, ainda assim, encorajou-me durante o doutoramento.

Aos surdos, fonte de motivação para o meu trabalho. 
[...] direi que este texto se pergunta outras coisas, vibra com outras questões, se suicida a cada passo e comete muitos erros. Trata-se, todavia, de um texto feito com a cabeça erguida. E com o corpo fragmentado. Um texto que não quis responder a nada nem a ninguém, mas simplesmente para voltar e olhar bem. E olhar bem, novamente, para que a mesmidade se comova e se atormente de uma vez. Para que quando o outro volte, nos convide a seu mistério, nos faça diferença, nos difira.

Carlos Skliar 


\section{RESUMO}

KUMADA, Kate Mamhy Oliveira. Acesso do surdo a cursos superiores de formação de professores de Libras em instituições federais. 2016. 252 f. Tese (Doutorado) - Faculdade de Educação, Universidade de São Paulo, São Paulo, 2016. [Versão corrigida].

As últimas décadas têm desvelado grandes transformações na educação de surdos, uma delas consiste no deslocamento da abordagem, predominantemente, oralista para a perspectiva bilíngue, na qual a Língua brasileira de sinais (Libras) é reconhecida como a primeira língua dos surdos. Para a concretização dessa educação bilíngue, o Decreto ${ }^{\circ} 5.626 / 05$, entre outras disposições, estabeleceu a formação e atuação de professores de Libras, determinando aos surdos a prioridade em ambas as situações. Baseado nesse contexto, propusemos como objetivo geral desta pesquisa investigar e analisar o acesso dos surdos a cursos superiores de formação de professores de Libras em instituições federais. Para isso, alinhamo-nos aos pressupostos metodológicos da abordagem qualitativa, especialmente sobre a pesquisa documental e a análise de conteúdo. Para geração dos dados, nosso corpus proveio de 80 editais (e seus respectivos 217 documentos anexos e complementares) de processos seletivos para ingresso em cursos de educação superior voltados à formação de professores de Libras, sendo adotado como recorte o período de 2006 a 2015 e os editais pertencentes às instituições federais. Ancorados em uma ótica da surdez como diferença, cujas implicações reverberaram, principalmente, em uma visão crítica e ampliada de língua, bi/multilinguismo de minorias e identidades fragmentadas e multifacetadas, buscamos aporte nos Estudos Culturais e Estudos Surdos em educação e na Linguística Aplicada. À luz dessa fundamentação teórica, organizamos nossos dados para apresentação e discussão dos resultados em três eixos, 11 categorias e três subcategorias de análise. Os resultados apontaram para um quantitativo ainda escasso de vagas ofertadas nacionalmente para a formação de professores de Libras, sobretudo no segmento que abrange a educação infantil e os anos iniciais do ensino fundamental. Foi constatada ainda uma grande dificuldade por parte das instituições federais investigadas em: propiciar as condições de acessibilidade durante os processos seletivos, sendo muitas vezes observada a omissão de adequações ou a burocratização no seu deferimento; interpretar a prioridade reservada aos candidatos surdos, evidenciando o dissenso sobre quais critérios adotar ou quantas vagas devem ser destinadas a esse grupo de pessoas; realizar a articulação entre a prioridade para surdos e a Política de Ação Afirmativa para estudantes de escolas públicas, autodeclarados pretos, pardos e indígenas ou com baixa condição socioeconômica, aceitando que o indivíduo pode ser, simultaneamente, concebido como surdo, pobre, negro ou índio. Ademais, foi flagrante a presença da concepção patológica do surdo ainda muito arraigada nas exigências e nos textos dos editais e provas analisados, e uma visão essencializada das competências linguísticas do sujeito surdo e da noção de identidade. Esperamos, com nossa pesquisa, trazer à baila reflexões e questionamentos que contribuam para essa discussão, principalmente no tocante ao direito de acesso dos surdos aos cursos de formação de professores de Libras.

Palavras-chave: Língua brasileira de sinais. Formação de professores. Ensino superior. Bilinguismo. Surdo. Estudos surdos. 


\begin{abstract}
KUMADA, Kate Mamhy Oliveira. Access of deaf to higher education on Libras teacher training in federal institutions. 2017. 252 f. Thesis (PhD) - Faculdade de Educação, Universidade de São Paulo, São Paulo, 2017. [Revised Version].
\end{abstract}

The last decades have unveiled major changes in education of deaf, one of them is the shift of approach, predominantly oral, for bilingual perspective in which the Brazilian sign language (Libras) is recognized as the first language of deaf. To achieve this bilingual education, the Decree No. 5.626/05, among other things, established the formation and performance of Libras teachers, determining the priority for deaf in both situations. Based on this context, we set as the general objective of this research to investigate and analyze the access of deaf to higher education on Libras teacher training in federal institutions. For this, we align to the methodological principles of qualitative approach, especially on the documentary research and content analysis. To generate data, our corpus came from 80 public notices (also 217 appendixes and supporting documents) of selection processes to begin higher education courses directed to training Libras teachers, being adopted as clipping the period from 2006 to 2015 and the notices belonging to federal institutions. Anchored in a perspective of deafness as a difference whose implications reverberated mainly in a critical and expanded view of the language, bi/multilingualism of minorities and fragmented/multifaceted identities, we sought input in Cultural Studies and Deaf Studies in Education and Applied Linguistics. In light of this theoretical basis, we organized our data for presentation and discussion of the results in three axes, 11 categories and three subcategories of analysis. The results pointed to a still limited quantity of vacancies offered nationally for the Libras teachers' qualification, especially in the segment covering kindergarten and the early years of elementary school. It was also found great difficulty by investigated federal institutions in: providing conditions for accessibility during the selection process, often observed the omission of adequacy or bureaucratization in its approval; interpret the priority reserved for deaf applicants, showing disagreement on what criteria to adopt or how many openings should be attributed to this group of people; conduct the relationship between the priority for the deaf and the Affirmative Action Policy for public school students, self-declared black, mulattos and indigenous and / or on low socioeconomic status, accepting that the individual can be simultaneously designed as deaf, poor, black or indian. Furthermore, it was notorious the presence of pathological conception of deaf still deeply rooted in the requirements and in the texts of the analyzed notices and tests, and a grounded view of the deaf language skills and the notion of identity. We hope with our research to bring up thoughts and questions that contribute to this discussion, particularly regarding to the right of access of deaf to Libras teacher training courses.

Keywords: Brazilian sign language. Teacher training. Higher education. Bilingualism. Deaf. Deaf studies. 


\section{LISTA DE SIGLAS}

Aasi Aparelho de Amplificação Sonora Individual

BDTD Biblioteca Digital Brasileira de Teses e Dissertações

BTDC Banco de Teses e Dissertações da Capes

Capes Coordenação de Aperfeiçoamento de Pessoal de Nível Superior

CF Constituição Federal

CID Classificação Internacional de Doenças

CNE Conselho Nacional de Educação

CPF Cadastro de Pessoas Físicas

CR Coeficiente de Rendimento

dB Decibéis

DOU Diário Oficial da União

$\mathrm{EaD} \quad$ Educação a distância

Enem Exame Nacional do Ensino Médio

Feneis Federação Nacional de Educação e Integração de Surdos

Funai Fundação Nacional do Índio

IBGE Instituto Brasileiro de Geografia e Estatística

IES Instituição de Educação Superior

Ifes Instituição Federal de Educação Superior

IFG Instituto Federal de Educação, Ciência e Tecnologia de Goiás

Inep Instituto Nacional de Estudos e Pesquisas Educacionais Anísio Teixeira

Ines Instituto Nacional de Educação de Surdos

L1 Primeira língua

L2 Segunda língua

Libras Língua brasileira de sinais

LDB Lei de Diretrizes e Bases da Educação Nacional

MEC Ministério da Educação

Nuppes Núcleo de Pesquisa em Políticas de Educação para Surdos

PAA Política de Ação Afirmativa

Paaes Programa de Ação Afirmativa de Ingresso no Ensino Superior

PAR Plano de Ações Articuladas para a Formação de Professores

Parfor Plano Nacional de Formação de Professores da Educação Básica

PNE Plano Nacional de Educação

Prolibras Exame Nacional para Certificação de Proficiência no uso e no ensino de Libras e para certificação de proficiência na tradução e interpretação de Libras/Língua Portuguesa

SciELO Scientific Eletronic Library Online

Sisu Sistema de Seleção Unificada

SME/SP Secretaria Municipal de Educação de São Paulo

Udesc Universidade do Estado de Santa Catarina

Ufac Universidade Federal do Acre

Ufal Universidade Federal de Alagoas 


$\begin{array}{ll}\text { Ufam } & \text { Universidade Federal do Amazonas } \\ \text { UFC } & \text { Universidade Federal do Ceará } \\ \text { Ufersa } & \text { Universidade Federal Rural do Semiárido } \\ \text { UFG } & \text { Universidade Federal de Goiás } \\ \text { UFGD } & \text { Universidade Federal da Grande Dourados } \\ \text { UFJF } & \text { Universidade Federal de Juiz de Fora } \\ \text { UFMA } & \text { Universidade Federal do Maranhão } \\ \text { UFMT } & \text { Universidade Federal do Mato Grosso } \\ \text { UFPA } & \text { Universidade Federal do Pará } \\ \text { UFPB } & \text { Universidade Federal da Paraíba } \\ \text { UFPE } & \text { Universidade Federal de Pernambuco } \\ \text { UFPI } & \text { Universidade Federal do Piauí } \\ \text { UFPR } & \text { Universidade Federal do Paraná } \\ \text { Ufra } & \text { Universidade Federal Rural da Amazônia } \\ \text { UFRJ } & \text { Universidade Federal do Rio de Janeiro } \\ \text { UFRN } & \text { Universidade Federal do Rio Grande do Norte } \\ \text { UFRR } & \text { Universidade Federal de Roraima } \\ \text { UFS } & \text { Universidade Federal de Sergipe } \\ \text { Ufsc } & \text { Universidade Federal de Santa Catarina } \\ \text { UFSM } & \text { Universidade Federal de Santa Maria } \\ \text { UFT } & \text { Universidade Federal do Tocantins } \\ \text { UFU } & \text { Universidade Federal de Uberlândia } \\ \text { UnB } & \text { Universidade Nacional de Brasília } \\ \text { Unicamp } & \text { Universidade Estadual de Campinas } \\ \text { Unifap } & \text { Universidade Federal do Amapá }\end{array}$




\section{LISTA DE GRÁFICOS}

Gráfico 2.1 - Esquema representativo da primeira seleção de produções científicas......

Gráfico 2.2 - Esquema representativo da primeira seleção de produções científicas organizada por base de dados....

Gráfico 5.1 - Editais de processos seletivos para formação de professores de Libras localizados entre 2006 a 2015.

Gráfico 5.2 - Ifes que ofertaram cursos para formação de professores de Libras entre 2006 a 2015 .....

Gráfico 5.3 - Quantidade de vagas ofertadas para formação de professores de Libras entre 2006 a 2015.

Gráfico 5.4 - Quantidade de vagas ofertadas nas modalidades EaD e presencial para formação de professores de Libras entre 2006 a 2015.

Gráfico 5.5 - Percentual de vagas ofertadas nas modalidades EaD e presencial para formação de professores de Libras entre 2006 a 2015.

Gráfico 5.6 - Total de vagas ofertadas em cursos de graduação para formação de professores de Libras entre 2006 a 2015.

Gráfico 5.7 - Quantidade de editais com seleção baseada na nota do Enem para ingresso em cursos de formação de professores de Libras entre 2006 a 2015.

Gráfico 5.8 - Percentual de editais que exigiram conhecimento em Libras nos processos seletivos para cursos de Letras Libras e Pedagogia bilíngue oferecidos entre 2006 a 2015.

Gráfico 5.9 - Quantitativo de editais que exigiram conhecimento em Libras nos processos seletivos para cursos de Letras Libras e Pedagogia bilíngue oferecidos entre 2006 a 2015.

Gráfico 5.10 - Percentual de editais disponibilizados em Libras nos processos seletivos para cursos de Letras Libras e Pedagogia bilíngue oferecidos entre 2006 a 2015.

Gráfico 5.11 - Comparação do total de editais disponibilizados em Libras e sem a Libras nos processos seletivos para cursos de Letras Libras e Pedagogia bilíngue oferecidos entre 2006 a 2015.

Gráfico 5.12 - Acessibilidade em Libras ofertada nos processos seletivos para cursos de Letras Libras e Pedagogia bilíngue oferecidos entre 2006 a 2015.

Gráfico 5.13 - Possibilidade de interposição de recursos à redação nos processos seletivos para cursos de Letras Libras e Pedagogia bilíngue oferecidos entre 2006 a 2015. 
Gráfico 5.14 - Percentual de medidas adotadas pelos editais para atribuir prioridade dos surdos em cursos de formação de professores de Libras entre 2006 a 2015.

Gráfico 5.15 - Evolução dos editais que acolheram ou não o critério de prioridade dos surdos em cursos de formação de professores de Libras entre 2006 a 2015.

Gráfico 5.16 - Percentual de reserva de vagas adotado pelos editais de processos seletivos para cursos de formação de professores de Libras entre 2006 a 2015.

Gráfico 5.17 - Representação dos editais com e sem reserva para PAA em processos seletivos para formação de professores de Libras localizados entre 2006 a 2015. 


\section{LISTA DE FIGURAS E MAPAS}

Figura 3.1 - Esquema representativo da noção de bilinguismo idealizado........... 82

Mapa 4.1 - Mapa representativo da distribuição de cursos de graduação para formação de professores de Libras distribuídos por estado com base nos dados extraídos do e-MEC (2015).................................... 104

Mapa 4.2 - Mapa representativo da distribuição de cursos de Letras com habilitação em Libras ofertados pela Ufsc com base nos dados extraídos do e-MEC (2015).......................................................... 105 


\section{LISTA DE TABELAS}

Tabela 4.1 - Relação de IES e cursos cadastrados no e-MEC voltados para a formação de professores de Libras....................................................... 103

Tabela 4.2 - $\quad$ Representação dos eixos, categorias e subcategorias de análise......... 115

Tabela 5.1 - Dados quantitativos de alunos do curso bilíngue de Pedagogia do Ines - 2006-2014 .......................................................................... 125

Tabela 5.2 - Distribuição das vagas do edital da UFPB (2009-2) para o processo seletivo de licenciatura em Letras Libras........................................... 129

Tabela 5.3 - Distribuição das vagas do edital da UFPB (2011-2) para o processo seletivo de licenciatura em Letras Libras.......................................... 129

Tabela 5.4 - $\quad$ Distribuição de editais disponíveis em Libras por Ifes....................... 153

Tabela 5.5 - Levantamento de população surda e ouvinte com educação superior no Brasil feito a partir de dados do IBGE de 2010 ............................. 201

Tabela 5.6 - Distribuição das vagas do edital da UFPR (2014-2) para o processo seletivo de licenciatura em Letras Libras............................................ 204

Tabela 5.7 - Distribuição de vagas do edital do IFG (2014-2) para o processo seletivo do curso de licenciatura em Letras Libras 
3 IMPLICAÇÕES DO DISCURSO DA DIFERENÇA NO CONTEXTO DA SURDEZ.

3.1 A LEITURA DO SURDO E DA SURDEZ SOB O PRISMA DA DIFERENÇA.

3.1.1 A diferença fora do discurso da diversidade. 57

3.1.2 Os estudos surdos. 59

3.2 REFLETINDO ACERCA DAS IDENTIDADES SURDAS E DAS MÚLTIPLAS CONDIÇÕES DE DESVANTAGEM

3.3 O SURDO NO CONTEXTO DA EDUCAÇÃO BILÍNGUE DE GRUPOS MINORITÁRIOS/MINORITARIZADOS.

3.3.1 Uma compreensão ampliada a respeito dos conceitos de língua e bi/multiliguismo.

3.3.2 Considerações sobre o contexto de ensino do português como L2 para surdos

3.3.3 Considerações sobre o contexto de ensino de Libras. 92

4.1 A ABORDAGEM QUALITATIVA. 96

4.2 A PESQUISA DOCUMENTAL E OS DOCUMENTOS COMO UMA VALIOSA FONTE DE INFORMAÇÕES.

4.3 O CONTEXTO DA PESQUISA

4.4 A GERAÇÃO DE DADOS 
5.1.1 O panorama da oferta de cursos de Letras Libras e Pedagogia bilíngue de 2006 a 2015

5.1.2 Organização da forma de ingresso adotada para os cursos de Letras Libras e Pedagogia bilíngue entre 2006 a 2015

5.1.3 Requisitos para o ingresso nos cursos de Letras Libras e Pedagogia bilíngue entre 2006 a 2015

5.1.3.1 A prova de conhecimentos em/sobre Libras.

5.2 CONDIÇÕES DE ACESSIBILIDADE

5.2.1 Editais traduzidos em Libras

5.2.2 Intérprete de Libras e/ou projeção da prova em Libras.

5.2.3 Tempo adicional

5.2.4 Uso do Aasi

5.2.5 Prova de Língua Portuguesa diferenciada.............................................. 169

5.2.5.1 Interposição de recursos à prova de redação..................................................... 172

5.2.6 Requisitos para obtenção do direito de acessibilidade e/ou prioridade.

5.3 A DISPOSIÇÃO DE VAGAS PARA SURDOS

5.3.1 A interpretação da prioridade dos candidatos surdos................................ 183

5.3.1.1 Preenchimento das vagas destinadas aos candidatos surdos........................... 192

5.3.2 Cruzamento entre a prioridade para surdos e a PAA ................................. 201

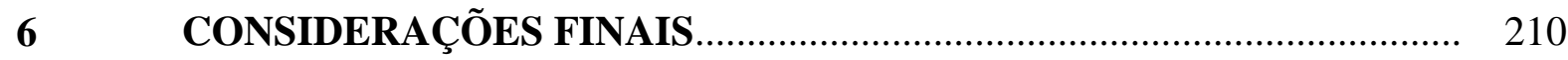

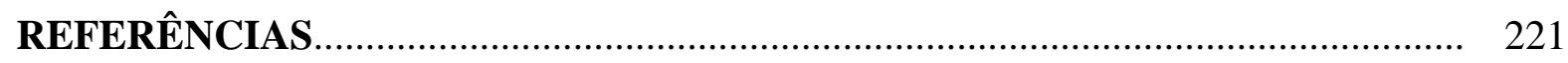




\section{INTRODUÇÃO}

A formação específica de professores de Língua brasileira de sinais (Libras) ${ }^{1}$ em cursos superiores trata-se de uma conquista recente na educação de surdos, embora, historicamente, o próprio direito à educação tenha sido tardiamente estendido às pessoas surdas ${ }^{2}$. Na verdade, o primeiro reconhecimento da cidadania desses sujeitos pela legislação ocorreu em 1000 a.C. com a Lei Hebraica (o Talmude), na Palestina, e em 529 d.C. com o Código de Justiniano, em Roma, quando as pessoas surdas passaram a ter "[...] direito à vida, mas, [...] não à educação." (COSTA, 2009, p. 20). Carvalho (2007, p. 9) descreve que esses documentos realizavam a distinção entre quem eram os "surdos e mudos" 3 " e aqueles que eram apenas surdos, pois aos que preservavam a capacidade da linguagem oral os direitos de possuir propriedades ou de se casarem estavam assegurados. Por outro lado, aqueles que eram vistos como "surdos e mudos" não cabiam direitos nem obrigações, e isso incluía o trabalho e a educação (CARVALHO, 2007).

De fato, até o final da Idade Média, os surdos eram considerados ineducáveis, pois a sociedade acreditava que a privação da linguagem oral, consequentemente, significava um impedimento para o desenvolvimento do pensamento (SACKS, 1998; CARVALHO, 2007; COSTA, 2009). Nas palavras de Sacks (1998, p. 27), até 1750, os surdos de diferentes nações viviam em condições subumanas, "[...] privados de alfabetização e instrução, de todo conhecimento do mundo, forçados a fazer os trabalhos mais desprezíveis, vivendo sozinhos muitas vezes à beira da miséria, considerados pela lei e pela sociedade como pouco mais do que imbecis $[\ldots] "$.

\footnotetext{
${ }^{1}$ Tal como Brito (2013), cabe destacar a possibilidade de encontrar na literatura autores como Thoma (2002, p. 14; 2006, p. 5), Pimenta e Quadros (2008, p. 66), Silva e Favorito (2009, p. 7), Gesser (2009, p. 10) e Lodi (2013, p. 165) que utilizam ou já utilizaram a sigla "LIBRAS", escrita integralmente em letras maiúsculas. Entretanto, observando os estudos mais recentes (THOMA; KLEIN, 2010; CHOI et al., 2011, p. 61; VILHALVA, 2012, p. 11; QUADROS; STUMPF, 2014, p. 9) já se denota a preferência pela grafia "Libras", com apenas a inicial maiúscula. Há ainda autores como McCleary $(2009$, p. 15) que optam pelo uso da sigla integralmente escrita em letras minúsculas "libras". Na presente pesquisa, adotamos a tendência mais recente da sigla Libras, em consonância com a grafia que consta na legislação que legitima tal sistema linguístico (BRASIL, 2002, 2005) e com as orientações gramaticais de Terra e Nicola Neto (1999) para o registro com apenas a inicial maiúscula, nas situações em que a sigla apresente mais de três letras e possa ser pronunciada como uma palavra.

${ }^{2}$ Enfatizamos que a redação introdutória não visa um aprofundamento histórico, apenas uma contextualização da formação de professores de Libras. Para uma leitura historiográfica acerca da educação de surdos no mundo e/ou no Brasil leia, por exemplo, Lane (1984), Carvalho (2007), Costa (2009), Sofiato (2011) e Brito (2013).

3 Por muito tempo o termo "surdo e mudo" foi utilizado para se referir às pessoas que apresentavam um comprometimento auditivo e, por consequência, não desenvolviam a língua oral de forma natural. Atualmente, sabe-se que a associação da surdez à mudez é inadequada, pois os surdos podem "falar" por meio da língua de sinais e muitos também se comunicam pela língua oral.
} 
Os primeiros profissionais a confiarem na possibilidade de os surdos serem educados surgiram no século XVI, no continente europeu ${ }^{4}$, mas ainda baseados em um ensino individual voltado, sobretudo, para os filhos de nobres que estavam preocupados em tornar seus primogênitos oralizados e, assim, garantir-lhes o direito à herança (LOPES, 2011; CARVALHO, 2007). Sob essa égide, para atender aos requisitos vigentes naquela época e tornarem os surdos reconhecidos legalmente como "capazes" de administrar os próprios bens, os educadores se empenhavam em ensiná-los a "[...] falar, ler, escrever, fazer contas, rezar, assistir à missa e confessar-se mediante o uso da palavra oralizada.” (LOPES, 2011, p. 41).

Naquele momento, alguns recursos foram criados para se ensinar os aprendizes surdos, tais como o alfabeto manual, os gestos e a leitura labial. Entretanto, para Lane (1984), o período entre 1764 a 1840 pode ser considerado a era dourada na educação de surdos, pois, conforme esse e outros autores (SACKS, 1998; MOURA, 2000; CARVALHO, 2007), foi quando os primeiros surdos passaram a ser educados pelo "método visual" do Abade Charles Michel de L'Epeé. Carvalho (2007) esclarece que a maior contribuição do clérigo e educador foi ter a sensibilidade de reconhecer e aprender essa língua de sinais utilizada pelos surdos nas ruas de Paris, construindo um sistema de ensino, denominado "sinais metódicos", pautando-se no uso dos sinais para a instrução da leitura e da escrita aos surdos (LANE, 1984; LOPES, 2011; REILY, 2004; CARVALHO, 2007). De acordo com Lopes (2011, p. 45):

O método de l'Épée consistia em ensinar sinais que correspondiam a objetos específicos e mostrar desenhos quando queria que os surdos compreendessem algumas ações, depois procurando associar o sinal com a palavra escrita em francês. Quando não havia um sinal para expressões abstratas, l'Épée buscava diretamente na visibilidade da escrita uma explicação.

No entanto, em consonância com Reily (2004), sem desmerecer o pioneirismo do referido educador, é importante salientar que os sinais metódicos de L'Epeé ainda seguiam palavra a palavra, baseados na gramática da língua oral francesa, desconhecendo a estrutura própria da língua de sinais. Apesar disso, são inegáveis as contribuições de L’Epeé para a época, pois diferentemente de outros educadores, que omitiam seus métodos, compartilhava-os com quem tivesse interesse, além de ter marcado a passagem da educação individual para o ensino

\footnotetext{
${ }^{4}$ De acordo com Carvalho (2007), na Idade Moderna, destacam-se na Espanha como os primeiros educadores de surdos Pedro Ponce de León e Pablo Bonet. Na Inglaterra, John Bulwer, John Wallis e Thomas Braidwood são mais conhecidos, sendo na Alemanha Samuel Heinicke e na França Charles Michel de L'Epeé e Jacob Rodrigues Pereira.

${ }^{5}$ Segundo Choi et al. (2011, p. 9), "o método visual baseia-se no uso dos gestos, dos sinais, do alfabeto manual e da escrita na educação dos surdos."
} 
coletivo de surdos ao criar a primeira escola pública do mundo no segmento, a qual serviu de modelo para outras centenas de escolas que seriam mais tarde fundadas na França e em outros países (LANE, 1984; REILY, 2004; CARVALHO, 2007).

Interessa destacar que o método visual de L'Epeé propiciou, com o tempo, a formação dos primeiros surdos como educadores de surdos. Sicard, que fora discípulo de L'Epeé, foi o instrutor de Jean Massieu, a quem Lane (1984) e Carvalho (2007) reconhecem ter sido a primeira pessoa surda a ocupar a profissão docente. Massieu lecionou no Instituto Nacional de Surdos-Mudos de Paris e, posteriormente, fundou uma escola em Lille, na França, foi professor e amigo do educador surdo Louis Laurent Marie Clerc, que acompanhado de Thomas Hopkins Gallaudet criaram, em 1817, a primeira escola para surdos dos Estados Unidos (LANE, 1984; MOURA, 2000; CARVALHO, 2007).

No Brasil, a história da educação de surdos também se originou com a participação de um surdo francês que, em 1855, chegou ao Rio de Janeiro com a intenção de abrir a primeira escola para surdos do país. E. Huet ${ }^{6}$, pupilo de Larent Clerc, iniciou em janeiro de 1856 o ensino a duas crianças surdas no Colégio de M. de Vassimon, local temporário onde permaneceu até ser transferido para o Imperial Instituto para Surdos-Mudos (BACELLAR, 2013/19267; SOFIATO, 2011). Segundo Bacellar (2013/1926), inicialmente, a escola de Huet encontrou dificuldades para conquistar os pais a entregarem a educação dos filhos surdos a um professor surdo estrangeiro e desconhecido, mas com o passar dos anos a instituição recebeu cada vez mais alunos, chegando à superlotação de mais de 300 internos, quando o regulamento preconizava um limite fixado de 35 alunos ${ }^{8}$.

De acordo com os registros históricos construídos por Bacellar (2013/1926), o colégio fundado por Huet, pode ser considerado a primeira escola no país dedicada ao ensino de surdos.

\footnotetext{
${ }^{6}$ Assim como referido por Sofiato (2011) e Choi et al. (2011), não há consenso a respeito do primeiro nome de Huet, se seria Hernest (LOPES, 2011), Ernest (COSTA, 2009), Ernesto (JANNUZZI, 1992), Edouard (SOFIATO, 2011) ou Edward (CHOI et al., 2011). Por essa razão, essas derivações são frequentemente localizadas na literatura da área. De acordo com informação verbal adquirida em visita feita por esta pesquisadora ao referido instituto, atualmente denominado como Instituto Nacional de Educação de Surdos (Ines), foi informado que o primeiro nome não consta em nenhum dos registros históricos dessa instituição, tendo esse educador sempre assinado como "E. Huet". Portanto, diante da incógnita, manter-se-á a escrita "E. Huet" ou simplesmente Huet.

${ }^{7}$ A tese de doutorado em medicina intitulada A surdo-mudez no Brasil (cadeira de hygiene) foi apresentada em 1926 e, por integrar o acervo histórico do Ines, foi republicada em 2013. Por considerarmos de suma relevância destacar a data desse documento histórico, sobretudo para se compreender o contexto e a linguagem utilizada pelo autor, adotamos como estratégia inserir, nesse caso, o ano de publicação do texto original seguido do ano em que tivemos acesso.

${ }^{8}$ Bacellar (2013/1926, p. 101, ipsis litteris), ao visitar a instituição em setembro de 1925, afirma ter se deparado com um cenário de "enorme desilusão". Sob uma administração e instalações precárias, o autor descreveu o instituto com "alunos maltrapilhos e descalços, recebendo instrução péssima, não por falta de professores ou incompetência deles, muito pelo contrario, mas por falta absoluta de material escolar - não ha papel, nem lápis, nem livros".
} 
Anos mais tarde, contando com a regência do professor surdo Manoel de Souza, foi fundado, também no Rio de Janeiro, o Instituto Central do Povo. Segundo o autor, esse estabelecimento de cunho filantrópico se tratava de um espaço de interação para os surdos ofertando não somente cursos de instrução secundária, bem como ensino religioso, esportes, assistência médica, odontológica, farmacêutica e jurídica.

Até a década de 1920, Bacellar (2013/1926) relata que, além dessas duas instituições cariocas, havia apenas outros dois locais destinados à escolarização de surdos no Brasil, sendo em Minas Gerais o "Asylo para moças surdas mudas de Itajubá”, o qual era dirigido por freiras de um convento, e que se restringia a ensinar-lhes serviços domésticos e alguns trabalhos manuais, com pouca ou nenhuma atenção à aquisição da leitura e escrita. Em São Paulo havia o Instituto Paulista de Surdos-Mudos Rodrigues Alves fundado, em 1911, pelo professor italiano Nicoláo Caruzone, um devotado defensor do método oral puro, cujo princípio se pautava pelo ensino da língua oral e, posteriormente, da língua escrita. Além disso, os adeptos desse método alegavam que o uso da datilologia (alfabeto manual) ou de sinais era prejudicial para a aprendizagem do surdo (CARVALHO, 2007).

Com efeito, o método oral passou a ser adotado não apenas em São Paulo, mas no Rio de Janeiro também, pois apesar do ensino de surdos ter, inicialmente, privilegiado a língua de sinais, por intermédio do professor surdo Huet, com o tempo, o Brasil foi influenciado por tendências internacionais advindas de orientações oralistas determinadas, sobretudo, após o II Congresso Internacional de Educação de Surdos, realizado em Milão, em 1880, mais conhecido como Congresso Internacional de Milão (LANE, 1984; CARVALHO, 2007; COSTA, 2009; BRITO, 2013). Nesse evento, educadores (somente os ouvintes) de surdos de diversas partes do mundo reuniram-se e votaram pelo método oral puro como a melhor abordagem educacional, tal decisão implicava a coibição do uso de qualquer comunicação manual. Moura (2000) e Sacks (1998) relatam que, a partir dessa data, a maioria dos professores surdos foi afastada de seus cargos, uma vez que o uso das línguas de sinais na educação de surdos passou a ser visto como nocivo aos seus aprendizes.

Nessa perspectiva, observa-se, assim, que o método visual pautado no uso da língua de sinais empoderou os surdos nos séculos XVIII e XIX, favorecendo sua escolarização a ponto de profissionalizá-los e torná-los responsáveis pela educação de seus pares. Contudo, em virtude da escolha por uma abordagem de ensino oralista, esses sujeitos foram destituídos da função docente e as consequências afetaram negativamente os surdos por quase cem anos. Ressalte-se que, no contexto desta tese, esse episódio histórico não pode ser negligenciado posto que se busca tratar do ingresso dos surdos na carreira docente. 
De acordo com Sacks (1998), anteriormente ao Congresso Internacional de Milão, em 1859, havia 550 educadores surdos no mundo, isto representava $50 \%$ dos professores atuando no segmento. Em 1960, esse quantitativo diminuiu para 12\%. Além disso, Carvalho (2007) afirma que, devido ao fraco desenvolvimento escolar dos surdos, resultante do insucesso do Oralismo, essas pessoas não conseguiam mais empregos nem eram capazes de estabelecer uma conversa profunda ou fluída com estranhos. Nesse viés, Costa (2009) e Bacellar (2013/1926) descrevem que a educação profissional dos surdos no Imperial Instituto para Surdos-Mudos, nas décadas de 1920 e 1930, no Brasil, privilegiava ofícios manuais como, por exemplo, a encadernação e a sapataria.

É válido pontuar ainda que, conforme narra Bacellar (2013/1926), durante esse período, os direitos dos surdos no Brasil estavam condicionados à comprovação de sua competência linguística na oralidade. Sem que pudessem se expressar pela escrita e pela "voz", as pessoas surdas estariam, perante a legislação vigente naquela época, impedidas de se unirem em matrimônio, prestarem serviços militares, serem testemunhas, atuarem no comércio ou redigirem testamento. Segundo o autor, conforme a Constituição Federal (CF) brasileira de 1891, que então vigorava, o indivíduo surdo teria seus direitos de cidadão suspensos até que pudesse se manifestar de modo considerado satisfatório para a sociedade ouvinte, pois se assim o fizesse comprovaria sua inteligência preservada para discernimento e adaptação ao meio social, mas, caso contrário, seria “[...] porque sofre de uma lesão central que o isola do mundo e o torna um alienado" (BACELLAR, 2013/1926, p. 127).

Nota-se, apesar do intervalo de dois mil anos, uma assustadora semelhança entre a legislação da década de 1920 no Brasil descrita por Bacellar (2013/1926) e o conteúdo da Lei Hebraica e do Código de Justiniano, que vigoravam na Antiguidade (CARVALHO, 2007), e, como já citados, foram os primeiros documentos legais da história voltados aos surdos e que imputavam a esses a exigência da capacidade de se exprimir pela linguagem oral para acessar direitos. Assim, no campo jurídico, é possível declarar que o avanço foi tímido até a primeira metade do século passado e que as principais conquistas estão, certamente, atreladas ao reconhecimento do estatuto linguístico das línguas de sinais, alcançado na década de 1960, e ao seu autorizado o retorno para a educação de surdos observado na década de 1980 com a Comunicação Total ${ }^{9}$.

\footnotetext{
${ }^{9}$ Conforme Paccini (2007), a Comunicação Total foi considerada no Brasil como uma filosofia educacional apoiada na língua falada oralmente, no alfabeto manual, no uso de sinais, imagens, apontamentos e na língua escrita. Segundo Albres (2005), apesar de se beneficiar dos sinais da Libras, seu uso era condicionado à estrutura da Língua Portuguesa, o que comprometia o desenvolvimento linguístico da Libras como um sistema linguístico.
} 
De acordo com Silva e Favorito (2009), após quase um século de fracasso escolar de alunos surdos na educação oralista, seu inevitável declínio conduziu ao surgimento de uma nova abordagem de ensino, a saber, a Comunicação Total, que, embora também não tenha logrado êxito no processo de escolarização dos alunos surdos, contribuiu para que o uso da língua de sinais fosse (re)aceito no espaço de educação formal para surdos ${ }^{10}$. Naquele mesmo período, fortaleceram-se os estudos sobre a descrição gramatical da língua de sinais em âmbito internacional, a partir do trabalho do linguista William Stokoe Jr. (1961 ${ }^{11}$ ) e, no cenário brasileiro, especialmente com as produções de Lucinda Ferreira-Brito (1986), Ronice Müller de Quadros (1997), Tânya A. Felipe (1997), Eulália Fernandes (2003), Lodenir Becker Karnopp (QUADROS; KARNOPP, 2004), entre outros.

Na década de 1980, autores como Rocha-Coutinho (1986) já advogavam pelo uso da língua de sinais no país, pautada em estudos internacionais que comprovavam que alunos surdos filhos de pais surdos, por desenvolverem a língua de sinais precocemente, exibiam melhor desempenho escolar, social e comunicativo comparado aos filhos surdos de famílias ouvintes, inclusive se as últimas apresentassem condições socioeconômicas e nível acadêmico mais elevados. Resultados semelhantes são expostos por Ferreira-Brito (1986, p. 20), ao destacar que pesquisas realizadas no município de Campinas, interior do estado de São Paulo, concluíram “[...] que os surdos, em período escolar, não sabem ler, interpretando apenas frases isoladas, na maioria dos casos, apesar de terem revelado, através de teste de inteligência, um desenvolvimento intelectual de nível acima da média”. As autoras defendiam o fim de uma cultura oralista, na educação de surdos apregoando o reconhecimento da língua de sinais e seus benefícios na aprendizagem dos alunos surdos.

Entretanto, a escassa formação de profissionais para ensino de surdos existente naquele tempo, conforme Vieira-Machado (2010), ainda estava voltada, predominantemente, para a educação oralista. Segundo essa autora, até a década de 1950, a única instituição formadora de educadores para atuarem no segmento era o Ines e seus cursos admitiam apenas um professor por estado brasileiro. Como essa demanda era insuficiente ${ }^{12}$, a autora relata que, em 1969, o estado do Espírito Santo criou um curso destinado ao atendimento de alunos surdos, coordenado

\footnotetext{
${ }^{10}$ Importa destacar que, conforme descrevem Silva e Favorito (2009) e Brito (2013), apesar da repressão ao uso das línguas de sinais, determinada após o Congresso Internacional de Milão, esta se manteve viva, transmitida por pais surdos aos filhos e veiculada às escondidas nos próprios espaços escolares repressores.

${ }^{11} \mathrm{Na}$ mesma época, Tervoort (1961), também desenvolvia, desde 1951, um estudo com crianças surdas de países como Holanda, Bélgica e Estados Unidos baseado em uma investigação psicolinguística para analisar o uso dos "gestos" para a comunicação de crianças surdas com seus familiares e educadores.

12 Albres (2005) relata que, na década de 1960, em virtude da inviabilidade de enviar todas as crianças surdas ao Ines, estas passaram a ser acolhidas por instituições como a Associação de Pais e Amigos dos Excepcionais e o Instituto Pestalozzi, criados em diversas regiões do país.
} 
pela professora Alpia Couto, cujas orientações se difundiram pelo país. Esse curso seguia as tendências oralistas vigentes, a referida professora criou uma cartilha intitulada Posso Falar, a qual se pautava no método oral puro, orientando os educadores a inibirem qualquer uso de sinais. Segundo Vieira-Machado (2010, p. 50),

[...] a formação do professor visava ensinar técnicas e métodos de ensino da fala oral, propagando, ainda, uma perspectiva clínica da surdez. O método era considerado "perfeito". Por isso, a ideia era de que, se o aluno fracassasse, a culpa seria do professor, que não soube aplicar o método corretamente, ou até mesmo do aluno surdo, que poderia ser considerado "preguiçoso".

Essa pedagogia oralista vigorava na educação de surdos, não apenas no Espírito Santo, de onde provém a narrativa da autora, mas, conforme Gesser (2012), há relatos de surdos em todo o país de que, durante sua experiência escolar, tinham as mãos amarradas como forma de a escola proibi-los de se comunicarem pela língua de sinais. Desse modo, durante muito tempo, a escola desempenhou o papel de "clínica de reparação", assumindo "[...] uma pedagogia da correção, da normalização do outro que é diferente.” (GESSER, 2012, p. 86).

De acordo com Albres (2005), a primeira proposta nacional para educação de surdos, divulgada pelo Ministério da Educação (MEC), em 1979, buscava cercear o uso da língua de sinais, alegando que restringia a expressar conceitos concretos e com uma organização gramatical prejudicial à aquisição da escrita. A autora complementa que, na década de 1990, o ensino da língua de sinais, ainda não oficializada no país, já começa a ser considerada pelas orientações do MEC, embora, o viés dos documentos ainda retratassem os professores especializados como técnicos e terapeutas da fala, cuja ação pedagógica, pautada na filosofia oralista, consistia, essencialmente, em promover a estimulação da leitura orofacial e o treinamento auditivo e da expressão oral.

Nessa direção, Vieira-Machado (2010) enfatiza que, até o ano 2000, a formação de professores capixabas para atuarem com a educação de surdos era integralmente baseada no Oralismo. A partir de então, os professores do Espírito Santo tiveram acesso ao conhecimento da Libras apresentada em um curso de formação no qual se reservava um módulo de 40 horas para denegrir o uso da língua de sinais. Segundo a autora, nesse curso ainda se difundia “"...] o lugar principal de erradicação da Língua de Sinais, lugar onde se aprendia todos os malefícios dela (da Libras) para as pessoas surdas.” (VIEIRA-MACHADO, 2010, p. 52).

Gesser (2012) e Vieira-Machado (2010) descrevem que, paulatinamente, mesmo alguns defensores da abordagem oralista começaram a perceber que o uso da Libras era inevitável para o êxito do desenvolvimento cognitivo e emocional dos aprendizes surdos, mas não se pode 
perder de vista que essa é uma mudança recente nesse contexto. De fato, somente após uma série de reivindicações fomentada pela organização do movimento social surdo brasileiro (BRITO, 2013), a legitimação da Libras sancionada em 2002, por meio da Lei no 10.436, de 24 de abril de 2002, também conhecida como Lei de Libras, consagrou a vitória das comunidades surdas $^{13}$. Entretanto, essa oficialização trouxe novos questionamentos como, por exemplo, o que fazer com as práticas pedagógicas oralistas e como repensar a formação de professores para o novo cenário que se desenhava (VIEIRA-MACHADO, 2010).

Nessa esteira, o Decreto $\mathrm{n}^{\circ}$ 5.626, de 22 de dezembro de 2005 (BRASIL, 2005), foi homologado com intuito de regulamentar a Lei $n^{\circ}$ 10.436/02 (BRASIL, 2002) e, dentre outras contribuições, serviu para ratificar o reconhecimento da Libras como um sistema linguístico genuíno, determinando seu uso e difusão no acesso à comunicação e à informação, além de referendar a almejada educação bilíngue destinada aos sujeitos surdos, seja por meio da inclusão da disciplina Libras nos cursos de licenciaturas e Fonoaudiologia, ou pela regulamentação e propositura da formação e atuação de intérpretes e tradutores ${ }^{14}$ de Libras e Língua Portuguesa e, também, de professores e instrutores de Libras.

Diante desse novo quadro, Vieira-Machado (2010, p. 62) relata que "a figura do professor especialista em deficiência auditiva passa a ser substituída pelo professor de Libras e pelo professor bilíngue, que aparecem no cenário tendo inclusive um curso superior para essa formação específica." Conforme Miorando (2006), os sujeitos surdos preocupados com a própria educação, nesse momento, começaram a buscar cursos de formação para docência da Libras e/ou uma certificação que os autorizassem a ensinar a própria língua nos mais diferentes espaços, sobretudo, na escola, pois, embora a Libras também tenha adentrado outras esferas da sociedade, é inegável que os espaços educacionais foram os mais influenciados. Além disso, como declara Quadros (2006a, p. 155), as proposições dos surdos sempre estiveram voltadas

\footnotetext{
${ }^{13} \mathrm{O}$ conceito de comunidades surdas no plural é utilizado em acordo com a visão socioantropológica da surdez de Skliar (2016) e que norteia o presente estudo. Neste sentido, os surdos são vistos como integrantes de grupos linguísticos minoritários/minoritarizados (CAVALCANTI, 1999), aproximando seus interesses aos de outros contextos minoritários/minoritarizados como indígenas, imigrantes, entre outros e os distanciando de visões patologizantes que buscam a normalização/reabilitação do surdo. Os surdos se unem em associações, congressos e outros eventos para produzir cultura(s) surda(s) (textos, poesias, literatura, teatro etc.), para se manifestarem sobre e na própria língua e sobre políticas educacionais e linguísticas em favor das pessoas surdas ou simplesmente para conversarem livremente através da língua de sinais, sem os esforços provenientes da oralidade. Cabe ressaltar ainda que existem várias comunidades surdas no Brasil e no mundo, sendo incoerente essencializar o conceito de comunidades surdas como comunidade única e homogênea (KUMADA, 2012).

${ }^{14}$ Segundo Pires e Nobre (2004), o ato de traduzir, seja nas línguas de sinais ou nas línguas orais, está relacionado à passagem de um texto escrito na língua-fonte para um texto escrito na língua-meta. Por outro lado, a interpretação está vinculada ao texto oral. De acordo com Quadros $(2004$, p. 11), o profissional que realiza a tradução e interpretação da língua de sinais para outra língua, seja na modalidade oral ou escrita (e vice-versa), é denominado "tradutor-intérprete de língua de sinais".
} 
para a defesa de uma “[...] escola pública de qualidade em língua de sinais, com professores bilíngues e professores surdos."

Era o início da transição na formação de professores de surdos para a formação de surdos como professores, pois ainda que pouco representativo, em termos estatísticos, nos anos subsequentes a Lei de Libras, os surdos passaram a concluir a educação básica (MANDELBLATT, 2014) e a educação superior (CHOI et al., 2011; THOMA; KLEIN, 2010). Na busca pela qualificação profissional, Lopes (2011, p. 25) aponta que a grande procura dos surdos foi pela carreira docente e pela pesquisa, principalmente, no campo da educação, pois "a luta era pela qualificação de um corpo de profissionais surdos capazes de servirem como referência para crianças e jovens surdos.”

No rastro desses ideais, as comunidades surdas do país elaboraram o documento intitulado A educação que nós surdos queremos (FEDERAÇÃO NACIONAL DE EDUCAÇÃO E INTEGRAÇÃO DE SURDOS, 1999), no qual enfatizavam a importância de se prever aos surdos a oferta de vagas como professores de Libras, recuperando assim o posto de educadores surdos (envolvidos com a escolarização de seus pares) que lhes fora subtraído após o já mencionado Congresso Internacional de Milão. Atendendo a essa reivindicação das comunidades surdas brasileiras, os artigos $4^{\circ}, 5^{\circ}$ e $7^{\circ}$ do Decreto ${ }^{\circ}$ 5.626/05 (BRASIL, 2005) estabelecem não apenas o direito de prioridade resguardado às pessoas surdas para o ingresso nos cursos de formação para docência da Libras, bem como para ministrarem a disciplina dessa língua. Essa garantia se alinha com as determinações promulgadas alguns anos mais tarde, por meio da Convenção Internacional sobre os Direitos das Pessoas com Deficiência (BRASIL, 2010), assinada em 30 de março de 2007, incorporada à legislação brasileira por meio do Decreto $\mathrm{n}^{0}$ 6.949, de 25 de agosto de 2009, em que alcança o status de emenda constitucional. A referida convenção delega aos Estados partes a responsabilidade de implementar "[...] as medidas apropriadas para empregar professores, inclusive professores com deficiência, habilitados para o ensino da língua de sinais [...]" (BRASIL, 2010, p. 48).

Diante do exposto, observa-se o incentivo por parte do ordenamento jurídico brasileiro (e internacional) a favor da atuação profissional de sujeitos surdos como professores de Libras, que devem, seguramente, habilitar-se para o serviço. Mas, como os surdos alcançariam essa habilitação para o ensino da Libras? Segundo Thoma e Klein (2010, p. 127), “hoje a Libras está sendo disseminada; em todo o país, cresce a demanda por professores de Libras, não apenas nos cursos em que a disciplina é obrigatória, mas em diversos cursos da área das ciências humanas, das ciências da saúde e até mesmo das ciências exatas", visto que a disciplina curricular de Libras também é prevista, no artigo $3^{\circ}$ do Decreto $n^{\circ}$ 5.626/05 (BRASIL, 2005), 
como optativa em todos os cursos de educação superior e educação profissional. O espaço para o ensino da Libras tem se ampliado na sociedade e são instituídos diferentes perfis profissionais, cada qual com sua respectiva formação e/ou certificação para atuar nos diversos contextos de educação formal e/ou não formal, sendo inclusive previsto um perfil provisório, até 2015, enquanto se aguardava a formação em cursos superiores desses docentes (BRASIL, 2005).

Logo, durante a última década, admitia-se como formação para o ensino da Libras desde o nível médio, cursos de graduação, pós-graduação até a autorização por exames de proficiência. Para dirimir sobre as questões envolvendo a formação e a atuação de cada um desses perfis profissionais, o citado decreto foi e ainda é utilizado como o principal documento no embasamento da formação e na orientação dos locais de atuação para os docentes da Libras. Portanto, cabe retomar o que tal instrumento normativo estabelece em seu artigo $4^{\circ}$ acerca da formação de professores para o ensino de Libras na educação formal:

Art. $4^{\circ} \mathrm{A}$ formação de docentes para o ensino de Libras nas séries finais do ensino fundamental, no ensino médio e na educação superior deve ser realizada em nível superior, em curso de graduação de licenciatura plena em Letras: Libras ou em Letras: Libras/Língua Portuguesa como segunda língua. Parágrafo único. As pessoas surdas terão prioridade nos cursos de formação previstos no caput.

Art. $5^{\circ} \mathrm{A}$ formação de docentes para o ensino de Libras na educação infantil e nos anos iniciais do ensino fundamental deve ser realizada em curso de Pedagogia ou curso normal superior, em que Libras e Língua Portuguesa escrita tenham constituído línguas de instrução, viabilizando a formação bilíngue.

$\S 1^{\circ}$ Admite-se como formação mínima de docentes para o ensino de Libras na educação infantil e nos anos iniciais do ensino fundamental, a formação ofertada em nível médio na modalidade normal, que viabilizar a formação bilíngue, referida no caput.

$\S 2^{\circ}$ As pessoas surdas terão prioridade nos cursos de formação previstos no caput. (BRASIL, 2005, p. 28, grifo nosso).

Com base no disposto desses artigos, evidenciam-se duas formações distintas de professores de Libras. A primeira é realizada por meio de cursos de licenciatura em Letras com habilitação em Libras ou em Libras/Língua Portuguesa como segunda língua (doravante Letras Libras), formando profissionais voltados à docência nos anos finais do ensino fundamental, ensino médio e educação superior. Uma segunda formação pode ser propiciada por meio da graduação em cursos de Pedagogia ou normal superior, ou cursos de nível médio na modalidade normal, viabilizados a partir de uma perspectiva bilíngue na qual a Libras e a Língua Portuguesa escrita tenham se constituído como as línguas de instrução. Os egressos de tais cursos de Pedagogia, normal superior ou normal nível médio são habilitados para docência de Libras na educação infantil e nos anos iniciais do ensino fundamental. 
Antes de nos atermos a cada uma dessas formações para a docência da Libras, cumpre informar o leitor que, prevendo a dificuldade de se encontrar, em curto prazo, os profissionais com a qualificação profissional exigida nos artigos $4^{\circ}$ e $5^{\circ}$ do Decreto $n^{\circ} 5.626 / 05$, uma vez que eram cursos praticamente inexistentes até então no país, e visando atender o seu $\S 2^{\circ}$ do artigo $7^{\mathrm{o}}$ no qual estipula que a partir de um ano da publicação do decreto "[...] os sistemas e as instituições de educação básica e superior devem incluir o professor de Libras em seu quadro do magistério" (BRASIL, 2005), o referido instrumento legal estabeleceu que:

Art. $7^{\circ}$ Nos próximos dez anos, a partir da publicação deste Decreto, caso não haja docente com título de pós-graduação ou de graduação em Libras para o ensino dessa disciplina em cursos de educação superior, ela poderá ser ministrada por profissionais que apresentem pelo menos um dos seguintes perfis:

I - professor de Libras, usuário dessa língua com curso de pós-graduação ou com formação superior e certificado de proficiência em Libras, obtido por meio de exame promovido pelo Ministério da Educação;

II - instrutor de Libras, usuário dessa língua com formação de nível médio e com certificado obtido por meio de exame de proficiência em Libras, promovido pelo Ministério da Educação;

III - professor ouvinte bilíngue: Libras - Língua Portuguesa, com pósgraduação ou formação superior e com certificado obtido por meio de exame de proficiência em Libras, promovido pelo Ministério da Educação.

$\S 1^{\circ}$ Nos casos previstos nos incisos I e II, as pessoas surdas terão prioridade para ministrar a disciplina de Libras. (BRASIL, 2005, p. 28, grifo nosso).

Desse modo, determinou-se que até 22 de dezembro de 2015, além dos cursos de Letras Libras, outros profissionais poderiam assumir a docência da Libras na educação superior, entre os quais estava inscrita a figura do instrutor de Libras. O papel do instrutor de Libras, segundo Faria (2011), gerou bastante polêmica, devido à falta de clareza do Decreto $n^{\circ}$ 5.626/05 em definir adequadamente quem é esse profissional e quais as suas atribuições, sendo, por isso, muitas vezes confundido com a figura do professor de Libras. Para dirimir eventuais dúvidas, revisitando tal documento legal, é possível identificar que a primeira diferença entre o professor e o instrutor de Libras reside na formação:

Art. $6^{\circ} \mathrm{A}$ formação de instrutor de Libras, em nível médio, deve ser realizada por meio de:

I - cursos de educação profissional;

II - cursos de formação continuada promovidos por instituições de ensino superior; e

III - cursos de formação continuada promovidos por instituições credenciadas por secretarias de educação.

$\S 1^{\circ}$ A formação do instrutor de Libras pode ser realizada também por organizações da sociedade civil representativa da comunidade surda, desde 
que o certificado seja convalidado por pelo menos uma das instituições referidas nos incisos II e III.

$\S 2^{\circ}$ As pessoas surdas terão prioridade nos cursos de formação previstos no caput. (BRASIL, 2005, p. 28, grifo nosso). ${ }^{15}$

Em face disso, o instrutor de Libras não precisa apresentar a formação de nível médio na modalidade normal ou um dos cursos superiores previstos nos artigos $4^{\circ}$ e $5^{\circ}$ do Decreto $n^{\circ}$ 5.626/05 (BRASIL, 2005). De fato, quando mencionado, em 1999, no documento A Educação que Nós Surdos Queremos (FEDERAÇÃO NACIONAL DE EDUCAÇÃO E INTEGRAÇÃO DE SURDOS, 1999), tal profissional foi descrito como aquele que, embora sem habilitação para o magistério, poderia ensinar a Libras para empresas, escolas e familiares de crianças surdas (FARIA, 2011). Segundo Albres (2014), essa foi uma forma de permitir que sujeitos surdos pudessem ensinar Libras, apesar de não possuírem a conclusão de um curso superior. Os poucos surdos com formação superior em Pedagogia ou em outra licenciatura (mesmo sem se constituírem como cursos direcionados à formação do professor de Libras), usualmente, foram denominados de professores de Libras, cabendo aos profissionais com ensino médio e cursos de capacitação de carga horária reduzida a denominação de instrutores de Libras.

Sob essa perspectiva, a Secretaria Municipal de Educação de São Paulo (SME/SP), na regulamentação da contratação e atuação dos profissionais instrutor e professor de Libras, definiu que a diferença residia na titulação, sendo caracterizado como professor o profissional graduado e como instrutor aquele que possui apenas o ensino médio (LACERDA; ALBRES; DRAGO, 2013). Assim, conforme essas autoras, o instrutor de Libras foi classificado como o profissional, preferencialmente surdo, “[...] com certificação mínima em nível médio e certificado de proficiência no uso e no ensino da Libras" (LACERDA; ALBRES; DRAGO, 2013, p. 75) e como por estas é relatado, na prática pedagógica as atribuições do instrutor de Libras e do professor bilíngue se distinguem, uma vez que:

O instrutor surdo será responsável por realizar atividades de formação em Libras para a comunidade escolar, incluindo aí os pais e familiares dos alunos surdos e ouvintes das turmas em que há alunos surdos incluídos (art. 11, $2^{\circ}$, da Portaria $n^{\circ}$ 5.707). Assim, os instrutores, preferencialmente surdos, têm tanto a tarefa de ensinar Libras para toda a comunidade escolar, quanto a de acompanhar e trabalhar colaborativamente com os professores bilíngues que

\footnotetext{
${ }^{15}$ De acordo com Albres (2014), por muito tempo a Federação Nacional de Educação e Integração de Surdos (Feneis) foi a única instituição a promover cursos de capacitação para instrutores de Libras, utilizando a fluência em Libras como pré-requisito indispensável para admissão em tais cursos. Em São Paulo, Albres (2014) informa que foram formados 68 instrutores, por meio dos cursos de capacitação oferecidos pela Feneis de São Paulo. Segundo a autora, vale destacar ainda o projeto do governo federal intitulado Programa Nacional de Apoio a Educação de Surdos, realizado em 2001, com o intuito de capacitar e formar instrutores de Libras.
} 
assumirão o componente curricular Libras em todos os anos do ensino fundamental ( $2^{\circ}$ ciclo). (LACERDA; ALBRES; DRAGO, 2013, p. 75).

Nesse contexto, o professor ou instrutor de Libras (a depender da formação) ficaria responsável pelo ensino da Libras à comunidade escolar (funcionários, familiares etc.) e o professor bilíngue ${ }^{16}$ seria o profissional a quem caberia à docência do componente curricular Libras, destinado aos alunos surdos. Segundo as autoras, para realizar essa docência, o professor da SME/SP deveria apresentar formação em nível de graduação ou pós-graduação lato sensu em Libras, certificação de proficiência na docência em Libras, ou ainda (na falta da formação exigida) experiência comprovada no ensino dessa língua (LACERDA; ALBRES; DRAGO, 2013).

Sob outro prisma, Quadros (2006a, p. 154) descreve que os instrutores de Libras “[...] são os profissionais que vão participar do processo de aquisição da língua de sinais pelos surdos", ou seja, são os responsáveis pelo ensino da Libras aos alunos $\operatorname{surdos}^{17}$. Complementarmente, o artigo 14 do Decreto $\mathrm{n}^{\circ}$ 5.626/05 institui que as escolas devem apresentar em seu quadro profissional o "professor de Libras ou instrutor de Libras" (BRASIL, 2005, p. 29), tornando possível a interpretação de que o instrutor poderia substituir o professor de Libras nas escolas. No entanto, em concordância com Faria (2011), as disposições do Decreto $n^{\circ} 5.626 / 05$ (BRASIL, 2005) não podem ser analisadas isoladamente, pois mesmo que tal instrumento legal confira aos instrutores com a habilitação a função docente, é preciso considerar o contexto no qual esse profissional encontra-se inserido.

Nessa premissa, é válido ponderar o que determina a Lei de Diretrizes e Bases da Educação Nacional (LDB) n 9.394, de 20 de dezembro de 1996:

Art. 62. A formação de docentes para atuar na educação básica far-se-á em nível superior, em curso de licenciatura, de graduação plena, em universidades e institutos superiores de educação, admitida, como formação mínima para o exercício do magistério na educação infantil e nos 5 (cinco) primeiros anos do ensino fundamental, a oferecida em nível médio na modalidade normal. (Redação dada pela Lei $\mathrm{n}^{\circ}$ 12.796, de 2013) (BRASIL, 1996).

\footnotetext{
16 Para Lacerda, Albres e Drago (2013), o professor bilíngue ainda não possui um conceito bem definido na literatura, mas é entendido como aquele profissional com fluência em Libras e com formação em curso superior de Pedagogia ou licenciatura específica que atue no ensino e aprendizagem de crianças surdas, no interior de escolas bilíngues.

17 Para Faria (2011), a denominação "instrutor" tem sido, muitas vezes, utilizada equivocadamente, associada a todo profissional surdo responsável pela docência da Libras. Nesse caso, independente de sua formação, quando surdo, esse profissional é visto como instrutor, e quando ouvinte denominado de professor. Para a autora, trata-se de uma desvalorização do profissional surdo, como uma forma de discriminação.
} 
O artigo 62 da LDB/96 (BRASIL, 1996) se alinha às determinações dos artigos $4^{\circ}$ e $5^{\circ}$ do Decreto $n^{\circ}$ 5.626/05 (BRASIL, 2005), isto é, de que a formação mínima para docentes da educação básica deve ser o nível médio na modalidade normal. Essa informação é validada no Parecer do Conselho Nacional de Educação (CNE) nº 15/2009 em que consta:

Se a instituição educacional, atuando no ensino regular, desejar contratar professores para o exercício da docência, os mesmos deverão ser devidamente habilitados, nos termos da LDB e das normas educacionais vigentes. $\mathrm{Na}$ educação escolar, caracterizada como tal no artigo $1^{\circ}$ da LDB, obviamente, só se admite a contratação de professores devidamente habilitados. (BRASIL, 2009a, p. 5).

Idêntica posição pode ser vislumbrada no Parecer do CNE nº 04/2000 ao tratar da formação dos professores e demais profissionais da educação infantil, no qual se assevera que todos "os professores das instituições de educação infantil públicas ou privadas, deverão possuir, pelo menos, o diploma de curso normal de formação de professores de nível médio [...]" (BRASIL, 2000, p. 9). Desse modo, o instrutor de Libras sendo um profissional sem a formação mínima exigida pela Lei $\mathrm{n}^{\circ}$ 9.394/96 (BRASIL, 1996), mesmo habilitado como docente, por cursos de capacitação ou por intermédio da aprovação em exame de proficiência em Libras, não poderia ser admitido como professor na educação básica. Acaso apresente a formação exigida, conforme esclarece Faria (2011), deixaria de ser denominado instrutor e passaria a fazer jus ao título de professor.

O instrutor de Libras consiste, portanto, no profissional que, até 22 de dezembro de 2015, poderia atuar na docência de Libras nos cursos de educação superior (mas não de educação básica), conforme artigo $7^{\circ}$ do Decreto $n^{\circ}$ 5.626/05 (BRASIL, 2005) e, também, nos cursos livres da educação não formal, pois a LDB/96 estabelece diretrizes sobre os processos de educação escolar, ou seja, de educação formal, porém, conforme corrobora o Parecer CNE $n^{\circ} 15 / 2009$ :

Para o exercício de atividades educacionais em cursos livres, de educação não formal, em instituições que não integram quaisquer dos sistemas de ensino previstos na LDB, não há essa obrigatoriedade [de formação mínima nos cursos normal de formação de professores de nível médio], a não ser que essa atuação se dê em regime de intercomplementaridade com uma instituição regular de educação, desenvolvendo atividades consideradas curriculares, no âmbito da educação escolar. (BRASIL, 2009a, p. 5).

Sendo assim, ao determinar a formação mínima para profissionais da educação formal, no Parecer do $\mathrm{CNE} \mathrm{n}^{\circ}$ 15/2009 está declarada a possibilidade de inúmeros profissionais, 
inclusive desprovido de habilitação para a docência, atuarem em diferentes ambientes educativos não formais, espaços onde não há necessidade de autorização e fiscalização do MEC. Nessa lógica, esses constituiriam os espaços de atuação do instrutor de Libras, além da educação superior cujo exercício lhes foi permitido "[...] caso não haja docente com título de pós-graduação ou de graduação em Libras para o ensino dessa disciplina [...]”, no prazo de até dez anos a partir da publicação do Decreto no 5.626/05 (BRASIL, 2005, p. 28). Como esse período já se findou, atualmente somente os profissionais que atendem a formação dos artigos $4^{\circ}$ e $5^{\circ}$ do aludido decreto poderiam exercer função docente de Libras na educação formal. Ademais, outro perfil profissional provisório previsto para lecionar a Libras na educação superior, embora sem os cursos de formação docente, consiste no sujeito com " [...] certificado obtido por meio de exame de proficiência em Libras, promovido pelo Ministério da Educação" (BRASIL, 2005, p. 28).

O exame nacional para Certificação de Proficiência no Uso e no Ensino de Libras e para Certificação de Proficiência na Tradução e Interpretação de Libras/Língua Portuguesa (Prolibras) reside em uma avaliação dividida em duas etapas, a primeira composta por questões objetivas de múltipla escolha realizadas em Libras e transmitidas em vídeo. Os candidatos aprovados na primeira fase avançam para a seguinte, a prova prática (INSTITUTO NACIONAL DE ESTUDOS E PESQUISAS EDUCACIONAIS ANÍSIO TEIXEIRA, 2011).

Em concordância com Albres (2014), apesar do Prolibras não representar uma formação, nesta última década, este foi valorizado socialmente como se equivalesse a um curso de formação para o ensino de Libras. A autora salienta que inúmeros processos seletivos e concursos públicos para a atuação de profissionais professor de Libras ou tradutor/intérprete de Libras têm equiparado o certificado do Prolibras como um certificado de formação. Acompanhando essa tendência, Albres (2014, p. 17) declara que "as pessoas que prestaram o exame Prolibras e foram aprovadas passam a colocar em seus currículos 'certificado pelo MEC' no campo da formação, 'Prolibras número X', como uma identidade profissional, como se fosse um registro profissional”. O Prolibras foi instituído pelo Decreto $n^{\circ}$ 5.626/05:

Art. $8^{\circ} \mathrm{O}$ exame de proficiência em Libras, referido no art. $7^{\circ}$, deve avaliar a fluência no uso, o conhecimento e a competência para o ensino dessa língua. $\S 1^{\circ} \mathrm{O}$ exame de proficiência em Libras deve ser promovido, anualmente, pelo Ministério da Educação e instituições de educação superior por ele credenciadas para essa finalidade.

$\S 2^{\circ}$ A certificação de proficiência em Libras habilitará o instrutor ou o professor para a função docente.

$\S 3^{\circ} \mathrm{O}$ exame de proficiência em Libras deve ser realizado por banca examinadora de amplo conhecimento em Libras, constituída por docentes 
surdos e linguistas de instituições de educação superior. (BRASIL, 2005, p. 28 , grifo nosso). ${ }^{18}$

Tendo em vista essa orientação legal, o exame passou a habilitar as pessoas surdas ou ouvintes com nível superior de escolaridade (independente da graduação ou área de formação) como professores de Libras, e aquelas com nível médio de escolaridade como instrutores de Libras (INSTITUTO NACIONAL DE ESTUDOS E PESQUISAS EDUCACIONAIS ANÍSIO TEIXEIRA, 2011). De acordo com as informações contidas no sítio eletrônico do Instituto Nacional de Estudos e Pesquisas Educacionais Anísio Teixeira (Inep) ${ }^{19}$, a certificação do Prolibras tem sido "[...] aceita por instituições superiores ou de educação básica como títulos que comprovam a competência no uso e no ensino de Libras ou na tradução e interpretação da língua de sinais.” (INSTITUTO NACIONAL DE ESTUDOS E PESQUISAS EDUCACIONAIS ANÍSIO TEIXEIRA 2011).

Alguns surdos preocupados com esse modo de autorização do ensino da Libras, como, por exemplo, a pesquisadora Müller (2009), descreve o surgimento de diversas interpretações equivocadas nas comunidades surdas, inclusive na sociedade como um todo, que não compreenderam que o Prolibras é uma certificação, diferente do processo formativo configurado pelos cursos de graduação em Letras Libras e pelos cursos bilíngues de Pedagogia. No cerne desse debate, o referido exame passou a ser alvo de várias críticas, por ser considerado uma política aligeirada de habilitação para a docência (e para a tradução e interpretação) da Libras (MÜLLER, 2009; ALBRES, 2014). Albres (2014) assinala que a certificação correspondeu a uma alternativa para atender a demanda imediata de profissionais para ensino da Libras e para a sua tradução e interpretação, entretanto, acredita ser uma proposta equivocada, pois “[...] embora qualquer falante bilíngue possua competência comunicativa nas línguas que domina, nem todo bilíngue possui competência para ensiná-la.” (ALBRES, 2014, p. 114).

Sob esse prisma, cumpre ressaltar que compactuamos com essas autoras, pois para adquirir a competência pedagógica no ensino de línguas, o profissional necessita de formação adequada com intuito de aprofundar não só seus conhecimentos no uso e interação da língua,

\footnotetext{
${ }^{18}$ Cabe salientar que o artigo 20 do Decreto $\mathrm{n}^{\circ}$ 5.626/05 (BRASIL, 2005) também regulamentou o exame de Proficiência em Tradução e Interpretação da Libras - Língua Portuguesa, realizado anualmente, nos dez anos conseguintes à data de publicação do referido decreto.

${ }^{19} \mathrm{O}$ Prolibras tem sido realizado pelo MEC e pelo Inep em parceria com instituições credenciadas pelo MEC. Desde a sua primeira edição em 2006 até a edição de 2015, as instituições escolhidas foram a Universidade federal de Santa Catarina (Ufsc) e o Ines (INSTITUTO NACIONAL DE ESTUDOS E PESQUISAS EDUCACIONAIS ANÍSIO TEIXEIRA, 2011; UNIVERSIDADE FEDERAL DE SANTA CATARINA, 2015; INSTITUTO NACIONAL DE EDUCAÇÃO DE SURDOS, 2015).
} 
bem como a reflexão e descrição sobre o código linguístico, ou seja, em atividades epilinguísticas e metalinguísticas, cujo domínio pode não ser suficientemente avaliado em uma prova prática com duração média de 20 minutos por participante. Essa também foi a opinião expressa pelos participantes surdos da pesquisa realizada por Müller (2009, p. 56), professores de Libras de cursos de educação superior que quando entrevistados declararam que "o Prolibras não qualifica apenas certifica.” Isso gerou uma apreensão por parte da autora, pois, em sua visão, os profissionais certificados, muitas vezes, não se encontram aptos para o ensino de línguas, embora tenham sido autorizados a ministrarem aulas de Libras na educação superior. De acordo com os professores surdos participantes de seu estudo, apesar de também terem requerido a certificação do Prolibras, buscaram a qualificação profissional para a docência da Libras, por intermédio de cursos de formação (MÜLLER, 2009).

Uma das possibilidades de habilitação para a docência da Libras estabelecida no artigo $7^{\circ}$ do Decreto $n^{\circ}$ 5.626/05 (BRASIL, 2005), vincula a formação para o ensino da Libras na educação superior a uma pós-graduação nessa área, determinando em seu artigo 12 que essas instituições, a partir de um ano da publicação do decreto, deveriam viabilizar cursos de pósgraduação para formar professores de Libras. No entanto, em concordância com Albres (2014), o mencionado decreto não esmiúça com clareza como devem ser organizados e ofertados tais cursos, se lato sensu ou stricto sensu. Com isso, abriram-se brechas para se questionar se um mestrado em Linguística ou em Linguística Aplicada envolvendo estudos sobre o ensino da língua de sinais poderia ser considerado como requisito para o ensino desse sistema linguístico ou se uma especialização abrangente em Libras seria suficiente. ${ }^{20}$ Para Albres (2014, p. 108):

A falta de critérios para seleção dos candidatos ao curso e a falta de pesquisa
no âmbito da linguística aplicada para conhecer o que se tem discutido sobre
a formação de professores e tradutores de línguas fez [sic] com que as grades
curriculares de cursos de pós-graduação lato sensu em Libras sofressem um
grande esvaziamento do que deveria ser uma formação consistente para um
especialista na língua. Como pode alguém matricular-se em uma pós-
graduação de Libras sem saber a língua? Será que cursando disciplinas 'Libras
1' e 'Libras 2', em cursos de final de semana durante um ano o aluno já teria
condições de ser denominado de especialista na língua? Pela falta de distinção
de habilitação na certificação esse "especialista" pode atuar no ensino ou na

\footnotetext{
${ }^{20}$ Imprimindo minha experiência como professora e membro de inúmeras bancas de defesa oral em cursos de pósgraduação lato sensu em Libras, considero válido destacar que diversos cursos deste segmento, geralmente, não exigem do aluno a comprovação da aptidão em Libras para o seu ingresso ou conclusão. Assim, muitas vezes, quando esse conhecimento não é ofertado durante a especialização em Libras, os alunos se formam (diplomados para a docência de Libras), sem, contudo, terem domínio nessa língua. Certamente, existem cursos envolvendo a pós-graduação stricto sensu que também não estipulam esse pré-requisito aos seus candidatos, o que, em virtude da falta de clareza do Decreto ${ }^{\circ}$ 5.626/05 (BRASIL, 2005) ou de outro documento legal nesse âmbito que forneça mais informações, gera dúvidas a respeito da formação apropriada em nível de pós-graduação.
} 
tradução/interpretação dessa língua? Conforme o Decreto $n^{\circ} 5.626$, de 22 de dezembro de 2005 a formação tanto do tradutor intérprete como do professor de Libras pode ser provida por curso de pós-graduação lato sensu.

Do ponto de vista dessa autora, tal como ocorre nas línguas orais, faz-se necessário que os cursos de pós-graduação em Libras sejam melhor direcionados para cada objetivo abrangendo o ensino da Libras sob os mais diversos aspectos, por exemplo, o ensino da Libras como segunda língua (L2), a metodologia do ensino da Libras, a gramática da língua, a teoria de aquisição de L2 etc. Além disso, importa lembrar que esse curso de pós-graduação, no tocante à educação formal, habilita somente para o ensino em cursos superiores. Portanto, a alternativa para a docência da Libras na educação básica se funda em apresentar a formação inicial, conforme estabelecido no Decreto no 5.626/05 (BRASIL, 2005), seja em nível médio ou superior.

O curso normal de formação de professores de nível médio previsto pelo Decreto $\mathrm{n}^{\circ}$ 5.626/05 (BRASIL, 2005) e pela LDB/96 (BRASIL, 1996) como formação mínima para exercer a docência na educação infantil e nos anos iniciais do ensino fundamental, diz respeito a um curso bastante comum há algumas décadas, frequentemente, conhecido como magistério. Contudo, cursos do segmento foram drasticamente reduzidos em decorrência da determinação do $\S 4^{\circ}$ do artigo 87 (Das disposições transitórias), no qual foi instituído que até o final da década da educação (período de dez anos a partir da publicação da LDB/96) somente seriam admitidos professores habilitados em nível superior ou formados por treinamento em serviço (BRASIL, 1996). Cabe ainda destacar que tal parágrafo foi revogado pela Lei $\mathrm{n}^{\circ} 12.796$, de 4 de abril de 2013 (BRASIL, 2013a), porém o Decreto $n^{\circ}$ 5.626/05 foi publicado durante esse período da chamada década da educação. Por esse motivo, conforme Faria (2011), foi necessário prever a formação de professores em curso normal de nível médio, embora estes não sejam mais facilmente localizados.

Além disso, o Decreto $\mathrm{n}^{\circ}$ 5.626/05 (BRASIL, 2005) estabelece que para serem aceitos como formação para docência de Libras, tais cursos devem ter sido viabilizados sob uma perspectiva bilíngue, mediante o uso da Libras e da Língua Portuguesa em sua modalidade escrita como línguas de instrução.

Atendendo essas exigências, em nosso levantamento da literatura da área, encontramos informações dessa proposta de curso de magistério bilíngue, oferecido apenas na Escola Estadual de Educação Especial Doutor Reinaldo F. Coser, em Santa Maria, no estado do Rio Grande do Sul. Segundo Scremin (2012), a criação dessa escola, em 2001, representou uma conquista das comunidades surdas e de professores surdos de Santa Maria, factível graças à 
parceria entre o município e o estado. A autora descreve que a abertura da referida instituição propiciou um espaço bilíngue para surdos desde a educação infantil, passando pelo ensino fundamental, educação de jovens e adultos até o curso de nível médio com habilitação para o magistério. O curso de magistério, conforme Scremin (2012), foi inaugurado, em 2006, logo após a publicação do Decreto nº 5.626/05 (BRASIL, 2005).

Desse modo, provavelmente, em virtude da década da educação, observamos que a formação de professores de Libras voltados ao trabalho na educação básica se deu, majoritariamente, por cursos de educação superior, que, como mencionado anteriormente, é determinado pelo Decreto $n^{\circ}$ 5.626/05 (BRASIL, 2005) que ocorra por meio de cursos bilíngues de Pedagogia ou normal superior, ou ainda pelo curso de licenciatura em Letras Libras ${ }^{21}$.

Nesse cenário, o primeiro curso do país a atender tais requisitos foi o curso de Pedagogia ofertado na modalidade de Educação a distância (EaD) adaptado para surdos da Universidade do Estado de Santa Catarina (Udesc). Segundo Costa et al. (2005) e Quadros (2006a), o curso foi oferecido antes do aludido decreto (BRASIL, 2005), em 2002, no município de Florianópolis, para uma turma de 32 alunos surdos e sete ouvintes que atuavam com alunos surdos em outras instituições. Além da adaptação curricular (com disciplinas específicas como Libras, história dos surdos, português instrumental, entre outras) e dos processos avaliativos (que permitiam utilizar a escrita ou o registro em filmagem), o curso dispunha de tutores bilíngues, vídeos pedagógicos em Libras (ou com tradução simultânea), encontros presenciais semanais em Libras etc. (COSTA et al., 2005).

Na sequência dos primeiros cursos de graduação voltados à formação de professores de Libras encontram-se, em 2006, a criação do curso bilíngue de Pedagogia ${ }^{22}$ do Ines, oferecido no Rio de Janeiro, na modalidade presencial, sendo aberto processo seletivo anual para duas turmas de 30 alunos cada e o curso de Letras Libras da Ufsc que, conforme Quadros e Stumpf (2014), por se tratar de um curso de modalidade $\mathrm{EaD}$, ofereceu já em sua primeira turma 500

\footnotetext{
${ }^{21}$ É válido pontuar que os cursos de graduação de Letras Libras podem ser ofertados como cursos de bacharelado e licenciatura, conforme determinam os Referenciais Curriculares Nacionais dos Cursos de Bacharelado e Licenciatura, desenvolvidos pelo MEC (BRASIL, 2010b). Entretanto, de acordo com tais referenciais, o bacharel em Letras - língua estrangeira é aquele que elabora e executa trabalhos de revisão, tradução e pesquisa, podendo atuar em editoras, empresas de meios de comunicação, eventos, consulados e embaixadas, entre outros. Por outro lado, o licenciado em Letras - língua estrangeira é o professor, cuja atuação se volta, essencialmente, para o ensino da língua estrangeira, seja como professor em instituições de educação em nível fundamental e médio, na produção de materiais didáticos para o ensino presencial ou a distância, e em espaços de pesquisas educacionais (BRASIL, 2010b).

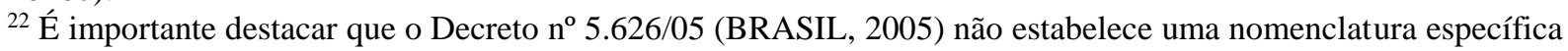
para o curso de Pedagogia ofertado em uma perspectiva bilíngue. Por essa razão, é possível encontrar duas denominações nessa área: "curso bilíngue de Pedagogia" e "Pedagogia bilíngue". Assim, utilizaremos ambas sem distinção, sempre buscando respeitar o termo adotado pela Instituição de Educação Superior (IES).
} 
vagas, preenchidas por 447 estudantes surdos e 53 ouvintes. Na segunda turma, em 2008, foram mais mil vagas. Decerto, outros cursos de graduação foram ofertados no país, embora, para Lacerda, Albres e Drago (2013), tanto o curso Letras Libras como a formação bilíngue em Pedagogia ou normal superior são ainda numericamente pouco expressivos no cenário da educação superior brasileira, pois:

[...] o curso de Letras/Libras, ainda bastante recente no país, foi oferecido na modalidade a distância em quinze polos em 2008 e em vinte polos em 2010 [sic], com turmas de cinquenta alunos em cada um dos polos espalhados pelo Brasil. Em São Paulo, formaram-se quarenta pessoas em 2010, o que certamente constitui um número insuficiente para atender às demandas de ensino das redes municipais, estaduais e de ensino superior que se estão consolidando na perspectiva de uma educação bilíngue e considerando alunos surdos. Alguns novos cursos presenciais estão sendo organizados e oferecidos, mas o conjunto de vagas ainda é tímido perto da necessidade real da área. (LACERDA; ALBRES; DRAGO, 2013, p. 74).

Diante do exposto, é possível observar como um novo cenário se desenhou na educação de surdos a partir da Lei $n^{\circ}$ 10.436/02 (BRASIL, 2002) e do Decreto $n^{\circ}$ 5.626/05 (BRASIL, 2005), e para atender a essa demanda foi requerida uma formação docente quase inexistente até então e que, aparentemente, conforme destacado por Lacerda, Albres e Drago (2013), ainda representa no país um quantitativo ínfimo em relação às exigências da nossa realidade. $\mathrm{Na}$ verdade, o cenário parece alarmante, porquanto após anos de submissão da educação de surdos a uma abordagem oralista que os impedia de serem instruídos por meio da língua de sinais e de se tornarem educadores, as comunidades surdas, finalmente, conquistam o direito de uma educação bilíngue. No entanto, com isso surgem inúmeros desafios, entre os quais, a formação de novos profissionais docentes para atuarem sob a égide do bilinguismo. Como exposto até aqui, dentre os perfis docentes estabelecidos pelos documentos legais (BRASIL, 2002, 2005), os instrutores de Libras não estão autorizados para o ensino dessa língua no âmbito da educação formal (FARIA, 2011), o período de admissão dos perfis profissionais provisórios já se findou, os cursos de pós-graduação em Libras recebem críticas por não terem uma definição explícita de seu currículo e segmento (ALBRES, 2014), os certificados do Prolibras também são malvistos, por serem considerados uma política aligeirada que não asseguram a formação e, consequentemente, a qualidade dos profissionais docentes. Por sua vez, o curso de nível médio para o magistério desenvolvido sob uma perspectiva bilíngue representa um quantitativo praticamente inexpressivo. 
Logo, embora os cursos de graduação de Letras Libras e Pedagogia bilíngue representem um número insuficiente para atender a demanda nacional, torna-se flagrante a urgência de investigá-los e de trazer reflexões e contribuições para esse processo tão recente no Brasil. Julgamos pertinente ainda que, reconhecendo o histórico de lutas das pessoas surdas e a importância da participação delas no percurso da educação de seu grupo, seja atribuído um olhar especial para o acesso dos surdos a esses cursos.

Com esse panorama em mãos, trazemos para esse trabalho a preocupação com esse contexto e, portanto, estabelecemos como objetivo geral investigar e analisar o acesso dos surdos a cursos superiores de formação de professores de Libras em instituições federais. Para atender a tal propósito, construímos os seguintes objetivos específicos: a) realizar um levantamento de cursos de Pedagogia bilíngue e Letras Libras ofertados no país na última década; b) traçar uma caracterização dos processos seletivos (vestibulares) envolvendo os cursos de Letras Libras e Pedagogia bilíngue realizados pelas Instituições Federais de Educação Superior (Ifes); c) analisar as condições de acessibilidade disponibilizadas pelas Ifes aos candidatos surdos durante os vestibulares envolvendo os cursos de Letras Libras e Pedagogia bilíngue; d) identificar e discutir a disposição de vagas ofertadas pelas Ifes nos cursos de Letras Libras e Pedagogia bilíngue para surdos.

A partir dos objetivos expostos, redigimos o presente relatório em seis capítulos. No capítulo introdutório buscamos, brevemente, narrar o percurso histórico trilhado pelos surdos, evidenciando seus inúmeros desafios para conquistarem o direito à educação, à educação por meio da língua de sinais e o direito de se tornarem educadores. Mostramos que, a duras penas, os surdos brasileiros alcançaram a legitimação da Libras e isso proporcionou um novo panorama, com a exigência de novos profissionais para a escolarização de aprendizes surdos sob uma perspectiva bilíngue, sendo um desses profissionais o professor de Libras. Discorremos ainda sobre o perfil de formação e atuação desse docente em Libras e, tendo essa discussão como pano de fundo, desvelamos a pertinência de nossa pesquisa compartilhando os objetivos geral e específicos.

Com os objetivos em mente, buscamos na literatura acumulada o que já fora produzido sobre o tema. Assim, o Capítulo 2 foi dedicado à apresentação da revisão bibliográfica, etapa na qual compartilhamos os procedimentos e os resultados do levantamento sistemático de dissertações, teses e artigos, exercício que permitiu a identificação de produções com aproximações e distanciamentos da nossa pesquisa.

No Capítulo 3 manifestamos nosso posicionamento teórico, por meio da afirmação da surdez como diferença, identificando quais as implicações desse discurso no âmbito dos estudos 
linguísticos, educacionais e de identidades. Para isso, procuramos situar nosso trabalho em Educação Especial sob um constante diálogo com a literatura dos Estudos Surdos, dos Estudos Culturais e da Linguística Aplicada.

No Capítulo 4 não apenas refletimos acerca da pesquisa qualitativa como abordagem teórico-metodológica pela qual nos guiamos, bem como discorremos a respeito da pesquisa com fontes documentais e a análise de conteúdo. Ainda no quarto capítulo, caracterizamos nosso contexto de pesquisa, isto é, o montante de instituições e de ofertas de cursos de graduação voltados à formação de professores de Libras no país, identificando qual recorte desse universo foi adotado no presente estudo.

O Capítulo 5 se destina à análise e discussão dos resultados da pesquisa envolvendo 80 editais de processos seletivos de Ifes nos quais cursos de graduação de licenciatura de Letras Libras e de Pedagogia bilíngue foram ofertados entre o período de 2006 a maio de 2015, recorte temporal estabelecido neste estudo. Para a apresentação da análise de conteúdo realizada, elencamos três eixos, a saber: 1) caracterização dos processos seletivos; 2) condições de acessibilidade; e 3) a disposição de vagas para surdos.

O fechamento desse percurso nos conduziu à redação do Capítulo 6, no qual tecemos algumas considerações finais, cientes de que nosso processo de pesquisa não esgota a temática, mas, em virtude dos passos trilhados até aqui, permitem-nos inferir algumas hipóteses e previsões. 


\section{REVISÃO BIBLIOGRÁFICA}

A revisão bibliográfica, como denominada por Deslauriers e Kérisit (2008, p. 134), consiste em uma prática que "[...] se funda sobre uma concepção do conhecimento considerado cumulativo, segundo o qual o progresso de um serve de ponto de partida para o outro." Em concordância com os autores, durante o delineamento da pesquisa, esta se constituiu como uma etapa primordial, especialmente para a construção do objeto de pesquisa, uma vez que se debruçar sobre a produção acadêmica existente permitiu realizar inferências sobre o que ainda não foi respondido, requisito basilar para a garantia da originalidade do estudo.

Neste aspecto, com o intuito de desvelar as produções teóricas concernentes ao acesso do surdo aos cursos superiores de formação de professores de Libras em instituições federais, realizamos um levantamento de produções científicas a partir do uso isolado e combinado de palavras-chave, a saber: 1) educação de surdos educação superior; 2) educação superior surdez; 3) educação superior deficiência auditiva; 4) educação superior deficiente auditivo; 5) ensino superior surdos; 6) formação de professores instrutores de Libras; 7) formação de instrutores de Libras; 8) formação de professores de Libras; 9) professores de Libras; 10) professores de língua brasileira de sinais; 11) curso bilíngue de Pedagogia; e 12) Letras Libras.

A consulta pelas palavras-chave abrangeu a busca por: 1) produções disponíveis no Portal de Periódicos da Coordenação de Aperfeiçoamento de Pessoal de Nível Superior (Capes) e na base de dados do Scientific Eletronic Library Online (SciELO); e 2) dissertações e teses disponíveis no Banco de Teses e Dissertações da Capes (BTDC) e na Biblioteca digital brasileira de teses e dissertações (BDTD).

Em um primeiro levantamento encontraram-se 1.328 produções (entre artigos, dissertações e teses) cuja leitura dos metadados (título, palavras-chave e resumo) permitiu desprezar 1.273 estudos que acusaram incompatibilidade com a temática ou a repetição de uma produção científica em diferentes bases. Assim, é possível afirmar que em uma primeira análise da revisão bibliográfica, foram selecionados 55 estudos, conforme representado no Gráfico 2.1.

Gráfico 2.1 - Esquema representativo da primeira seleção de produções científicas

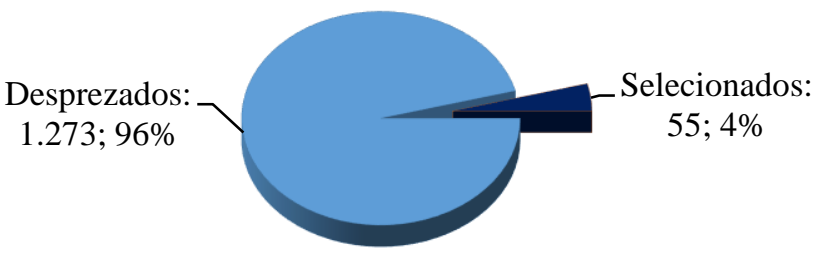


Dentre as 55 produções científicas inicialmente elegidas, 11 periódicos foram extraídos do Portal de Periódicos da Capes e três provieram da Base de Dados do SciELO. Complementarmente, entre as oito teses de doutorado e 33 dissertações de mestrado préselecionadas, 21 obras resultaram da consulta ao BTDC e 20 da consulta à BDTD, conforme projetado no Gráfico 2.2.

Gráfico 2.2 - Esquema representativo da primeira seleção de produções científicas organizada por base de dados

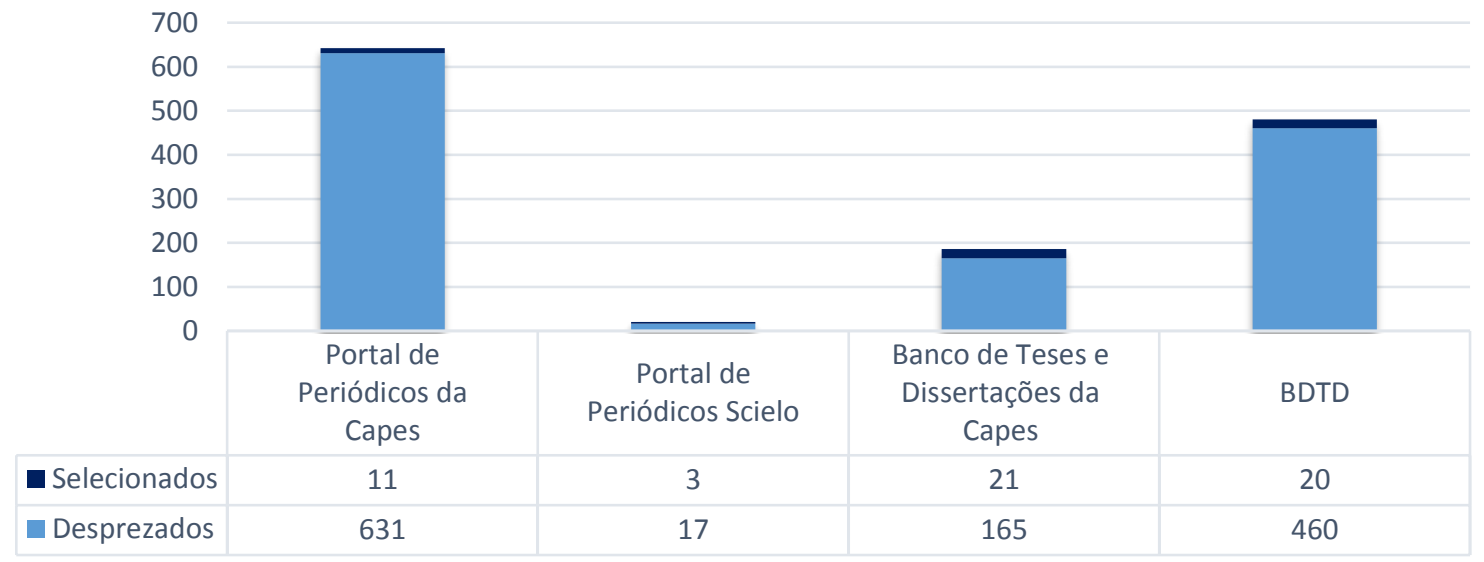

Os 55 trabalhos selecionados passaram por uma leitura parcial ${ }^{23}$ ou integral com o fito de identificar debates que apresentam proximidade com o objeto da presente pesquisa ou possível aproveitamento dessa literatura para a discussão dos dados.

No conjunto de obras analisado, a maior recorrência foi verificada nas 23 produções que abordaram o sujeito surdo na educação superior, porém sem correlação com a formação para a docência da Libras. Assim, localizamos 16 dissertações, três teses e quatro artigos contemplando a presença de aprendizes surdos na educação superior, seja com ênfase nos desafios envolvendo a produção escrita de acadêmicos surdos (SILVEIRA, 2007; NASCIMENTO, 2008; LINS, 2011; PERSE, 2011; CHAVES, 2012), seja na vivência do surdo nesse nível de ensino, trabalhada especialmente sob a perspectiva da história ou trajetória de

\footnotetext{
${ }^{23}$ Estamos denominando de leitura parcial, quando a leitura realizada não se estendeu sobre todo o material, mas apenas a algumas partes. Neste sentido, todas as obras tiveram o resumo, o sumário e a conclusão lidos. A partir disso, identificávamos se os trabalhos tinham proximidade com nosso tema, e quando verificávamos a existência de capítulo(s) que poderiam agregar informação a nossa discussão, procedíamos com a leitura desse(s) capítulo(s). Por outro lado, a partir da leitura parcial, quando constatado que a produção demonstrava correlação com nossa temática, realizávamos a leitura integral.
} 
vida dos alunos surdos (CONTIERI, 2007; PIRES, E. 2008; CRUZ; DIAS, 2009; DAROQUE, 2011; NANTES, 2012; ANDRADE, 2012; CASTRO, 2012; LAMB, 2013), ou pelo viés das políticas educacionais (SCHUBERT, 2012). Houve ainda estudos que se concentraram na presença do sujeito surdo na educação superior a partir da análise do uso ou contribuições de tecnologias ou da sua acessibilidade aos ambientes digitais, tal como a dissertação de Schneider (2012) e o artigo de Amorim e Silva (2009). Além disso, com maior proximidade aos nossos interesses, localizamos sete produções que se dedicaram a investigar o acesso ou o processo de inclusão de alunos surdos nesse nível de ensino (MANENTE; RODRIGUES; PALAMIN, 2007; BISOL et al., 2010; BARBOSA, 2011; PATRICIO, 2011; LIMA, 2012; NOGUEIRA, 2012; MESQUITA, 2013). Por essa razão, julgamos ser oportuno nos ater um pouco mais sobre estes.

Bisol et al. (2010), no artigo intitulado Estudantes surdos no ensino superior: reflexões sobre a inclusão, visaram conhecer a vivência de universitários surdos que haviam sido educados em escolas especiais bilíngues e, em virtude disso, construíram um processo de identificação e pertencimento à cultura surda. Os participantes surdos entrevistados são alunos da educação superior oriundos de instituições de ensino, majoritariamente, constituídas por alunos e profissionais ouvintes. Os resultados da pesquisa denotaram três desafios como sendo mais significativos e recorrentes nos depoimentos dos universitários surdos. O primeiro faz referência à exigência de situar a identidade surda no ambiente acadêmico, tradicionalmente habitado por ouvintes. Essa ação se deve à recorrente necessidade de se reafirmar a surdez, não como patologia, mas como um contexto característico de minorias linguísticas, isso porque, em geral, conforme os autores averiguaram, os professores e colegas ouvintes, por desconhecimento, privavam os alunos surdos de diversas situações de interação. Um segundo desafio denotado nesse estudo reside na presença e competência do intérprete e tradutor de Libras, pois na ausência deste, o surdo tende a ser ainda mais isolado. Segundo os resultados gerados por Bisol et al. (2010), a interação e o contato visual direto com o professor também diminuem na universidade, pois os docentes desconhecem a Libras e, muitas vezes, o intérprete não possui bagagem teórica ou técnica suficiente na área para traduzir todos os conteúdos ministrados. Por último, uma terceira categoria de análise registrada pelos autores, refere-se às dificuldades dos universitários surdos com a leitura e escrita de textos acadêmicos. Os autores destacam que, devido ao desconhecimento dos professores, a escrita particular do aluno surdo tende a ser incompreendida nesse contexto. Assim, ao cotejar o ensino bilíngue frequentado pelos jovens surdos na educação básica com a educação superior, os alunos percebem diversas 
perdas, o que os leva a idealizar uma universidade bilíngue, com professores e alunos surdos fluentes em Libras (BISOL et al., 2010).

Um passo atrás da vivência do aluno surdo na educação superior está o acesso a essa etapa. Nesse âmbito, cabe destacar a dissertação de mestrado elaborada por Lima (2012), cujo objetivo foi analisar $O$ acesso e permanência de indivíduos surdos no ensino superior. A pesquisa envolveu a participação da supervisora do setor responsável pelo vestibular, da coordenadora e dos professores do curso de pedagogia de uma universidade privada do município de São Paulo. Portanto, diferente do estudo de Bisol et al. (2010), a participação dos alunos surdos não foi diretamente contemplada. Lima (2012) avaliou desde o processo de ingresso dos alunos, ou seja, como se deu a seleção dos candidatos até a sua permanência na instituição de ensino. Logo, na avaliação do vestibular, a autora observou que a instituição desclassificou duas candidatas em decorrência de uma escrita fragilizada, marcada por ser um texto desconexo do ponto de vista sintático. Ainda que a instituição tenha afirmado que a sintaxe não constituiria um critério classificatório no processo seletivo, a análise de Lima (2012) demonstrou o contrário. Em relação à permanência na educação superior, novamente foi discutida a problemática da falta de domínio da escrita por alunos surdos, sobretudo, aqueles não oralizados. De acordo com a autora, para os professores entrevistados, a compreensão de textos e a escrita confusa e sem conectivos representam uma barreira significativa no aprendizado dos universitários surdos (LIMA, 2012).

Nesse viés, focalizando a escrita particular de aprendizes surdos, a dissertação de Barbosa (2011) O mecanismo da coerência na produção escrita de surdos: foco no vestibular 2011 da UFS teve por fito analisar os elementos de coesão presentes em 14 redações de vestibulares produzidas por candidatos surdos do processo seletivo de 2011 da Universidade Federal de Sergipe (UFS), sob uma reflexão das particularidades que envolvem o processo de escrita por sujeitos surdos usuários da Libras. Os resultados apontaram dificuldades, sobretudo, na flexão verbal, na ordem ortográfica e no emprego adequado do gênero, de verbos de ligação, preposições e conjunções. A autora conclui que se trata de interferências naturais a um aprendiz de Língua Portuguesa como L2, mas considera necessário problematizar como esse resultado pode se inter-relacionar com o fato de, tradicionalmente, as metodologias adotadas com escolares surdos corresponderem, muitas vezes, à mesma metodologia de ensino de língua materna acompanhada pelos discentes ouvintes.

No entanto, os desafios para o ingresso e a permanência na educação superior, aparentemente, não afligem apenas os surdos usuários da Libras, pois Manente, Rodrigues e Palamin (2007) no artigo intitulado Deficientes auditivos e escolaridade: fatores diferenciais 
que possibilitam o acesso ao ensino superior, ao realizarem uma investigação em "69 pacientes do Centro dos Distúrbios da Audição, Linguagem e Visão, do Hospital de Reabilitação de Anomalias Craniofaciais, da Universidade de São Paulo, em Bauru/SP (DEDALVI/HRAC/USP)” (MANENTE; RODRIGUES; PALAMIN, 2007, p. 30), sendo a maioria dos participantes surdos oralizados, constataram outros obstáculos. Por intermédio de questionários e entrevistas, foram abordados três grupos de surdos, um com experiência na educação superior (alunos, egressos ou evadidos) e os outros com ensino médio completo e incompleto. As autoras assinalaram não apenas a falta de apoio dos profissionais, dos familiares e amigos, bem como a ausência de equipamentos e o pouco crédito na competência pessoal como aspectos complicadores para a frequência ao curso superior. Dentre os participantes universitários, muitos relataram dificuldades com relação à postura do professor, seja no tocante às metodologias utilizadas (frequentemente inadequadas as suas condições auditivas) ou concernente à comunicação, quando o professor apresenta voz muito baixa ou anda pela sala de aula enquanto fala, inviabilizando a leitura labial. Inclusive quando alguns estudantes surdos tentaram intervir no problema de comunicação junto aos docentes, segundo as autoras, não obtiveram sucesso (MANENTE; RODRIGUES; PALAMIN, 2007).

Além disso, importa destacar que, na ocasião do vestibular, 91\% dos universitários surdos não contaram com a presença de um intérprete de Libras, ainda que alguns deles se beneficiassem desse sistema linguístico e que esse seja um direito resguardado pelo ordenamento jurídico nacional. Para Manente, Rodrigues e Palamin (2007), que aparentemente partem de uma defesa à abordagem oralista, os resultados da pesquisa são indícios de que para a efetivação da inclusão educacional é necessária maior intervenção dos profissionais da saúde, orientando acerca de condutas adequadas e materiais facilitadores da audição que podem proporcionar a inserção social das pessoas com deficiência auditiva.

No âmbito da preocupação com o acesso dos surdos à educação superior sob o viés das políticas educacionais de inclusão, vislumbramos as dissertações de mestrado elaboradas por Nogueira (2012), com o título Políticas institucionais e ações inclusivas nas universidades: análise das condições de acesso para discentes surdos, por Patrício (2011), com o trabalho As políticas públicas de inclusão de surdos no ensino superior: especificidades do processo e por Mesquita (2013), com $O$ acesso do surdo ao ensino superior: limites e avanços das políticas educacionais de inclusão.

Nogueira (2012) direcionou seus dados com base na participação de 14 estudantes surdos de duas universidades do Ceará, visando a compreensão do desenvolvimento de políticas de inclusão e acessibilidade destes no ambiente acadêmico. Os resultados revelaram a 
necessidade de se expandir a veiculação da Libras nesse espaço, por intermédio da ampliação da oferta de ensino dessa língua e do número de intérpretes e tradutores de Libras para acompanhar os estudantes surdos, não apenas nas atividades curriculares, como também nas extracurriculares, tais como os eventos acadêmicos. Além disso, o autor asseverou que os universitários surdos anseiam pela presença de professores também surdos na universidade, profissionais com os quais eles poderão estabelecer uma comunicação direta e projetar uma relação identitária.

Sob uma perspectiva mais ampla, Patrício (2011) estudou o contexto de uma universidade particular do Paraná, contando com a participação de acadêmicos surdos, docentes e intérpretes de Libras. Com resultados bastante semelhantes aos avistados por outros autores como Nogueira (2012), Lamb (2013) e Mesquita (2013), foi observada a efetivação de políticas públicas que garantem a presença da Libras e de profissionais intérpretes e tradutores desse sistema linguístico. Patrício (2011) concorda com os autores mencionados ao afirmar a necessidade de reforçar a presença do intérprete em espaços de aprendizagem não curriculares como, por exemplo, seminários, congressos e outros eventos acadêmicos. Do mesmo modo, os resultados desse autor fortalecem a necessidade de se investir em maior capacitação de docentes e demais funcionários da universidade para atender aos alunos surdos que, vencendo as inúmeras barreiras impostas na educação básica, têm ingressado na educação superior.

Idênticas considerações são tecidas por Mesquita (2013). Para a autora, existem limites e avanços no processo de inclusão de alunos surdos na educação superior, e quando se trata de políticas educacionais direcionadas para surdos estas se concentram em seus direitos linguísticos. Neste sentido, a autora destaca a importância do Programa de Acessibilidade na Educação Superior (doravante Programa Incluir) cuja proposta é "garantir o pleno acesso e permanência das pessoas com deficiência no ensino superior, através do fomento à criação de núcleos de acessibilidade nas Instituições Federais de Ensino Superior" (BRASIL, 2016a). Mesquita (2013) restringiu sua análise ao ingresso de oito estudantes surdos, concluintes do ensino médio, na educação superior e, assim como em Lima (2012), verificou como principais barreiras, a apropriação da modalidade escrita da Língua Portuguesa e as barreiras comunicacionais geradas pela diferença linguística do sujeito surdo.

Isso posto, ainda sob um baixo quantitativo de produções relacionadas ao ingresso de estudantes surdos na educação superior, cumpre destacar que nenhum dos trabalhos aqui apresentados focalizaram os cursos de graduação destinados à formação de professores de Libras, os quais, conforme retratado pelo Decreto $\mathrm{n}^{\circ}$ 5.626/05 (BRASIL, 2005) devem priorizar 
os candidatos surdos. Logo, apesar de uma aparente semelhança, as sete obras se diferenciam do nosso objeto de pesquisa.

Por outro lado, o sujeito surdo como instrutor ou professor de Libras foi palco de discussão de 18 estudos (sendo cinco artigos, quatro teses e nove dissertações), entre os quais nove trabalhos analisaram a temática do instrutor ou do professor de Libras, porém sem se deterem aos aspectos concernentes à sua formação ou ao acesso dos surdos a essa (GESSER, 2006; MACHADO, 2009; MÜLLER, 2009; REBOUÇAS, 2009; AVELAR, 2010; PAIVA, 2010; KLIMSA, 2013; ALBRES, 2014; MOREIRA, 2014) e outros nove debateram a formação desses profissionais, mas sem o enfoque na educação superior (LEITE, 2004; SOUZA, 2006; DORNELLES; ZANELLA, 2008; VALIANTE, 2009; BUERES, 2010; FARIA, 2011; GIANINI, 2012; SCREMIN, 2012; SILVEIRA, 2008).

De fato, nossa busca revelou apenas 14 referências que articularam a presença de sujeitos surdos na educação superior e os cursos de formação de professores de Libras, sendo 11 estudos vinculados ao curso de Letras Libras e apenas três dedicados ao curso bilíngue de Pedagogia (FRANCO, 2009; MAGALDI, 2011; NEMBRI, 2011). Dentre os 11 títulos envolvidos com o curso de Letras Libras, cinco produções se concentraram na temática acerca do uso das tecnologias para garantir a acessibilidade aos surdos durante seu percurso acadêmico (GOES, 2010; SILVA, Romário, 2011; SILVA, Roseane, 2011; OLIVEIRA; WEININGER, 2013; SILVA; RODRIGUES, 2013), duas produções se dedicaram a analisar os currículos dos cursos (RAMOS, 2010; SARTURI, 2013) e outras duas focalizaram o conceito de representações dos alunos surdos sobre literatura surda (POKORSKI, 2014) e sobre surdos (COSTA, 2011). Quadros e Stumpf (2009) discutiram o curso de Letras Libras a partir do contexto da formação de professores. Todavia, assumiram um aspecto mais descritivo sobre a implementação do curso de Letras Libras pela Ufsc, com o intuito de compartilhar a organização e a experiência dessa proposta no Brasil. As autoras não tiveram como objetivo problematizar, especificamente em tal trabalho, o acesso ou a prioridade de sujeitos surdos ao referido curso e, por essa razão, consequentemente, distingue-se do foco dado aqui.

Uma maior aproximação pode ser notada na tese de doutorado $A$ experiência e a pedagogia que nós surdos queremos, produzida pelo pesquisador surdo Miranda (2007). Esse estudo colabora com o conhecimento sobre os desafios enfrentados pelos professores surdos desde a sua formação até sua atuação profissional. A partir das narrativas de professores surdos, o trabalho de Miranda (2007) foi o único encontrado que discute a formação de professores no curso bilíngue de magistério (nível médio) oferecido em Santa Maria, no Rio Grande do Sul, 
desde 2006, e sobre o curso bilíngue de Pedagogia para $\operatorname{surdos}^{24}$, criado em 2002, que fora ofertado em Florianópolis, no estado de Santa Catarina.

Na discussão dos resultados de Miranda (2007), as percepções dos professores surdos participantes da pesquisa indicam insatisfação com relação à forma como algumas instituições desrespeitam o direito de prioridade reservado aos surdos para serem instrutores ou professores de Libras. Os docentes surdos também declararam em suas entrevistas que, frequentemente, mesmo após alcançarem sob duros passos a formação em nível superior, permanecem sendo contratados como instrutores de Libras. Para tais participantes da pesquisa, a solução é transcender a pedagogia ouvintista, ou seja, preparada e pensada para e por ouvintes para uma pedagogia pensada para e por surdos.

Segundo o autor, é flagrante a necessidade de se pensar uma pedagogia voltada especificamente para a educação de surdos, pois, o país “[...] tem cursos de Pedagogia, mas não a Pedagogia dos Surdos." (MIRANDA, 2007, p. 11). Isso reflete o desejo por um curso de educação superior cujo processo seletivo, currículo, práticas pedagógicas e até o corpo docente se encontrem adequados para receberem estudantes surdos proficientes em Libras e também que se destine à formação de professores para atuar na docência junto ao público de alunos surdos. Sob essa ótica, os entrevistados surdos reivindicaram cursos universitários nos quais haja professores também surdos, em que o currículo do curso compreenda disciplinas como, por exemplo, literatura surda, política surda, história da educação de surdos, didática para surdos, cultura surda, identidades surdas e escrita de sinais.

$\mathrm{O}$ autor defende ainda que em uma pedagogia para surdos a prioridade no acesso deve ser dada aos alunos surdos, pois, conforme os relatos dos entrevistados por Miranda (2007), muitas pessoas surdas não conseguiram a aprovação no vestibular dos cursos para surdos ofertados por universidades públicas, em grande parte em virtude da falta de acessibilidade. Por essa razão, buscaram a formação docente no ensino privado onde, na percepção do autor, o currículo é pensado para a educação de alunos ouvintes. Os participantes descrevem que apenas pagavam pelo curso, mas não aprendiam "nada" (MIRANDA, 2007, p. 97), pois eram tratados com paternalismo e assistencialismo pelos docentes e pelos colegas ouvintes do curso, enfrentando inclusive, muitas vezes, a falta de intérpretes de Libras.

\footnotetext{
${ }^{24}$ Miranda (2007) não descreve mais informações sobre o curso de Pedagogia ofertado em Santa Catarina, mas dada a data da pesquisa feita pelo autor, bem como a localização descrita, é possível inferir que se trata do curso de Pedagogia a distância criado em 2002 pela Udesc. Conforme Costa et al. (2005), o referido curso foi idealizado para surdos e, por essa razão, tinha a Libras como língua de instrução. Ofertado em Florianópolis, o curso era composto de uma turma de 38 alunos surdos e sete ouvintes. Mais informações referentes a esse curso foram realizadas no capítulo introdutório.
} 
No tocante à pré-seleção das obras envolvendo o curso bilíngue de Pedagogia, os três trabalhos localizados versaram sobre a graduação ofertada pelo Ines (FRANCO, 2009; MAGALDI, 2011; NEMBRI, 2011). As dissertações de Nembri (2011) e Magaldi (2011) contrastam com o nosso interesse, pois Magaldi (2011) explorou, por meio das representações sociais de acadêmicos surdos, a correlação entre o ingresso de surdos em um curso universitário e a obtenção de melhores condições para estes se inserirem no mercado de trabalho. Por sua vez, o pesquisador surdo Nembri (2011) se guiou por observações e entrevistas com alunos surdos e ouvintes, bem como por depoimentos prestados pelos professores do curso bilíngue de Pedagogia, para evidenciar como a Libras ainda não tem sido plenamente utilizada no cotidiano acadêmico. Portanto, em ambos os estudos, o ingresso ou a prioridade dos surdos não estão sendo questionados.

$\mathrm{O}$ artigo Educação superior bilíngue para surdos: o sentido da política inclusiva como espaço da liberdade: primeiras aproximações, de Franco (2009), pode ser concebido como o texto que mais se assemelha à proposta da presente pesquisa, pois ainda que não seja seu objetivo principal, a autora cotejou o preenchimento das vagas reservadas aos candidatos surdos e aos ouvintes para o curso bilíngue de Pedagogia, durante os anos de 2006 e 2007. O objetivo consistiu em apresentar a experiência do Ines na implantação do Instituto Superior Bilíngue de Educação, discorrendo sobre os primeiros entraves do curso bilíngue de Pedagogia. Segundo a autora, a fundamentação precípua da graduação ofertada pelo Ines consistiu em assumir a Libras como língua de instrução, reservando à Língua Portuguesa em sua modalidade escrita o espaço de disciplina obrigatória. Sendo assim, para ingressar no referido curso, os alunos surdos e ouvintes são compelidos a apresentarem fluência na Libras, o que, para Franco (2009, p. 21) representou uma "[...] experiência inédita até então no Brasil."

No entanto, diversos desafios emergiram na implementação do curso, entre eles o preenchimento das vagas por candidatos surdos, pois, apesar de a instituição de ensino reservar aos estudantes surdos $50 \%$ das vagas desde o primeiro vestibular em 2006, a autora afirma que essa cota não foi totalmente preenchida nas primeiras edições do curso, o que resultou em uma maioria de alunos ouvintes e uma minoria de alunos surdos cursando tal graduação. A baixa procura pelo curso de Pedagogia inquietou a autora, pois nessa instituição, em uma parceria com a Ufsc, foi ofertado o curso de licenciatura em Letras Libras, no qual as vagas foram integralmente preenchidas por candidatos surdos. Na interpretação da autora, essa informação invalida argumentos como o de falta de divulgação do processo seletivo ou o de que não haveria surdos preparados para serem aprovados em um exame de vestibular. Aliás, a respeito desta 
última interpretação, cabe destacar que Franco (2009), ao apresentar dados do exame seletivo de 2007, identificou um desempenho superior dos concorrentes surdos, conforme a autora:

[...] segundo os resultados do vestibular de 2007, a maior média geral foi de um aluno surdo $(91,50)$. O mesmo fato também ocorreu nas duas maiores notas da prova de redação $(4,0)$. Nas provas objetivas, a maior média isolada também foi de um candidato surdo $(37,50)$. Em contrapartida, a pior média geral, bem como a pior nota na prova objetiva e de redação ficaram com os candidatos ouvintes, respectivamente $(48,50),(14,25)$ e $(10,00)$. No caso da prova de LIBRAS, 10 candidatos surdos obtiveram a nota máxima $(4,0)$ tendo o mesmo fato ocorrido com 07 estudantes ouvintes. A pior nota de LIBRAS foi de um estudante ouvinte $(15,00)$ e entre os surdos, a de 23,00 . Dois fatos podem ser considerados aqui. De um lado, o de a média total ser computada juntamente com a nota de proficiência em LIBRAS, o que daria um caráter totalmente diverso se a mesma fosse apenas classificatória. Por outro, as maiores notas isoladas são dos surdos (redação e objetiva) e as piores, muito piores, são de ouvintes. (FRANCO, 2009, p. 23-24).

Vale ressaltar que a correção das provas elaboradas pelos estudantes surdos foi realizada considerando a condição desses sujeitos enquanto usuários da Língua Portuguesa como L2. Entretanto, contraditoriamente, apesar dos ótimos resultados dos candidatos surdos no vestibular de 2007, Franco (2009) descreve que apenas quatro alunos surdos integraram as 30 vagas ofertadas no turno da tarde, e oito alunos surdos ingressaram nas 30 vagas para o turno da noite, um resultado bastante semelhante ao quantitativo do vestibular do ano de 2006, quando "das sessenta vagas oferecidas, apenas quatorze foram preenchidas por estudantes surdos [...]" (FRANCO, 2009, p. 23). Portanto, os resultados apresentados pela autora demonstram que o número pouco expressivo de candidatos surdos no preenchimento de vagas do curso bilíngue de Pedagogia do Ines não se deve ao mau desempenho dos mesmos na prova de ingresso, mas a baixa procura desse público em realizar tal curso.

Apesar das contribuições deflagradas pelas problematizações levantadas por Franco (2009), não são integrados em seu trabalho, questionamentos sobre a prioridade e o ingresso dos surdos no segmento de cursos de Letras Libras, algo que almejamos responder com nossa investigação.

Desse modo, em linhas gerais, o olhar para a literatura consubstanciou a carência de produções que discutam de forma combinada o acesso e a prioridade dos sujeitos surdos aos cursos de formação de professores de Libras ofertados no âmbito da educação superior, objetivos que integram esta pesquisa, conforme já mencionado. Além disso, outra ressalva que corrobora para o ineditismo da presente pesquisa reside no fato de nenhuma das produções encontradas ter orientado sua metodologia pela pesquisa documental pautada no uso dos editais 
de processos seletivos vestibulares dos cursos de Letras Libras e Pedagogia bilíngue. Assim, tendo em vista o acúmulo de trabalhos envolvendo entrevistas e observações, nosso desafio ao adotar outro ângulo de análise para esse contexto já pouco explorado foi, essencialmente, construir e adequar uma metodologia para o levantamento, registro e análise de editais, tal como será dimensionado no Capítulo 4.

À vista do exposto, após o levantamento e apresentação das produções que denotam proximidade ao nosso tema de pesquisa, passamos no próximo capítulo a discorrer sobre os pressupostos teóricos que guiaram nossa compreensão de surdez como uma diferença política, linguística e identitária. 


\section{IMPLICAÇÕES DO DISCURSO DA DIFERENÇA NO CONTEXTO DA SURDEZ}

Nosso posicionamento teórico parte, essencialmente, da defesa da surdez como diferença (SKLIAR, 1998, 2000, 2003, 2015, 2016) e, para além de binarismos envolvendo o patológico e o antropológico, neste capítulo traçamos considerações acerca das implicações do discurso da diferença (que não deve ser confundido com o debate da diversidade ${ }^{25}$ ) sobre o contexto sociolinguisticamente complexo do surdo e da surdez (CAVALCANTI, 1999). Nesse percurso, buscamos situar o conceito de diferença sob um olhar político afirmativo, linguístico e cultural, pois essa discussão abre caminho para se problematizar como a educação bilíngue para surdos ultrapassa a oferta da Libras em concomitância à Língua Portuguesa.

Julgamos pertinente, ainda, explicitar os conceitos com os quais compactuamos e fizemos proveito durante o capítulo da análise e discussão dos resultados, especialmente, os conceitos de diferença, identidade, língua, bilinguismo e multilinguismo. Para isso, aproveitamos o aspecto interdisciplinar da abordagem qualitativa (SCHWANDT, 2006), que guia a presente pesquisa e será discutida no próximo capítulo, para visitarmos os estudos linguísticos, sobretudo, à subárea da Linguística Aplicada dedicada aos estudos bi/multilíngues que abordam os contextos minoritários/minoritarizados (SKUTNABB-KANGAS, 1981; CAVALCANTI, 1999, 2011; MAHER, 2007), além de promover articulações com os Estudos Culturais (BHABHA, 2007) de onde emergem os Estudos Surdos (LOPES, 2011; SKLIAR, 2016). Em alguns momentos, também nos ancoramos em estudos da área do direito (DHANDA, 2008) e da leitura do conceito de identidade (HALL, 1998; MAHER, 1998).

Justificamos a escolha de nosso referencial teórico de modo transdisciplinar ${ }^{26}$, também em concordância com Brandão (2002), pois no que se refere às pesquisas em educação, originalmente, há um inevitável entrelaçamento com outras disciplinas, exigindo do investigador acompanhar o movimento e o debate de diferentes áreas de conhecimento. $\mathrm{Na}$ atualidade, a autora ainda declara que essa premissa não se restringe às produções na educação, pois, com efeito, tem se tornado cada vez mais difícil definir fronteiras entre os campos do conhecimento, ou seja, emprestando suas palavras "não se progride hoje, em quase nenhum campo científico sem a interlocução com as áreas circunvizinhas.” (BRANDÃO, 2002, p. 63).

\footnotetext{
${ }^{25}$ Essa questão será debatida adiante no item 3.1.1.

${ }^{26}$ Utilizamos o termo "transdisciplinar" seguindo a linha de raciocínio de Cavalcanti (2011) para quem os prefixos "multi" ou "pluri" cavam de certa forma uma separação, ao passo que "trans" promove uma compreensão dialógica de maior entrelaçamento. Cumpre salientar que a autora tece essas considerações sobre esses prefixos sob o conceito das práticas linguísticas e somos nós quem importamos para a visão disciplinar.
} 
Por essa razão, fundamentados nessa lógica, tomamos a liberdade de recorrer aos diferentes campos do saber para construção de nosso aporte teórico. Ademais, talvez seja oportuno mencionar que essa construção teórica não poderia ser diferente, tendo em vista a formação desta pesquisadora, graduada em um curso de Pedagogia sob a já extinta habilitação em educação especial na área da "deficiência auditiva" pela Universidade Estadual Paulista, especializada em surdez pela Faculdade de Ciências Médicas e feita Mestre em Linguística Aplicada pelo Instituto de Estudos da Linguagem da Universidade Estadual de Campinas (Unicamp) e, atualmente, de volta ao ninho da Educação, defendendo o doutorado em Educação pela Faculdade de Educação da Universidade de São Paulo. Essa trajetória acadêmica desvela não apenas o caráter multidisciplinar projetado por diferentes áreas e instituições (leia-se comunidades científicas), mas o "lócus de enunciação"27 (MENEZES DE SOUZA, 2004, p. 119) do qual partimos.

\subsection{A LEITURA DO SURDO E DA SURDEZ SOB O PRISMA DA DIFERENÇA}

Durante muito tempo imperou no cerne da educação de surdos o discurso da deficiência, autorizado e legitimado pelas práticas oralistas que preconizavam (e ainda preconizam) a normalização e a reabilitação das pessoas surdas sob o enfoque no aproveitamento do resíduo auditivo, no benefício das tecnologias no campo da audiologia, na leitura orofacial, no treinamento da fala, entre outros.

De acordo com Skliar (1998, 2016) e Silva (2005), em âmbito nacional, esse cenário começou a se transformar na década de 1990, quando a representação do surdo e da surdez como deficiente e deficiência passou a ser produzida por alguns estudiosos e profissionais sob uma nova concepção ideológica calcada, respectivamente, no diferente e na diferença. Segundo Skliar (2016), foi um momento que propiciou o fortalecimento de concepções sociais e antropológicas da surdez, influenciando sobretudo a organização escolar e as práticas pedagógicas dedicadas à educação de surdos.

Silva (2005, p. 45) relata que essa mudança de paradigmas permitiu desconstruir "velhas certezas" que ecoavam na fala dos próprios familiares de surdos e especialistas da área, crédulos de que para o aprendizado da leitura e da escrita seria, precipuamente, necessário aprender a

\footnotetext{
27 De acordo com a leitura sociodiscursiva de Menezes de Souza (2004, p. 119) a respeito dos estudos desenvolvidos por autores como Bakhtin e Bhabha, o narrador, escritor ou quem estiver falando sempre está situado "[...] socialmente em determinados contextos ideológicos, históricos e sociais, marcados por todas as variáveis existentes nesses contextos (classe social, sexo, faixa etária, origem geográfica etc.)" e a esse contexto, atravessado por ideologias e valores socioculturais atribui-se o conceito de "lócus de enunciação".
} 
fala oral. Sob essa lógica opressora, gastava-se uma grande parte do tempo da vida escolar dos surdos na promoção de uma pedagogia corretiva que perseguia o ensino da oralidade. Por sua vez, o insucesso escolar dos aprendizes surdos era atribuído somente a eles, isentando a escola e todo o sistema educacional que não eram projetados para atender esse contingente de alunos e, inclusive, o professor que desconhecia a Libras e utilizava os mesmos e inadequados materiais e metodologias empregados na educação dos alunos ouvintes.

A ótica do surdo enquanto sujeito bilíngue e bicultural, ou seja, tendo reconhecida a Libras como sua primeira língua (L1) e a Língua Portuguesa como a L2 ${ }^{28}$, permitiu o surgimento de uma nova concepção do surdo sob o viés socioantropológico, termo que passou a ser difundido e utilizado por vários autores da área (SANTANA; BERGAMO, 2005; SILVA, 2005; BEHARES, 2015; SKLIAR, 2000, 2015; CHOI et al., 2011; LUNARDI, 2016; THOMA, 2016) para se contrapor a uma concepção clínico patológica.

Nessa linha de raciocínio, a proposta bilíngue marca o reconhecimento da surdez como diferença, mas a conversão não é automática. Cabe problematizar que, em concordância com Skliar (2016), essa mudança de paradigmas, mesmo sob o amparo da legislação (BRASIL, 2002, 2005) foi insuficiente para se abandonar por completo as práticas, crenças, estereótipos e representações advindos de anos de hegemonia do discurso oralista, enraizados no imaginário não apenas dos profissionais, como também dos familiares e, muitas vezes, dos próprios surdos que advogam pela necessidade de se comunicar pela oralidade para ser aceito e integrado à sociedade.

Isso ocorre, pois embora a representação seja uma formação (ou deformação) da linguagem, como preconiza Bhabha (2007), na construção ideológica da alteridade, a repetibilidade do discurso na história é capaz de materializar ou fixar o sujeito sob estereótipos que se reproduzem como se fossem cópias fiéis da realidade, sem a necessidade de provas, pois lançam por si só o efeito de verdade probabilística. Nessa concepção, “[...] o estereótipo, que é sua principal estratégia discursiva, é uma forma de conhecimento e identificação que vacila entre o que está sempre 'no lugar', já conhecido, e algo que deve ser ansiosamente repetido [...]" (BHABHA, 2007, p. 105).

Assim, para não incorrermos no risco de ingenuidade, apropriamo-nos da teoria de Bhabha (2007) para compreender o poder dos estereótipos na construção de práticas marginalizadoras e discriminatórias, entendendo que, após anos de prevalência do discurso

\footnotetext{
${ }^{28}$ Skliar (2000) enfatiza que o fato da criança surda aprender a Libras não inviabiliza a aquisição do português como uma L2, pois propiciando e respeitando a língua de sinais como sua L1, ela será capaz de desenvolver domínio em ambas.
} 
médico, foram construídas e calcificadas representações do sujeito surdo como deficiente que não são nem serão facilmente desmontadas.

Em suma, sabemos que o reconhecimento da Libras está longe de produzir por si só o apagamento da concepção clínico-patológica e sua substituição imediata por uma visão socioantropológica $^{29}$. É válido refletir que muitos especialistas da educação de surdos, que atuam nos dias de hoje, formaram-se dentro de um modelo médico, ao qual Behares (2015) denomina de "deficientismo". Esses profissionais não deixam de existir nem abandonam seus conhecimentos acadêmicos a partir do momento que um novo modelo lhes é apresentado ou imposto. Importa considerar o conflito no qual se encontram inseridos, assimilando de forma não harmônica novas orientações que colidem com as crenças e teorias (leia também representações e estereótipos) com as quais, por anos, guiaram a prática pedagógica deles em sala de aula.

Nessa direção, convém notar que o Oralismo e suas percepções sobre o surdo e a língua de sinais não se fixam no passado, bem como o seu oposto, o Bilinguismo e seu discurso pautado no "diferencialismo" (BEHARES, 2015) não dominam todo o tempo presente. O atual cenário da educação de surdos é, portanto, atravessado pelas duas abordagens, uma que se acredita(va) dever estar no passado (o Oralismo) e outra que se espera(va) governar o presente (o Bilinguismo), mas como recorda Skliar (2003, p. 42) “[...] o presente não é um, senão dois: cada presente é, ao mesmo tempo, um presente e um passado.”

Para esse autor, o tempo presente é sempre repleto de paradoxos, visto que remonta ao passado, embora não se desvincule do presente e se encha de expectativas de um futuro que ainda não chegou, mas que logo será também, de algum modo, a memória do presente. Em um desses paradoxos, o autor sugere que "[...] o passado não continua num presente que já foi, senão que convive com ele.” (SKLIAR, 2003, p. 43).

Além disso, o autor chama a atenção para o fato de ser possível o tempo se desdobrar e ser, simultaneamente, único e múltiplo. Quando se pauta pela "mesmidade"30 e rejeita as diferenças, Skliar (2003) entende que se instala um único tempo, no qual só o mesmo é admitido. Por sua vez, a ruptura com essa "mesmidade" e o reconhecimento do outro e da diferença proporciona à temporalidade o caráter de multiplicidade.

\footnotetext{
${ }^{29}$ Cumpre salientar que mesmo as noções de patológico e socioantropológico se constituem a partir de práticas e espaços de hibridismo.

${ }^{30} \mathrm{O}$ autor usa "mesmidade" como o antônimo do conceito de alteridade que remete ao outro, ou aos outros, que não sou eu e que, assim, não corresponde a minha "mesmidade" (SKLIAR, 2003).
} 
Neste aspecto, chama-nos a atenção o fato de a educação de surdos no tempo presente apresentar múltiplas constituições que não, necessariamente, estarão em sua totalidade alinhadas ao viés social da surdez como diferença linguística e isso pode ocorrer, conforme Lopes (2011, p. 55), “[...] mesmo naquelas escolas que se dizem acolhedoras da diferença cultural do surdo e que pretendem desenvolver um currículo surdo.”

À vista disso, Lopes (2011) admite que nem todas as interpretações da surdez são sustentadas pela base antropológica e isso inclui as escolas bilíngues para surdos, onde o discurso clínico da deficiência e da normalização pode estar em vigor. Segundo essa autora, a surdez como um resultado biológico da perda auditiva, da lesão dos tímpanos ou dos fatores hereditários e adquiridos são invenções da ciência que têm sido difundidas no campo da educação de surdos. A autora não nega a falta de audição, mas postula que:

[...] se a palavra surdez remete a um sentido clínico terapêutico, é porque a produzimos dessa forma - acontecimento que nos permite virar de costas para essa interpretação e passar a operar com outras formas de significação. $\mathrm{O}$ sentido clínico também é uma invenção cultural, assim como o sentido antropológico, entre tantos outros. Diante de tal compreensão, o que se torna imprescindível é demarcar o terreno e escolher bem os parceiros que vão ajudar a definir um tipo de entendimento e um tipo de construção de sentidos para a questão do ser surdo. (LOPES, 2011, p. 17, grifo do autor).

Compactuamos a linha de pensamento dessa pesquisadora, e entendemos que se a surdez e suas representações patológicas foram inventadas por intermédio das estratégias discursivas, do mesmo modo, nós podemos (re)construir novos discursos que inscrevam os surdos no sentido cultural e antropológico da diferença. Para isso, segundo Lopes (2011), um primeiro passo é deslocar a noção de surdez atrelada à falta da "fala" ou do "som", para focalizar naquilo que esta marca como diferente e que propicia o agrupamento conhecido como comunidades surdas. Mas, qual seria esse marcador?

Inicialmente, acreditou-se que a composição das comunidades surdas resultava da falta de audição. Segundo Behares (2015), esse argumento foi descartado na década de 1960 por dois motivos, primeiro não só pelo fato de os surdos serem um grupo heterogêneo, apresentarem diferentes graus de perda auditiva, bem como experiências diversas com relação à surdez. Um segundo motivo consiste na constatação de que os integrantes das comunidades surdas não são apenas os surdos, como também as pessoas ouvintes, sejam eles familiares, profissionais ou outros. Então, na década de 1970, Behares (2015) descreve que se fortaleceu a defesa de a língua de sinais ser o elemento identificatório responsável pelo agrupamento das comunidades surdas. 
No entanto, atualmente, admite-se que a língua não é o único aspecto identificatório, pois, em concordância com Lopes (2011), há outros elementos que perpassam essa marcação identitária:

[...] aqui estão implicadas formas de se relacionar, formas de se identificar com alguns e se distanciar de outros, formas de se comunicar e de utilizar a visão como um elo aproximador entre sujeitos semelhantes. A surdez, nessa narrativa, é marcada pela presença de um conjunto de elementos que inscrevem alguns sujeitos em um grupo, enquanto que outros são deixados de fora desse grupo. Assim, as formas de comunicação advindas da condição surdez são um dos elos mais fortes da própria comunidade, uma vez que nosso modo de ver, entender e nos comunicarmos entre pares se dá efetivamente segundo processos no comum, para os quais as marcas identitárias são uma condição radicalmente necessária. (LOPES, 2011, p. 22-23, grifo do autor).

Seguindo essa análise, são as formas de se comunicar e de vivenciar o mundo através das experiências visuais que constituem marcadores identitários das comunidades surdas (LOPES, 2011), não apenas a língua de sinais e, de forma alguma, o caráter biológico ${ }^{31}$. Portanto, a leitura do surdo pelas lentes do conceito de diferença pressupõe o distanciamento das teorias biológicas veiculadas sobre o surdo e a surdez e, em consonância com Santana e Bergamo (2005), essa postura está associada também a uma mudança terminológica e conceitual, abandonando-se expressões como "deficiente auditivo", cuja semântica se apoia na ausência, para acolher a nomenclatura "surdo" ou "Surdo" (SANTANA; BERGAMO, 2005; CHOI et al., 2011).

A premissa principal para se rejeitar a noção patológica foi concebida, pois a anormalidade ou a deficiência está pautada pela ausência de uma língua e a partir do momento em que se reconhece a Libras como sistema linguístico das pessoas surdas compreende-se que se o surdo pode "falar" por meio da língua de sinais, não existe deficiência, sua condição se equipara às das comunidades linguísticas minoritárias/minoritarizadas (conforme será abordado posteriormente).

O termo deficiente ou deficiências, como defendido por Skliar (2003), são resultados de representações dominantes de um modelo biológico que insiste em interpretar o mundo sob a régua da norma e da normalidade e, para isso, cria para o “outro”, que é diferente de “nós”, uma

\footnotetext{
${ }^{31}$ Pimenta e Quadros (2008) e Choi et al. (2011, ao retratarem a cultura surda, descrevem que há dentro desse contexto inúmeras questões que extrapolam o uso da Libras, tal como costumes e comportamentos (como, por exemplo, a forma de se apresentar, de chamar a atenção de um surdo, de se estabelecer contato visual durante a interação, o batismo do sinal pessoal etc.), expressões artísticas (tal como a literatura, as poesias e o humor surdo), os pontos de encontro, o uso das tecnologias (como a campainha visual, a legenda oculta na televisão, o despertador vibratório etc.).
} 
"alteridade deficiente". No entanto, conforme o autor denuncia, a alteridade surda não é facilmente administrada sob uma perfeita polarização entre a normalidade e a anormalidade ou mesmo entre o clínico-patológico e o socioantropológico, pois há nesses contextos territórios intermediários que não se fecham no binarismo dos modelos social e médico, mas que transitam e flutuam entre eles. Com isso, é possível se deparar com diversas representações sobre a surdez, dentre elas a surdez como diferença política, como experiência visual, como identidade múltipla ou multifacetada e/ou ainda dentro do discurso sobre a deficiência (SKLIAR, 2015).

Uma das formas de se atender parcialmente as reivindicações da surdez como diferença tem sido fomentada no bojo do discurso da diversidade que, ao invés de tensionar as relações de poder existentes na diferença, preconiza a igualdade na diversidade, ou seja, parte do pressuposto de que por sermos todos diferentes, de algum modo podemos ser considerados iguais. A esse respeito, julgamos oportuno lançar luzes sobre os riscos que a bandeira da diversidade pode propalar.

\subsubsection{A diferença fora do discurso da diversidade}

O conceito de diversidade tal como se divulga tem sido criticado por vários autores que não necessariamente tocam na questão da surdez (SILVA, 2000; SKLIAR, 2003; BHABHA, 2007; TAGATA, 2007), mas com os quais nos alinhamos para construir esse diálogo teórico. Ao tratar do conceito de cultura, Bhabha (2007, p. 63, grifo do autor) propõe uma distinção para a diversidade e a diferença, entendendo a diferença como "[...] um processo enunciação da cultura como 'conhecível', legítimo, adequado à construção de sistemas de identificação cultural.” Enquanto a diversidade consiste no "[...] reconhecimento de conteúdos e costumes culturais pré-dados [...]" (BHABHA, 2007, p. 63) que contribui para uma noção liberal de multiculturalismo. Para o autor uma visão mais crítica é atribuída ao conceito de diferença envolvendo os processos políticos, os mecanismos de poder e de autorização e discriminação implícitas. A diversidade, por outro lado, apoia-se na busca de uma identidade coletiva unida desvelando um desejo totalitário de homogeneizar as diferenças (SKLIAR, 2003; BHABHA, 2007; TAGATA, 2007). Para Tagata (2007, p. 138) “pensar em termos de diferença cultural de Bhabha possibilita desmascarar discursos pretensamente liberais e pluralistas [...]". Mas, afinal quais seriam as consequências de incorrermos em um multiculturalismo liberal?

Em concordância com Skliar (2003, 2016), o risco seria de cairmos na armadilha de assumir uma ideologia de assimilação ou de igualitarismo naturalizado, uma noção que se opõe ao diferencialismo (BEHARES, 2015) com a qual nos alinhamos na presente pesquisa. Sob esse 
raciocínio, não se deixa de reconhecer a existência da diferença, mas é como se cada diferença fosse igual em seu fragmento, ou seja, como se houvesse uma essência identitária e apenas uma única forma de ser mulher, ser surdo, ser negro ou homossexual. Essa perspectiva avança homogeneizando as comunidades, partindo da lógica de que todos os surdos vivenciam sua surdez do mesmo modo, assim como as mulheres as questões de gênero, os negros sua negritude e assim por diante (SKLIAR, 2003).

Em oposição a essa vertente, concordamos que a diferença pertence ao campo do múltiplo e não ao diverso, pois, segundo Silva (2000, p. 100-101):

A diversidade é estática, é um estado, é estéril. A multiplicidade é ativa, é um fluxo, é produtiva. A multiplicidade é uma máquina de produzir diferenças diferenças que são irredutíveis à identidade. A diversidade limita-se ao existente. A multiplicidade estende e multiplica, prolifera, dissemina A diversidade é um dado - da natureza ou da cultura. A multiplicidade é um movimento. A diversidade reafirma o idêntico. A multiplicidade estimula a diferença que se recusa a se fundir com o idêntico.

Portanto, a diversidade tende a essencializar e naturalizar a diferença, mas, além disso, Silva (2000) destaca que o discurso da diversidade no escopo do multiculturalismo faz um apelo à postura benevolente de tolerância e respeito ao diverso. Nessa direção, são deflagradas novas dicotomias envolvendo o "[...] dominante tolerante e o dominado tolerado [...]" ou da "[...] identidade hegemônica mas benevolente e da identidade subalterna mas 'respeitada'." (SILVA, 2000, p. 98).

Essa tolerância subjacente no discurso da diversidade reforça uma hierarquia na alteridade, pois a tolerância é aplicada por "nós" ao "outro". Segundo Skliar (2003), a diversidade está centrada nos outros, nunca na "mesmidade", portanto somos "nós" quem "hospedamos" o outro na "mesmidade". Desse modo, Skliar (2003, p. 203) descreve que a pedagogia da diversidade converge, ao mesmo tempo, para a hospitalidade e a hostilidade com o outro, pois “[...] anuncia sua generosidade e esconde sua violência de ordem.”

Logo, importa esclarecer que, tal como nos alerta esse autor, diversidade e diferença se passam por termos similares, mas seus usos e o caráter das representações sobre a alteridade produzidas não são concebidos igualmente. Para o autor, a suposta semelhança discursiva entre diferença e diversidade é, portanto, superficial e artificial. Skliar (2003, 2016) também se embasa na teoria de Bhabha (2007), e sintetiza a leitura que faz desse autor ao entender que a:

[...] noção de diversidade é utilizada geralmente em um discurso liberal que se refere à importância de sociedades plurais e democráticas e que junto com 
ela surge sempre uma norma transparente, construída e administrada pela sociedade que hospeda, que cria um falso consenso, uma falsa convivência, uma estrutura normativa que detém e contém a diferença cultural. (SKLIAR, 2003, p. 137).

Diante do exposto, fundamentamos nosso entendimento sobre o conceito de diferença fora do debate da diversidade, por conceber que a diversidade mascara as diferenças sob o manto do igualitarismo, além de cavar uma divisão entre aquele que tolera e o tolerado. Cumpre enfatizar que, ao assumirmos nossa intenção de evidenciar e marcar a diferença, não nos contrapomos a noção de igualdade, pois em consonância com Skliar (2003) o oposto de igualdade é a desigualdade e não a diferença. A diferença deve ser confrontada a luz da mesmidade.

No entanto, para Skliar (2003, 2016) e Lopes (2011), as discussões envolvendo a temática da diferença, sob o conceito que aqui defendemos, não têm sido totalmente contempladas na Educação Especial, uma vez que essa área ainda apresenta laços muito estreitos com os saberes médicos e psiquiátricos e, por essa razão, inaugurou-se um novo território para abrigar a temática da educação de surdos, denominado de Estudos Surdos.

\subsubsection{Os estudos surdos}

Na visão de Skliar (2016), a diferenciação do conceito de diversidade e diferença conduz ao distanciamento da representação que circula na Educação Especial de que os surdos, os cegos, os deficientes intelectuais e os deficientes físicos têm algo em comum, especialmente, pois que essa semelhança está pautada na questão patológica que, como sabido, encontra-se geralmente vinculada a um laudo clínico que gerencia o acesso aos seus serviços.

Abrimos aqui um parêntese, antes de abordarmos oficialmente os Estudos Surdos por julgarmos pertinente salientar que, recentemente, já se reconhece a existência de uma discussão dentro da Educação Especial visando substituir a conceituação orgânica para um modelo social de deficiência, que, conforme Diniz (2013), deslocam os estudos sobre esse contexto, tradicionalmente situado no campo biomédico e pautado nos impedimentos corporais para novas perspectivas teóricas e políticas ${ }^{32}$.

\footnotetext{
32 Nosso intuito aqui também é justificar que, uma vez, inseridos na Educação Especial nós mesmos não compactuamos com esse modelo biológico e, portanto, não se pode generalizar que todos os discursos advindos desse campo são, necessariamente, pautados no discurso clínico da deficiência. Do mesmo modo, cumpre destacar que, mesmo dentro da área clínica ou médica também existem profissionais que adotam uma visão social do surdo ou do conceito de deficiência.
} 
A esse respeito, a própria Convenção Internacional sobre os Direitos das Pessoas com Deficiência (BRASIL, 2010a) segue nessa direção, ao não inscrever a deficiência em uma característica biológica, mas nas barreiras atitudinais e ambientais que obstaculizam a interação e a participação dessas pessoas na sociedade em igualdade de oportunidades. Ao ser entrevistado por Diniz (2013, p. 242), Colin Barnes, considerado um dos fundadores do modelo social de deficiência, relata que quando a deficiência é situada no sujeito, diz-se que este é deficiente por ter um impedimento, mas na visão social a qual esse autor está ancorado, apostase na lógica inversa, pois se advoga que "essas pessoas são deficientes por causa da sociedade."

Isso posto, para Barnes, é a sociedade que cria as desvantagens e depois as atribui ao indivíduo, e isso se reforça nas práticas discursivas, por exemplo, quando se usa termos como "pessoas com deficiência", uma vez que essa expressão circunscreve a deficiência como um aspecto individual, ou seja, que pertence à pessoa e não à sociedade. Além disso, para a disseminação desse modelo social de deficiência, Barnes defende a necessidade de abandonar a imagem negativa conotada à deficiência para, em seu lugar, assumir uma identidade política de afirmação, tal como têm ocorrido com os grupos sociais de pessoas homossexuais e os grupos de pessoas negras (DINIZ, 2013).

Nossa intenção com essa amostra é evidenciar que já há estudos fomentados no escopo da Educação Especial também alinhados a um modelo social, assim como vislumbrado na perspectiva socioantropológica da surdez, e entendemos que nossa tese está inserida nesse espaço possível do diálogo crítico entre Educação Especial e Estudos Surdos, tal como outros trabalhos da Universidade de São Paulo que nos precede (BRITO, 2013; SOARES, $2013^{33}$ ).

Do mesmo modo, não podemos deixar de lembrar a contribuição da formação docente em Educação Especial realizada pela Universidade Federal de Santa Maria (UFSM) e pela Universidade de São Carlos como instituições dedicadas ao discurso da surdez a partir do registro da diferença, da cultura, das identidades e da língua de sinais. Ainda que inserida na área da Educação Especial, a UFSM realiza há muitos anos um trabalho de referência na formação de professores e pesquisadores em nível de graduação e pós-graduação envolvidos com a valorização do surdo, da surdez e da língua de sinais sob o viés antropológico, sendo muitas das suas produções arroladas durante a redação desta tese (MÜLLER, 2009; LAMB, 2013; SARTURI, 2013; GOULARTE, 2014; LUNARDI, 2016). No entanto, apesar da

\footnotetext{
${ }^{33}$ Assim como a presente pesquisa construída sob a orientação da $\operatorname{Prof}^{\text {a }} \operatorname{Dr}^{\mathrm{a}}$ Rosângela Gavioli Prieto, destacamos no campo da surdez os estudos de Brito (2013) e Soares (2013) que foram produzidos dentro da área da Educação Especial, porém já filiados a uma análise crítica e social desse contexto que, sem dúvida, somam contribuições ao campo dos Estudos Surdos.
} 
existência desses exemplos, admitimos ser inegável a grande influência exercida pela área clínica no campo da Educação Especial, sobretudo no passado (JANNUZZI, 1992; SKLIAR, 2003; PRIETO, 2000), mas cuja memória ainda "respinga" no presente, impregnando parte considerável de nosso fazer e pensar pedagógico, como será evidenciado durante a análise de nossos resultados.

Fechando o parêntese. É, portanto, com base no desafio de melhorar esses paradigmas dominantes na Educação Especial que Skliar (2016) propõe alocar as práticas e estudos envolvendo a educação de surdos em um novo campo conceitual, a saber: os Estudos Surdos.

Além do próprio Skliar (1998, 2000, 2015, 2016), inúmeros autores brasileiros e estrangeiros contribuíram para proliferar essa nova tendência, tal como a coletânea intitulada Estudos Surdos organizada por Quadros (2006b, 2008), Quadros e Perlin (2007) e Quadros e Stumpf (2008) que reúne pesquisadores surdos e ouvintes preocupados com diversas questões pertinentes ao contexto da surdez, seja concernente às línguas de sinais, às identidades, às práticas pedagógicas, à cultura surda, à história, entre outros.

Na mesma direção, Lopes (2011) discorre que seus estudos, bem como as produções de pesquisadores do Núcleo de Pesquisa em Políticas de Educação para Surdos (Nuppes ${ }^{34}$ ), do qual participa, estão inseridas nos Estudos Surdos, designação que, surgiu no Brasil com a intenção de traduzir os chamados deaf studies, difundidos em vários países, sobretudo nos Estados Unidos. Nas palavras da autora, os Estudos Surdos integram “[...] uma ampla gama de temas, problemas e enfoques teóricos que muito tem contribuído para uma compreensão mais refinada e matizada dos surdos e da surdez.” (LOPES, 2011, p. 13).

Nessa vertente, os Estudos Surdos se alinham à concepção de surdez como diferença e apresentam estreita relação com os Estudos Culturais (LUNARDI, 2016), além de se constituírem como um campo conceitual para debates políticos e educacionais articulados com os estudos linguísticos, culturais, comunitários e identitários abrangendo a temática da surdez. Skliar (2016) assevera que os questionamentos desse ramo de estudos não estão centrados especificamente na surdez, nos surdos, nas identidades surdas ou na língua de sinais, mas nas representações dominantes, hegemônicas e ouvintistas produzidas sobre todos esses aspectos.

Convém esclarecer que o termo ouvintista, assim como as derivações ouvintismo e ouvintização foram utilizadas pelo autor (SKLIAR, 2015, 2016) para referir o conjunto de representações, práticas de significação ou dispositivos pedagógicos que abordam o surdo sob

\footnotetext{
${ }^{34}$ Na obra citada (LOPES, 2011) o grupo é referenciado como Nuppes, embora, atualmente, seja intitulado como Grupo Interinstitucional de Pesquisa em Educação de Surdos ou Gipes.
} 
percepções biológicas atreladas à noção de deficiência. A partir do ouvintismo, os surdos são narrados pela ótica da normalidade ouvinte, sendo considerados como sujeitos incompletos ou inferiores, indivíduos sem audição que necessitam de intervenções terapêuticas para se ajustarem ao padrão da sociedade ouvinte.

No entanto, na literatura, também é possível encontrar a referência ao termo "audismo" no lugar de "ouvintismo". Lopes (2011) assinala que "ouvintismo" foi um conceito criado para explicar as representações dos ouvintes sobre os indivíduos surdos, tendo como parâmetro a história de opressão que o grupo de pessoas surdas sofreu sob o domínio das pessoas ouvintes, conforme apresentado no capítulo introdutório. Contudo, nessa concepção o "ouvintismo" focaliza a pessoa ouvinte, desconsiderando o contexto no qual as práticas pedagógicas corretivas, criticadas pelos surdos, estavam assentadas. Para a matriz disciplinar moderna, a autora defende que essa nomenclatura não esclarece totalmente as questões, pois uma vez pautada nos grupos sociais (surdos e ouvintes), deixa de atender e problematizar a norma da audição que, atualmente, assume centralidade. Portanto, para Lopes (2011, p. 37) seria mais adequado acolher a palavra "audismo" ao versar sobre a "[...] forma de vida organizada a partir da norma da audição. Tal forma de vida ultrapassa aquele que ouve e aquele que não ouve."

$\mathrm{Na}$ esteira dos Estudos Surdos, diversos trabalhos têm sido publicados com o intuito de aprofundar e difundir o debate, não apenas sobre o ouvintismo ou o audismo, bem como a representação das identidades surdas pelo viés da diferença, que implica também o reconhecimento de sua pluralidade, tópico de discussão que abordaremos na sequência.

\subsection{REFLETINDO ACERCA DAS IDENTIDADES SURDAS E DAS MÚLTIPLAS CONDIÇÕES DE DESVANTAGEM}

Diferença é o conceito e o elemento que atravessa este capítulo e, portanto, não poderíamos nos furtar de abordar sua estreita relação com a construção e o estabelecimento das identidades, principalmente, com a atenção que essa discussão recebe nos Estudos Culturais e nos Estudos Surdos. Eventualmente, a concepção de identidades surdas com a qual nos filiamos será marcada durante a discussão dos nossos resultados, isto remete ao compromisso de elucidarmos o entendimento que temos a esse respeito.

Para Hall (2000) e Woodward (2000), as identidades são constituídas por meio da diferença, ou seja, para existirem dependem da marcação da diferença entre "quem é" e "quem não é” e isso pode ser contemplado pelo sistema de representações ou pelas formas de exclusão social. No plano das representações, Silva (2000) relata que há uma associação com atribuição 
de sentidos positivos e negativos. Sob o aspecto da positividade, o discurso se estabelece naquilo que se autoafirma ser, como, por exemplo, "sou brasileiro", "sou negro", "sou heterossexual", "sou jovem", "sou homem”. No entanto, essa autoafirmação está intimamente associada a uma cadeia de negações, pois conforme esse autor, quando se declara "sou brasileiro", subliminarmente estão contidas as negativas "não sou argentino", "não sou chinês", "não sou japonês" e, assim, poder-se-ia prosseguir de modo quase interminável. Nesta tônica, ao deixar as declarações negativas implícitas, Silva (2000) explica que a gramática simplifica essa cadeia de negações, ao mesmo tempo em que, oportunamente, omite-a.

Do mesmo modo, ao estabelecer a relação entre aquilo que somos e não somos, determinamos não apenas uma identidade própria, por exemplo, "eu sou brasileira", mas uma oposição ao outro quando dizemos "ela é argentina", afirmações que estão basicamente orientadas pela diferença entre a "mesmidade" e a alteridade. Isso cria uma interdependência contínua entre identidade e diferença, uma vez que se tornam conceitos praticamente indissociáveis (SILVA, 2000).

Para Woodward (2000), a classificação simbólica de categorias construídas por meio de oposições de uma identidade em relação à outra cede espaço para o estabelecimento de divisões entre "locais" (insiders) e "forasteiros" (outsiders), como uma busca incessante pela ordem social. Conduzidas dessa forma, as diferenciações agem, frequentemente, como instrumentos de marginalização e exclusão daqueles vistos como outsiders. Mas, seria possível falar de identidade e diferença sem recair em oposições? Woodward (2000, p. 52) inspirada em Simone de Beauvoir questiona: "Podem as mulheres ser diferentes dos homens sem serem opostas a eles?”. E aqui talvez seja pertinente complementar a discussão indagando: Poderiam os surdos serem considerados "diferentes" sem serem vistos como o oposto da identidade ouvinte?

Esses questionamentos chamam a atenção para o modo como as diferenças têm sido utilizadas para classificar os sujeitos em identidades e simultaneamente reproduzir relações de poder que induzem a métodos de exclusão. Contudo, em concordância com Silva (2000, p. 76), não podemos perder de vista que:

Além de serem interdependentes, identidades e diferença partilham uma importante característica: elas são resultados de atos de criação linguística. Dizer que são resultados de criação significa dizer que não são "elementos" da natureza, que não são essências, que não são coisas que estejam simplesmente aí, à espera de serem reveladas ou descobertas, respeitadas ou toleradas. A identidade e a diferença têm que ser ativamente produzidas. Elas não são criaturas do mundo natural ou de um mundo transcendental, mas do mundo cultural e social. Somos nós que as fabricamos, no contexto de relações culturais e sociais. A identidade e a diferença são criações sociais e culturais. 
Diferença e identidade são, portanto, fabricações da linguagem e não devem ser correlacionadas a nenhuma essência do que é ser homem, mulher, brasileiro, argentino, negro, branco, índio, surdo ou ouvinte, pois todas essas identidades são construídas no universo linguístico discursivo das representações. Apesar disso, Woodward (2000) retrata sua preocupação, pois afirma que constantemente o corpo tem sido utilizado para estabelecer "verdades biológicas" a respeito de quem nós somos, servindo de fundamento para a determinação de identidades. Contrapondo-se a essa noção orgânica de identidade, Maher (1998) ao se referir às identidades indígenas enfatiza que não se guia por essência alguma, seja no que tange a busca por indivíduos cromossomaticamente semelhantes ou que apresentem determinadas crenças, costumes, língua ou ornamentos, pois, segundo essa autora, o critério racial foi abandonado pela Antropologia pela sua inoperância e o cultural em virtude de sua mutabilidade.

Com base nessas autoras, partimos do princípio de identidades surdas, sem pressupor que haja um único marcador identitário (LOPES, 2011) para se definir quem é ou não surdo, evitando o engessamento desse conceito em uma característica audiológica (ouvir ou não ouvir), linguística (saber ou não língua de sinais) ou cultural (conhecer ou não a cultura surda), entendendo que pode haver diferentes maneiras de se vivenciar as identidades surdas. Essa apropriação do conceito de identidades surdas, em nossa visão, parece ser basilar para a mudança de paradigmas que se apregoa com a defesa de uma educação bilíngue e bicultural, bem como com a necessidade de profissionais formados sob uma concepção antropológica do surdo e da surdez.

Neste sentido, compactuamos com Skliar (2015), para quem o fato de ser surdo não deve estar aprisionado a uma identidade única e essencializada, comprovada pela existência de traços comuns e universais, pois as identidades não são fixas nem podem ser fixadas, posto que adquirem sentido no tempo, nos grupos culturais, nos espaços geográficos e na própria interação com o outro. É nessa perspectiva que Bhabha (2007, p. 85) sugere as identidades como um "processo problemático" e nunca como um "produto acabado".

A compreensão de identidades plurais, partilhada com os autores supramencionados está, de acordo com Hall (1998, 2000), associada ao contexto da modernidade tardia em que estamos situados e que propõe a fragmentação das identidades do sujeito pós-moderno. Esse autor apresenta três concepções de identidade, posicionadas conforme o sujeito do iluminismo, o sujeito sociológico e o sujeito pós-moderno. O sujeito do iluminismo consiste em um indivíduo centrado, unificado, dotado de razão e de uma centralidade conformada em sua 
própria individualidade, a identidade é, portanto, individualista e sempre descrita no masculino. O sujeito sociológico não está centrado no individual, pelo contrário, percebe que a formação de sua identidade ocorre na interação entre o eu e a sociedade, propondo um diálogo entre o sujeito e o mundo cultural exterior e, ao mesmo tempo, situando o local que cada indivíduo ocupa nesse mundo. Por sua vez, define que o sujeito pós-moderno emerge de uma sociedade globalizada em que são produzidas novas relações de espaço e tempo. Dessa realidade, deriva o sujeito pós-moderno que não tem mais apenas uma identidade unificada e estável, senão várias identidades contraditórias e, possivelmente, provisórias. A provisoriedade e transitoriedade das identidades são alçadas pelo autor a partir da concepção de que não há uma definição biologicamente atribuída a cada identidade, pois são posicionadas conforme somos representados ou interpelados nas relações com o mundo e isso permite que, em alguns momentos, uma ou mais identidades sejam suspensas e outras fortalecidas, conforme o contexto no qual o sujeito esteja inserido.

Assim, as identidades podem ser definidas em lugares e momentos particulares (WOODWARD, 2000), por exemplo, se pensarmos em identidades nacionais, ser brasileiros pode nos unir em um evento esportivo, mas a identidade nacional também pode ser suspensa em outras ocasiões tal como em uma manifestação da comunidade surda, em que a pauta está centrada nas identidades surdas e ouvintes. Ser surdo, ou ouvinte ou brasileiro podem ser identidades secundárias durante uma Parada do Orgulho LGBT $^{35}$ em que esses indivíduos podem ser observados lado a lado lutando pelo reconhecimento da orientação sexual desse grupo. Isso ocorre porque como sujeitos dessa modernidade tardia somos atravessados por várias identidades que, em alguns momentos, podem inclusive colidir.

Woodward (2000, p. 31) entende que a emergência de novos papéis e identificações sociais tem causado uma crise de identidades, pois "a complexidade da vida moderna exige que assumamos diferentes identidades, mas que podem estar em conflito." Hall (1998) explica que essas identidades podem ser contraditórias, empurrando o sujeito para direções distintas, deslocando as identificações, tornando-as provisórias e transitórias. Com isso, qualquer procura por identidades homogêneas e estáveis seria uma fantasia.

Essa leitura do conceito de identidades surdas sugere, por exemplo, destituir a existência de um "surdo original" ou de "surdo legítimo", na mesma medida em que somos impedidas de compartilhar com Perlin $\left(2016^{36}\right)$ a divisão de identidades surdas em híbridas, incompletas, de

\footnotetext{
${ }^{35}$ LGBT tem sido utilizado para referir a comunidade de lésbicas, gays, bissexuais, travestis, transexuais e transgêneros.

${ }^{36}$ Ressalta-se que a primeira edição da publicação feita por Perlin data do ano de 1998.
} 
transição ou flutuantes ${ }^{37}$. Uma vez que nos ancoramos em Bhabha (2007), para quem o híbrido está na matriz de todas as representações culturais, linguísticas e identitárias, então não seria possível diferenciar o que é original do que é híbrido, pois para esse autor todo elemento fruto desses contextos é originalmente híbrido. E, por conseguinte, se há pouco admitimos com Skliar (2015, p. 11) que "o sujeito contemporâneo não possui uma identidade fixa, estática, centrada, essencial ou permanente”, posto que a “[...] identidade é móvel, descentrada, dinâmica, formada e transformada continuamente [...]", como poderíamos considerar que haja identidades incompletas (tornando implícito que haja identidades completas), transitórias (subentendendo que não sejam todas elas e, sim, somente algumas) ou flutuantes (como se todas não pudessem ser suspensas em momentos específicos)?

Desse modo, ao falar de identidades surdas, comungamos da opinião de Skliar (2016) sobre a necessidade de termos cautela para não adotarmos uma ideologia dominante a qual estamos criticando. E para isso, ao falar dos surdos, caberia nos empenhar para não os traduzir como se fossem somente "[...] surdos homens, brancos de classe média, que frequentam as instituições escolares, que fazem parte dos movimentos de resistência, que lutam pelos seus direitos linguísticos e de cidadania etc.” (SKLIAR, 2016, p. 14). Para esse autor, a configuração do ser surdo integra, também, os surdos oriundos de classes populares, negros, mulheres, meninos de rua e, inclusive, aqueles que ignoram serem surdos.

Em diversas situações, essas múltiplas identidades precisam ser negociadas, uma vez que um mesmo indivíduo pode apresentar mais de uma identidade de baixo prestígio social, ocupando, consequentemente, um local diferenciado nas relações de poder estabelecidas diante dos grupos hegemônicos. Como lidar com a questão de indivíduos surdos que são, por exemplo, simultaneamente, negros, pobres, mulheres, homossexuais e/ou crianças ${ }^{38}$ ? Será que essas múltiplas identidades têm sido consideradas na organização dos processos seletivos envolvendo os cursos de graduação voltados à formação de professores de Libras? Sabe-se que sujeitos

\footnotetext{
${ }^{37}$ Segundo a pesquisadora surda Perlin (2016), é possível enumerar ao menos cinco modelos de identidades, a saber: 1) identidade surda: aqueles que vivenciam o mundo através de experiências visuais e da Libras desde a tenra infância e, geralmente, estão ativamente envolvidos na militância surda; 2 ) identidade surda híbrida: surdos que nasceram ouvintes e, com o tempo, tornaram-se surdos. São sujeitos que ainda interpretam o mundo primeiramente através da Língua Portuguesa e, em seguida, passam suas impressões visuais para a língua de sinais; 3) identidade surda de transição: surdos que foram mantidos sob forte influência da experiência ouvinte e, posteriormente, foram inseridos na comunidade surda; 4 ) identidade surda incompleta: surdos que vivem sob uma ideologia ouvintista latente, orientados com base na cultura dominante, como uma tentativa de reprodução da identidade ouvinte; e 5) identidade surda flutuante: surdos que vivem e se manifestam a partir da hegemonia dos ouvintes. São vistos pela autora como vítimas da ideologia ouvintista, têm um forte desejo de serem ouvintizados, desprezam e negligenciam a cultura e a comunidade surda.

${ }^{38}$ É válido relembrar que em nosso entendimento todas as identidades são híbridas e possuem diferentes modos de serem vivenciadas, ou seja, não há uma única forma de ser surdo, bem como de ser negro, homossexual, criança, entre outras.
} 
surdos e negros ou surdos e índios, por exemplo, carregam múltiplas condições de desvantagens sociais perante o grupo dominante, sofrendo o que Skliar $(2016$, p. 22) chamou de "dupla opressão". Expressão adotada quando se referiu a uma pesquisa relacionada a mulheres surdas e negras norte-americanas que encontravam maior dificuldade para ocupação profissional comparadas aos homens surdos e brancos.

Klein e Formozo (2007), ao analisarem a complexidade desse contexto, abordaram a presença de mulheres surdas no mercado de trabalho no Brasil e concluíram que as mulheres surdas sofrem uma dupla discriminação na vida social e profissional, tendo sido durante muito tempo silenciadas, ora pela condição linguística ora pelo gênero. As autoras ainda destacam que essa conjunção de estudos envolvendo os conceitos de gênero e surdez são ainda bastante recentes no país.

A respeito da combinação de índios surdos, há o estudo da pesquisadora surda Vilhalva (2009) acerca do mapeamento das línguas de sinais emergentes de comunidades linguísticas indígenas do Mato Grosso do Sul. A autora problematiza as singularidades do contexto linguístico de índios surdos inscritos em um espaço de dupla minoria linguística, onde muitas vezes não apresentam o domínio esperado da língua indígena, da Libras e tampouco da Língua Portuguesa, e, portanto, tanto criam um novo espaço, o das línguas de sinais emergentes, como Vilhalva $(2009,2012)$ denominou.

Com efeito, Hall (1998) afirma que, em nosso mundo globalizado, esses cruzamentos se tornam cada vez mais comuns, desestabilizando as identidades culturais até, pouco tempo, consideradas como fixas. Esse pode ser um grande desafio para a escola, uma vez que sendo uma instituição que recebe pessoas com diferentes características individuais, socioeconômicas, religiosas, culturais e, no caso dos surdos, linguísticas, deve estar preparada para acolher e lidar com a heterogeneidade do seu público (PRIETO, 2006).

Além disso, compactuando com Skliar (2003, p. 87), esse pode ser um grande paradoxo para a sociedade e para a instituição escolar, uma vez que "o mesmo sistema, a mesma mesmidade que produz o excluído agora cuidará dele, agora o albergará?”. Esse autor descreve que a classificação de grupos é um ato perverso, pois colabora com a inclusão da "mesmidade" e a exclusão do outro. A perversão na visão de Skliar (2003, p. 66) está, sobretudo, fundamentada na lógica “[...] do só pode ser dentro e do só pode ser fora [...] perversão de rejeitar, impedir, proibir os não espaços, a falta de espaços, os espaços híbridos, as fronteiras, a passagem entre fronteiras, a vida nas fronteiras, os espaços outros.” E, em nossa leitura, estar em uma dupla ou múltipla condição de discriminação é estar em um espaço ainda não traduzido e que precisa de atenção redobrada. Como dito anteriormente, existem diversas formas de se 
vivenciar a surdez, logo, ser um homem surdo, branco de classe média ou alta não deve ser equiparado a ser uma mulher surda, negra de classe baixa.

O autor declara que, por muito tempo, o grupo dos excluídos foi associado tão somente à pobreza, ou seja, os excluídos eram os pobres. Entretanto, tem sido observada uma subcategorização dessa exclusão que, além de ampliar essa lista (agregando imigrantes, mulheres, índios, pobres, deficientes, população em situação de rua, delinquentes, marginais, viciados, gays e lésbicas) permitiu a vários indivíduos da sociedade contemporânea ter “[...] seu próprio fragmento e/ou parcela de exclusão [...]" (SKLIAR, 2003, p. 89). Evidentemente, a fragmentação das identidades pode ser vista como um modo de enfraquecimento das lutas instituídas pelas comunidades discriminadas (ou duplamente discriminadas), pois, aparentemente, geraria brechas pela luta do índio surdo, da mulher surda, do negro surdo etc. No entanto, buscamos aqui, com efeito, desnudar a complexidade dessa constituição identitária deflagrada na pós-modernidade, a qual não podemos permitir que continue sendo homogeneizada ou invisibilizada (problematização essa que retomaremos durante a discussão dos nossos resultados).

De acordo com Boneti (2006), atualmente, os excluídos não podem mais ser vistos como um grupo homogêneo, pois em inúmeras situações congregam grande parte das desvantagens sociais. Barnes (2010), por exemplo, destaca que a pobreza está frequentemente atrelada à deficiência, pois fatores como desnutrição, falta de saneamento básico e condições de trabalho precárias colaboram para o aumento da incidência da deficiência entre a população mais carente. Castel (2011), assim como Boneti (2006) e Barnes (2010), não se refere aos surdos, mas discute sobre a dupla condição de desvantagem quando aborda jovens franceses de periferia e descendentes de imigrantes, que habitam cotidianamente um espaço intersticial "nem dentro nem fora", pois ao mesmo tempo em que são cidadãos e estão inscritos no território francês, percebem o tratamento diferenciado recebido por esta sociedade que, insiste, em desqualificá-los. Nosso olhar converge com Castel (2011), ao pensar que quando sujeitos estão sendo discriminados por estarem em condições de dupla desvantagem, é necessário combatêlas simultaneamente.

Para Castel (2011), ao sofrer de múltiplas desvantagens, a pessoa deve ser auxiliada diferenciadamente, pois apenas, desse modo, será capaz de superar esse contexto de exclusão e, portanto, o autor advoga em prol do que denomina de políticas de discriminação positiva.

Segundo a teoria de Castel (2011), existem duas formas de discriminação, uma positiva e outra negativa. Sob o ponto de vista da discriminação negativa, o sujeito é estigmatizado por uma característica que ele não escolheu, mas que o marca como portador de um defeito que o 
define sempre à margem da sociedade agindo, portanto, como um mecanismo de exclusão. Por outro lado, a discriminação positiva consiste em "[...] fazer mais por aqueles que têm menos" (CASTEL, 2011, p. 13), por meio de práticas suplementares com intuito de (re)integrar a população discriminada ao regime comum. O autor declara que, sob essa linha de pensamento, não seria discriminatório, por exemplo:

[...] adotar uma pedagogia especial para alunos que precisam de reforço escolar a fim de que não fiquem reprovados, ou oferecer formações profissionais adaptadas aos trabalhadores pouco qualificados para evitar que eles corram o risco de ficar eternamente desempregados. Pode ser útil e até mesmo indispensável, tomar como alvo as populações marcadas por uma diferença que para elas é uma desvantagem, visando reduzir ou anular esta diferença. (CASTEL, 2011, p. 13).

Assim, a discriminação positiva justificaria o tratamento diferenciado a determinados grupos que se encontram em desvantagem social, como uma estratégia de se igualar às condições de competição desses sujeitos em diferentes esferas da sociedade, tais como na escola, na universidade e no mercado de trabalho. Ao discutir a proposta de uma escola justa, Dubet (2004) também se apoia no princípio da discriminação positiva por entender os limites do ideal meritocrático tão apregoado e vinculado ao conceito de igualdade de oportunidades.

Segundo esse autor, a meritocracia consiste em dar (e exigir) a mesma coisa a (de) todos, tal como em uma competição, mas para isso deveria, inicialmente, garantir que os competidores dominem as regras do jogo e que o terreno seja igual para todos, incluindo juízes imparciais e sistemas transparentes, realidade que ainda não se sustenta no atual modelo escolar. Sob essa ótica, Dubet (2004, p. 546) assume que:

[...] em muitos casos a justiça consiste em ultrapassar a "igualdade pura". Se quisermos que as mulheres entrem na política, será preciso que criemos quotas; se desejarmos que os bons alunos dos bairros populares façam bons estudos, será preciso que tenham preparação específica; se quisermos que todos saibam ler, será preciso maior tempo de aprendizagem em algumas escolas; se quisermos que os alunos tenham acesso à alta cultura, será preciso organizar clubes de teatro e cinema para aqueles que têm apenas uma televisão em casa...

Logo, não haverá escola ou sociedade justa sem a adoção de medidas de discriminação positiva que equilibrem a balança daqueles que têm sofrido com a discriminação negativa. Uma análise semelhante ainda é contemplada por Kerstenetzky (2006) ao defender que em sociedades desiguais, não há como promover o acesso de alguns aos direitos universalizados, 
entre estes a educação, sem a adoção da focalização. Para essa autora, frequentemente, a “focalização como ação reparatória” (KERSTENETZKY, 2006, p. 570) se faz necessária:

[...] para restituir a grupos sociais o acesso efetivo a direitos universais formalmente iguais - acesso que teria sido perdido como resultado de injustiças passadas, em virtude, por exemplo, de desiguais oportunidades de realização de gerações passadas que se transmitiram às presentes na perpetuação da desigualdade de recursos e capacidades. Sem a ação/política/programa, focalizados nesses grupos, aqueles direitos são letra morta ou se cumprirão apenas em um horizonte temporal muito distante. Em certo sentido, essas ações complementariam políticas públicas universais justificadas por uma noção de direitos sociais, como, por exemplo, educação e saúde universais, afeiçoando-se à sua lógica, na medida em que diminuiriam as distâncias que normalmente tornam irrealizável a noção de igualdade de oportunidades embutida nesses direitos. (KERSTENETZKY, 2006, p. 570).

Emprestamos as palavras da autora para entender que diante do contexto histórico de discriminação vivenciado por alguns grupos, e aqui nos interessa pensar nos surdos (e negros de classe baixa e oriundos da escola pública), bem como na desigualdade de acesso à educação superior e mesmo na sua inserção ao mercado de trabalho, direitos estabelecidos na esfera dos direitos universais, é pertinente a adoção de uma política focalizada de forma complementar à universal, tal como a prioridade para candidatos surdos (BRASIL, 2005) e a reserva de vagas para estudantes de oriundos de escolas públicas, negros, pardos ou indígenas e com baixa condição econômica (BRASIL, 2012a). Utilizando as palavras de Dhanda (2008) seria como promover uma dupla compensação àqueles que se encontram duplamente discriminados. Entretanto, como dito anteriormente, não ignoramos que a implantação de medidas nesse âmbito pode gerar significativa polêmica, uma vez que, apesar do objetivo ser igualar as oportunidades, essas ações podem ser utilizadas para se acentuar as diferenças que produzem a discriminação negativa (SKLIAR, 2003; CASTEL, 2011).

Essas questões serão retomadas e demonstradas durante a análise dos nossos dados, mas, neste momento, importa destacar que a ótica da surdez como diferença (SKLIAR, 2016) requer o reconhecimento dessas especificidades identitárias que o compõe, evitando essencializações ou unificações que destoam da composição do sujeito pós-moderno (HALL, 1998, 2000), principalmente de essências biológicas que interpretem o surdo pelas lentes do deficientismo (BEHARES, 2015). Afinal, uma das principais defesas da surdez enquanto diferença consiste no seu distanciamento do discurso da deficiência, deslocando seu debate para os contextos bilíngues minoritários/minoritarizados, tópico de discussão que abordaremos na sequência. 


\subsection{O SURDO NO CONTEXTO DA EDUCAÇÃO BILÍNGUE DE GRUPOS MINORITÁRIOS/MINORITARIZADOS}

Uma das implicações engendradas em nossa afiliação a uma leitura da surdez sob o prisma da diferença consiste em nos desviarmos dos discursos clínico-patológicos orientados pelo "corpo danificado", como se refere Perlin (2016), para assumirmos o surdo como bilíngue (ou multilíngue) e, portanto, inscrito no debate dos contextos bi/multilíngues minoritários/minoritarizados. Antes de serem considerados como pertencentes a uma minoria linguística (CAVALCANTI, 1999; SILVA, 2005; FAVORITO, 2006; GESSER, 2006; KUMADA, 2012; KUMADA; CAVALCANI, 2014), os surdos já foram identificados como grupos étnicos e grupos de experiência (SKLIAR, 1998; BEHARES, 2015 39). Entretanto, estamos preferindo aqui o termo minoritários/minoritarizados em lugar de minorias e explicaremos os motivos.

De acordo com Skutnabb-Kangas (1981), o conceito de bilinguismo tem sido, tradicionalmente, associado aos grupos linguísticos denominados de minorias por serem social e politicamente oprimidos, mas que não representam sempre, necessariamente, uma minoria numérica. Cavalcanti (1999) problematizou esse conceito de minorias no Brasil ${ }^{40}$, denunciando que se fossem somadas as comunidades de imigrantes, as comunidades surdas, as nações indígenas e as comunidades de falantes de variedades desprestigiadas da Língua Portuguesa, por extensão, pensando estatisticamente, obteríamos uma maioria. Neste sentido, as "minorias" linguísticas não poderiam ser consideradas verdadeiramente "minorias" do ponto de vista matemático, mas, na realidade, contextos minoritários e/ou que são minoritarizados por estarem distantes das fontes de poder hegemônico, embora, algumas vezes, possam representar comunidades majoritárias em relação à sociedade ou aos grupos dominantes ${ }^{41}$ (CAVALCANTI, 1999, 2011; CÉSAR; CAVALCANTI, 2007).

\footnotetext{
${ }^{39}$ Segundo Behares (2015), a princípio, na década de 1980, o agrupamento das pessoas surdas chegou a ser classificado como "grupo étnico", mas como o conceito de etnia pressupunha um traço ou atributo distintivo para promover aos seus membros o autorreconhecimento, bem como a diferenciação de outros grupos, o autor rejeitou essa classificação, afirmando que a aproximação dos surdos não se guiava por um traço ou atributo, mas pela língua de sinais. Neste aspecto, propôs analisar os surdos como "grupos de experiência", tal como os homossexuais que não nascem em seu grupo de pertencimento, mas se organizam nele em virtude de uma experiência em comum partilhada que permite o desenvolvimento de uma identidade. Entretanto, com o tempo, o autor afirma que mesmo a expressão "grupo de experiências" também era insuficiente para explicar a complexidade desse contexto.

${ }^{40}$ Outra autora que defende esse ponto de vista é Altenhofen (2013, p. 94), ao identificar que existe uma gama de expressões utilizadas para "[...] designar línguas que existem à margem (ou a sombra) de uma língua dominante [...]", entre elas é possível elencar "língua periférica", "língua marginal", "línguas ameaçadas", "língua da comunidade" e "dialeto".

${ }^{41}$ Em estudo mais recente, Cavalcanti (2011, p. 176) propõe ainda pensar nesses contextos bilíngues como minoritários, minoritarizados e "invisibilizados", entendendo que a invisibilização consiste no desconhecimento da complexidade intrínseca a esses contextos. Concordamos com a autora, mas neste trabalho manteremos apenas
} 
Uma visão semelhante da inadequação do termo minorias é observada nos estudos feitos por Skliar (1998, 2016), para quem esse conceito não se aplica de forma quantitativa, mas, qualitativa. Para demonstrar essa análise o autor propõe pensar sobre diferentes contextos de minorias, por exemplo, na Inglaterra onde cerca de 50 mil surdos se comunicam pela língua de sinais britânica, número quase equiparado aos falantes do galês. Apesar disso, o tratamento a esses dois grupos, no tocante à organização política e educacional do país, não se assemelha.

Do mesmo modo, embora a Língua de Sinais Americana represente a terceira língua de maior uso nos Estados Unidos, o autor declara que o status social, acadêmico e linguístico da referida língua de sinais não é o mesmo daquele atribuído ao francês ou ao espanhol. Logo, para Skliar (1998, 2016), o que está em pauta não é a quantidade de falantes que compõe a minoria, mas as relações assimétricas e hierárquicas de poder que permeiam esses contextos e que devem ser problematizadas, contudo, sem ser sobre a maioria ouvinte versus a minoria surda.

Com efeito, não apenas o cenário da surdez, bem como em todos os contextos bilíngues de minorias (e aqui compreendemos o conceito de minorias do ponto de vista qualitativo) sofrem certo desprestígio (SKUTNABB-KANGAS, 1981; CAVALCANTI, 1999). Para entendermos as raízes da desvalorização desse fenômeno linguístico, primeiramente, cumpre situar que o bilinguismo nem sempre foi estimulado pela sociedade, pois, no passado, estava associado somente às comunidades linguísticas oprimidas e minoritarizadas, especialmente as indígenas e de imigrantes. Estes por se encontrarem, muitas vezes, na posição de colonizados eram cobrados a assimilar a língua e a cultura do grupo majoritário, promovendo a ideia de existência de uma única língua que unificasse a nação (SKUTNABB-KANGAS, 1981).

Infelizmente, não podemos negar que esse processo de apagamento das línguas minoritárias funcionou, tal como é possível observar no exemplo das línguas indígenas brasileiras, pois se verificarmos o seu inventário linguístico constataremos que, conforme Altenhofen (2013), na época de Cabral estimava-se a presença de 1.078 línguas indígenas e, atualmente, os dados revelam a existência de aproximadamente 219. Contudo, a supressão dessas línguas foi feita a base de intensa coerção ideológica, recorrendo com frequência, inclusive, à violência física (MAHER, 1998; OLIVEIRA, 2003).

Skutnabb-Kangas (1981) retrata que as violências física e psicológica são mecanismos vislumbrados em diversas experiências educacionais com bilinguismo de minorias, pois nos

a expressão minoritários/minoritarizados, tal como utilizado em trabalhos anteriores (KUMADA, 2012; KUMADA; CAVALCANTI, 2014). 
países em que as punições corporais são (ou passaram a ser) ilegais, foram utilizados outros métodos como o isolamento das crianças de seus grupos linguísticos, ameaças psicológicas e instrumentos baseados na promoção de sentimentos de vergonha e culpa ${ }^{42}$. A autora enfatiza que, em defesa dessa linha de pensamento, as pesquisas produzidas sobre bilinguismo abordavam os diversos prejuízos que esse fenômeno poderia acarretar, especialmente, no desenvolvimento linguístico e educacional, bem como, futuramente, em sua inserção profissional. Emprestando suas palavras, o bilinguismo costumava ser associado: “[...] with poverty, powerlessness, and subordinate social positions [...]. Bilinguism, then, has come to be something you 'get away from' if you succeed in climbing the social ladder." 43 (SKUTNABBKANGAS, 1981, p. 67).

Não foi isso que também testemunhamos no passado e ainda no presente quando olhamos para o contexto bilíngue dos surdos? Acreditamos que não faltam indícios, inclusive de violência física, para tornar essa resposta afirmativa. Carvalho (2007) narra que o famoso médico francês Jean Itard não aceitava a língua de sinais e, no início do século XIX, dedicouse à cura da surdez realizando inúmeras experiências com surdos, aplicando cargas elétricas, efetuando sangramentos, perfurando tímpanos e inserindo cateteres nos ouvidos. Do mesmo modo, Gesser (2012) compartilha relatos de surdos brasileiros que, durante sua trajetória escolar, nas décadas de 1980 e 1990, tiveram as mãos amarradas como estratégia para impedilos de as utilizarem na comunicação, pois se acreditava que, dessa maneira, abandonariam a língua de sinais, sendo forçados a usar a modalidade oral da Língua Portuguesa.

Além disso, se pensarmos em estratégias de isolamento das crianças surdas de seus grupos linguísticos como uma violência psicológica, não seria a mesma coisa que acontece quando inserimos as crianças surdas nas escolas regulares, espaços em que, na maioria das vezes, não há pares surdos nem usuários da Libras com quem possam estabelecer diálogos ou sentimentos de identificação surda? Apesar de não descrever especificamente o contexto da surdez, ao relatar sobre a separação escolar de crianças perante seus grupos linguísticos como um mecanismo de violência psicológica, Skutnabb-Kangas (1981) assegura que a finalidade desse isolamento consiste em fazer com que tenham pouco ou nenhum contato com sua própria

\footnotetext{
${ }^{42}$ Martin-Jones e Romaine (1986), ao discutirem sobre o contexto de sujeitos bilíngues em finlandês e sueco de Tornedal descrevem que eles sofriam vários processos de discriminação sendo, muitas vezes, considerados semilíngues e, por essa condição, apresentavam prejuízos cognitivos e acadêmicos. Stroud (2004, p. 199), também discute o contexto sueco, mas sob a realidade dos falantes de Rinkeby Swedish, um sistema linguístico altamente estigmatizado, sendo os seus falantes associados a diversos xingamentos que, entre outras formas de denegrir a imagem deles, conotam, por exemplo, que eles possuem doenças contagiosas.

${ }^{43} \mathrm{Ou}$ seja, o bilinguismo costumava ser associado "[...] à pobreza, à impotência e às posições sociais subalternas [...]. Bilinguismo, então, foi concebido como algo que se deveria evitar, caso tenha intenções de ascender socialmente." (SKUTNABB-KANGAS, 1981, p. 67, tradução nossa).
} 
cultura, história, língua e tradições. Assim, por não saberem nada a respeito, quando se encontrarem com o seu grupo linguístico se sentirão strangers (que poderia ser traduzido como estranhas ou estrangeiras) diante daquilo que deveria ser a sua própria cultura.

Como pode ser visto, são procedimentos de marginalização, discriminação e invisibilização das línguas minoritárias/minoritarizadas (e aqui nos interessa particularmente a situação da Libras) que continuam sendo aplicados, embora, atualmente, talvez de forma mais velada. Isso porque, muitos desses grupos conseguiram se organizar formulando e reivindicando demandas linguísticas, culturais e políticas para seus contextos, sobretudo, no que se refere à educação linguística de suas crianças (SKUTNABB-KANGAS, 1981). No Brasil, esse movimento de reconhecimento de uma educação bilíngue diferenciada para as “minorias" começou com as comunidades indígenas (MAHER, 1998; OLIVEIRA, 2003), por intermédio da garantia de processos próprios de aprendizagem incluindo o uso de suas línguas como um direito assegurado no artigo 210 da CF/88 (BRASIL, 1988) ${ }^{44}$.

Anos mais tarde, as comunidades surdas também alcançaram o direito de uma educação bilíngue, por meio da oficialização da Libras como sua L1 e da Língua Portuguesa como L2 (BRASIL, 2002, 2005). Aos surdos passou a ser juridicamente assegurado nos artigos 22 e 23 do Decreto $n^{0}$ 5.626/05 (BRASIL, 2005), dentre outras disposições, que as instituições federais de ensino promovam a esse público, desde a educação infantil, escolas e classes de educação bilíngue com professores bilíngues; escolas comuns da rede regular com professores cientes das singularidades linguísticas dos surdos, bem como a presença de tradutores e intérpretes de Libras; e, no âmbito da educação superior, além de tradutores e intérpretes de Libras, a oferta de equipamentos de acesso à informação, comunicação e educação.

Ademais, cabe salientar que o Plano Nacional de Educação (PNE), aprovado pela Lei $\mathrm{n}^{\mathrm{o}}$ 13.005/14, de 25 de junho de 2014, reforça as determinações do citado decreto, estabelecendo como uma de suas estratégias:

4.7) garantir a oferta de educação bilíngue, em Língua Brasileira de Sinais LIBRAS como primeira língua e na modalidade escrita da Língua Portuguesa como segunda língua, aos(às) alunos(as) surdos[as] e com deficiência auditiva de 0 (zero) a 17 (dezessete) anos, em escolas e classes bilíngues e em escolas inclusivas, nos termos do art. 22 do Decreto no 5.626, de 22 de dezembro de 2005, e dos arts. 24 e 30 da Convenção sobre os Direitos das Pessoas com

\footnotetext{
44 Segundo Oliveira (2003), a conquista dos direitos em prol das nações indígenas brasileiras propiciou a construção de uma educação indígena e a criação de mais de 1.600 escolas neste segmento, espalhadas em quase todos os estados do país. Maher (1998) complementa que, com isso, emergiu o interesse desses povos por desenvolver pesquisas para a revitalização e manutenção das culturas e línguas indígenas.
} 
Deficiência, bem como a adoção do Sistema Braille de leitura para cegos e surdos-cegos; (BRASIL, 2014, p. 3).

No entanto, apesar do reconhecimento legal do ordenamento jurídico concernente à condição bilíngue da educação de surdos, permanece a dificuldade de equiparar o bilinguismo em Libras ao valor social e incentivos atribuídos ao bilinguismo de elite. Conceituamos bilinguismo de elite ancorados em Skutnabb-Kangas (1981), para quem o bilinguismo pode ser classificado como coletivo (quando ocorre em países que são bilíngues ou multilíngues ${ }^{45}$ ) ou individual. No âmbito do bilinguismo individual, para refletir sobre o seu processo educacional, a autora divide em quatro grandes grupos: 1) bilinguismo de elite; 2) crianças de línguas majoritárias; 3) crianças de famílias bilíngues; e 4) crianças de minorias linguísticas.

Neste trabalho, interessa-nos comparar, especialmente, o bilinguismo de elite e o de crianças de minorias linguísticas ${ }^{46}$, bastante comuns no país. O bilinguismo de elite é composto por sujeitos que optam voluntariamente (ou por escolha de seus pais) pela aquisição de outra língua, sem que isso imponha o abandono de sua L1, pelo contrário, é incentivado que o indivíduo desenvolva ao máximo sua proficiência em ambos os sistemas linguísticos. Assim, quando, por exemplo, é encorajado a ingressar em um colégio bilíngue ou a realizar uma viagem para outro país, o aluno sabe que poderá utilizar sua L1 quando retornar ou se encontrar com seus pares, portanto, há um menor nível de pressão seja interna ou externa. As representações a esse modelo de bilinguismo são positivas e estão atreladas ao enriquecimento do nível individual (SKUTNABB-KANGAS, 1981). Cavalcanti (1999, p. 387) complementa ainda que o bilinguismo de elite está associado "[...] a línguas de prestígio tanto internacional como nacionalmente", sendo incluídas nessa perspectiva o inglês, o alemão, o francês, o espanhol, entre outras.

$\mathrm{Na}$ outra ponta, encontra-se o bilinguismo de minorias linguísticas (ou de comunidades linguísticas minoritárias/minoritarizadas), no qual os alunos são sujeitados a uma pressão social, muitas vezes, da própria família para se tornarem bilíngues, inclusive porque sua L1 tem

\footnotetext{
${ }^{45}$ De acordo com Skutnabb-Kangas (1981), existem cerca de 3 mil línguas diferentes no mundo e pouco menos de 200 países, ou seja, estima-se que haja mais países multilíngues que monolíngues no globo denotando que o multilinguismo não é uma exceção, é mais comum do que se imagina. Inclusive no Brasil em que se paira o mito de ser um país onde se fala o português do Oiapoque ao Chuí, conforme Maher (2013), além das línguas indígenas, existem aproximadamente 40 línguas de imigração e pelo menos duas línguas de sinais (a Libras e a língua de sinais Kaapor brasileira).

${ }^{46}$ Por não ser o nosso foco, cumpre apenas explicitar que o bilinguismo aplicado às crianças de línguas majoritárias ocorre quando se aprende uma língua estrangeira na escola ou quando a L1 já apresenta um alto status e, por escolha própria, o sujeito decide aprender outra língua, inclusive línguas de grupos minoritários, como é o caso, por exemplo, dos profissionais que aprendem a língua de seus alunos bilíngues de minorias para, assim, ensinarlhes a língua majoritária. Referente às crianças de famílias bilíngues, como a própria denominação sugere, tratase de situações em que os pais apresentam sistemas linguísticos diferentes (SKUTNABB-KANGAS, 1981).
} 
direitos restritos e o domínio da L2 representa a única chance de obter êxito educacional e econômico (SKUTNABB-KANGAS, 1981). Como envolve uma língua minoritária/ minoritarizada sem prestígio social, há um menor investimento de pesquisas nessa área e, consequentemente, os materiais e métodos utilizados são inferiores aos encontrados nas práticas bilíngues vinculadas às línguas de elite. No entanto, se houver uma falha nesse aprendizado os riscos e as consequências para o sujeito são mais graves comparados ao grupo alocado no bilinguismo de elite, pois, segundo Skutnabb-Kangas (1981, p. 79):

If the child becomes almost monolingual or very dominant in her own language, then most future educational opportunities will be closed to her. She will not be able to compete in the labour market with other young people from the majority. Her chances of sharing in the life of the larger community and influencing it will be severely limited. It will also be impossible for her to try to improve the situation of her own group, together with others, to demand linguistic and other rights for her group $[\ldots]^{47}$.

Os impactos discorridos pela autora soam familiares ao refletirmos sobre a educação bilíngue de surdos, uma vez que se a criança surda não adquirir um alto grau de proficiência na língua majoritária do país, no nosso caso, o português, poderá apresentar dificuldades para dar continuidade em seus estudos na educação superior, para se inserir no mercado de trabalho e, inclusive, para realizar mais contribuições no que se refere à ampliação dos direitos para o seu grupo, seja no âmbito linguístico, educacional, político, cultural ou identitário.

No processo de educação formal, segundo Maher (2007), a diferença do bilinguismo no contexto das pessoas surdas (ou de outros grupos minoritários/minoritarizados) para o bilinguismo envolvendo uma língua majoritária é que para os surdos essa condição é compulsória, enquanto para a maioria das pessoas ouvintes brasileiras a escolha é facultativa. Inclusive nos casos em que a escola prevê a obrigatoriedade de os alunos cursarem em seu currículo disciplinas como o inglês ou o espanhol, a autora destaca que esse processo mantém a língua materna do aluno ouvinte como a língua de instrução na sala de aula, quando a mesma conduta não é efetivamente assegurada aos aprendizes surdos. Por essa razão, a autora afirma que ao índio, bem como aos surdos, imigrantes e seus descendentes não há outra opção, eles

\footnotetext{
${ }^{47}$ Se a criança se tornar monolíngue ou com muito domínio em sua própria língua, então a maior parte das oportunidades educacionais futuras se fecharão para ela. Ela não será capaz de competir no mercado de trabalho com outros jovens da comunidade majoritária. Suas chances de participação na vida da comunidade majoritária e sua influência nela serão severamente limitadas. Com isso, também será impossível para ela tentar melhorar a situação de seu próprio grupo, juntamente com outros, por demandas linguísticas e outros direitos para seu grupo [...] (SKUTNABB-KANGAS, 1981, p. 79, tradução nossa).
} 
são obrigados a se tornarem bilíngues e isso ilustra as relações desiguais de poder presentes na “[...] escolarização de minorias - não só do Brasil, mas no mundo todo.” (MAHER, 2007, p. 69). Algo que na leitura dessa autora não se pode perder de vista durante a reflexão teórica, a prática educacional e a formação de professores para atuarem no segmento.

Assim, julgamos que o conhecimento dessa discussão é de suma relevância para se pensar a formação do professor de Libras, uma vez que o ensino dessa língua está inserido em um contexto bilíngue de ensino de línguas que são marginalizadas (ALTENHOFEN, 2013) e minoritarizadas (CAVALCANTI, 2011). Diante disso, a educação bilíngue assume diferentes facetas, pois, em concordância com Maher (2007), ao lidar com o bilinguismo envolvendo línguas de prestígio como o português e o inglês, a escola assim como grande parte da sociedade tende a incentivar essa prática, o que justifica o significativo aumento no país de escolas (particulares) bilíngues em inglês ou em alemão. Mas, quando as línguas em jogo são de caráter não prestigioso, como são consideradas a Libras e as línguas indígenas, “[...] o bilinguismo é quase sempre visto como um 'problema' a ser erradicado" (MAHER, 2007, p. 69) e isso remonta às implicações do modelo de educação bilíngue praticado pelas escolas.

Para Maher (2007) e Hamel (1989), quando o bilinguismo de minorias, termo utilizado pelos autores, está em questão, geralmente, o modelo educacional perseguido, de modo explícito ou implícito, será o que a literatura convencionou chamar de modelo assimilacionista de submersão. De acordo com Maher (2007, p. 70):

Esse modelo apregoa a inclusão do aluno bilíngue em uma sala de aula
monolíngue: não tendo com quem interagir em sua língua materna, ele será
forçado a abandoná-la e a aprender a língua portuguesa. Além de
extremamente desrespeitoso e violento para com o aluno, teóricos
consagrados da área de Educação Bilíngue vêm, já há algum tempo, alertando
para o fato de que esse modelo é, além disto, bastante ineficiente: a
aprendizagem da língua majoritária não acontece nos moldes previstos. As
evidências empíricas apontam justamente para o contrário: quanto maior o
investimento pedagógico na língua materna, mais facilidade terá o aluno de se
desenvolver em sua segunda língua. No entanto, foi justamente esse o modelo
adotado por algumas missões religiosas e órgãos do governo brasileiro junto
aos povos indígenas durante anos a fio. E é o que está ocorrendo atualmente
com a inclusão das crianças e jovens surdos nas escolares regulares de ensino.

Conforme sublinhado pela autora, o modelo assimilacionista de submersão tem sido implementado na educação de surdos sob a imposição de uma educação monolíngue em Língua Portuguesa. A respeito dos programas de submersão, Martin-Jones e Romaine (1986, p. 27) e Favorito (2006, p. 109) mencionam que são conhecidos pelo bordão sink or swim ou "afunde ou nade", visto que as crianças são alocadas em salas de aula junto com falantes nativos da 
língua de instrução e, por consequência, sujeitadas às condições de ensino e aprendizagem que não correspondem ao processo da instrução de uma L2.

Maher (2007) destaca ainda a existência do modelo assimilacionista de transição, no qual a língua minoritária é aceita nos anos iniciais, sobretudo, na alfabetização, até ser, posteriormente, excluída do currículo escolar. Favorito (2006, p. 109) descreve esse programa como “[...] uma versão mais sofisticada da submersão direta." Segundo Hamel (1989), nesse modelo de bilinguismo, os alunos não recebem nenhum apoio curricular específico, pois a escola almeja a transição da língua minoritária para a L2. Em alguns casos, o autor declara ser comum aceitar, inicialmente, a língua materna do aluno utilizando-a como uma "ponte" (HAMEL, 1989) para o ensino da L2. Contudo, assim que esse domínio é alcançado, rompe-se com a relação entre a L1 do aluno. É o que Silva (2005) observou em sua pesquisa em contextos de educação de surdos, quando a Libras era aceita até o período de alfabetização, sendo a partir de tal momento estabelecida a comunicação apenas pela Língua Portuguesa em sua modalidade escrita. Segundo a autora, a Libras usada como uma "ponte" para se ensinar a escrita era, posteriormente, abandonada (SILVA, 2005).

Para Maher (2007, p. 71), em termos sociolinguísticos, o modelo assimilacionista de transição propõe um bilinguismo subtrativo, cujo principal objetivo é “[...] retirar a língua materna do repertório do falante $[\ldots]$ ”, pois “[...] o aluno começa sua escolarização monolíngue na língua minoritária, passa para um bilinguismo transitório e termina monolíngue na segunda língua, na língua portuguesa." Hamel (1989, p. 39-40) propõe que o modelo de bilinguismo de submersão, em alguns casos, também pode ser considerado “[...] un bilingüismo substractivo, no enriquedor, que se caracteriza por serias deficiencias, especialmente, académicocognoscitivas, en ambas lenguas." 48 Segundo esse autor, nem todos os programas de submersão preconizam o abandono da língua materna do aluno, nesse caso Hamel (1989) os chama de "submersão relativa", embora nessa situação seja determinado à língua minoritária um espaço reduzido na sua educação.

Na leitura de Favorito (2006), a questão central consiste no fato de grande parte desses programas corroborarem, de alguma forma, para se perpetuar a imagem dos bilíngues de "minorias" como "deficientes" ou menos capazes, e aqui não estamos nos referindo apenas aos surdos e a já naturalizada associação dele à falta de audição, mas à ideia de "deficiência" advinda da pobreza, da diferença cultural ou de um domínio precário na L2 e até na L1.

\footnotetext{
48 “[...] um bilinguismo subtrativo, não enriquecedor, que se caracteriza por sérias deficiências, especialmente acadêmico-cognitivas, em ambas as línguas.” (HAMEL, 1989, p. 39-40, tradução nossa).
} 
Para romper com esses programas vinculados a um bilinguismo subtrativo, Maher (2007) apoia o modelo de enriquecimento linguístico, no qual a língua minoritária se constitui como língua de instrução durante todo o processo de escolarização, promovendo com isso um bilinguismo aditivo, no qual " [...] a língua portuguesa deve ser adicionada ao repertório comunicativo do aluno, sem, contudo, deixar de se investir no aumento da competência do uso em sua língua materna.” (MAHER, 2007, p. 71-72). Segundo Hamel (1989), esse é um modelo muito bem-sucedido e ocorre, predominantemente, no contexto bilíngue de línguas de prestígio como, por exemplo, no Canadá.

No entanto, quando olhamos para a realidade da educação bilíngue de surdos no país, ainda não verificamos avanços neste sentido. Os modelos que imperam nesse cenário continuam relegando pouco ou nenhum espaço para o aprimoramento da Libras, passando a maior parte do tempo dedicados ao ensino do português, que também não tem logrado sucesso. Isso porque, especialmente no caso das crianças surdas, conforme Favorito (2006, p. 110), tratase de um círculo vicioso, pois "como as escolas falham em dar suporte a L1 dos alunos, suas habilidades nesta podem ser frequentemente pobres, como é o caso de muitos alunos surdos que, oriundos de lares ouvintes, não tiveram a chance de conviver com seus pares." Sem a aquisição e fortalecimento da L1, consequentemente, eles não progridem satisfatoriamente na língua majoritária e são, muitas vezes, caracterizados como "semilíngues", por não demonstrarem o esperado ou equilibrado domínio na L1 e na L2. Trataremos a seguir sobre esse conceito, pois nossa crítica a este fundamenta a noção de bilinguismo e multilinguismo com a qual nos alinhamos.

\subsubsection{Uma compreensão ampliada a respeito dos conceitos de língua e bi/multiliguismo}

Autores do campo da Linguística Aplicada como, por exemplo, Silva (2005, 2008), Gesser (2006), Kumada (2012), Silva e Kumada (2013), Kumada e Cavalcanti (2014) discutem a necessidade de se desconstruir as noções de semilinguismo no campo da surdez, o que está acompanhado de uma leitura ampliada dos conceitos de língua, bilinguismo e/ou multilinguismo (CÉSAR; CAVALCANTI, 2007).

De acordo com Silva (2008) naturalizou-se no contexto da educação de surdos o discurso de que os sujeitos surdos incapazes de apresentar competências linguísticas na Libras e na Língua Portuguesa são sujeitos “sem língua”. Na mesma direção, Kumada (2012) reuniu representações de familiares, profissionais (surdos e ouvintes) e estagiários participantes de um programa de apoio escolar bilíngue para surdos que evidenciaram essa realidade, sobretudo, no 
que se refere aos surdos oriundos de famílias ouvintes que ingressam na escola sem a constituição de um sistema linguístico legitimado pela sociedade, a saber: a Língua Portuguesa ou a Libras.

Para entender melhor esse contexto é necessário considerar o conhecimento difundido na área de que mais de 90\% das crianças surdas nascem em lares ouvintes (SACKS, 1998; REILY, 2004; BEHARES, 2015). Essa realidade é essencial para situar o processo de constituição linguística da maioria dos sujeitos surdos, pois a notícia da surdez é quase sempre recebida pela família como a perda do filho "saudável" idealizado e, portanto, ouvinte. Françoso (2003) analisa que o sentimento de perda pode ser comparado a um período de luto com o qual os familiares ouvintes chegam a conviver por anos, gerenciando emoções como, por exemplo, culpa, negação, depressão, confusão e inadequação. Para esses familiares que sabem, geralmente, pouco ou nada sobre a surdez, o diagnóstico e as primeiras orientações são feitos pela área clínica que tem, como já sabemos, a tendência de declinar pela abordagem oralista fazendo com que os pais se agarrem na promessa da "cura da surdez" e, por conseguinte, normalização do surdo.

Sendo assim, a maioria dos pais desconhece a Libras e quando percebem que a oralidade é insuficiente para se estabelecer comunicações efetivas com o filho surdo, naturalmente, produzem uma alternativa que é descrita pelos estudiosos através de várias denominações: simbolismo esotérico (TERVOORT, 1961; BEHARES, 1997, 2015), embrião de linguagem ou linguagem umbilical (LIMA, 2004), gestos (PEREIRA, 1989; ALBRES, 2005), mímicas (LIMA, 2004), língua de sinais primária, língua de sinais emergente ou pidgin (SOUZA; SEGALA, 2009; VILHALVA, 2009) e línguas de sinais caseiras (SILVA, 2008; GESSER, 2006; KUMADA, 2012; SILVA; KUMADA, 2013; KUMADA; CAVALCANTI, 2014).

Na década de 1960, destaca-se o trabalho de Tervoort (1961), provavelmente o primeiro a observar que nas comunicações privadas entre crianças surdas com familiares e profissionais, utiliza-se uma gama de recursos, tais como a fala, os apontamentos, a datilologia, os gestos, os sinais formalizados pelas comunidades surdas, a mímica etc. Para esse autor, é indubitável o potencial linguístico presente nessa comunicação a qual ele conceituou como simbolismo esotérico, e que, segundo Behares (1997), Silva (2005, 2008) e Kumada (2012), não recebeu a devida atenção dentro dos estudos linguísticos fomentados no campo da surdez, pois inicialmente as produções literárias desse âmbito estavam mais voltadas para o fortalecimento da Libras e, neste viés, quaisquer mesclas poderiam enfraquecer esse processo de legitimação.

Através da análise de depoimentos de participantes surdos e ouvintes, Kumada (2012) concebe que as línguas de sinais caseiras são constituídas no campo das ambivalências e 
contraditoriedades (tal como o terceiro espaço ${ }^{49}$ de Bhabha, 2007), podendo ser consideradas limitadas a contextos familiares ou a interlocutores específicos e, ao mesmo tempo, funcionais para esses contextos e usuários. A conclusão de seu trabalho infere a necessidade de compactuar com Pereira (1989) e McCleary e Viotti (2011) e admitir que os gestos e a gestualidade carecem de maior atenção no campo dos estudos linguísticos da língua de sinais, tal como já têm sido reconhecidos na linguística das línguas orais.

O reconhecimento e a valorização dos gestos (aquilo que não é aceito como Libras) ou da(s) língua(s) que o surdo traz de casa são importantes para desnaturalizar a recorrência do termo "sem língua", pois a noção de semilinguismo, conforme Martin-Jones ${ }^{50}$ e Romaine (1986) além de atribuir conotações negativas aos falantes, induz ao erro ou a uma visão equivocada do que constitui a natureza da linguagem e a competência de uma língua.

Segundo as autoras, o termo começou a ser difundido no debate referente à competência linguística (e cognitiva ${ }^{51}$ ) de crianças bilíngues de minorias quando eram comparadas aos falantes monolíngues nativos, mas surgiu como uma crítica a essa concepção e, erroneamente, passou a circular com uma interpretação deturpada da discussão original (MARTIN-JONES; ROMAINE, 1986). Quando se fala sobre semilinguismo, a proposta não é legitimar a prática desse termo, mas trazer à tona os equívocos introjetados nessa concepção, pois um dos principais prejuízos, conforme Martin-Jones e Romaine (1986, p. 32) é utilizá-lo para nutrir "[...] the belief that there is such a thing as an ideal, fully competent monolingual or bilingual speaker who has a full or complet version of a language." 52

Para Skutnabb-Kangas (1981, p. 35) o erro reside em tentar mensurar o sujeito bilíngue projetando nele a soma de dois sujeitos monolíngues considerados "completos", pois no caso do indivíduo apresentar um desempenho insatisfatório da norma monolíngue, ele seria visto como doubly semilingual, ou seja, um duplo semilíngue. Para ilustrar essa passagem,

\footnotetext{
${ }^{49}$ Terceiro espaço ou espaço intersticial, grosso modo, desvela um lugar de hibridismo e ambivalências, do novo, de "nem um e nem outro" (BHABHA, 2007, p. 51), que não fazem qualquer reivindicação ou assimilação por uma originalidade pura. Assim, conforme Bhabha (2007) e Tagata (2007) não se trata de um espaço de negação, baseado em binarismos "isso 'ou' aquilo", mas de negociação do "e" que permite a simultaneidade da diferença e da semelhança, da arbitrariedade e do hibridismo por natureza.

${ }^{50}$ Cumpre enfatizar que as autoras se detêm em discutir sobre o fenômeno do "semilinguismo" nas línguas orais, embora a $\operatorname{Prof}^{a} \operatorname{Dr}^{\mathrm{a}}$ Marilyn Martin-Jones tenha autorizado a apropriação dessa leitura para o contexto das línguas de sinais caseiras em suas contribuições como membro da banca de qualificação da dissertação de mestrado de Kumada (2012).

${ }^{51}$ Martin-Jones e Romaine (1986) destacam que a discussão sobre as competências linguísticas do sujeito visto como semilíngue não se restringia a desautorizá-lo sob argumentos de ordem linguística, assim como de ordem cognitiva.

52 " "[...] a crença de que existe tal coisa ideal, um monolíngue completamente competente ou um falante bilíngue que tem uma versão total ou completa da língua.” (MARTIN-JONES; ROMAINE, 1986, p. 32, tradução nossa).
} 
emprestaremos os esquemas propostos por essa autora para guiar essa lógica bilíngue quantitativa representados na Figura 3.1.

Figura 3.1 - Esquema representativo da noção de bilinguismo idealizado

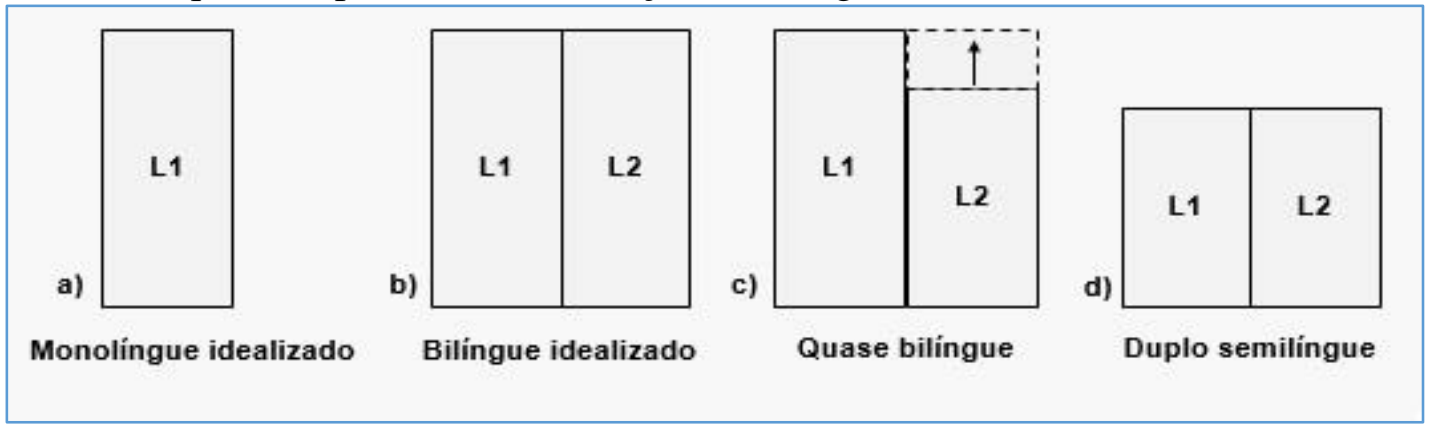

Fonte: Adaptado de Skutnabb-Kangas (1981)

A visão de competência linguística projetada nesse esquema parte do pressuposto de que haja um comando linguístico completo ao qual o monolíngue idealizado seria alocado no container $^{53}$ (a). Por sua vez, no container (b), teríamos um bilíngue idealizado com dois sistemas linguísticos, sendo cada um idêntico ao sistema completo de um monolíngue ideal, ou seja, com habilidades iguais em todas as funções linguísticas. Ao passo que o container (c) representaria um sujeito que possui competência linguística completa na L1 e um alto domínio na L2, apesar de ainda não ser equiparado a um monolíngue da L2 em questão. Entretanto, como já é um monolíngue completo na L1, ele não pode ser visto como um semilíngue. Além disso, apresenta grande potencial para chegar a ser um bilíngue completo. Por fim, dentro dessa lógica, à pessoa que não possui a competência linguística de um monolíngue ideal, seja na L1 ou na L2, como pressupõe o esquema do container (d), estaria reservado o rótulo de "semilíngue" ou "duplo semilíngue".

Para Skutnabb-Kangas (1981) e outros autores como Martin-Jones e Romaine (1986) e Maher (2007) essa concepção quantitativa de bilinguismo acarreta vários problemas. SkutnabbKangas (1981) descreve que essa visão parte de um entendimento estático e rígido das habilidades linguísticas humanas e do próprio conceito de língua como pronta e não como permanentemente em construção.

Crítica semelhante é tecida por Maher (2007) e Martin-Jones e Romaine (1986) ao observarem que quando a competência linguística é inserida em container passa a impressão ser um recipiente, o qual poderia estar "parcialmente cheio" ou "cheio". Maher (2007, p. 77) analisa que sob essas definições, as competências aparecem "[...] aprisionadas em casulos,

\footnotetext{
${ }^{53}$ No trabalho original, Skutnabb-Kangas (1981) não se refere ao seu esquema como container, emprestamos esse termo de Martin-Jones e Romaine (1986, p. 32) que também se apoiam no estudo de Skutnabb-Kangas (1981).
} 
como se pudessem ser fixadas de forma inequívoca e congeladas no tempo", desconsiderando que a língua não é uma “entidade pronta” e que o sujeito bilíngue não, simplesmente, justapõe uma língua à outra.

A língua como um constructo sócio-histórico não pode ser concebida como estática, do contrário ainda estaríamos usando "vossa mercê" em nosso vocabulário e não teríamos incorporado, recentemente, verbos como "deletar", "clicar" ou "tuitar" ${ }^{54 " . ~ A s s i m, ~ a o ~ s e ~ b u s c a r ~}$ uma proficiência completa de seus falantes, esquece-se de que nenhuma língua está pronta ou acabada, mas em constante movimento e sob processos contínuos de (re)construção. Logo, inspiradas em Skutnabb-Kangas (1981), cabe questionar: "Se não podemos mensurar o que seria a totalidade de língua, como exigir do sujeito um bilinguismo completo?”.

Nessa ótica, é oportuno acompanhar Maher (2007) e abandonar idealizações do conceito de língua e de bilinguismo, inclusive no que se refere à busca por um bilinguismo sem mesclas, onde cada língua se aprisiona em um "recipiente" distinto, pois para essa autora cabe reiterar a permeabilidade das línguas que habitam o universo do sujeito bilíngue. Para isso, convém, como sugerem Cox e Assis-Peterson (2007, p. 42), pensar a língua como líquida e não como sólida e, assim, imaginá-la em movimento, vazando uma na outra “[...] como rios que correm e se misturam indistintamente com outros rios." Sob essa vertente de conceituação da língua e com a qual nos alinhamos, as "contaminações" de uma língua na outra constituem um fato natural e recorrente nas práticas comunicativas do sujeito bilíngue. Para Maher (2007, p. 74, grifo do autor):

O funcionamento discursivo do sujeito bilíngue prevê a utilização de mudança de código (code-switching) e empréstimos linguísticos (borrowings) em sua gramática. Um "bom" bilíngue transita de uma língua para outra justamente porque, diferente do monolíngue, tem competência para tanto. [...] Esses procedimentos são, para o bilíngue, recursos comunicativos poderosos dos quais ele lança mão com frequência, para, pragmaticamente, atribuir sentidos vários aos seus enunciados: para expressar afetividade, relação de poder, mudança de tópico, identidade social/étnica etc. Não se trata, portanto, de um déficit, mas de um recurso discursivo sofisticado com que somente os bilíngues podem contar. E é por isso que eles geralmente se sentem mais à vontade na companhia de outros bilíngues: na interação com monolíngues, não podem lançar mão de todas as habilidades comunicativas que têm à sua disposição.

\footnotetext{
${ }^{54}$ Utilizado para traduzir o verbo em inglês to tweet, referente à ação de postar mensagens no microblog Twitter. Para uma discussão mais aprofundada sobre o aportuguesamento dos verbos "clicar" e "deletar", sugerimos a leitura de Cox e Assis-Peterson (2007) e Assis-Peterson (2008) que propõe refletir sobre aspectos de transculturalidade e transglossia em sociedades contemporâneas.
} 
Trata-se, portanto de aceitar que o contexto bilíngue é genuinamente um espaço de hibridismo, no qual se admite misturas, interferências, empréstimos, mudanças de código sem que isso descaracterize as habilidades e competências linguísticas do sujeito bilíngue. Importa destacar o entendimento de hibridismo como uma crítica ao purismo e como origem de todo fenômeno cultural e linguístico (BHABHA, 2007; MENEZES DE SOUZA, 2010).

E se a língua é sempre, naturalmente, situada nesse espaço do hibridismo, é oportuno pensar em novos conceitos que expliquem apropriadamente o bilinguismo. Para Maher (2007, p. 79), somente um conceito genérico seria capaz de abranger sua complexidade e para isso, talvez seja pertinente concebê-lo simplesmente como "[...] a capacidade de fazer uso de mais de uma língua.” Avançando nesse raciocínio, César e Cavalcanti (2007) discutem ainda as condições das variedades linguísticas, muitas vezes invisibilizadas por não serem reconhecidas nessas discussões. Uma maneira de atender línguas e variedades sem pressupor sobreposições de valores de uma sobre a outra seria acolhê-las todas sob o conceito de multilinguismo, isto favoreceria a aceitação das inúmeras combinações e hibridismos gerados na constituição linguística moderna, das quais, como salientam as autoras, nem os grupos minoritários/minoritarizados como os povos indígenas nem as comunidades surdas escapam.

Essa proposta se coaduna ao artigo $5^{\circ}$ da Declaração Universal dos Direitos Linguísticos, de 8 de junho de 1996, em que consta a seguinte redação:

Artigo $5^{\circ}$ Esta Declaração baseia-se no princípio de que os direitos de todas
as comunidades linguísticas são iguais e independentes da consideração
jurídica ou política das línguas oficiais, regionais ou minoritárias. O uso de
denominações tais como língua regional ou minoritária não é adotado neste
contexto porque, embora em algum caso, o reconhecimento como língua
minoritária ou regional possa facilitar o exercício de certos direitos, é
frequente o uso dos determinativos para restringir os direitos de uma
comunidade linguística. (DECLARAÇÃO UNIVERSAL DOS DIREITOS
LINGUÍSTICOS 2003, p. 27).

Fortalecendo o conceito de multilinguismo, cabe resgatar o que Maher (2007) retratou a respeito da dificuldade de se definir assertivamente um número fechado para as línguas existentes no mundo, com estimativas que variam entre 3 mil a 10 mil línguas. Essa indecisão, conforme a autora, decorre justamente do desafio que pesquisadores e responsáveis por tais censos enfrentam em estabelecer critérios para separar o que seja língua daquilo que seria uma variedade linguística.

A propósito de variedades linguísticas em Libras, é possível conferir sua existência no estudo de Silva e Kumada (2013). As autoras realizaram um levantamento dessas variedades 
da Libras que advém, tal como nas línguas orais (BAGNO, 1999; CAVALCANTI, 1999) de condições sociais, geográficas, faixa etária, nível de escolaridade etc. Assim, como Silva e Kumada (2013), Gesser (2006) analisa que essas variedades em Libras também são inscritas em relações assimétricas de poder, em que se estabelece um maior ou menor prestígio. Nessa escala de prestígio, algumas variedades regionais, as línguas de sinais caseiras, a Libras praticada pelo ouvinte e o português sinalizado ${ }^{55}$ tendem a ser as mais estigmatizadas, muitas vezes desautorizadas enquanto língua pelos profissionais e familiares ouvintes, bem como pelos próprios surdos, como é o caso das línguas de sinais caseiras que foram mencionadas como as que mais sofrem discriminação e, por extensão, os seus falantes.

Desse modo, para abrigar a pluralidade cultural e linguística, concordamos com César e Cavalcanti (2007, p. 62, grifo dos autores) que o termo multilinguismo pode, provisoriamente, suprimir “[...] as dicotomias língua e variedade, língua e norma, língua e dialeto [...]”, elevando todas ao mesmo status de língua, inclusive, como sugere Cavalcanti (2011), aquelas que ainda não foram dicionarizadas ou descritas gramaticalmente (e aqui gostaríamos de inscrever as variedades desprestigiadas da Libras, especialmente, as línguas de sinais caseiras).

Seguir por esse caminho torna mais fácil a compreensão de que surdos são sujeitos bi/multilíngues ao invés de semilíngues e que, em síntese, a língua não é estável, não é sólida, não está pronta, não é neutra, não é pura e, por último, não é homogênea. Em nossa visão, a noção ampliada de língua e bi/multilinguismo aqui compartilhada é essencial para se construir um novo olhar sobre o universo linguístico do surdo e da surdez, domínios que não podem ser negligenciados durante os processos seletivos que lidam com o ingresso de candidatos surdos em cursos (que devem ser bilíngues) voltados à formação de professores de Libras.

Como pode ser vislumbrado, a interpretação da surdez como diferença conduz a uma crítica mais refinada sobre as discussões linguísticas deflagradas nesse contexto para, inclusive compreender e organizar, de forma mais eficiente, o trabalho do ensino e da avaliação das línguas envolvidas, incluindo o português como L2, tal como a seção a seguir abordará.

\subsubsection{Considerações sobre o contexto de ensino do português como L2 para surdos}

O acesso dos surdos a cursos de educação superior depende do processo seletivo, geralmente, determinado por uma avaliação que, com frequência, recorre à modalidade escrita

\footnotetext{
${ }^{55}$ Diz respeito à prática de realizar sinais da Libras sob a estrutura sintática da Língua Portuguesa, desrespeitando a sintaxe própria da Libras e perdendo vários recursos gramaticais da Libras como o uso de classificadores e as construções espaciais essenciais para as narrativas.
} 
da Língua Portuguesa. Entretanto, como visto anteriormente, a educação bilíngue de surdos tende a se pautar sobre modelos subtrativos de ensino de línguas, os quais inibem o desenvolvimento da criança na L1, no caso a Libras, com o intuito de "forçá-la" a prosperar na Língua Portuguesa. Essa estratégia acaba repercutindo em insucesso escolar, seja, no avanço de domínio da L1 ou da L2, e o cenário não parece mudar, tendo em vista que pouco se investe na formação e contratação de professores de Libras, bem como em métodos e estratégias de ensino dessa língua minoritária/minoritarizada, na mesma medida em que pouco avançamos concernente ao ensino da Língua Portuguesa. Torna-se, como Favorito (2006) declarou, um círculo vicioso para o fracasso da educação de surdos, com o qual temos demonstrado dificuldade de nos desvencilharmos.

Para Skliar (2016), a mera admissão do sujeito surdo como bilíngue não tem garantido a reconversão do problema, é preciso tomar clareza dos processos e das relações de poder que permeiam esse contexto bilíngue escolar pelo qual os surdos passaram e ainda passam. Quando a Libras e a Língua Portuguesa estão em questão, como já discutimos, há uma significativa diferença entre o prestígio que cada uma assume no sistema educacional, principalmente, nas representações de alunos e educadores. Mas, o que deve ser destacado, conforme esse autor, é que a Libras não é a língua dos professores e profissionais ouvintes que atuam nessa(s) escola(s), e aqui incluímos as escolas bilíngues, nas quais o corpo de funcionários é, geralmente, composto por uma maioria ouvinte (SKLIAR, 2016).

No entanto, enquanto permanecermos arraigados no "círculo vicioso" do fracasso escolar essa realidade não irá se transformar, pois, conforme Skliar (2016), nos dias de hoje ainda testemunhamos uma mínima parcela de estudantes surdos acessando a educação superior. Para esse autor, três explicações têm sido, recorrentemente, projetadas quando se busca responsáveis pela ineficácia da educação de surdos. A primeira culpabiliza os próprios surdos, inferindo aspectos biológicos, linguísticos e cognitivos que os restringem. Uma segunda explicação está centrada nos professores ouvintes e uma terceira nos métodos de ensino, que deveriam ser mais sistematizados, rigorosos e impiedosos com os surdos. Nota-se que, dificilmente, são consideradas as responsabilidades da escola enquanto instituição, das políticas educacionais e do Estado.

Para Skliar (2016) as raízes do fracasso educacional dos surdos são, na verdade, resultado de um conjunto de "subfracassos", pois:

O que fracassou na educação dos surdos foram as representações ouvintistas acerca do que é o sujeito surdo, quais são os seus direitos linguísticos e de 
cidadania, quais são as teorias de aprendizagem que refletem condições cognitivas dos surdos, quais as epistemologias do professor ouvinte na sua aproximação com os alunos surdos, quais são os mecanismos de participação das comunidades surdas no processo educativo, etc. (SKLIAR, 2016, p. 18).

Assim, observa-se uma miríade de fatores que desencadeou o quadro de insucesso, e, em concordância com Sanchez (2015), não pode ser analisada isoladamente ou também cairemos na ingenuidade de acreditar que apenas o ensino e a aprendizagem da escrita para surdos apresentam problemas. De acordo com esse autor, é preciso ter cautela em nosso juízo, pois uma grande parte dos ouvintes também não é capaz de fazer um bom uso da língua escrita e lhe é garantida, ao menos, a instrução da língua materna.

Isso posto, para analisar a seleção de candidatos para ingresso na educação superior, não podemos desconsiderar as condições de aprendizagem da Língua Portuguesa vivenciada pelos alunos surdos em seu processo educacional, tampouco aplicar-lhes os mesmos conteúdos, estratégias e expectativas da avaliação realizada junto aos ouvintes que são usuários do português como L1. A respeito desse posicionamento, explicaremos os motivos.

Primeiramente, o ensino e a avaliação da Língua Portuguesa, conforme apontado por Skliar (2016) e Sanchez (2015), não podem perder de vista que a educação bilíngue dos surdos está além da oferta de duas línguas em concomitância. Por essa razão, o acesso desses estudantes ao ensino da modalidade escrita da Língua Portuguesa como L2 está assegurado pelo Decreto $\mathrm{n}^{\circ}$ 5.626/05 (BRASIL, 2005), estabelecendo que as instituições federais de ensino devem promover capacitações e profissionais específicos para exercerem tal função. $\mathrm{O}$ reconhecimento dessa condição também é previsto na Meta 4 do PNE/14 na qual se estabelece como estratégia:

[...] garantir a oferta de educação bilíngue, em Língua Brasileira de Sinais LIBRAS como primeira língua e na modalidade escrita da Língua Portuguesa como segunda língua, aos (às) alunos (as) surdos e com deficiência auditiva de 0 (zero) a 17 (dezessete) anos, em escolas e classes bilíngues e em escolas inclusivas [...] (BRASIL, 2014, p. 3, grifo nosso).

No entanto, cumpre ressaltar que nem todos os municípios possuem escolas bilíngues para surdos, e que, majoritariamente, esse grupo de alunos frequenta a classe comum (CAMPOS, 2013; LODI, 2013), onde, como se sabe, habitualmente vigora o ensino da Língua Portuguesa como L1, sobretudo sob métodos fônicos de alfabetização que partem da correlação entre grafema e fonema. 
É possível ilustrar essa afirmação com o trabalho de Kumada e Silva (2016), no qual as autoras analisaram três livros didáticos de ensino de Língua Portuguesa pertencentes ao Projeto Pitanguá $^{56}$, materiais que integram uma proposta bilíngue para surdos e compõem a distribuição livre feita pelo Programa Nacional do Livro Didático do MEC às escolas públicas. Os referidos livros didáticos acompanham um encarte com CD-ROM onde consta o texto escrito do livro e a alternativa para, clicando sobre esse texto, obter a tradução para a Libras. Apesar da importância dessa iniciativa, conforme verificado pelos autores, o material reproduzia estratégias de ensino de Língua Portuguesa como L1, simplesmente traduzindo o conteúdo para a língua de sinais. Assim, por exemplo, o livro didático continha enunciados onde se solicitava ao aluno surdo, de forma escrita e em Libras, para ler as palavras em voz alta e comparar quais sons se repetiam nelas. Evidentemente, o material se propõe bilíngue, mas faz uma leitura rasa e superficial das implicações do significado de bilinguismo para surdos.

Sanchez (2015) entende que a primeira decisão no caminho para o êxito do ensino da escrita para surdos seria aceitar que o seu processo de alfabetização não transcorre sob as mesmas características dos alunos ouvintes. Nessa mesma linha de raciocínio, muito se tem discutido sobre a necessidade de os professores utilizarem recursos e estratégias metodológicas de ensino que potencializam a aprendizagem dos estudantes surdos (LACERDA; SANTOS; CAETANO, 2013). Neste sentido, os educadores têm sido orientados a lançarem mão, por exemplo, de "[...] filmes, textos de literatura, manchetes de jornais, programas televisivos [...]" (LACERDA; SANTOS; CAETANO, 2013, p. 185) que auxiliam os alunos ouvintes, mas são imprescindíveis ao aluno surdo. Com base nessa importância de elementos visuais, Lacerda, Santos e Caetano (2013) defendem uma pedagogia visual para surdos, ou seja, na valorização da visualidade na prática educacional.

Para o enfoque em uma pedagogia visual, a Libras e o texto escrito não são o bastante, sendo necessário explorar elementos imagéticos como "[...] uma maquete, um desenho, um mapa, um gráfico, uma fotografia, um vídeo, um pequeno trecho de filme [...]” (LACERDA; SANTOS; CAETANO, 2013, p. 188). As autoras asseveram que, apesar dos benefícios, ainda são poucas as produções sobre a relevância da visualidade no contexto da educação de surdos,

\footnotetext{
${ }^{56}$ A escolha da análise desses livros didáticos foi realizada a partir de uma visita desta pesquisadora a uma escola bilíngue para surdos que fazia uso desse material e os doou gentilmente para análise. Além disso, cumpre salientar que a divulgação deste deriva de meu trabalho final na disciplina de mestrado intitulada Ensino-aprendizagem de português como segunda língua e língua estrangeira, cursada no Instituto de Estudos da Linguagem da Unicamp. Portanto, os livros são materiais de circulação no ensino de português para surdos e a análise foi feita à luz de leituras sobre como deveria ser concebido o ensino de português como L2.
} 
mas que essa deveria perpassar a elaboração de currículos e estratégias didáticas (LACERDA; SANTOS; CAETANO, 2013).

Na mesma vertente, Reily (2003) utiliza o conceito de "letramento visual" para surdos com o intento de destacar o uso da imagem nesse contexto educacional bilíngue. Para a autora, as escolas e os livros didáticos ainda utilizam a imagem como recurso meramente decorativo e os professores pouco exploram o letramento visual, conceito que abrange desde a leitura de imagens do entorno até livros ilustrados, páginas de livros, símbolos e figuras. Esse contato com a imagem inclui, conforme descreve Reily (2003, p. 175), "tocar as figuras, apontar, mostrar detalhes importantes, seguir os movimentos, pintar, imitar os gestos dos personagens [...]”, enfim, diversas atividades que podem colaborar para o processo de alfabetização e letramento de aprendizes surdos.

Esses conhecimentos, segundo Goularte (2014), já têm sido incorporados nos processos seletivos da UFSM, a qual observou que, inicialmente, as traduções das provas de vestibulares para os surdos se atentavam apenas ao aspecto linguístico. Entretanto, com o tempo, ao se reconhecer as questões culturais do sujeito surdo se denotou a necessidade de utilização de recursos visuais que favoreciam não apenas o processo de aprendizagem, como também a avaliação desses sujeitos (GOULARTE, 2014).

Outra estratégia que tem sido focalizada por vários estudos (QUADROS; SCHMIEDT, 2006; SÃO PAULO, 2008; SILVA; KUMADA; NOGUEIRA, 2012) no trabalho de Língua Portuguesa com alunos surdos se embasa em contar histórias, ou seja, na exploração do gênero discursivo narrativo.

Quadros e Schmiedt (2006) enfatizam que o ensino da Língua Portuguesa como L2 deve partir da L1 do aluno, ou seja, da Libras. Portanto, durante a narrativa de histórias, é possível explorar a literatura primeiro em língua de sinais, despertando o interesse, introduzindo o enredo, organizando o funcionamento do gênero textual e, posteriormente, realizando a leitura do texto escrito, trabalhando contrastivamente com os aspectos linguísticos da Libras e da Língua Portuguesa.

Cabe enfatizar o que consta no documento de orientações para ensino de Língua Portuguesa para surdos de São Paulo (SÃO PAULO, 2008), quando afirma que aos alunos surdos deve ser garantida variedade de contato com textos ricos e diversificados. Julgamos pertinente trazer essa passagem, pois, muitas vezes, a concepção dos professores sobre as potencialidades dos surdos interfere na admissão de textos empobrecidos, pois esses acreditam que o aluno surdo tem dificuldade e não é capaz de ler textos mais complexos. Contudo, sem acesso a textos ricos e diversificados, consequentemente, irão se desmotivar e desinteressar pela 
leitura e escrita (SÃO PAULO, 2008). Além disso, é preciso atentar-se para o fato de que esse posicionamento assumido por alguns professores pode ir além da educação básica e chegar à organização das provas que controlam o ingresso dos candidatos surdos à educação superior, sob o risco de distorcer o que estamos concebendo como adequação do português para surdos para entendê-lo como uma pauperização dos textos e conteúdos.

Ademais, sendo os surdos aprendizes de português como L2, é preciso que os professores e os responsáveis pelos sistemas de avaliação considerem as influências que serão naturalmente deflagradas nesse processo, algo comum a todos os aprendizes de uma L2 ou língua estrangeira ${ }^{57}$, ou seja, níveis de sofisticação apresentados durante a aquisição linguística com características específicas do percurso que o sujeito trilha ao partir da L1 para a L2 (QUADROS; SCHMIEDT, 2006).

Quadros e Schmiedt (2006) salientam que a escrita de um aprendiz de português como segunda língua não ocorre de forma desorganizada, há hipóteses e regras que são comuns e ilustram esse processo de construção de um sistema linguístico que embora já não seja mais a L1 do aluno, ainda não corresponde à L2. Nesse percurso, haverá estágios com maior ou menor influência da sintaxe, da flexão verbal e nominal, da ocorrência ou uso inadequado de verbos de ligação, da ausência ou inadequação de preposições, artigos e conjunções, entre outros elementos que apresentam considerável distinção no que se refere à organização da gramática da Libras e do português.

Tendo em vista todas as condições diferenciadas de aprendizado envolvidas nesse processo de aquisição da escrita pelos alunos surdos, a legislação prevê o dever, por parte das instituições de ensino, de "adotar mecanismos de avaliação coerentes com aprendizado de segunda língua, na correção das provas escritas, valorizando o aspecto semântico e reconhecendo a singularidade linguística manifestada no aspecto formal da Língua Portuguesa" (BRASIL, 2005, p. 29).

Na sequência, o referido decreto ainda estabelece que é possível desenvolver e adotar outras formas de avaliação para conhecimentos expressos em Libras, desde que registrados em vídeos ou outros meios eletrônicos e tecnológicos (BRASIL, 2005). Evidentemente, para que

\footnotetext{
${ }^{57}$ Esclarecemos que estamos entendendo por segunda língua ou L2 “[...] o termo utilizado para referir-se ao ensino da língua estrangeira no país onde ela é falada como língua materna de minorias e/ou oficial/nacional [...]" (VIANA, 1997, p. 29), e como língua estrangeira (também conhecida como LE) “[...] o ensino da língua estrangeira em países onde essa língua não é materna/oficial ou nacional.” (VIANA, 1997, p. 29). Por outro lado, sabemos da existência de alguns autores, tal como Nicolaides e Tilio (2013, p. 285), que optam pelo termo "língua adicional", pois o conceito de adicional se aplica a qualquer língua aprendida, além da L1, seja ela estrangeira ou não. Para os autores, essa é uma alternativa de se evitar conotações indesejáveis possivelmente atribuídas às línguas estrangeiras como línguas exóticas, inferiores, superiores ou substitutivas da L1. Ainda assim, mantemos o uso do termo "segunda língua", expressão que é comumente utilizada na maioria dos estudos linguísticos.
} 
isso ocorra, ou seja, para que haja um ensino e uma avaliação que considere os aspectos semânticos de interferência da Libras sobre a escrita da Língua Portuguesa, bem como as singularidades sintáticas e morfológicas das línguas envolvidas, o professor precisará ter conhecimentos sobre essas duas línguas para desenvolver atividades epilinguísticas e metalinguísticas dentro de uma abordagem contrastiva. Em suma, somente conhecendo ambas as línguas o profissional será capaz de compreender e intervir de forma adequada nas hipóteses construídas pelo aluno, estabelecendo relações de aproximação e distanciamento entre as regras de funcionamento da Libras (L1 do aluno) e da Língua Portuguesa.

Para tanto, o Decreto $\mathrm{n}^{\mathrm{o}}$ 5.626/05 (BRASIL, 2005) determina que o perfil profissional destinado ao ensino da Língua Portuguesa para surdos deve ser efetuado por meio da graduação em curso de Letras com habilitação em Libras/Língua Portuguesa como segunda língua para surdos, além de se incluir o ensino de português como L2 para surdos como disciplina curricular nos cursos de formação de professores para a educação infantil, anos iniciais do ensino fundamental, médio e superior, bem como para as graduações em Letras com habilitação em Língua Portuguesa. Apesar dessa orientação legal, Soares (2013) indica que essas medidas ainda não foram satisfatoriamente contempladas pelas IES brasileiras. Em sua pesquisa, o autor afirma que, além da disciplina de Libras e dos cursos de graduação que habilitam para docência da Libras, são raras as iniciativas para se formar o professor de português para o atendimento da população escolar surda, seja concernente às disciplinas ou aos cursos de graduação aludidos pelo Decreto $n^{0}$ 5.626/05 (BRASIL, 2005).

Essa realidade reforça a tese de que, mais de uma década após o referido decreto, continuamos reproduzindo "velhas práticas" de um bilinguismo subtrativo e assimilacionista que desconsidera e desconhece as condições necessárias para a garantia de formação bilíngue do sujeito surdo e, portanto, corroboram o fracasso desses sujeitos na aquisição da leitura e da escrita. Essas são considerações que devem ser ponderadas durante a avaliação das competências linguísticas dos candidatos surdos nos processos seletivos pautados em avaliações escritas, pois, diante do panorama elucubrado, pressupomos que seria incoerente culpabilizar exclusivamente esses indivíduos por não apresentarem um exímio domínio da Língua Portuguesa.

Em face disso, tendo olhado para o ensino de português para surdos, cumpre também propor reflexões no que tange ao contexto do ensino da Libras, uma vez que esta tese se pauta, inclusive, pelo nosso interesse na formação de professores desse sistema linguístico. 


\subsubsection{Considerações sobre o contexto de ensino de Libras}

Convém destacar que, dentre os processos seletivos que foram aqui investigados, deparamo-nos com alguns em que o domínio da Libras consistia em pré-requisito para o ingresso, sendo, portanto, avaliado durante o vestibular, tal como habitualmente se observa em universidades que exigem os chamados testes de habilidades específicas para o acesso a cursos como, por exemplo, educação física, arquitetura, música, dança, entre outros. Vale pontuar que em processos seletivos envolvendo alguns cursos de Letras com habilitação, por exemplo, em inglês ou em espanhol também é comum examinar se o candidato apresenta um domínio básico da língua escolhida. Nessa direção, consideramos pertinente contextualizar brevemente como tem ocorrido o ensino da Libras no país.

A regulamentação da Libras por intermédio do Decreto $n^{\circ}$ 5.626/05 (BRASIL, 2005), estabeleceu a obrigatoriedade de sua disciplina nos currículos de cursos de educação superior voltados para as licenciaturas e Fonoaudiologia, mas essa formação geralmente ministrada em um semestre é deveras insuficiente e, como já foi discutido, há ainda poucos cursos de graduação para formação de professores de Libras, resultando em um escasso número de profissionais capacitados para suprir a demanda de ensino da Libras para crianças surdas (LACERDA; ALBRES; DRAGO, 2013). De acordo com Quadros (2006a, p. 152), mesmo para a docência da Libras nos cursos de graduação "[...] deparou-se com a quase inexistência deste profissional devidamente qualificado."

Nessa direção, Gesser (2012) relata que, muitas vezes, o ensino da Libras tem sido ministrado por pessoas surdas (ou ouvintes) sem formação pedagógica necessária, sob a simples exigência de domínio (ou conhecimento) da Libras. A autora afirma que, com efeito, "[...] conhecer uma língua para usar não é o mesmo que saber sobre uma língua para teorizar. Mas, para aqueles que atuam no âmbito pedagógico, ter noções linguísticas sobre o funcionamento das línguas é premissa básica da formação profissional.” (GESSER, 2012, p. 82).

No entanto, é bastante comum nos defrontarmos com argumentos de pouco embasamento teórico em defesa do ensino da Libras baseado, simplesmente, no domínio de seu uso. Essa afirmação pode ser evidenciada na pesquisa de mestrado apresentada por Rebouças (2009), na qual os participantes entrevistados bem como a própria pesquisadora surda defendem uma pretensa legitimidade natural dos surdos para a docência de Libras, autorizados para o seu ensino, inclusive em situações em que não haja diploma para tal atribuição.

Em concordância com Gesser (2012), contrapomo-nos a argumentos desse gênero, por admitir que ser surdo não é condição suficiente para assegurar sua competência didática no 
ensino da Libras. Posicionamento compartilhado por Albres (2014), para quem as competências linguísticas e comunicativas de um professor de língua devem ser muito mais amplas do que a de um falante. Na visão dessa autora, para ensinar uma língua, seja oral ou de sinais, não basta ser fluente, é preciso compreender as teorias e metodologias de ensino de línguas.

No rastro dessa discussão, como pesquisadora da área de ensino de Libras para alunos ouvintes, Gesser $(2006,2012)$ tem observado que, diante da falta de formação linguística, o docente surdo tende a se orientar pelas próprias experiências tidas enquanto aluno, geralmente baseadas em estratégias mecanicistas, intrinsecamente arraigadas a uma "[...] abordagem estrutural, em que a apresentação e prática da língua-alvo se reduzem à repetição e treino de vocabulário por campo semântico [...]" (GESSER, 2012, p. 118). São, geralmente, listas de palavras/sinais apresentadas, de forma descontextualizada das situações de uso, para os alunos repetirem e memorizarem, que em condições mais promissoras são organizadas em pequenas frases $^{58}$.

Assim, no campo do ensino da Libras como L2, a autora já denota uma grande dificuldade na aprendizagem da Libras a partir dessas estratégias didáticas, e a justificativa quase sempre aceita para a ineficácia desse ensino é a de que "só é possível aprender Libras no contato com outros surdos" (GESSER, 2012, p. 75, grifo do autor). Muitos professores e alunos aderem a esse discurso para explicar que o curso de Libras não garantirá a fluência na língua, mas na interpretação da autora, esse é um equívoco, sem nenhum fundamento científico, pois se o aprendizado de uma língua estrangeira dependesse exclusivamente desse convívio, as pessoas somente aprenderiam inglês ou francês se viajassem para outro país, ou se estivessem diante de um professor "nativo". Evidentemente, o convívio com os surdos fluentes em Libras favorece o aprendizado dessa língua, mas, acreditamos, que essa prática não pode ser concebida como o único caminho, do contrário as escolas de línguas estrangeiras deveriam contratar, apenas, professores nativos nas respectivas línguas ensinadas.

Crenças errôneas sobre o ensino da Libras como L1 ou como L2 remetem aos desafios identificados nesse contexto, tanto na falta de investimento para formação desses profissionais como na carência de discussões teóricas que sustentem essa prática, permitindo se avançar nesse

\footnotetext{
${ }^{58}$ A experiência desta pesquisadora como professora de Atendimento Educacional Especializado indica que o mesmo modelo mecanicista tem sido aplicado na prática de ensino da Libras como L1 para surdos, pois durante visitas feitas às escolas era comum encontrar listas de sinais sendo apresentadas em forma de recortes e coladas no caderno. Assim, os sinais da Libras eram trabalhados de forma estática para serem pintadas e decoradas de modo descontextualizado. Em certa ocasião, o nível de falta de domínio dos "professores" de Libras era tanto que foi testemunhado o trabalho com um alfabeto manual da língua de sinais de outro país, se passando pelo da Libras, pois fora extraído da internet por um docente sem formação que o reproduzia indistintamente para a criança surda e para os demais membros da comunidade escolar ouvinte.
} 
campo tal como ocorre nos métodos de ensino de línguas de prestígio. Para isso, há várias questões que precisam ser ponderadas, algumas delas já expostas e outras que gostaríamos de pontuar.

Acreditamos na necessidade do reconhecimento da Libras como disciplina curricular não apenas nos cursos de graduação como tem sido vislumbrada (BRASIL, 2002, 2005), mas no programa de formação dos alunos surdos, permitindo-lhes progredirem na L1 para, consequentemente, adquirirem mais ferramentas linguísticas e cognitivas para obtenção do sucesso na L2, tal como ocorre com os alunos ouvintes que têm na escola as oportunidades de se desenvolverem na sua L1. Outro tópico que julgamos importante é o maior investimento na formação e na contratação de professores qualificados para ministrarem o ensino da Libras, o que corrobora a pertinência de nossa proposta ao analisar os cursos universitários existentes nesse âmbito.

Compreendemos a relevância de uma formação didática para que o professor de Libras tenha clareza de que o ato de planejar o ensino de línguas não se restringe a uma técnica, assim como inclui uma atividade intencional e ideologicamente construída, pois em concordância com Luckesi (2008, p. 102), autor que discute sobre o planejamento e avaliação na escola:

O ser humano age em função de construir resultados. Para tanto, pode agir aleatoriamente ou de modo planejado. Agir aleatoriamente significa "ir fazendo as coisas", sem ter clareza de [a]onde se quer chegar; agir de modo planejado significa estabelecer fins e construí-los através de uma ação intencional. Os fins, sem a ação construtiva, adquirem a característica de fantasias inócuas; a ação aleatória, sem fins definidos, desemboca no ativismo.

Além disso, quando inseridos no contexto escolar, os professores, segundo Prieto (2006, p. 58):

[...] devem ser capazes de analisar os domínios de conhecimentos atuais dos alunos, as diferentes necessidades demandas nos seus processos de aprendizagem, bem como, com base pelo menos nessas duas referências, elaborar atividades, criar ou adaptar materiais, além de prever formas de avaliar os alunos para que as informações sirvam para retroalimentar seu planejamento e aprimorar o atendimento aos alunos.

Portanto, são inúmeras as demandas do professor que ultrapassam a "legitimidade surda" postulada por Rebouças (2009) e que, em nossa visão, estão inerentes à exigência de uma formação pedagógica e linguística específica capaz de administrar a complexidade da diferença do sujeito surdo. Por essa razão, fortalecemos a pertinência do presente estudo, 
sobretudo para se examinar se essa almejada formação, cuja expectativa é de sintonia com os preceitos da diferença linguística, identitária, cultural e educacional circunscritos nos Estudos Surdos, já demonstram consciência dessa responsabilidade durante a organização de seus processos seletivos.

Destarte, explicitado o local teórico de onde narramos, ou seja, os autores e os principais conceitos trabalhados durante a discussão dos resultados, na sequência, faz-se mister apresentar o referencial metodológico com o qual nos fundamentamos e os procedimentos metodológicos utilizados durante o registro e a análise dos dados. 


\section{METODOLOGIA}

Este capítulo tem por objetivo apresentar os conceitos teórico-metodológicos pelos quais a presente tese se norteou. Alinhados aos pressupostos da abordagem qualitativa (DENZIN; LINCOLN, 2006; SEVERINO, 2007; PIRES, A. 2008), servimo-nos, especificamente, dos conhecimentos e das contribuições teóricas acumuladas pela literatura sobre a pesquisa documental (BARDIN, 1977; LÜDKE; ANDRÉ, 1986; SEVERINO, 2007; SÁ-SILVA; ALMEIDA; GUINDANI, 2009), discutindo como nos favorecemos de suas vantagens para a construção de nosso percurso metodológico. Na sequência, descrevemos e justificamos a seleção do contexto de pesquisa, bem como os instrumentos empregados nos procedimentos de geração de dados e de interpretação e análise dos dados.

\subsection{A ABORDAGEM QUALITATIVA}

De acordo com Severino (2007), a prática científica dispõe de uma gama diversificada de procedimentos e técnicas para coleta e análise de dados, mas sua escolha não ocorre aleatoriamente. A aplicação desse instrumental deve ser guiada à luz de uma prática metodológica que, por sua vez, seja justificada e sustentada por uma fundamentação epistemológica, pois, nas palavras do autor, “[...] a ciência é sempre o enlace de uma malha teórica com dados empíricos, é sempre uma articulação do lógico com o real, do teórico com o empírico, do ideal com o real.” (SEVERINO, 2007, p. 100).

Nessa premissa, autores como Sá-Silva, Almeida e Guindani (2009) argumentam que o direcionamento da pesquisa deve ser concebido a partir da natureza do objeto, do problema da pesquisa e da corrente teórica pela qual o pesquisador se associa. Portanto, ao considerar a articulação entre o fazer científico e os saberes teórico-metodológicos nos alinhamos aos preceitos da abordagem qualitativa ${ }^{59}$ (LÜDKE; ANDRÉ, 1986; DENZIN; LINCOLN, 2006; SEVERINO, 2007; PIRES, A., 2008), entendendo-a como um campo que abriga diferentes

\footnotetext{
${ }^{59}$ Autores como Severino (2007), Lüdke e André (1986) adotam a o termo "abordagem" qualitativa, enquanto outros estudiosos como Denzin e Lincoln (2006), Deslauriers e Kérisit (2008) e Pires, A. (2008) preferem "pesquisa" qualitativa. Segundo Severino (2007), é de conhecimento geral e consagrado na linguagem de uso acadêmico que ao se dizer "pesquisa qualitativa" não há referência a uma metodologia em particular, mas a um conjunto de metodologias que, eventualmente, pertencem a diferentes referências epistemológicas. Entretanto, exatamente por não se tratar de uma metodologia em particular, o autor julga ser preferível utilizar o termo "abordagem" qualitativa em lugar de "pesquisa" qualitativa. Com base nessa reflexão, em nosso estudo, buscamos utilizar o termo "abordagem" qualitativa, porém para respeitar a nomenclatura adotada por alguns autores, faremos uso de "pesquisa" qualitativa, quando assim constar no trabalho original mencionado.
} 
metodologias $^{60}$ (SEVERINO, 2007) ou como um terreno que “[...] serve como 'lar' para uma ampla variedade de estudiosos." (SCHWANDT, 2006, p. 194).

Segundo Denzin e Lincoln (2006), a pesquisa qualitativa pode ser concebida como transdisciplinar e, às vezes, contradisciplinar ${ }^{61}$, pois não possui uma única face, um único método ou um único paradigma, na verdade, ela se faz emprestar a várias disciplinas, a vários objetos de estudos, a várias escolas e comunidades científicas, o que se harmoniza com aquilo que percorremos no capítulo anterior ao visitarmos diferentes campos de conhecimento. Denzin e Lincoln (2006) descrevem a pesquisa qualitativa como um campo de investigação que perpassa áreas do saber, disciplinas e temas, mas que, consequentemente, torna seu contexto histórico bastante complexo para restringi-la sob uma única definição, uma vez que possui “"[...] histórias independentes e distintas nas áreas da educação, do trabalho social, das comunicações, da psicologia, da história, dos estudos organizacionais, da ciência médica, da antropologia e da sociologia" (DENZIN; LINCOLN 2006, p. 38).

Interpretação idêntica é compartilhada por Schwandt (2006) ao se reportar ao caráter multidisciplinar da investigação qualitativa como um "lar" para uma ampla variedade de estudiosos que, apesar de inseridos em uma base epistemológica comum, podem, muitas vezes, evidenciar desarmonia em seus discursos e definições do que constitui a abordagem qualitativa. $\mathrm{O}$ autor esclarece que a desarmonia relatada pode estar intrínseca ao interesse no qual o pesquisador se serve para desenvolver a pesquisa social ou ainda as diferentes posturas epistemológicas da investigação qualitativa.

Com base no exposto, tendo nos vinculado à abordagem qualitativa, buscamos justificála sob uma conceituação teórica, mas nos deparamos com esse desafio, pois exatamente por atender diferentes contextos, torna-se complexa a tarefa de aprisioná-la em uma definição que não vislumbre a abrangência de sua natureza. Conforme destacado por Pires, A. (2008), um

\footnotetext{
${ }^{60} \mathrm{O}$ autor não especifica a definição do que está considerando como "metodologia", porém, é possível inferir que ele a entenda de modo compatível com o conceito de pesquisa, visto que intitula como Modalidades $e$ Metodologias de Pesquisa Científica a seção em que, primeiramente, explora as abordagens qualitativa e quantitativa e, posteriormente, trata das pesquisas etnográfica, participante, ação, estudo de caso, entre outros (SEVERINO, 2007, p. 117).

${ }^{61}$ Ao citarem as expressões "interdisciplinar", "transdisciplinar" e "contradisciplinar", Denzin e Lincoln (2006) não definem tais conceitos, porém, dado o contexto no qual as expressões são utilizadas para descrever a pesquisa qualitativa como um campo que é "muitas coisas ao mesmo tempo", "miscigenada" e "multiparadigmática" (DENZIN; LINCOLN, 2006, p. 21), partimos da interpretação de que esteja em harmonia com o estudo de Moita Lopes (2006). Para tal autor, que também se alinha à Denzin e Lincoln (2006), a natureza "interdisciplinar/transdisciplinar" diz respeito ao diálogo entre teorias no qual se atravessam várias áreas do saber. Moita Lopes (2006, p. 26) não utiliza o termo "contradisciplinar", mas adota a expressão "indisciplinar" para adjetivar os estudos que transgridem os "[...] limites disciplinares, com verdades únicas, transparentes e imutáveis." Neste sentido, em nossa interpretação, seria possível equiparar os conceitos de "indisciplinar" e "contradisciplinar", compreendendo que ambos fariam menção a um posicionamento "contrário" à noção de "disciplina" ou ao aprisionamento a uma única disciplina do saber.
} 
olhar mais amplo para a história das ciências sociais denuncia o quão desafiador pode ser a busca por uma delimitação ou caracterização do que se denomina abordagem qualitativa.

Ao situarem o contexto da América do Norte, Denzin e Lincoln (2006) descrevem que a pesquisa qualitativa atravessou sete momentos históricos e, em cada um desses momentos, retratou um significado diferente. Apesar disso, sob uma definição genérica poderia se afirmar que "[...] a pesquisa qualitativa é uma atividade situada que localiza o observador no mundo." (DENZIN; LINCOLN, 2006, p. 17).

Apesar da natureza diversificada da abordagem qualitativa, nos interessa compactuar com Pires, A. (2008), para quem a pesquisa qualitativa também pode estar vinculada a "pesquisas puramente documentais" que não são "multimétodos" e não são realizadas no contexto natural dos atores. Sob o ponto de vista desse autor, a tarefa de definir pesquisa qualitativa se trata, na verdade, de identificar o modo menos fechado de designá-la, pois a concepção de abordagem qualitativa é essencialmente abrangente. Assim, concordamos com Pires, A. (2008) sobre a adoção de uma designação genérica e provisoriamente aceitável provisória, pois essa pode não corresponder a realidade de tendências de pesquisas futuras - que parte da caracterização de pesquisa qualitativa a partir de cinco aspectos gerais:

a) por sua flexibilidade de adaptação durante seu desenvolvimento, inclusive no que se refere à construção progressiva do próprio objeto da investigação; b) por sua capacidade de se ocupar de objetos complexos, como as instituições sociais, ou grupos estáveis, ou ainda, de objetos ocultos, furtivos, difíceis de apreender ou perdidos no passado; c) por sua capacidade de englobar dados heterogêneos, ou, como o sugeriram Denzin e Lincoln (1994: 2), de combinar diferentes técnicas de coleta de dados; d) por sua capacidade de descrever em profundidade vários aspectos importantes da vida social concernentemente à cultura e à experiência vivida, justamente devido à sua capacidade de permitir ao pesquisador dar conta (de um modo ou de outro) do ponto de vista do interior, ou de baixo; e) finalmente, por sua abertura para o mundo empírico, a qual se expressa, geralmente, por uma valorização da exploração indutiva do campo de observação, bem como por sua abertura para a descoberta de "fatos inconvenientes" (Weber), ou de "casos negativos". (PIRES, A., 2008, p. 90).

Com base no exposto, sob proveito do caráter interdisciplinar e da flexibilidade da pesquisa qualitativa, e por sua capacidade de investigar aspectos importantes da vida social abordando o fenômeno em diferentes perspectivas, adotamos nesta tese o uso da abordagem qualitativa que, conforme mencionado por Pires, A. (2008), sustenta não só pesquisas multimétodos desenvolvidas em ambientes naturais, bem como permite o trabalho com a pesquisa documental, mesmo que os métodos não sejam tão variados e o cenário em questão 
não seja o contexto natural dos sujeitos. Isso posto, na próxima seção nos deteremos, especificamente, sobre a escolha da pesquisa documental.

\subsection{A PESQUISA DOCUMENTAL E OS DOCUMENTOS COMO UMA VALIOSA FONTE DE INFORMAÇÕES}

Tradicionalmente, o conceito de documento tem forte relação com o texto escrito, pois, conforme Le Goff (2003), o documento como objeto de estudo nasceu entre os historiadores. Para o autor, a memória coletiva da sociedade se forma a partir de dois tipos de materiais: os documentos e os monumentos. Os documentos partiram em um primeiro momento do termo latino documentum derivado de docere que significa "ensinar", mas evoluiu para o significado de prova, especialmente no âmbito jurídico, tendo sido relacionados aos documentos oficiais. Até o século XX, os historiadores, sobretudo positivistas, concebiam documento e texto como sinônimos e atribuíam o mais alto valor para os documentos, chegando a afirmar que a sobrevivência de um fato histórico na memória coletiva dependia do seu registro documental.

No século XXI, o conceito de documento se ampliou, sendo aceito o seu registro “[...] escrito, ilustrado, transmitido pelo som, a imagem ou qualquer outra maneira." (SAMARAN, 1961, p. XII apud LE GOFF, 2003, p. 531). Apesar das categorias de documentos terem se diversificado ao longo dos anos, concordamos com Le Goff (2003) ao vislumbrar que a análise do documento permanece situada em um contexto histórico e político, pois:

O documento não é qualquer coisa que fica por conta do passado, é um produto da sociedade que o fabricou segundo as relações de forças que aí detinham o poder. Só a análise do documento enquanto monumento permite à memória coletiva recuperá-lo e ao historiador usá-lo cientificamente, isto é, com pleno conhecimento de causa. (LE GOFF, 2003, p. 535-536).

Portanto, na leitura do referido autor, o pesquisador deve estar atento diante dos documentos, visto que, de forma subjacente, representam o "[...] esforço das sociedades históricas para impor ao futuro - voluntária ou involuntariamente - determinada imagem de si próprias [...]" (LE GOFF, 2003, p. 538). Conforme esse autor, são poucos os documentos que alcançam o poder de se perpetuar como legado da memória coletiva de uma sociedade; aos documentos investidos por essas características o autor atribui a denominação "monumentos".

Refletir acerca do conceito de documento a partir da ótica de Le Goff (2003) nos interessa, sobremaneira, porque a presente pesquisa de doutorado elegeu como principal produto de análise os editais de processos seletivos para o acesso aos cursos de graduação 
voltados para a formação de professores de Libras. Os documentos em questão, isso é, os editais se manifestam voluntária ou involuntariamente sobre os caminhos que levam as pessoas surdas a acessarem a educação superior, podendo viabilizar a transformação da história de exclusão com a qual esses sujeitos foram submetidos durante longos anos. Sendo assim, em nossa pesquisa os documentos se constituem, conforme descritos por Lüdke e André (1986), concomitantemente, valiosos e decisivos para a abrangência do objeto de investigação.

De acordo com Severino (2007), com relação à natureza das fontes de uma pesquisa é possível classificá-la em bibliográfica, documental, experimental ou de campo. Em nosso estudo optamos pela pesquisa documental ${ }^{62}$, um procedimento metodológico considerado de suma relevância e, muitas vezes, decisivo para a investigação, entretanto ainda pouco explorado na educação, assim como em outras áreas das ciências humanas e sociais (SÁ-SILVA; ALMEIDA; GUINDANI, 2009; LÜDKE; ANDRÉ, 1986).

De acordo com Bardin (1977, p. 45-46), ao tentar responder:

O que é análise documental? Podemos defini-la como <<uma operação ou um conjunto de operações visando representar o conteúdo de um documento sob uma forma diferente da original, a fim de facilitar num estado ulterior, a sua consulta e referenciação > . Enquanto tratamento da informação contida nos documentos acumulados, a análise documental tem por objectivo dar forma conveniente e representar de outro modo essa informação, por intermédio de procedimentos de transformação. O propósito a atingir é o armazenamento sob uma forma variável e a facilitação do acesso ao observador, de tal forma que este obtenha o máximo de informação (aspecto quantitativo), com o máximo de pertinência (aspecto qualitativo).

Nessa perspectiva, em um processo de análise documental o olhar do pesquisador selecionará as informações mais expressivas do conteúdo. Além disso, esse "conjunto de operações”, como denominado por Bardin (1977), permite ao leitor uma interpretação dos documentos cuja leitura será certamente distinta da que se realizaria através do contato, sem nenhum tratamento, com os documentos originais.

\footnotetext{
${ }^{62}$ Apesar do consenso sobre a relevância (e o pouco uso) do trabalho acadêmico com documentos, é válido destacar que a denominação parece ser um conflito na literatura da investigação científica. Segundo Sá-Silva, Almeida e Guindani (2009), alguns estudos tratam como pesquisa documental aquilo que outros aludem por método, técnica, análise documental ou ainda de modo combinado como "método de análise documental". Em consonância com os autores, optamos aqui por adotar o termo pesquisa, pois "quando um pesquisador utiliza documentos objetivando extrair dele informações, ele o faz investigando, examinando, usando técnicas apropriadas para seu manuseio e análise; segue etapas e procedimentos; organiza informações a serem categorizadas; por fim, elabora sínteses [...]" (SÁ-SILVA; ALMEIDA; GUINDANI, 2009, p. 4). Assim, de acordo com os autores, apenas o conceito de pesquisa pode abranger todas essas atividades. Apesar disso, respeitando os textos originais, quando referirmos determinado autor que não compactua com a expressão "pesquisa" documental, utilizaremos a escolha lexical deste.
} 
O trabalho com documentos originais também é abordado por Sá-Silva, Almeida, Guindani (2009) e Severino (2007) ao discutirem sobre a definição de pesquisa documental sob o viés de sua distinção com relação à pesquisa bibliográfica. Para esses autores, ambas têm o documento escrito como objeto de investigação, porém a principal diferença reside em a natureza das fontes. A pesquisa documental com a qual nos alinhamos neste estudo parte do uso de fontes primárias, ou seja, de matéria-prima sem nenhum tratamento analítico anterior. Por outro lado, a pesquisa bibliográfica se beneficia de fontes secundárias, isso quer dizer que são dados que já foram analisados e tratados por outros autores e, atualmente, constituem domínio científico.

Além disso, cumpre destacar que os documentos da pesquisa bibliográfica estão, geralmente, restritos aos textos escritos ou impressos, enquanto a pesquisa documental abrange uma grande variedade de tipos de documentos, tais como: jornais, revistas, diários, fotografias, filmes, pôsteres, slides, vídeos, gravações, leis, regulamentos, pareceres, normas, cartas, memorandos, arquivos escolares, roteiros de programas de rádio ou televisão, discursos, estatísticas, autobiografias e livros (LÜDKE; ANDRÉ, 1986; SEVERINO, 2007; SÁ-SILVA; ALMEIDA; GUINDANI, 2009).

Essa informação é relevante, pois em nosso percurso metodológico, como será descrito mais adiante, propusemo-nos inicialmente a analisar editais de vestibulares, porém, conforme as questões se tornavam mais complexas, apoiamo-nos também em outros documentos do processo seletivo, dentre os quais alguns escritos e outros em formato de vídeos, tais como as provas e editais em Libras.

Em consonância com estudiosos como Sá-Silva, Almeida, Guindani (2009), Lüdke e André (1986) existem inúmeras contribuições no uso do documento como fonte para o pesquisador das ciências sociais. Segundo os autores as vantagens da pesquisa documental podem ser adotadas de dois modos, ou seja, de forma complementar a outras técnicas de pesquisa, ampliando ou fortalecendo informações obtidas por meio de outros instrumentos metodológicos ou como a única alternativa viável para se obter informações novas e essenciais. Importa enfatizar que acolhemos a segunda abordagem, isto é, utilizamos os documentos não de forma complementar, mas como produto principal de nossa pesquisa.

Consideramos como vantagens acerca do trabalho com a pesquisa documental, tal como pontuam Lüdke e André (1986), o fato de os documentos se constituírem uma fonte rica e estável, cuja possibilidade de análise persiste ao longo do tempo, permitindo revisitá-lo sempre que necessário. Outra vantagem é a de que os documentos formam uma fonte não reativa, isso significa que sua interação com o pesquisador não irá influenciar seu comportamento ou ponto 
de vista, embora o olhar do pesquisador não possa ser consideradox' neutro. E, por fim, a pesquisa documental representa um baixo custo, pois o investimento maior reside no tempo e atenção depositados pelo pesquisador durante o processo de seleção e análise (LÜDKE; ANDRÉ, 1986).

Desse modo, em síntese, adotamos nesta pesquisa o uso da abordagem qualitativa em especial no que tange à pesquisa documental, alinhados a compreensão mais ampla do conceito de documentos como arquivos da memória coletiva e que estão situados em um contexto sóciohistórico e político. A nosso ver, os documentos têm um papel fulcral no delineamento da história, pois têm o poder de influenciá-la e até de modificá-la (LE GOFF, 2003). Assim, compreendemos que os rumos de uma história de conquistas e reafirmação de direitos das pessoas surdas estão em jogo e podem ser desvelados sob a contribuição da análise de documentos, tais como os editais de processos seletivos de cursos de graduação voltados para a formação de professores de Libras. No entanto, a seleção dos editais e de documentos complementares ao processo seletivo não foi realizada aleatoriamente, conforme Lüdke e André (1986), o pesquisador qualitativo precisa conhecer profundamente o contexto de pesquisa para agir sobre ele. Tendo isso em vista, na sequência, apresentamos o contexto no qual esta pesquisa encontra-se situada.

\subsection{O CONTEXTO DA PESQUISA}

A fim de investigar e analisar o acesso dos surdos a cursos superiores de formação de professores de Libras, preliminarmente, foi necessário realizar um levantamento das IES e dos cursos de Pedagogia bilíngue e Letras Libras ofertados no país na última década. Para isso, realizamos na base de dados do e-MEC ${ }^{63}$ um levantamento das IES e das ofertas de cursos para

\footnotetext{
${ }^{63}$ A escolha pelo e-MEC ocorreu em virtude de este ser um sistema de tramitação eletrônica que permite a abertura e o acompanhamento dos processos de regulação dos cursos e das IES, tal como o credenciamento e recredenciamento das IES ou a autorização, reconhecimento e renovação do reconhecimento de cursos (BRASIL, 2015a). Embora o e-MEC, em funcionamento desde 2007, represente uma ferramenta útil para a consulta de IES e cursos regularmente cadastros junto ao MEC, estamos conscientes de que, em conformidade com o $\S 4^{\circ}$ do Art. 13 do Decreto $\mathrm{n}^{\circ} 5.773$, de 9 de maio de 2006 (BRASIL, 2006a), é permitido que o primeiro credenciamento para as faculdades ocorra em um prazo máximo de três anos. Sendo assim, está sob nosso conhecimento a existência da oferta de cursos de formação de professores de Libras que não apareceram no resultado da consulta ao e-MEC como, por exemplo, o curso denominado Licenciatura em Língua de sinais brasileira/português como segunda língua ofertado pela Universidade Nacional de Brasil (UnB) desde o segundo semestre de 2014 (UNIVERSIDADE NACIONAL DE BRASÍLIA 2014a, 2014b). Entretanto, diante da dificuldade em localizar outra base na qual seria possível elencar todos os cursos, incluindo os ainda não cadastrados junto ao MEC, estabelecemos como recorte o levantamento de IES e cursos cadastrados, exclusivamente, no referido sistema.
} 
Letras Libras e Pedagogia bilíngue cadastradas no país, optando pelo recorte temporal do período entre 2005 até $2015^{64}$.

Para determinar a busca no sistema eletrônico do e-MEC, embasamo-nos no Decreto $\mathrm{n}^{\circ}$ 5.626/05 (BRASIL, 2005), cuja regulamentação estabelece que a graduação para formação de professores de Libras é formalizada por intermédio de cursos de Pedagogia ou curso normal superior, nos quais a Libras e a modalidade escrita da Língua Portuguesa tenham representado as línguas de instrução, ou de cursos de licenciatura em Letras com habilitação em Libras ou em Libras/Língua Portuguesa como segunda língua para surdos.

Nesse viés, com o intuito de identificarmos os cursos de educação superior voltados à formação de professores de Libras e suas respectivas IES, realizou-se um levantamento na base de dados do e-MEC, onde localizamos 34 IES, sendo 27 instituições públicas (duas estaduais e 25 federais) e sete instituições privadas. Vinculam-se a essas 34 instituições de educação um total de 38 cursos de graduação autorizados pelo MEC voltados para a formação de professores de Libras, sendo 36 cursos de licenciatura em Letras Libras e dois cursos bilíngues de Pedagogia ${ }^{65}$. Convém salientar que, em algumas situações, verificamos um mesmo curso ofertado pela IES ter mais de um registro no e-MEC. O levantamento do número de cursos e de IES localizadas são representados na Tabela 4.1.

Tabela 4.1 - Relação de IES e cursos cadastrados no e-MEC voltados para a formação de professores de Libras

(continua)

\begin{tabular}{|c|c|c|c|}
\hline \multirow{2}{*}{\multicolumn{2}{|c|}{$\frac{\text { Instituições (Qtd.) }}{\text { Categoria }}$}} & \multicolumn{2}{|r|}{ Curso (Qtd.) } \\
\hline & & Modalidade & Grau \\
\hline \multirow{2}{*}{$\begin{array}{l}\text { IES Públicas } \\
\text { (27) }\end{array}$} & $\begin{array}{c}\text { IES } \\
\text { Estaduais (2) }\end{array}$ & Presencial (4) & $\begin{array}{l}\text { Licenciatura em Letras com habilitação em } \\
\text { língua portuguesa e Libras (3) } \\
\text { Licenciatura em Letras com habilitação em } \\
\text { Libras (1) }\end{array}$ \\
\hline & $\begin{array}{l}\text { IES Federais } \\
\quad(25)\end{array}$ & A distância (4) & $\begin{array}{l}\text { Licenciatura em Letras com habilitação em } \\
\text { Libras ( } 2 \text { ) } \\
\text { Licenciatura em Letras com habilitação em } \\
\text { língua portuguesa e Libras (2) }\end{array}$ \\
\hline
\end{tabular}

\footnotetext{
${ }^{64}$ A escolha desse recorte temporal se deu, pois data de 2005 o ano em que o Decreto $n^{\circ}$ 5.626/05 (BRASIL, 2005) foi promulgado, documento no qual os cursos de formação de professores de Libras foram estabelecidos. Por sua vez, o ano de 2015 consistiu no ano em que nosso levantamento junto ao e-MEC foi realizado. Ressalta-se que a consulta ao e-MEC foi realizada durante o período de 25 de fevereiro de 2015 a 6 de março de 2015.

${ }^{65}$ Durante o levantamento junto ao e-MEC localizamos outros seis cursos de Letras com habilitação em Libras, entretanto, foram desconsiderados no cômputo desta pesquisa, pois se tratavam de cursos de bacharelado e, portanto, em consonância com o Decreto $n^{\circ}$ 5.626/05 não sendo caracterizados como cursos de formação de professores de Libras. Dentre os seis cursos de bacharelado em Letras com habilitação em Libras identificados no e-MEC temos: a) dois cursos oferecidos pela Ufsc (um na modalidade presencial e um na modalidade a distância); b) um curso oferecido pela Universidade Federal do Rio de Janeiro (UFRJ); c) um curso oferecido pela Universidade Federal do Espírito Santo; d) um curso oferecido pela Universidade Federal do Mato Grosso (UFMT); e e) um curso oferecido pela Universidade Federal de Roraima (UFRR).
} 
Tabela 4.1 - Relação de IES e cursos cadastrados no e-MEC voltados para a formação de professores de Libras

(conclusão)

\begin{tabular}{|c|c|c|}
\hline \multirow{2}{*}{$\begin{array}{c}\text { Instituições (Qtd.) } \\
\text { Categoria }\end{array}$} & \multicolumn{2}{|r|}{ Curso (Qtd.) } \\
\hline & Modalidade & Grau \\
\hline \multirow{4}{*}{$\begin{array}{l}\text { IES Públicas } \\
\qquad(27)\end{array}$} & & $\begin{array}{c}\text { Licenciatura em Letras com habilitação em } \\
\text { língua portuguesa e Libras (3) } \\
\text { Licenciatura em Letras com habilitação em } \\
\text { Libras (17) }\end{array}$ \\
\hline & Presencial (23) & $\begin{array}{l}\text { Licenciatura em Letras com habilitação em } \\
\text { língua portuguesa com domínio em Libras } \\
\text { (1) }\end{array}$ \\
\hline & & Licenciatura em Pedagogia Bilíngue (1) \\
\hline & & Licenciatura em Pedagogia (1) \\
\hline \multirow[t]{2}{*}{ IES Privadas (7) } & Presencial (7) & $\begin{array}{c}\text { Licenciatura em Letras com habilitação em } \\
\text { Libras (2) }\end{array}$ \\
\hline & & $\begin{array}{c}\text { Licenciatura em Letras com habilitação em } \\
\text { língua portuguesa e Libras (5) }\end{array}$ \\
\hline
\end{tabular}

A distribuição, por estados, de cursos de graduação voltados à formação de professores de Libras, autorizados pelo MEC, é ilustrada na representação do Mapa 4.1.

Mapa 4.1 - Mapa representativo da distribuição de cursos de graduação para formação de professores de Libras distribuídos por estado com base nos dados extraídos do eMEC (2015)

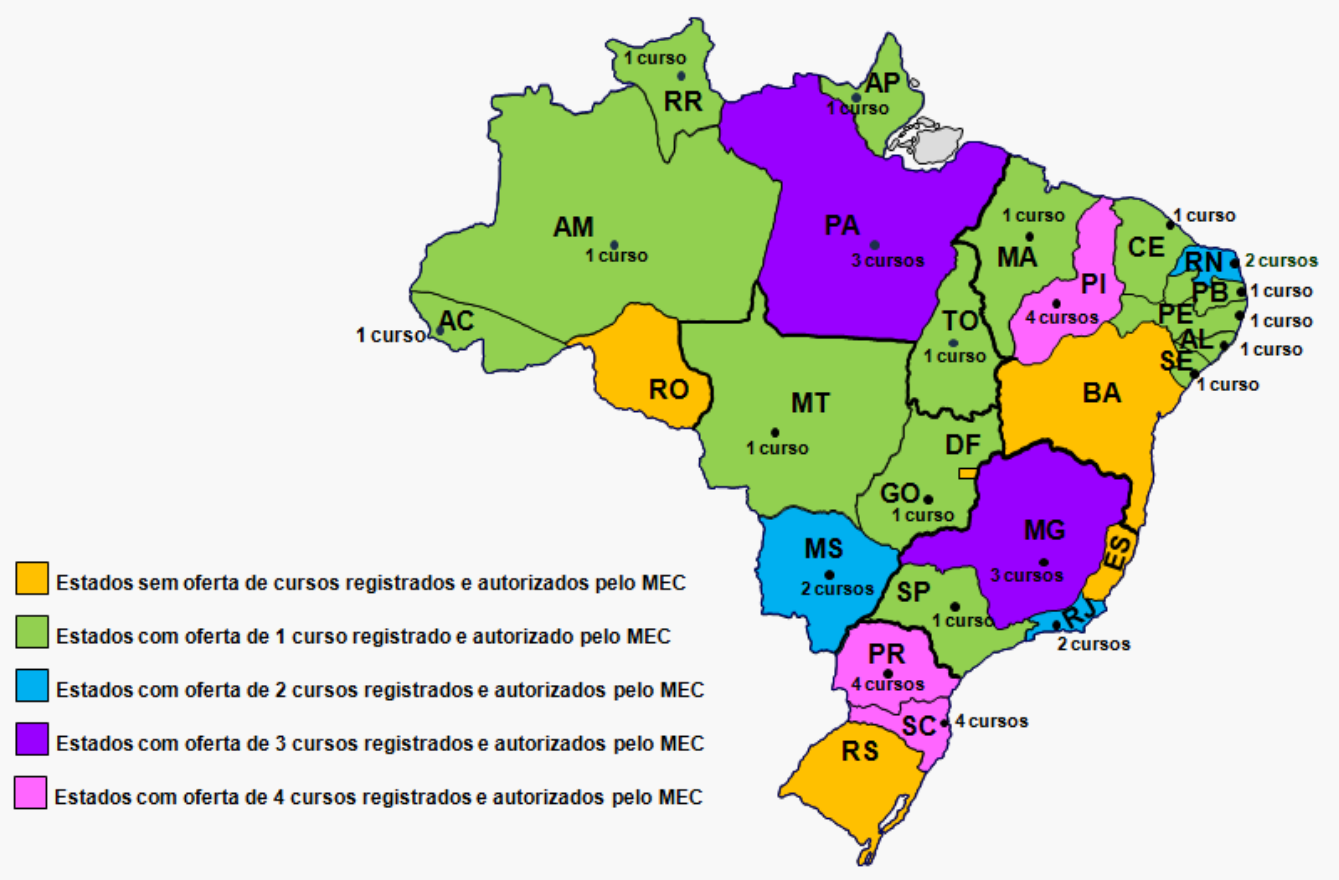

Cumpre destacar, porém que, dentre os 36 mencionados cursos de licenciatura em Letras Libras, quatro são ofertados na modalidade de EaD para um montante de 27 polos. Assim, em Mato Grosso do Sul, a Universidade Federal da Grande Dourados (UFGD) possui dois cursos 
autorizados pelo MEC, sendo distribuídos em três municípios do mesmo estado, a saber: 1) Bataguassu; 2) Dourados e 3) Rio Brilhante. Da mesma forma, a Universidade Federal da Paraíba (UFPB) possui, por meio de um único curso autorizado pelo MEC a distribuição em seis municípios do mesmo estado: 1) Cabeceiras; 2) Campina Grande; 3) Itaporanga; 4) João Pessoa; 5) Pombal; e 6) Taperoá. ${ }^{66}$

Entre as IES que ofertam cursos de graduação para a formação de professores de Libras, seguramente, destaca-se a Ufsc, pelo pioneirismo e pela abrangência na oferta de cursos que atendeu 18 municípios pertencentes a 16 estados diferentes, sendo: 1) Manaus/AM; 2) Salvador/BA; 3) Fortaleza/CE; 4) Brasília/DF; 5) Vitória/ES; 6) Goiânia/GO; 7) Belo Horizonte/MG; 8) Dourados/MS; 9) Belém/PA; 10) Recife/PE; 11) Curitiba/PR; 12) Rio de Janeiro/RJ; 13) Natal/RN; 14) Porto Alegre/RS; 15) Santa Maria/RS; 16) Florianópolis/SC; 17) Campinas/SP; e 18) São Paulo/SP ${ }^{67}$. A distribuição dos cursos de graduação para formação na licenciatura em Letras Libras, ofertados na modalidade EaD pela Ufsc, é representada no Mapa $4.2^{68}$.

Mapa 4.2 - Mapa representativo da distribuição de cursos de Letras com habilitação em Libras ofertados pela Ufsc com base nos dados extraídos do e-MEC (2015)

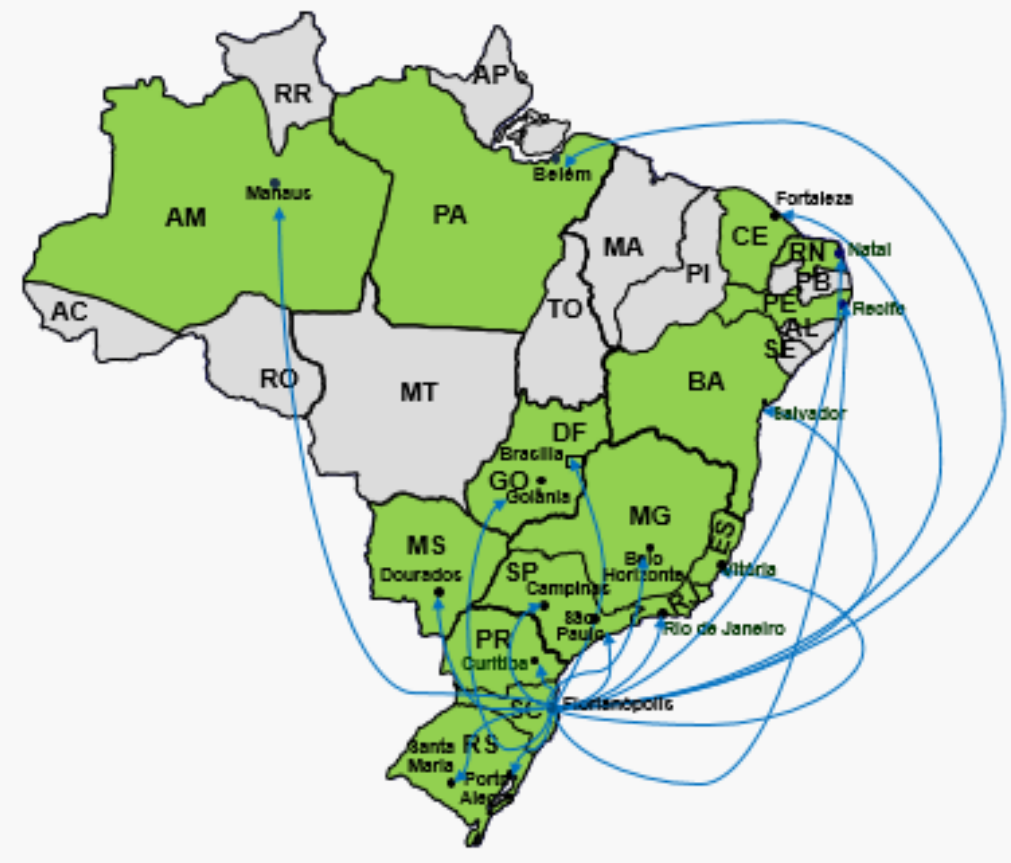

\footnotetext{
${ }^{66}$ Apesar de constar no e-MEC a autorização para o curso em seis municípios da Paraíba, durante a análise dos editais, verificamos que a oferta de cursos da UFPB ultrapassou esse quantitativo, pois além desses foram abertas vagas nos polos situados em Alagoa Grande/PB, Camaçari/BA, Conde/PB, Coremas/PB, Duas Estradas/PB, Cuité de Mamanguape/PB e Esplanada/BA.

${ }^{67}$ Apesar de constar no e-MEC a autorização do curso da Ufsc para esses 18 municípios, durante a análise dos editais, verificamos a oferta de cursos em outros três municípios: Joinville/SC, Santa Rosa/RS e São Luis/MA.

${ }^{68}$ Cotejando os mapas, é possível perceber que o único estado do país que não é atendido por nenhum curso de graduação para formação de professores de Libras, seja na modalidade presencial ou a distância, conforme dados do e-MEC, é Rondônia.
} 
Desse modo, sob os pressupostos da pesquisa documental e com base no levantamento de IES e de cursos de graduação autorizados pelo MEC para a formação de professores de Libras, iniciamos uma busca eletrônica preliminar pelos editais de processos seletivos. No decorrer da pré-seleção, tivemos maior dificuldade de encontrar os editais anteriores referentes às instituições privadas, inclusive ao recorrermos ao contato via endereço eletrônico não obtivemos êxito.

Diante do exposto, e considerando a maior ingerência no âmbito federal de documentos legais como, por exemplo, o Decreto $n^{\circ} 5.626 / 05$ (BRASIL, 2005) e o Decreto $\mathrm{n}^{0} 3.298 / 99$ (BRASIL, 1999) que favorecem o acesso dos surdos à educação superior, nesta pesquisa, em nosso recorte por IES, optamos por focalizar a prioridade atribuída aos surdos nos processos seletivos para ingresso nos cursos de formação de professores de Libras referente às 25 Ifes e seus respectivos 27 cursos para formação de professores de Libras, sendo dois cursos bilíngues de Pedagogia e 25 cursos de Letras Libras, incluindo aqueles oferecidos na modalidade a distância.

Portanto, são Ifes participantes da presente pesquisa: 1) Universidade Federal do Paraná (UFPR); 2) Universidade Federal da Grande Dourados (UFGD); 3) Universidade Federal do Rio de Janeiro (UFRJ); 4) Universidade Federal de Juiz de Fora (UFJF); 5) Universidade Federal de Uberlândia (UFU); 6) Universidade Federal de Goiás (UFG); 7) Universidade Federal de Santa Catarina (Ufsc); 8) Instituto Federal de Educação, Ciência e Tecnologia de Goiás (IFG); 9) Universidade Federal do Mato Grosso (UFMT); 10) Fundação Universidade Federal do Tocantins (UFT); 11) Universidade Federal do Acre (Ufac); 12) Universidade Federal do Amazonas (Ufam); 13) Universidade Federal do Pará (UFPA); 14) Universidade Federal do Amapá (Unifap); 15) Universidade Federal do Maranhão (UFMA); 16) Universidade Federal do Piauí (UFPI); 17) Universidade Federal do Ceará (UFC); 18) Universidade Federal Rural do Semiárido (Ufersa); 19) Universidade Federal do Rio Grande do Norte (UFRN); 20) Universidade Federal de Pernambuco (UFPE); 21) Universidade Federal da Paraíba (UFPB); 22) Universidade Federal de Alagoas (Ufal); 23) Universidade Federal de Sergipe (UFS); 24) Instituto Nacional de Educação de Surdos (Ines); e 25) Universidade Federal Rural da Amazônia (Ufra).

Conforme mencionado, inicialmente, realizamos um levantamento das IES no e-MEC adotando como filtro o período entre 2005 a 2015, porém, diante da seleção de Ifes, verificamos que todos os cursos dessas instituições apresentavam data de início ulterior a 2005, o que significa que nosso recorte temporal, na verdade, abrangeu todas as ofertas, desde seus 
primeiros processos seletivos em 2006 até maio de $2015^{69}$. Assim, privilegiada a exposição a respeito de nosso contexto de pesquisa, prosseguimos com a descrição de nossas escolhas e organização no que compete à geração dos dados.

\subsection{A GERAÇÃO DE DADOS}

Vimos denominando por geração (MASON, 1996; BRANDÃO, 2002) de dados o processo que vários autores, tais como Lüdke e André (1986) e Oliveira (2007), referem por coleta de dados, pois em concordância com Brandão (2002, p. 53):

Cada vez menos se utiliza o verbo coletar, seja no âmbito de materiais históricos, seja no da pesquisa de dados demográficos e outros. As escolhas e conceptualização dos pesquisadores constituem elas mesmas um processo de "criação" e "produção" dos materiais e dos dados que se utilizam.

Sob essa lógica, desde a opção pelas instituições federais até a delimitação do recorte temporal são evidências de procedimentos que criamos para a geração de dados. Para Lüdke e André (1986), em uma pesquisa embasada no uso de documentos, a primeira decisão imbuída ao pesquisador durante esse processo se funda na definição do tipo de documento a ser utilizado.

Será do tipo oficial (por exemplo, um decreto, um parecer), do tipo técnico (como um relatório, um planejamento, um livro-texto) ou do tipo pessoal (uma carta, um diário, uma autobiografia)? Envolverá informações de arquivos oficiais ou arquivos escolares? Ou ambos? Será um material instrucional (filme, livro, roteiro de programa) ou um trabalho escolar (caderno, prova, redação)? Incluirá um único tipo desses materiais ou uma combinação deles? (LÜDKE; ANDRÉ, 1986, p. 40).

Em nosso contexto de pesquisa, a seleção dos documentos foi, a princípio, definida a partir do uso de editais de processos seletivos, como já mencionado. A escolha do documento não foi executada aleatoriamente, pois, tal como argumentam Lüdke e André (1986, p. 40), "há geralmente alguns propósitos, ideias ou hipóteses guiando a sua seleção." Nessa esteira, entendemos que os editais são documentos fulcrais na decisão do ingresso de candidatos surdos aos cursos de graduação voltados para a formação de professores de Libras, pois contêm informações que permitem ser manipuladas e analisadas à luz de suas regras e formas de

\footnotetext{
${ }^{69}$ Cabe ressaltar que a finalização do recorte em maio de 2015 se deu, em decorrência do levantamento dos editais ter ocorrido até julho de 2015 e o mês de maio ter sido a data de publicação do último edital localizado.
} 
organização, verificando as condições de acesso e a existência (ou inexistência) de critérios de prioridade dos sujeitos surdos.

Assim, no que tange ao corpus $^{70}$ de editais de processos seletivos para ingresso em cursos de graduação para formação de professores de Libras, com base no levantamento e seleção das Ifes que ofertam tais cursos, realizamos a busca online por editais, a partir do acesso às páginas institucionais das Ifes investigadas e também por intermédio do motor de busca virtual do Google ${ }^{71}$.

A seleção online considerou o ano de início de cada um dos cursos autorizados pelo MEC, conforme informações extraídas na base de dados do e-MEC. O resultado consistiu na localização do montante de 80 editais de processos seletivos (vestibulares), referentes aos cursos de 25 Ifes. Cabe salientar que a localização da maioria dos editais ocorreu pela consulta ao Google e pela visita ao sítio eletrônico das Ifes, com exceção de oito editais do Ines, referentes aos processos seletivos de 2006 a 2012, que foram localizados apenas no Diário Oficial da União (DOU).

Durante a busca pelos editais complementamos nossa primeira planilha, desenvolvida durante o levantamento das IES, unificando informações extraídas do e-MEC e dos sítios eletrônicos das Ifes com as seguintes informações: 1) Nome do curso/código e-MEC; 2) Nome da universidade/Código e-MEC; 3) Município(s) autorizado(s); 4) Estado da IES cadastrada no e-MEC; 5) Instituição Pública ou Privada; 6) Modalidade Presencial / EaD; 7) Link de acesso ao e-MEC direto ao curso autorizado; 8) Data de início de funcionamento do curso; 9) Ofertado no(s) ano(s); 10) Quantidade de vagas autorizadas pelo MEC; 11) Quantidade de ofertas vinculadas (especialmente em casos de cursos a distância); 12) Carga horária do curso; 13) Periodicidade/Integralização; 14) Ano do edital impresso localizado; 15) Ano do edital em Libras localizado; 16) Nome do coordenador do curso ${ }^{72}$; e 17) Observações.

Apesar de nosso foco inicial residir na busca pelos editais, conforme acessávamos as páginas dos processos seletivos das Ifes, deparamo-nos com outros documentos vinculados aos editais e, ainda sem termos noção de sua utilidade, optamos por agregá-los ao nosso corpus, pois em concordância com Bauer (2002) as pesquisas não precisam ser sistemas fechados, logo,

\footnotetext{
${ }^{70}$ De acordo com Bardin (1977), após a escolha do gênero de documentos analisados, frequentemente, a etapa seguinte consiste na constituição de um corpus. Para a autora, "o corpus é o conjunto dos documentos tidos em conta para serem submetidos aos procedimentos analíticos. A sua constituição implica, muitas vezes, escolhas, seleções e regras.” (BARDIN, 1977, p. 96, grifo nosso).

${ }^{71}$ O levantamento foi realizado durante o período de 25 de junho de 2015 a 13 de julho de 2015.

${ }^{72}$ Registrávamos o nome e o endereço eletrônico de contato dos coordenadores dos cursos, pois acreditamos que, a princípio, se necessitássemos de informações complementares, poderíamos escrever para estes. Contudo, com exceção do Ines, durante nossa pesquisa, quando buscamos esse recurso enfrentamos muita dificuldade de obter retorno desses profissionais.
} 
novos textos sempre podem ser adicionados. Assim, concebendo a variedade de tipos de documentos desvelados na esteira da pesquisa documental (LÜDKE; ANDRÉ, 1986; SEVERINO, 2007; SÁ-SILVA; ALMEIDA; GUINDANI, 2009), é oportuno destacar que além dos 80 editais de vestibulares, foram reunidos outros 217 documentos anexos e complementares relacionados aos 73 processos seletivos ${ }^{73}$ aqui investigados, dentre eles: vídeos de provas em Libras; vídeos dos editais em Libras; editais de retificação; provas de português e objetivas; gabaritos das provas; resultado das etapas do processo seletivo; resultado das vagas destinadas aos surdos; manual do candidato; Projeto Político Pedagógico do curso; listas de candidatos por vagas; nota de corte por curso; convocação de candidatos para etapas do processo seletivo; listas de candidatos que solicitaram correção diferenciada; modelos de laudo médico para declarar tanto as condições especiais para a prova como a surdez do candidato para fins de critério de prioridade; modelo de declaração de quilombola; modelo de declaração da Fundação Nacional do Índio (Funai); resultado final separado por candidatos surdos e ouvintes; quadro com a distribuição das vagas; conteúdo programático das provas; resultado da entrega das documentações solicitando recursos especiais (hora adicional, correção diferenciada, intérprete de Libras etc.); resultado da perícia médica; inscrição de surdos homologada; pontuações máxima e mínima de candidatos cotistas separado por grupos; requerimento de atendimento diferenciado; demanda por curso; lista de pessoas com deficiências classificadas; candidatos aptos destinados às vagas para surdos; critérios para corrigir a redação; resultado da prova de redação após o recurso; resultado do teste de habilidades específicas; lista de candidatos ausentes; lista de candidatos eliminados; lista de alunos classificados remanejados; resoluções internas; nota técnica; folder; isenção da taxa; segunda chamada; convocações e reclassificações.

\footnotetext{
${ }^{73} \mathrm{O}$ número de processos seletivos é inferior ao número de editais, pois em cinco situações houve mais de um edital para o mesmo processo seletivo: 1) Em 2013 a UFRJ liberou três editais, sendo um geral, no qual se exigia a nota do Exame nacional do ensino médio (Enem) para a seleção dos candidatos, o segundo para a chamada do teste de habilidades específicas exigido para ingresso no curso de Letras Libras, e um terceiro para preenchimento de 36 vagas remanescentes; 2) Em 2013, a UFJF dividiu seu processo seletivo em dois, sendo o primeiro para 30\% das vagas e um edital complementar; 3) Em 2013, a UFU lançou um edital de abertura informando a complementação do mesmo a partir de diferentes grupos de seleção, sendo um para o Sistema de Seleção Unificada (Sisu), outro para o Programa de Ação Afirmativa de Ingresso no Ensino Superior (Paaes) e um último para cursos que exigiam certificação de habilidades específicas. Considerando que o curso de Letras Libras não se encaixava neste último, foram analisados os editais de abertura, o do Sisu e o do Paaes; 4) Em 2012-2, a Ufsc dividiu o processo seletivo em dois editais, sendo um para a concorrência geral e outro para atender as políticas de ações afirmativas, ambos foram analisados nesta pesquisa; 5) Em 2015, a Ufam dividiu o seu edital em dois, sendo um direcionado para o Sisu e outro para o processo seletivo contínuo. O processo seletivo contínuo trata-se de um processo seriado promovido pela Ufam no qual avalia os alunos do $1^{\circ}$ ao $3^{\circ}$ ano do Ensino Médio, a soma dos resultados ao longo dos anos decide a aprovação do candidato.
} 
Os editais permaneceram sendo nosso principal instrumento de consulta e análise, porém, na medida em que analisávamos os dados, vários questionamentos foram deflagrados e a observância dos documentos complementares se revelaram de grande valia para obtermos uma visão mais apurada do contexto investigado.

Sendo aclarados os procedimentos de nossa geração dos dados, na próxima seção elucidamos sobre nossas escolhas envolvendo a análise dos dados, pela qual nos alinhamos, sobretudo, aos pressupostos teóricos da análise de conteúdo (BARDIN, 1977; BAUER, 2002).

\subsection{A ANÁLISE DOS DADOS}

Para conduzirmos a análise dos dados, compactuamos com Lüdke e André (1986) e com Sá-Silva, Almeida e Guindani (2009) ao conceberem a análise de conteúdo como o procedimento metodológico que, geralmente, melhor se adéqua à proposta da pesquisa documental. Segundo Bardin (1977, p. 31), "a análise de conteúdo é um conjunto de técnicas de análise das comunicações". Semelhantemente, nas palavras de Bauer (2002, p. 190):

A análise de conteúdo é apenas um método de análise de texto desenvolvido
dentro das ciências sociais empíricas. Embora a maior parte das análises
clássicas de conteúdo culminem [sic] em descrições numéricas de algumas
características do corpus do texto, considerável atenção está sendo dada aos
"tipos", "qualidades", e "distinções" no texto, antes que qualquer
quantificação seja feita. Deste modo, a análise de texto faz uma ponte entre
um formalismo estatístico e a análise qualitativa dos materiais. No divisor
quantidade/qualidade das ciências sociais, a análise de conteúdo é uma técnica
híbrida que pode mediar esta improdutiva discussão sobre virtudes e métodos.

Assim, em concordância com Bauer (2002, p. 190), muitas vezes, a análise de conteúdos é vinculada ao tratamento estatístico das unidades de texto, mas, na verdade, antes de qualquer quantificação, confronta os conteúdos sob a busca de "tipos", "qualidades" e "distinções". Gil (2002) esclarece que a análise de conteúdo pode ser concebida como quantitativa ou qualitativa. No viés quantitativo, enumeram-se e se quantificam automaticamente, por softwares como o Sphinx, unidades lexicais referenciadas no texto e mensuradas com precisão para descrever os fenômenos estudados. Contudo, em nossa pesquisa, adotamos a análise de conteúdo de cunho qualitativo, em que, segundo esse autor, nota-se um diálogo constante entre a interpretação dos dados e a reflexão com o referencial teórico previamente apresentado. Nesse aspecto, a redação se torna mais complexa, pois não se segue uma ordenação tão "lógica" do trabalho a partir de testes de hipóteses estatísticas (GIL, 2002). 
De acordo com Bauer (2002, p. 194), existem seis delineamentos de pesquisa de análise de conteúdos, sendo que sob o seu ponto de vista “o mais simples, e menos interessante, é o estudo puramente descritivo, que conta a frequência de todas as características codificadas do texto." Alude o autor, ainda, que outros delineamentos mais interessantes estão presentes na análise de conteúdo, tais como as análises normativas que realizam comparações de documentos em busca de padrões e as análises transeccionais, na qual se confrontam partes de textos de diferentes contextos sob um curto período de tempo, por exemplo, durante um ou dois meses. Há também as análises longitudinais que abordam o mesmo contexto em um longo período de tempo, isto "[...] permite detectar flutuações, regulares e irregulares, no conteúdo, e inferir mudanças concomitantes no contexto.” (BAUER, 2002, p. 195).

$\mathrm{Na}$ presente pesquisa, buscamos com frequência nos orientarmos por uma análise de conteúdo longitudinal, por compreender que os editais de diferentes instituições e suas respectivas publicações ao longo dos anos permitem analisar um mesmo tema (os processos seletivos realizados para ingresso em cursos de graduação para formação de docentes de Libras) em diferentes contextos (cotejando instituições federais de vários estados do país) e sob um longo período de tempo (sendo o primeiro edital de processo seletivo encontrado com data de 2006 e o último do ano de 2015).

No entanto, além de verificar as flutuações dos processos seletivos ao longo dos anos, durante nosso percurso metodológico conduzido pela análise de conteúdo, concordamos com a afirmação de Lüdke e André (1986), de que se trata de uma técnica de pesquisa que possibilita a realização de inferências sobre o contexto investigado, por meio do conteúdo simbólico das mensagens, que, por sua vez, podem ser abordadas sob diferentes formas e ângulos de análise.

Nesse percurso, Lüdke e André (1986) defendem que a primeira etapa na análise de conteúdos consiste na decisão sobre a unidade de análise, que pode ser a partir de uma unidade de registro ou de uma unidade de contexto. Na unidade de registro a verificação será guiada pela frequência com que um tópico ou tema emerge no texto, enquanto na unidade de contexto pode ser considerado mais relevante observar, além da frequência, o contexto no qual a unidade está situada.

Diante de nosso corpus, foram definidas 39 unidades de análise, algumas guiadas pela unidade de registro e outras pela unidade de contexto, são elas: 1) Número do edital (conforme representado no próprio documento) (unidade de registro); 2) Ano e semestre de divulgação do edital (unidade de registro); 3) Ano e semestre de ingresso no curso (unidade de registro); 4) Percentual de preenchimento de vagas do edital (pois alguns processos seletivos se dividiram em dois ou mais editais, sendo cada destinado a preencher um percentual de vagas) (unidade de 
registro); 5) Forma de ingresso (se o processo seletivo era via edital geral, específico, Sisu, Plano Nacional de Formação de Professores da Educação Básica (Parfor) etc.) (unidade de registro); 6) Nome da instituição (unidade de registro); 7) Responsável pela organização do processo seletivo (unidade de registro); 8) Fundamentação interna legal (muitas vezes os editais se basearam em resoluções internas da Ifes, a qual obtendo essa informação buscamos consultar $^{74}$ ) (unidade de contexto); 9) Forma de oferta/modalidade (presencial ou a distância) (unidade de registro); 10) Município(s) ofertado(s) (unidade de registro); 11) Estado(s) (unidade de registro); 12) Nome do curso (unidade de registro); 13) Quantidade total de vagas ofertadas (unidade de registro); 14) Distribuição das vagas ofertadas ${ }^{75}$ (unidade de contexto); 15) Requisitos para o ingresso (unidade de contexto); 16) Requisitos para o ingresso (unidade de registro); 17) Prioridade para surdos na classificação (unidade de contexto); 18) Prioridade para surdos na classificação (unidade de registro); 19) Critérios para atender a prioridade e/ou ter as condições de acessibilidade atendidas (unidade de contexto); 20) Condições de acessibilidade para surdos (unidade de contexto); 21) Prova em Libras (unidade de registro); 22) Tempo adicional (unidade de registro); 23) Uso do Aparelho de Amplificação Sonora Individual (Aasi) (unidade de registro); 24) Prova diferenciada de Língua Portuguesa (unidade de registro); 25) Solicitação de candidato de condições especiais (unidade de registro); 26) Aproveitamento da nota do Enem (unidade de contexto); 27) Aproveitamento da nota do Enem (unidade de registro); 28) Edital disponível em Libras (unidade de registro); 29) Exigência de pré-conhecimento em Libras aos candidatos (unidade de registro); 30) Modo de aferir préconhecimento em Libras (unidade de contexto); 31) Organização das provas (unidade de contexto); 32) Previsão de recurso para surdos referente à correção da redação (unidade de contexto); 33) Previsão de recurso para surdos referente à correção da redação (unidade de registro); 34) Cruzamento entre a PAA e a prioridade para surdos (unidade de registro); 35) PAA (unidade de contexto); 36) PAA (unidade de registro); 37) Outros comentários e observações pertinentes (unidade de contexto); 38) Arquivos extras localizados (unidade de contexto); e 39) Quantidade de arquivos extras localizados (unidade de registro).

\footnotetext{
${ }^{74}$ Como exemplo da contribuição do registro dessa unidade de análise é possível citar que a UFPB não indicava informações em seu edital sobre a prova de Língua Portuguesa feita por candidatos surdos ser corrigida diferenciadamente por banca de profissionais competentes, mas na resolução interna em que o referido documento se alicerçava, tais informações estavam explicitadas, o que nos permitiu inferir a existência de tal condição de acessibilidade.

${ }^{75}$ Enquanto na $13^{\mathrm{a}}$ unidade de análise vislumbramos o número total de vagas, na $14^{\mathrm{a}}$ discriminamos, quando houve, o quantitativo destinado especificamente aos surdos, aos professores ou à cota de Política de Ação Afirmativa (PAA).
} 
Todas as unidades foram distribuídas em colunas de uma planilha eletrônica e, como denotado, algumas unidades de análise foram duplicadas para ora serem reconhecidas como unidades de contexto ora como unidades de registro (LÜDKE; ANDRÉ, 1986). Estamos considerando como unidades de contexto as células em que o registro consistiu, por exemplo, em excertos de parágrafos do edital, onde o elemento disparador em questão estava contido. Por outro lado, as unidades de registro estão sendo entendidas como aquelas em que o preenchimento foi realizado de modo a permitir que dentro da planilha eletrônica seja aplicado o filtro com base em sua recorrência. Para ilustrar essa passagem, é possível pensar nas mencionadas unidades de análise 26 e 27 relacionadas ao aproveitamento da nota do Enem.

$\mathrm{Na}$ unidade de contexto 26, replicamos o parágrafo do texto em que se encontrava a orientação sobre como foi realizado o aproveitamento da nota do Enem no processo seletivo, isso foi útil para conferir o contexto no qual a decisão constava. Já na unidade de registro 27 o preenchimento se limitava a indicar "parcial" (para aqueles processos seletivos em que a nota do Enem era parcialmente aproveitada), "integral" (para os processos seletivos em que a nota do Enem era o único critério de seleção adotado), "nada consta" ou "não realiza", medida que nos auxiliava a mensurar a recorrência da unidade, por meio da ferramenta de "filtro" da planilha eletrônica.

Esse procedimento partiu dos preceitos de Lüdke e André (1986, p. 41), para quem na análise de conteúdo:

Pode, por exemplo, haver variações na unidade de análise, que pode ser a palavra, a sentença, o parágrafo ou o texto como um todo. Pode também haver variações na forma de tratar essas unidades. Alguns podem preferir a contagem de palavras ou expressões, outros podem fazer análise da estrutura lógica de expressões e elocuções e outros, ainda podem fazer análises temáticas. $\mathrm{O}$ enfoque da interpretação também pode variar. Alguns poderão trabalhar os aspectos políticos da comunicação, outros os aspectos psicológicos, outros, ainda, os literários, os filosóficos, os éticos e assim por diante.

Cumpre salientar que as 39 unidades de análise foram construídas na medida em que explorávamos os editais de vestibulares, tendo em vista que serviram como nosso principal documento de análise. Entretanto, como exposto anteriormente, além dos 80 editais, houve outros documentos complementares aos quais recorremos em diversos momentos. Para o registro desses utilizamos o processador de textos Microsoft Word, ferramenta que nos foi útil também para manipular longos excertos de editais que se tornavam ininteligíveis na planilha eletrônica. O processador de textos acabou se tornando um espelho da planilha eletrônica, no 
qual inseríamos, concomitantemente, todos os excertos dos editais, embora nele fosse possível não só incorporar informações adicionais dos documentos complementares, anotar reflexões pessoais, bem como realizar grifos e inserir comentários (semelhante às características e à flexibilidade de um diário de campo).

Além disso, em nosso percurso metodológico, buscamos nos guiar pela perspectiva de Bardin (1977), para quem a análise de conteúdo se organiza em três etapas, sendo: $1^{\text {a }}$ a préanálise; $2^{\mathrm{a}}$ a exploração do material; e $3^{\mathrm{a}}$ o tratamento dos resultados, a inferência e a interpretação. A primeira etapa descrita pela autora consiste basicamente na escolha dos documentos, seguida de uma leitura flutuante (com intuito de entrar em contato com o texto, extraindo as primeiras impressões e orientações) e da formulação de indicadores, hipóteses e objetivos. Certamente, essas são tarefas interligadas, pois a escolha dos documentos depende dos objetivos da pesquisa, assim como os indicadores serão determinados em função das hipóteses e as hipóteses serão construídas a partir da presença de certos índices (BARDIN, 1977).

De acordo com Lucke e André (1986, p. 13), a análise dos dados de uma pesquisa qualitativa “[...] tende a seguir um processo indutivo. Os pesquisadores não se preocupam em buscar evidências que comprovem hipóteses definidas antes do início dos estudos." Logo, as hipóteses podem ser construídas a partir da interação do pesquisador com os dados, concatenando as evidências às orientações do quadro teórico.

A esse respeito, Bardin (1977, p. 98) confirma que, de fato, as hipóteses ${ }^{76}$ nem sempre são determinadas a priori, muitas vezes, é possível iniciar a análise dos dados "às cegas", isto é, “sem ideias preconcebidas". Mas, do mesmo modo, também é possível que haja por parte do pesquisador hipóteses já arquitetadas antes da análise dos dados, especialmente, a partir do quadro teórico ou pragmático construído. Neste sentido, a etapa da pré-análise pode favorecer esse processo de formulação de hipóteses e objetivos. E, seguindo tais orientações, ao entrarmos em contato com os textos da revisão bibliográfica ou com os primeiros editais de vestibulares, já pudemos eleger algumas hipóteses a respeito de nossos objetivos, para mais tarde confrontálas ao panorama geral de nossos resultados e assim serem refutadas ou confirmadas, ainda que parcialmente.

Na segunda etapa da análise de conteúdo proposta por Bardin (1977), a exploração do material tende a ser uma tarefa de grande dedicação de tempo e de esforço intelectual por parte

\footnotetext{
${ }^{76}$ Para Bardin (1977), as hipóteses se constituem em afirmações provisórias elaboradas pelo pesquisador, de origem intuitiva, e que serão confirmadas ou infirmadas quando submetidas à prova diante dos dados.
} 
do investigador, pois é desenvolvida por intermédio de operações de codificação, desconto ou enumeração dos dados. Nessa etapa, conforme salientam Lüdke e André (1986, p. 42), o pesquisador realiza exaustivas leituras e releituras do material, buscando detectar temas e temáticas que surgem com maior frequência no texto analisado. A recorrência de determinados aspectos ou informações, temas que aparecem em diferentes situações ou contextos podem ser agrupados para a construção de categorias ou tipologias. Segundo as autoras, essa construção de categorias é essencialmente indutiva e criativa, visto que cabe ao pesquisador julgar de forma cautelosa os aspectos mais relevantes e significativos dos dados. É possível elaborar as categorias, a princípio, sob o suporte do quadro teórico, mas ao longo do processo será necessário examiná-las e confrontá-las teórica e empiricamente com assiduidade.

No rastro dessa lógica, após o preenchimento das planilhas e anotações no processador de texto envolvendo as unidades de análise, seguimos para um intenso processo de leituras e releituras dos dados construídos, confrontando-os à luz da fundamentação teórica e legal desta pesquisa. Esse constante exercício de reflexão nos permitiu, de modo indutivo, reunir os dados em três grandes eixos, a saber: 1) Caracterização dos processos seletivos; 2) Condições de acessibilidade; e 3) A disposição de vagas para surdos.

Desses três eixos derivaram 11 categorias e três subcategorias de análises representadas através da Tabela 4.2 .

Tabela 4.2 - Representação dos eixos, categorias e subcategorias de análise (continua)

Eixos

\begin{tabular}{ccc}
\hline & $\begin{array}{c}\text { O panorama da oferta de } \\
\text { cursos de Letras Libras e } \\
\text { Pedagogia bilíngue de 2006 } \\
\text { a } 2015\end{array}$ \\
\hline Caracterização dos processos & $\begin{array}{c}\text { Organização da forma de } \\
\text { ingresso adotada para os } \\
\text { seletivos } \\
\text { cursos de Letras Libras e } \\
\text { Pedagogia bilíngue entre } \\
\text { 2006 a 2015 }\end{array}$ \\
& Requisitos para o ingresso \\
nos cursos de Letras Libras e & A prova de conhecimentos \\
Pedagogia bilíngue entre & em/sobre Libras \\
2006 a 2015 &
\end{tabular}


Tabela 4.2 - Representação dos eixos, categorias e subcategorias de análise

(conclusão)

\begin{tabular}{|c|c|c|}
\hline Eixos & Categorias & Subcategorias \\
\hline \multirow{6}{*}{ Condições de acessibilidade } & \multicolumn{2}{|l|}{ Editais traduzidos em Libras } \\
\hline & \multicolumn{2}{|l|}{$\begin{array}{l}\text { Intérprete de Libras e/ou } \\
\text { projeção da prova em Libras }\end{array}$} \\
\hline & \multicolumn{2}{|l|}{ Tempo adicional } \\
\hline & \multicolumn{2}{|l|}{ Uso do Aasi } \\
\hline & $\begin{array}{c}\text { Prova de língua portuguesa } \\
\text { diferenciada }\end{array}$ & $\begin{array}{l}\text { Interposição de recursos à } \\
\text { prova de redação }\end{array}$ \\
\hline & $\begin{array}{l}\text { Requisitos para obtenção do } \\
\text { direito de acessibilidade e/ou } \\
\text { prioridade }\end{array}$ & \\
\hline \multirow{2}{*}{$\begin{array}{l}\text { A disposição de vagas para } \\
\text { surdos }\end{array}$} & $\begin{array}{c}\text { A interpretação da } \\
\text { prioridade dos candidatos } \\
\text { surdos }\end{array}$ & $\begin{array}{l}\text { Preenchimento das vagas } \\
\text { destinadas aos candidatos } \\
\text { surdos }\end{array}$ \\
\hline & $\begin{array}{c}\text { Cruzamento entre a } \\
\text { prioridade para surdos e a } \\
\text { PAA }\end{array}$ & \\
\hline
\end{tabular}

Em consonância com Bauer (2002), nossa análise de conteúdo visou articular as informações provenientes do texto, observando a pertinência de tópicos relacionados ao nosso objeto de pesquisa, bem como sua recorrência nos diferentes editais analisados.

Nessa direção, acompanhando as orientações sobre a terceira etapa de "tratamento dos resultados obtidos e interpretação", Bardin (1977, p. 101) descreve que "os resultados brutos são tratados de maneira a serem significativos $(<<$ falantes $>>)$ e válidos" e podem se beneficiar de recursos diversos como, por exemplo, quadros, diagramas, figuras e modelos que organizem as informações obtidas durante a análise. Assim, como será visto no Capítulo 5 adotamos, continuamente, o recurso de gráficos e tabelas, além de excertos dos editais e provas, com intuito de compilar e demonstrar de forma ilustrativa os dados analisados.

Por fim, seguindo as orientações de Lüdke e André (1986), a análise de conteúdo se finda quando não houver mais documentos para se analisar, ou quando os esforços dedicados às releituras, verificação e validação das informações agregarem ínfimo valor à investigação. De acordo com as autoras, esse é um indício de que a análise de conteúdo pode ser concluída.

Assim, exposto o embasamento metodológico de nossa pesquisa, passamos no próximo capítulo à apresentação da análise e discussão dos resultados. 


\section{ANÁLISE E DISCUSSÃO DOS RESULTADOS}

Neste capítulo, apresentamos a discussão dos resultados que, conforme já mencionado, teve a análise organizada em três eixos, que se desdobram em 11 categorias e três subcategorias. O primeiro eixo é composto de uma caracterização dos processos seletivos, enfatizando os editais e Ifes e, com isso, situando o leitor sobre a oferta de cursos de Letras Libras e Pedagogia bilíngue na última década. Por sua vez, o segundo eixo se dedica a discutir as condições de acessibilidade dos candidatos surdos aos mencionados cursos de graduação, cabendo ao terceiro eixo a atenção para a disposição de vagas entre os candidatos, de onde será possível vislumbrar questões como, por exemplo, a garantia de prioridade dos surdos e o cruzamento desta com a PAA.

\subsection{CARACTERIZAÇÃO DOS PROCESSOS SELETIVOS}

O primeiro eixo de análise desta pesquisa foi constituído de três categorias e uma subcategoria. Um enfoque mais descritivo é dado neste momento, quando nos guiamos mais pela análise longitudinal do cenário da oferta de cursos, o perfil dos editais e os requisitos para o ingresso nos cursos de graduação para formação de professores de Libras nas Ifes, durante o período de 2006 a maio de 2015. Importa salientar que o principal intuito com este eixo foi traçar uma caracterização dos processos seletivos aqui investigados e, sempre que possível, acenar tendências com base na última década. Por essa razão, inicialmente, será dado um enfoque menor para o acesso do surdo, para em seu lugar propor um desenho da organização dos processos seletivos promovidos pelas Ifes.

\subsubsection{O panorama da oferta de cursos de Letras Libras e Pedagogia bilíngue de 2006 a 2015}

Consideramos válido tecer considerações sobre a leitura longitudinal (BAUER, 2002) de nossos registros, ou seja, dos dados construídos por intermédio de nosso corpus e que podem ser úteis para se obter um panorama mais amplo da situação dos cursos de graduação para formação de professores de Libras no país ao longo dos últimos anos. 
No período entre 2006 a maio de 2015, encontramos 25 Ifes que ofertaram mais de 4.315 vagas para formação de professores de Libras ${ }^{77}$. As instituições com maior tradição e volume nesse âmbito são o Ines com 11 processos seletivos, a UFPB e a UFG com sete processos seletivos, a Ufsc com seis e a UFPA com cinco. O quantitativo de editais produzidos pelas Ifes nesse âmbito está expresso com maior clareza no Gráfico 5.1.

Gráfico 5.1 - Editais de processos seletivos para formação de professores de Libras localizados entre 2006 a 2015

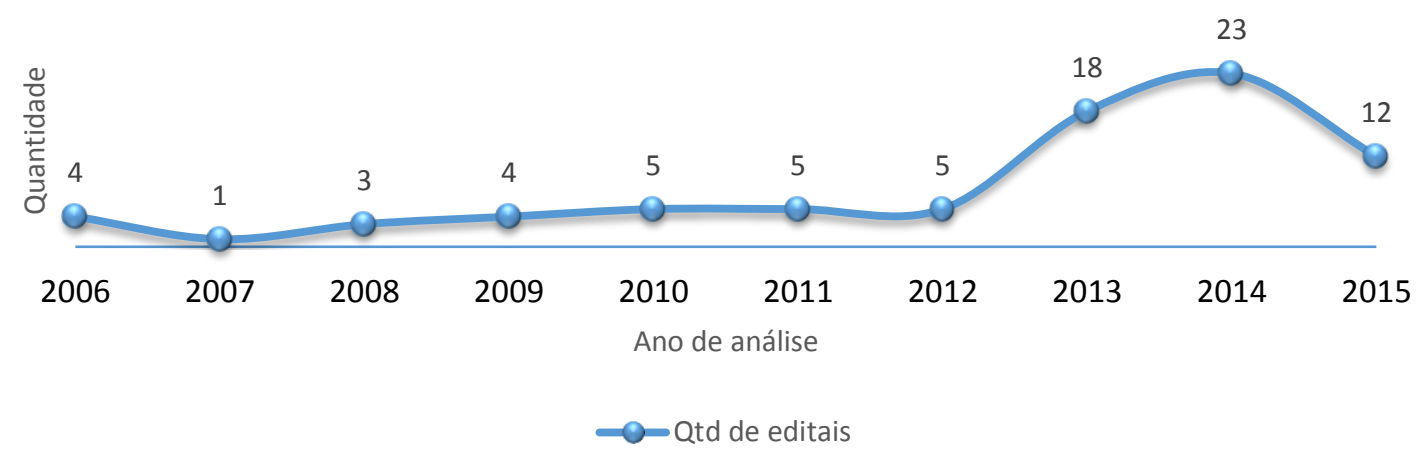

Como pode ser observado pelo Gráfico 5.1, entre os anos de 2006 a 2012 houve uma média de quatro editais por ano, sendo representados por cinco instituições, a saber: o Ines (2006-1, 2006-1, 2006-2, 2007-2, 2008-2, 2009-2, 2010-2, 2011-2, 2012-2), a Ufsc (2006-2, 2008-1, 2009-1, 2010-1, 2011-2, 2012-2, 2012-2), a UFG (2008-2, 2009-2, 2010-2, 2011-2, 2012-2), a UFPB (2009-2, 2010-1, 2011-2) e a UFPA (2010-2, 2011-2, 2012-2), sendo importante pontuar que em 2006, 2012, 2013 e 2014 algumas instituições divulgaram mais de um edital por ano, pois conforme apresentado no capítulo metodológico, nossa análise proveio de 80 editais advindos de 73 processos seletivos. Logo, ocorreu de, em um mesmo processo seletivo, haver a divisão das vagas em mais de um edital ou de uma mesma Ifes abrir mais de um processo seletivo no ano.

Contudo, a partir de 2013 e até 2015 é possível notar significativa expansão na oferta de editais, sendo 18 editais em 2013, 23 em 2014 e 12 até maio de 2015, isto resulta em uma média de 17 editais por ano, o quádruplo do quantitativo vislumbrado nos anos subsequentes à publicação do Decreto n ${ }^{\circ}$ 5.626/05 (BRASIL, 2005). Considerando ainda que o ano de 2015 não foi coberto integralmente em nossa análise, é possível inferir que tenha superado o anterior. Evidentemente, o aumento dos editais de processos seletivos está interligado ao acréscimo no

\footnotetext{
${ }^{77}$ Registramos a expressão "mais de 4.315 vagas", pois dois editais publicados pela UFRJ no ano de 2013 não apresentaram o número de vagas ofertadas. Como também não houve um consenso entre o número de vagas ofertadas nos anos seguintes, variando de 30 a 50, torna-se impossível confirmar a quantidade de vagas de 2013.
} 
número de Ifes que ofertaram cursos e, portanto, divulgaram editais, conforme o Gráfico 5.2 ilustra:

Gráfico 5.2 - Ifes que ofertaram cursos para formação de professores de Libras entre 2006 a 2015

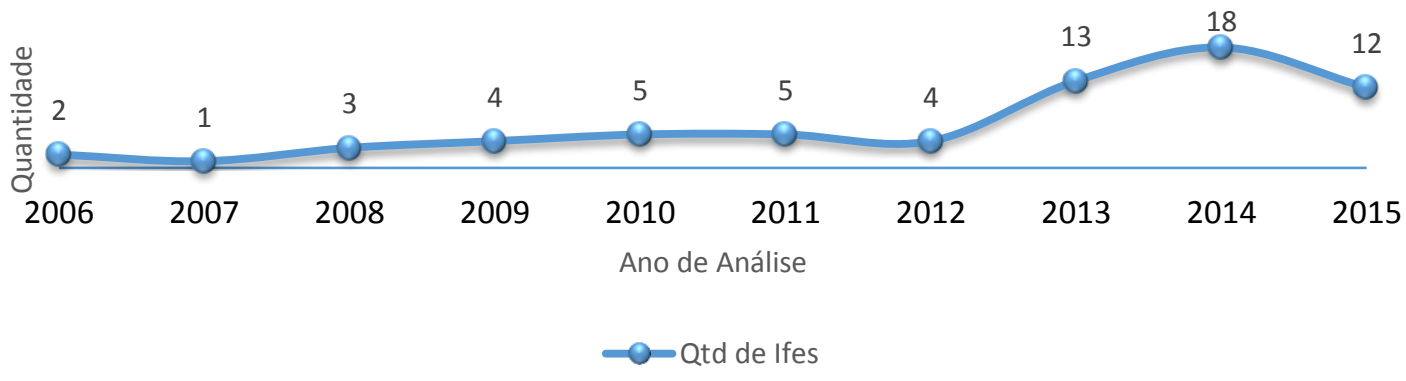

Em 2006, um ano após a formalização do perfil de cursos de graduação para formação de professores de Libras ter sido deliberada (BRASIL, 2005), apenas duas Ifes se lançaram nessa empreitada, quando, em 2014, já podem ser constatadas 18 Ifes, sendo que, em uma Ifes (URFJ) foram divulgados três editais de processo seletivo nesse mesmo ano, em outras três Ifes (Ufsc, Ufam e UFS) três editais e nas outras 14 Ifes (UFPR, IFG, UFJF, UFMT, UFPA, Unifap, UFMA, UFC, Ufersa, UFRN, UFPE, UFPB, Ufal e Ines) apenas um. Nota-se, que esse crescimento não ocorreu gradativamente ao longo dos anos, mas houve uma curva acentuada, sobretudo a partir de 2012.

Em nossa visão, parte desse avanço pode ser atribuído ao Plano Nacional dos Diretos da Pessoa com Deficiência - Programa Viver sem Limite (doravante Programa Viver sem Limite), oficializado por intermédio do Decreto $\mathrm{n}^{\circ}$ 7.612, de 17 de novembro de 2011 (BRASIL, 2013b), que propôs como uma de suas metas para o período entre 2011 e 2014 a ampliação da educação bilíngue no país por meio da criação de 27 cursos de Letras Libras (licenciatura e bacharelado) e 12 cursos de Pedagogia na perspectiva bilíngue. Assim, embora a expansão de Ifes seja observada somente a partir de 2012, acreditamos que o crescimento dentro do período de metas do Programa Viver sem Limite não pode ser ignorado. Em nossa visão, o referido programa resulta da determinação legal do artigo 11 do Decreto $n^{\circ}$ 5.626/05:

Art. 11. O Ministério da Educação promoverá, a partir da publicação deste Decreto, programas específicos para a criação de cursos de graduação:

I - para formação de professores surdos e ouvintes, para a educação infantil e anos iniciais do ensino fundamental, que viabilize a educação bilíngue: Libras - Língua Portuguesa como segunda língua;

II - de licenciatura em Letras: Libras ou em Letras: Libras/Língua Portuguesa, como segunda língua para surdos; (BRASIL, 2005, p. 28, grifo nosso). 
Ademais, para ilustrar nossas suspeitas da influência do referido programa governamental na expansão das ofertas de cursos a partir de 2013, cabe salientar que este é citado por Quadros e Stumpf (2014) como ligado ao curso de Letras Libras da Ufsc ${ }^{78}$ e mencionado no edital de 2014 da UFPE, conforme se observa no Excerto 1:

\section{Excerto 1}

1.1. O Processo Seletivo Simplificado para preenchimento de 30 vagas no Curso de LETRAS LINGUA BRASILEIRA DE SINAIS - LIBRAS: LICENCIATURA, no segundo semestre de 2014 obedece ao Plano Nacional dos Direitos da Pessoa com Deficiência - Programa Viver sem Limite, Decreto $\mathrm{n}^{\circ}$ 7.612, de 17 de novembro de 2011, que prioriza o acesso das pessoas com deficiência a educação básica e superior e satisfará às diretrizes deste Edital. (UFPE, 2014-2 [ingresso 2014-2 Presencial], p. 1 , grifo nosso) ${ }^{79}$

Com efeito, damos crédito ao Programa Viver sem Limite, pois confiamos no poder que a influência de medidas políticas pode causar na realidade educacional. Um exemplo disso é citado por Quadros e Stumpf (2014) quando observam que, conforme dados do Instituto Brasileiro de Geografia e Estatística (IBGE) do ano de 2000, somente 0,94\% dos surdos ingressavam na educação superior. As autoras informam que, em 2002, foram contabilizados 344 alunos surdos nessa etapa da educação, ao passo que em 2005 havia 2.428, ou seja, um aumento de $705 \%$. A que se deve esse crescimento? Quadros e Stumpf (2014) deduzem que esse fato está atrelado ao reconhecimento da Libras alcançado pela Lei n ${ }^{\circ}$ 10.436/02 (BRASIL, 2002). Assim, em nossa concepção, isto pode ser entendido na relação entre o aumento de Ifes que promovem a oferta dos cursos de formação para docência em Libras e a implementação do Programa Viver sem Limite, ou seja, acreditamos que tal crescimento foi alcançado em virtude da implementação e mudança no cenário das políticas públicas voltadas à educação de surdos.

No entanto, embora se perceba a expansão desses editais e de Ifes, ao confrontar os Gráficos 5.1 e 5.2 à meta do Programa Viver sem Limite, conferimos que, apesar do empenho e contribuições, o resultado ainda ficou inferior ao da proposta inicial. Isso porque entre as 18 Ifes de 2014 seria necessário subtrair as quatro Ifes cujos cursos foram criados anteriormente a data do referido plano. Logo, apenas 14 Ifes seriam elegíveis como resultado do período do

\footnotetext{
${ }^{78}$ De acordo com Albres (2014), a partir do ano de 2013, a Ufsc implementou a oferta regular bienal do curso de Letras Libras, na modalidade EaD, em parceria com a Universidade Aberta do Brasil e com financiamento do Programa Viver sem Limite (BRASIL, 2013b). As primeiras instituições contempladas nessa nova estrutura foram a própria Ufsc, a UFMA e o Instituto Federal Farroupilha do Rio Grande do Sul.

${ }^{79}$ Estamos utilizando como convenção registrar a referência de cada edital indicando a sigla da Ifes, seguida do ano de divulgação do edital acompanhada da ordem do semestre e entre colchetes grafamos o ano e o semestre de ingresso ao qual se refere o processo seletivo e a modalidade na qual o curso está inscrito.
} 
Programa Viver sem Limite, sendo uma para atender a promessa de 12 cursos de Pedagogia bilíngue e 13 para atender a meta de 27 cursos de Letras Libras. Convém ressaltar ainda que, dentre os 27 cursos de Letras Libras, podem estar incluídos os cursos de bacharelado não computados na presente pesquisa por não integrarem nosso recorte.

Em síntese, notamos que o segmento mais fragilizado recaiu na formação de professores de Libras para a educação infantil e nos anos iniciais do ensino fundamental, que devem ser formados, conforme determina o Decreto $\mathrm{n}^{\circ}$ 5.626/05 (BRASIL, 2005), em cursos bilíngues de Pedagogia. Suspeita confirmada quando consultamos o sítio eletrônico do observatório do Programa Viver sem Limite (BRASIL, 2016b) em que constam apenas informações pertinentes à criação dos cursos de Letras Libras, sem nenhuma indicação à meta dos cursos de Pedagogia bilíngue. Analisado o número de vagas ofertadas para acesso aos cursos de Pedagogia bilíngue na última década, encontramos 639 vagas, ao passo que para o curso de Letras Libras foram oferecidas 3.676 vagas. Neste viés, cabe questionar: como respeitaremos a surdez como diferença e garantiremos a educação bilíngue às crianças surdas sem a presença de profissionais formados para atuar na docência da Libras em seus primeiros anos de escolaridade? Continuaremos reproduzindo práticas e programas de bilinguismo subtrativo (HAMEL, 1989; MAHER, 2007) no qual os professores com pouco ou nenhum domínio em Libras sobrevalorizam a Língua Portuguesa?

Em concordância com Lacerda, Albres e Drago (2013), percebemos que a quantidade de vagas para cursos de graduação para formação de professores de Libras, ofertados ao longo dos últimos anos, tal como representado no Gráfico 5.3, desnuda a insuficiência de profissionais formados para atender a demanda nacional.

Gráfico 5.3 - Quantidade de vagas ofertadas para formação de professores de Libras entre 2006 a 2015

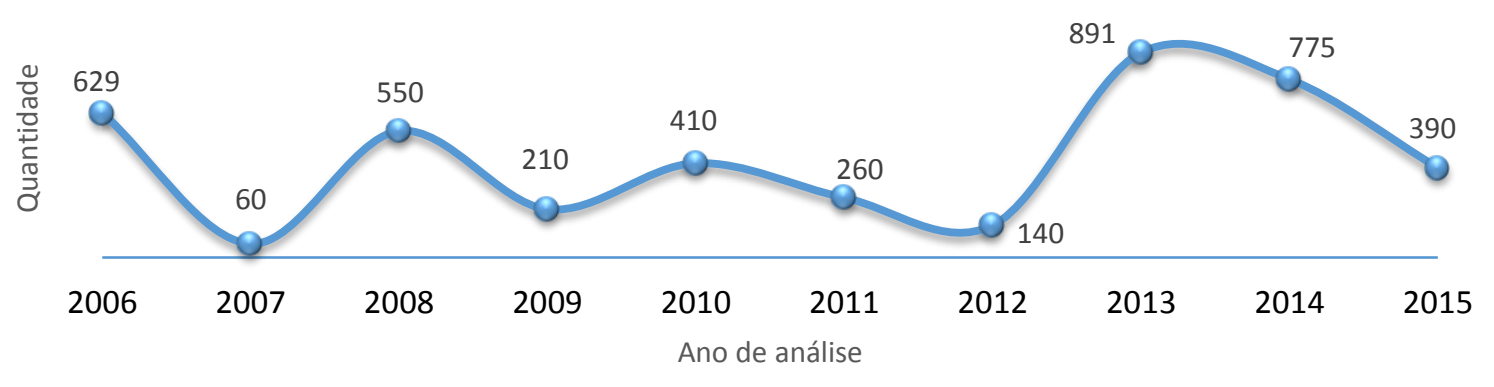


Chama-nos a atenção ainda, como mostram as linhas do Gráfico 5.3, concernente à oferta de número de vagas para formação de professores de Libras na educação superior, que os valores nem sempre dependem do número de Ifes ou de editais de processos seletivos. Em 2007, quando localizamos apenas o edital do Ines para o curso de Pedagogia bilíngue, temos o ponto mais baixo do gráfico, com uma oferta de 60 vagas no referido ano. Entretanto, a análise do ano de 2014 não corresponde a essas expectativas, pois, embora esse tenha sido o ano com mais Ifes e mais editais (conforme Gráficos 5.1 e 5.2), no Gráfico 5.3 percebemos não ter sido o ano com maior número de vagas disponíveis, e sim o ano de 2013, em que houve 891 vagas ofertadas por meio de 18 editais divulgados por 13 Ifes (Ufsc, 2013-2; UFGD, 2013-1; UFRJ, 2013-2, 2013-2; UFJF, 2013-2, 2013-2; UFU, 2013-2, 2013-2, 2013-2; Ufac, 2013-2; UFG, 2013-2; UFPA, 2013-2; UFC, 2013-1; Ufersa, 2013-2; UFRN, 2013-1; UFPB, 2013-1, 20132; Ines, 2013-2). Aliás, confirmamos a teoria de que a quantidade de vagas independe do número de Ifes e de editais se considerarmos que, em 2006, quando havia apenas duas Ifes e quatro editais, divulgaram-se 629 vagas, ao passo que, em 2014, foram ofertadas 775 vagas por 18 Ifes em 23 editais.

Isso ocorre, pois, a análise dessa desproporção entre o número de vagas ofertadas por ano e o montante de Ifes e editais deve considerar a modalidade dos cursos de formação de professores de Libras, ou seja, se são presenciais ou EaD, conforme pode ser conferido no Gráfico 5.4:

Gráfico 5.4 - Quantidade de vagas ofertadas nas modalidades EaD e presencial para formação de professores de Libras entre 2006 a 2015

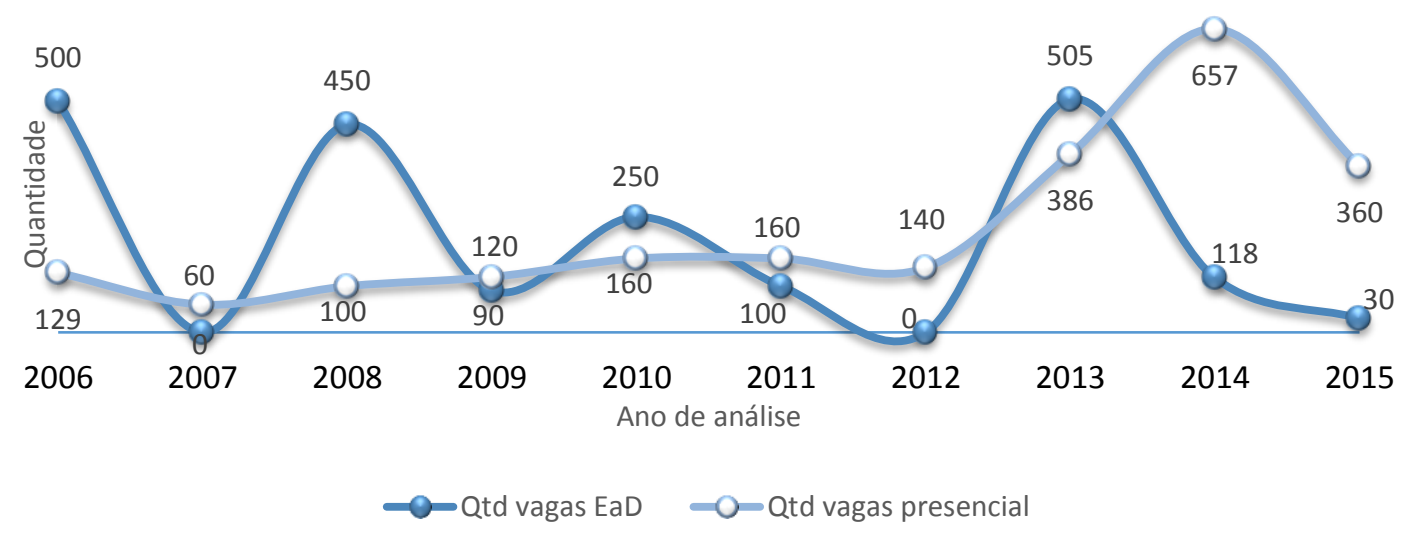

É válido lembrar que, como descrito durante o capítulo metodológico, dentre as 25 Ifes analisadas, as três que se dedicam à EaD são a UFGD, a UFPB e a Ufsc. Mas, esta última oferta cursos na modalidade presencial e EaD, sendo, portanto, contabilizada em ambas as modalidades. Assim, a Ufsc representa a única Ifes dedicada a ofertar cursos de graduação de 
formação de professores de Libras em ambas as modalidades e iniciou sua trajetória no segmento dentro da $\mathrm{EaD}$, em 2006, sendo, posteriormente, em 2009, divulgado seu primeiro edital de Letras Libras na modalidade presencial. Nota-se, portanto, que, ao longo dessa última década, a maioria das Ifes não levou a experiência da modalidade presencial para a EaD e viceversa. Ademais, embora haja apenas três Ifes dedicadas à $\mathrm{EaD}$ e 23 Ifes à modalidade presencial, nesse período, o percentual das vagas ofertadas ao longo dos anos, por modalidade de ensino, é bastante semelhante, como exibido no Gráfico 5.5:

Gráfico 5.5 - Percentual de vagas ofertadas nas modalidades EaD e presencial para formação de professores de Libras entre 2006 a 2015

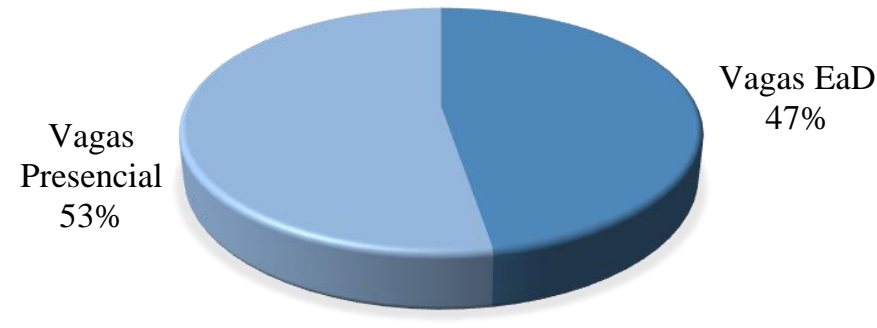

Os cursos de graduação a distância de três Ifes (Ufsc, UFGD e UFPB) ofertaram 2.043 vagas, que corresponde a 47\%, enquanto os cursos presenciais geridos por 24 Ifes (UFPR, UFRJ, UFJF, UFU, UFG, Ufsc, IFG, UFMT, UFT, Ufac, Ufam, UFPA, Unifap, UFMA, UFPI, UFC, Ufersa, UFRN, UFPE, Ufal, UFS, Ufra, Ines) somam 2.272 vagas, equivalente a 53\% do total de vagas desse período. Logo, é possível asseverar que a EaD foi uma grande aliada na expansão da oferta de vagas para formação de professores de Libras.

A esse respeito, Cerny e Vilhalva (2014), ao narrarem sobre a experiência da gestão pedagógica do curso de Letras Libras da Ufsc na modalidade EaD, declaram como:

É importante registrar que o uso da tecnologia na formação de surdos tem auxiliado o seu desenvolvimento, pois a necessidade de traduzir os conteúdos para Libras, uma vez que a Libras é a língua de instrução deste curso, tornase viável com o uso da tecnologia, e favorece que um número maior de estudantes tenha acesso aos conteúdos. (CERNY; VILHALVA, 2014, p. 53).

De acordo com Quadros e Stumpf (2014), o referido curso de graduação a distância, apesar de pioneiro foi reconhecido pelo MEC e obteve nota $\operatorname{cinco}^{80}$. As autoras consideram que

\footnotetext{
${ }^{80}$ As autoras não indicam o ano do reconhecimento ou da avaliação do MEC feita ao curso. Como já foi dito anteriormente, sabe-se que, em conformidade ao Decreto $\mathrm{n}^{\circ} 5.773 / 06$, o credenciamento das faculdades pode ocorrer em um prazo máximo de três anos. Ademais, durante nosso levantamento de IES realizado no sítio
} 
com o recurso da tecnologia aliada à modalidade da $\mathrm{EaD}$, sem perder em excelência, a Ufsc conseguiu promover a descentralização da formação de profissionais para a docência da Libras, ao viabilizar o curso para diferentes estados brasileiros e, com isso, atender um número maior de alunos e localidades (QUADROS; STUMPF, 2014).

Com efeito, a Ufsc correspondeu à instituição com maior oferta de vagas para cursos de graduação em Letras Libras no período analisado, ao todo foram 1.160 vagas, sendo 1.040 para cursos EaD e outras 120 para os cursos presenciais. A UFPB também se sobressaiu como a segunda Ifes nesse ranking, com 923 vagas, todas na modalidade $\mathrm{EaD}$, distribuídas entre os estados da Paraíba e Bahia. Observa-se, portanto, que estas duas Ifes juntas, somam 2.083 vagas um montante referente a quase metade da oferta no período de 2006 a 2015 . Uma amostra dessa distribuição de vagas pode ser acompanhada no Gráfico 5.6.

Gráfico 5.6 - Total de vagas ofertadas em cursos de graduação para formação de professores de Libras entre 2006 a 2015

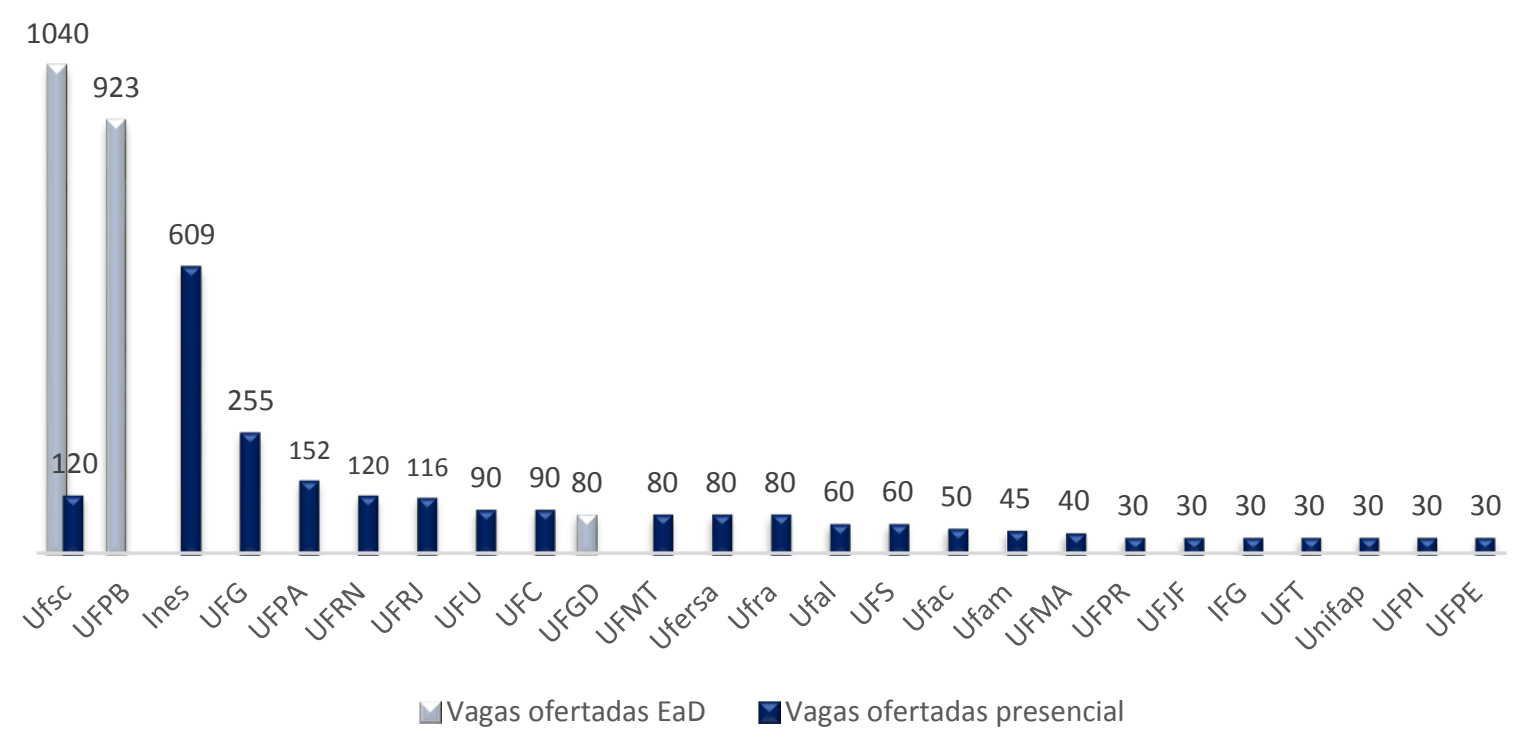

No entanto, esse quantitativo não pode ser olhado isoladamente, se faz necessário considerar que muitas vagas ofertadas não foram integralmente preenchidas, como veremos adiante na seção 5.3.1.1. Além disso, convém ponderar que muitos alunos ingressantes podem não ter concluído o curso, pois embora esse dado não tenha sido captado pela nossa pesquisa, conforme informações cedidas via mensagem eletrônica ${ }^{81}$ pela Divisão de Registro Acadêmico do Ines, até a data de julho de 2014, no curso de Pedagogia bilíngue do Ines, muitos estudantes

eletrônico do e-MEC identificamos que a data de início do funcionamento do curso de Letras Libras na modalidade EaD ocorreu em 27 de outubro de 2006.

${ }^{81}$ DIVISÃO DE REGISTRO ACADÊMICO DIRA. Dados - DESU/Ines. [mensagem pessoal]. Mensagem recebida por <dira.coada@gmail.com>em 7 jul. 2014. 
trancaram a matrícula ou se desligaram durante o referido curso, como representado na Tabela 5.1 .

Tabela 5.1 - Dados quantitativos de alunos do curso bilíngue de Pedagogia do Ines - 2006-2014

\begin{tabular}{ccccc}
\hline & Alunos egressos & Alunos em curso & $\begin{array}{c}\text { Alunos que } \\
\text { trancaram a } \\
\text { matrícula }\end{array}$ & $\begin{array}{c}\text { Alunos } \\
\text { desligados }\end{array}$ \\
\hline Surdos & 21 & 85 & 16 & 52 \\
Ouvintes & 69 & 174 & 21 & 74 \\
Total & 90 & 259 & 37 & 126 \\
\hline
\end{tabular}

Fonte: Divisão de Registro Acadêmico do Ines, 2014 (mensagem eletrônica).

No caso do Ines, curso que teve sua primeira oferta em 2006, como ilustramos na referida Tabela 5.1, e verificamos que, até 2014, ou seja, após 8 anos de oferta do curso bilíngue de Pedagogia, havia somente 90 alunos egressos, sendo 21 surdos e 69 ouvintes, ao passo que 37 alunos trancaram sua matrícula e 126 se desligaram do curso. Apesar de essa conferência não ter sido estendida a todas as Ifes, em virtude da dificuldade de acesso a esses dados ${ }^{83}$, o alerta que esses números provocam indica que o número de vagas ofertadas ou de alunos ingressantes, talvez, não esteja diretamente associado ao número de egressos desses cursos. Isso pode ser ainda mais preocupante se relembrarmos que, no país, o segmento do ensino da Libras na educação infantil e anos iniciais do ensino fundamental, até a presente data, só conta com esses 90 profissionais egressos do Ines, uma vez que o curso de Pedagogia bilíngue do IFG foi inaugurado no ano de 2015.

Devido à falta de investimento na graduação de professores de Libras, os alunos surdos ficam desassistidos de profissionais qualificados para assegurarem sua educação bilíngue, sendo submetidos a docentes que, conforme Gesser (2012), atuam com base em suas próprias experiências didáticas, construídas especialmente dentro de modelos mecanicistas e com uma alta probabilidade de insucesso. Alimentamos com isso, o círculo vicioso (FAVORITO, 2006) do fracasso escolar de alunos surdos que sem desenvolverem plenamente suas competências linguísticas na L1 podem, por conseguinte, enfrentar dificuldades no domínio da L2.

Depois de deslindarmos sobre os processos seletivos, quantitativos de vagas, modalidades e Ifes que compuseram o cenário da oferta de vagas para formação de professores

\footnotetext{
${ }^{82}$ Consideramos relevante inserir também os dados dos alunos desligados e os que trancaram a matrícula, visto permitirem observar o número expressivo de estudantes que ingressaram no curso, mas sem concluírem. Sendo que, até 2014, esse era o único curso bilíngue de Pedagogia do país, e com base no baixo índice de egressos desse curso, é possível inferir que não há profissionais suficientes, em tal segmento, para atender a demanda da educação bilíngue para surdos.

${ }^{83}$ Buscamos, via endereço eletrônico, contato com o MEC, com o Programa Viver sem Limite e com outras duas Ifes, além do Ines, a saber: a Ufsc e a UFPB. Obtivemos retorno apenas do Ines.
} 
de Libras na educação superior, o próximo item abrangerá a organização da forma de ingresso escolhida pelas Ifes durante os processos seletivos.

\subsubsection{Organização da forma de ingresso adotada para os cursos de Letras Libras e Pedagogia bilíngue entre 2006 a 2015}

Dentre os 80 editais analisados, 45 provieram de processos seletivos específicos, ou seja, organizados exclusivamente para os cursos de formação em Libras, enquanto 35 optaram pela chamada geral, na qual os cursos de Letras Libras ou Pedagogia bilíngue foram divulgados em editais em que também constavam informações acerca do vestibular de outros cursos da instituição. Provavelmente, a escolha da maioria por processos seletivos específicos advenha de uma dificuldade de elaborar um processo seletivo geral (para vários cursos) e, concomitantemente, atender as singularidades reservadas aos candidatos surdos. Em nossa concepção, todos os editais deveriam prever as condições de acessibilidade aos surdos e, complementarmente, aqueles voltados para ingresso em cursos de formação de professores de Libras teriam ainda o compromisso de garantir a prioridade a estes. Apesar disso, a análise dos editais nos mostrou que dos 35 documentos que optaram pela chamada geral, 25 deles não fizeram qualquer referência à prioridade dos candidatos surdos, no entanto, dentre os 45 editais específicos apenas em nove documentos não se adotou o critério de prioridade, isto reforça nossa teoria de que, em editais específicos, aparentemente, seria mais fácil para as Ifes atenderem aos critérios previstos em lei para os candidatos surdos.

A escolha por uma chamada geral ou específica durante os processos seletivos também pode estar associada a outros fatores como a experiência ou a modalidade de educação do curso. A Ufsc, por exemplo, é a Ifes mais antiga na oferta da graduação em Letras Libras, e referente aos cursos de formação de professores de Libras advindos da modalidade EaD, foram localizados somente editais específicos. Entretanto, no tocante ao ingresso nos cursos de Letras Libras da modalidade presencial, nas duas primeiras edições de 2009 e 2010, foi organizado um edital específico para o curso de Letras Libras, mas nos anos seguintes a referida Ifes passou a incorporar as normas de ingresso desse curso em editais de chamada geral, junto a oferta dos demais cursos. Na mesma direção, a UFPB, de 2009 até o primeiro semestre de 2013, organizava seus editais para ingresso no curso de Letras Libras da modalidade EaD somente em processos seletivos específicos para esse curso. Aparentemente, com maior experiência no segmento a referida Ifes, a partir do segundo semestre de 2009 até 2015, passou a organizar o edital sob o modelo da chamada geral. Em contrapartida, Ifes que começaram com editais de 
chamada geral e, posteriormente, adotaram o edital específico não foi vislumbrado em nossos dados. Com efeito, os cursos de formação de professores de Libras mais recentes buscaram o edital específico, e dentre aqueles que fizeram a escolha pela chamada geral, em mais de $34 \%$ dos casos, os processos seletivos não organizaram as próprias avaliações, recorrendo ao Sisu, ao CR de alunos graduados ou ao sorteio eletrônico como ferramentas de ingresso, modelos que passaremos a discutir.

Um dos aspectos observados em nossa análise dos editais consiste no fato de alguns processos seletivos não terem se responsabilizado pela organização das provas, delegando a aprovação dos candidatos a outras ferramentas de seleção. Nessa direção, foram encontrados dois editais da UFPB, um em 2014 e outro em 2015, direcionados unicamente para candidatos já graduados, cuja seleção foi feita pelo coeficiente de rendimento (CR) escolar baseado em um cálculo das notas das disciplinas cursadas pelos alunos emitidas em seus respectivos históricos acadêmicos.

Não é possível afirmar com clareza se essa medida beneficia os candidatos surdos, pois, em concordância com Daroque e Queiroz (2013), é preciso ponderar que, além das dificuldades existentes em sua trajetória escolar, os poucos surdos que conseguem ingressar na educação superior se deparam com inúmeros obstáculos, entre os quais, a falta de conhecimento por parte dos docentes de como lidar com as condições linguísticas, culturais e curriculares especiais deste estudante e, muitas vezes, a ausência da figura do intérprete de Libras. Logo, as consequências de tais desafios refletem-se em seu desempenho acadêmico, o que tornariam menores suas chances em um processo seletivo como o proposto pela UFPB. Apesar disso, é difícil afirmar com certeza se esse modelo de seleção seria menos injusto com os candidatos surdos, em comparação àqueles em que as provas são organizadas nos parâmetros exclusivos da escola tradicional.

Outros processos seletivos que não realizaram a organização de provas foram desenvolvidos pela UFRJ (2014-1 [ingresso 2014-2 Presencial]) e pela Ufra (2015-1 [ingresso 2015-2]), utilizando de sorteio eletrônico viabilizado por intermédio da Plataforma Paulo Freire, um sistema eletrônico criado pelo MEC e gerenciado pela Capes para promoção de cursos de formação direcionados aos professores da rede pública. Tal processo está alinhado com o Parfor, implementado por intermédio do Decreto $\mathrm{n}^{\circ}$ 6.755, de 29 de janeiro de 2009 (BRASIL, 2009b) em regime de colaboração entre a Capes, os estados e municípios e as IES.

De acordo com a Capes (COORDENAÇÃO DE APERFEIÇOAMENTO DE PESSOAL DE NÍVEL SUPERIOR, 2015), o Parfor tem por finalidade "induzir e fomentar a oferta da educação superior, gratuita e de qualidade, para professores em exercício na rede 
pública da educação básica [...]” atendendo às exigências da LDB/96 (BRASIL, 1996) e promovendo melhoria na qualidade da educação básica. Neste enfoque, professores desprovidos de formação na educação superior ou com formação diferente da sua área de atuação podem se graduar por meio de ingresso nas turmas especiais do Parfor.

Especificamente, o Parfor atua em três linhas:

I. Licenciatura - para docentes ou tradutores intérpretes de Libras em exercício na rede pública da educação básica que não tenham formação superior ou que mesmo tendo essa formação se disponham a realizar curso de licenciatura na etapa/disciplina em que atua em sala de aula;

II. Segunda licenciatura - para professores licenciados que estejam em exercício há pelo menos três anos na rede pública de educação básica e que atuem em área distinta da sua formação inicial, ou para profissionais licenciados que atuam como tradutor intérprete de Libras na rede pública de Educação Básica; e

III. Formação pedagógica - para docentes ou tradutores intérpretes de Libras graduados não licenciados que se encontram no exercício da docência na rede pública da educação básica. (COORDENAÇÃO DE APERFEIÇOAMENTO DE PESSOAL DE NÍVEL SUPERIOR, 2015).

No tocante aos candidatos surdos, o item I desse plano também poderia contemplar os instrutores de Libras, com formação em nível médio, que estivessem porventura atuando na rede pública sem a formação exigida. Embora tanto o número de instrutores como o de docentes surdos na educação básica ainda não seja identificado, é provável que os principais beneficiados do Parfor sejam os profissionais ouvintes, uma vez que, conforme Skliar (2016), em geral, nas escolas, incluindo as bilíngues, a maior parte do quadro de funcionários é composta por ouvintes.

Além disso, cabe mencionar que a UFRJ (2014-1 [ingresso 2014-2 Presencial]) e a Ufra (2015-1 [ingresso 2015-2]) não foram as únicas Ifes que consideraram a formação de professores em exercício nos seus editais. Contudo, diferentemente dessas Ifes que direcionaram $100 \%$ das vagas para professores, encontramos a UFPB que, por intermédio do Plano de Ações Articuladas para a Formação de Professores (PAR), designou parte das vagas para professores da rede pública, sejam eles surdos ou ouvintes, durante os processos seletivos publicados nos anos de 2009, 2010, 2011, 2013-1 e 2013-2. No ano de 2009, como pode ser conferido na Tabela 5.2, bem como em 2013 as vagas foram destinadas entre candidatos surdos, ouvintes e professores da rede pública; mas, em 2010 e 2011 (a relação das vagas de 2011 é apresentada na Tabela 5.3), a oferta se dividiu somente entre candidatos surdos e professores da rede pública (via PAR), sendo aos ouvintes resguardado o direito de pleitearem as vagas remanescentes. 
Tabela 5.2 - Distribuição das vagas do edital da UFPB (2009-2) para o processo seletivo de licenciatura em Letras Libras

\begin{tabular}{|c|c|c|c|c|}
\hline CÓDIGO & CURSO & $\mathbf{U F}$ & POLO & $\begin{array}{c}\text { VAGAS } \\
\text { PERÍODO } \\
2010.1\end{array}$ \\
\hline 30207 & LETRAS/LIBRAS - SURDOS & PB & $\begin{array}{l}\text { CAMPINA } \\
\text { GRANDE }\end{array}$ & 10 \\
\hline 10207 & LETRAS/LIBRAS - OUVINTES & $\mathrm{PB}$ & $\begin{array}{l}\text { CAMPINA } \\
\text { GRANDE }\end{array}$ & 10 \\
\hline 20207 & $\begin{array}{l}\text { LETRAS/LIBRAS - PROFESSORES } \\
\text { DA REDE PÚBLICA }\end{array}$ & $\mathrm{PB}$ & $\begin{array}{l}\text { CAMPINA } \\
\text { GRANDE }\end{array}$ & 10 \\
\hline 31507 & LETRAS/LIBRAS - SURDOS & PB & JOÃO PESSOA & 10 \\
\hline 11507 & LETRAS/LIBRAS - OUVINTES & $\mathrm{PB}$ & JOÃO PESSOA & 10 \\
\hline 21507 & $\begin{array}{l}\text { LETRAS/LIBRAS - PROFESSORES } \\
\text { DA REDE PÚBLICA }\end{array}$ & PB & JOÃO PESSOA & 10 \\
\hline 32307 & LETRAS/LIBRAS - SURDOS & PB & POMBAL & 10 \\
\hline 12307 & LETRAS/LIBRAS - OUVINTES & PB & POMBAL & 10 \\
\hline 22307 & $\begin{array}{l}\text { LETRAS/LIBRAS - PROFESSORES } \\
\text { DA REDE PÚBLICA }\end{array}$ & $\mathrm{PB}$ & POMBAL & 10 \\
\hline
\end{tabular}

Fonte: Universidade Federal da Paraíba (2009-2 [ingresso 2010-1 EaD], p. 2).

Tabela 5.3 - Distribuição das vagas do edital da UFPB (2011-2) para o processo seletivo de licenciatura em Letras Libras

\begin{tabular}{|c|c|c|c|c|}
\hline CÓDIGO & CURSO & POLO & UF & $\begin{array}{c}\text { VAGAS } \\
\text { PERÍODO } \\
\text { 2012.1 }\end{array}$ \\
\hline 42707 & LETRAS/LIBRAS - PAR & ALAGOA GRANDE & PB & 13 \\
\hline 32707 & LETRAS/LIBRAS - SURDOS & ALAGOA GRANDE & PB & 12 \\
\hline 40207 & LETRAS/LIBRAS - PAR & CABECEIRAS & PB & 13 \\
\hline 30207 & LETRAS/LIBRAS - SURDOS & CABECEIRAS & PB & 12 \\
\hline 40407 & LETRAS/LIBRAS - PAR & CAMPINA GRANDE & $\mathrm{PB}$ & 13 \\
\hline 30407 & LETRAS/LIBRAS - SURDOS & CAMPINA GRANDE & $\mathrm{PB}$ & 12 \\
\hline 42307 & LETRAS/LIBRAS - PAR & POMBAL & $\mathrm{PB}$ & 13 \\
\hline 32307 & LETRAS/LIBRAS - SURDOS & POMBAL & $\mathrm{PB}$ & 12 \\
\hline
\end{tabular}

Fonte: Universidade Federal da Paraíba (2011-2 [ingresso 2012-1 EaD], p. 3).

Dentre as Ifes investigadas nesta pesquisa, somente a UFPB aderiu ao PAR no que se refere à promoção da formação de professores em serviço para a graduação em Letras Libras. O PAR, semelhantemente ao Parfor, é subsidiado técnica e financeiramente pela União, mas no caso do PAR está relacionado ao Plano de Metas Compromisso Todos pela Educação, apoiado pelo MEC e disposto no Decreto ${ }^{0}$ 6.094, de 24 de abril de 2007 (BRASIL, 2007a). Portanto, após a adesão de estados e municípios, estes desenvolvem um diagnóstico da realidade educacional no qual se inserem e, em seguida, constroem o PAR, no qual entre os eixos de ação constam a formação de professores e profissionais de serviços e o apoio escolar (BRASIL, 2007a). Para ter a inscrição aceita como candidato ao curso de Letras Libras, em 2009, a UFPB exigiu aos professores a apresentação do contracheque como comprovação do vínculo funcional de professor com a rede pública estadual ou municipal de ensino, enquanto nos anos ulteriores as inscrições seriam deferidas aos professores cadastrados no PAR. 
Outra tendência evidenciada na análise dos editais de nosso corpus foi de que, a partir de 2008, identificamos 31 processos seletivos que realizaram aproveitamento parcial ou integral da nota do Enem, sendo 15 editais com aproveitamento integral e 16 de aproveitamento parcial. Entendemos como aproveitamento parcial os processos seletivos que, tal como no Excerto 2, dividiram-se em duas fases, na qual a primeira consistiu a nota do Enem e a segunda em uma prova objetiva organizada pela Ifes; ou no Excerto 3 no qual o candidato poderia considerar a nota do Enem no cálculo final da nota da prova; ou ainda como no Excerto 4 em que foi adotado critério diferente de seleção, sendo aos surdos proposta uma prova objetiva desenvolvida pela Ifes e no caso de vagas remanescentes, convocados os candidatos inscritos via Sisu.

\section{Excerto 2 \\ 1 DO PROCESSO SELETIVO \\ 1.1 O Processo Seletivo da Universidade Federal do Pará do ano de 2011- PS/UFPA 2011 será realizado em 2 (duas) Fases. \\ $1.2 \mathrm{~A}^{\mathrm{a}}$ (primeira) Fase corresponde à participação do(a) candidato(a) no Exame Nacional do Ensino Médio no exercício de 2010 (ENEM 2010), de acordo com a Portaria no 807 de 18 de junho de 2010, e pelo Edital No 01/2010 - Inep, de 18 de junho de 2010, que dispõe sobre as diretrizes, procedimentos e prazos da edição do Exame ano 2010. \\ 1.3 A $2^{\text {a }}$. (segunda) Fase do Processo Seletivo consistirá em uma Prova Objetiva composta de 55 (cinquenta e cinco) questões de múltipla escolha que será aplicada pelo Centro de Processos Seletivos (CEPS/UFPA), no dia 19 de dezembro de 2010 (domingo). (UFPA, 2010-2 [ingresso 2011-1 Presencial] p. 1)}

\section{Excerto 3}

7.3 - Para o candidato que optar pelo uso da Nota do Enem (NE), a Nota Final do Vestibular Ufsc/2015 será calculada pela fórmula abaixo e será expressa com duas casas decimais após a vírgula, com arredondamento na segunda casa decimal.

$$
\text { Nota Final }=\left(7 \times \mathrm{xV}^{84}+3 \mathrm{x} \mathrm{NE}\right) / 10
$$

(UFSC, 2014-2 [ingresso 2015-1 Presencial] p. 11).

\section{Excerto 4}

Caso não haja demanda para preenchimento das vagas destinadas aos candidatos surdos no curso de Letras: Libras, estas poderão ser remanejadas e preenchidas por candidatos que optaram pelo curso de Letras: Libras pelo Sisu. (UFG, 2015-1 [ingresso 2015-1 Presencial], p. 6).

Convém mencionar que, no processo seletivo referente ao Excerto 4, apenas $20 \%$ das vagas foram preenchidas pelos surdos que realizaram a prova organizada pela Ifes, as restantes foram preenchidas por candidatos (evidentemente em sua maioria ou totalidade ouvintes) inscritos via Sisu.

\footnotetext{
${ }^{84} \mathrm{NV}=$ Nota do Vestibular.
} 
O aproveitamento integral da nota do Enem como parâmetro de seleção dos candidatos aos cursos de graduação para formação de professores de Libras aqui investigados foi verificado somente após o ano de 2013, apesar do Sisu ter sido implementado em outras universidades em 2010. Em 2013, foram encontradas oito Ifes que fizeram uso exclusivo das notas do Enem, via Sisu, para seleção de seus candidatos, dentre elas a UFPB, cuja redação pode ser observada no Excerto 5:

\section{Excerto 5}

A classificação dos candidatos será efetuada de acordo com as notas obtidas nas provas do Enem de 2013. (UFPB, 2013-2 [ingresso 2014-1 e 2014-2 EaD], p. 9).

O Sisu corresponde a um sistema informatizado desenvolvido pelo MEC, por meio do qual algumas instituições públicas de educação superior ofertam vagas de seus cursos de graduação aos participantes do Enem. Os candidatos interessados devem, obrigatoriamente, ter participado do Enem, pois a nota obtida nesse exame será contabilizada para critérios de seleção. Algumas instituições podem reservar vagas ou atribuir um bônus para determinados grupos, sobretudo aqueles que integram a PAA por serem alunos de escola pública, terem baixa renda familiar comprovada e/ou serem autodeclarados "pretos, pardos ou indígenas". Além disso, outros critérios podem ser adotados, tal como a sobrevalorização de notas do Enem em determinadas áreas do conhecimento (conforme o curso escolhido), nota de corte etc. (BRASIL, 2016c).

De acordo com Silveira, Barbosa e Silva (2015), apesar do Enem ter sido criado em 1998, por mais de dez anos foi utilizado exclusivamente para a avaliação das habilidades e competências de concluintes do ensino médio. Para tais autores, ainda existem várias críticas referentes à formulação das questões do Enem, posto que esse instrumento de avaliação ainda carece de aperfeiçoamento, especialmente ao se propor utilizá-lo como ferramenta de seleção de candidatos a cursos de graduação das Ifes. Sem focalizar nas questões da prova para candidatos surdos, os autores esclarecem:

[...] uma análise detalhada nas últimas edições do Enem sobre as questões de física tem apontado sérios problemas em diversas delas. Os problemas variam desde a formulação de questões que já no seu comando apresentam um enunciado em contradição com o conhecimento físico (portanto impossíveis de serem respondidas por quem domine o tema), até questões que não apresentam resposta correta ou que apresentam mais de uma alternativa correta. (SILVEIRA; BARBOSA; SILVA, 2015, p. 1.101-5). 
Neste aspecto, se a formulação da prova apresenta falhas que podem ser prejudiciais ao desempenho de candidatos ouvintes, isso, certamente, afetaria também os candidatos surdos que, conforme Daroque e Queiroz (2013), já enfrentam desafios anteriores ao Enem em seu processo de escolarização e acesso aos conhecimentos curriculares, pois como discutido anteriormente, em muitos casos, eles podem ter sido expostos a uma educação pautada na reabilitação da deficiência que privilegiava a terapia da fala à escolarização.

Em face dessa problemática, Pereira (2016, p. 1) levanta questionamentos como: “Onde estariam os surdos no âmbito do ensino superior? Ou mais precisamente na universidade pública?", uma vez que ao se restringir o acesso via Enem, muitos alunos surdos podem ser prejudicados. A autora não investiga especificamente o ingresso nos cursos de graduação de formação de professores de Libras, mas traz contribuições para nossa discussão por ser um dos poucos estudos localizados a problematizar a realização desse exame e seu aproveitamento no Sisu com os participantes surdos. Pereira (2016), ao analisar as questões do Enem da área de ciências da natureza e suas tecnologias, referente aos anos de 2013, 2014 e 2015, verificou a pouca acessibilidade da prova para os surdos por se pautar fundamentalmente no domínio do conteúdo escrito, explorando poucos recursos visuais que lhes favoreceriam a compreensão. A referida autora também salienta a restrita participação dos intérpretes de Libras que são limitados à tradução de termos, pois têm sido orientados a não traduzirem para a Libras as questões integralmente (PEREIRA, 2016).

Sob esse prisma, a autora acredita ser preciso considerar a formação e/ou orientação dos intérpretes que atuam nesse contexto, uma vez que a influência desses afeta a acessibilidade dos participantes surdos, observando que alguns profissionais são orientados a traduzirem os informes do exame, bem como a prova na íntegra, enquanto outros apenas termos específicos da Língua Portuguesa (PEREIRA, 2016). Diante desse cenário, cabe questionar se esse modelo de seleção via Sisu seria produtivo e justo com os candidatos surdos que não têm sido satisfatoriamente assistidos no Enem. Essa indagação remete à urgência de se avançar com pesquisas acerca desse contexto, analisando as condições de acessibilidade para candidatos surdos ao Enem, a formulação das provas, a correção das provas que devem considerar as especificidades linguísticas do português como L2 para surdos, sua influência no ingresso aos cursos universitários via Sisu etc.

Provavelmente, deva-se a essa complexidade e críticas à aplicação do Enem para candidatos surdos o fato de em 2013 terem sido localizados oito processos seletivos pautados, exclusivamente, pela nota do Enem (sendo dois editais da UFRJ, um da UFU, um da Ufac, um da UFPA, um da UFC, um da Ufersa e outro da UFPB), e nos anos seguintes de 2014 e 2015 
ter ocorrido em cada ano um decréscimo nesses valores para quatro editais, respectivamente correspondentes à Ufam, Ufac, UFC e Ufersa em 2014 e UFU, Ufam, UFC e Ufersa em 2015. Essa quantidade ao longo dos anos pode ser conferida no Gráfico 5.7.

Gráfico 5.7 - Quantidade de editais com seleção baseada na nota do Enem para ingresso em cursos de formação de professores de Libras entre 2006 a 2015

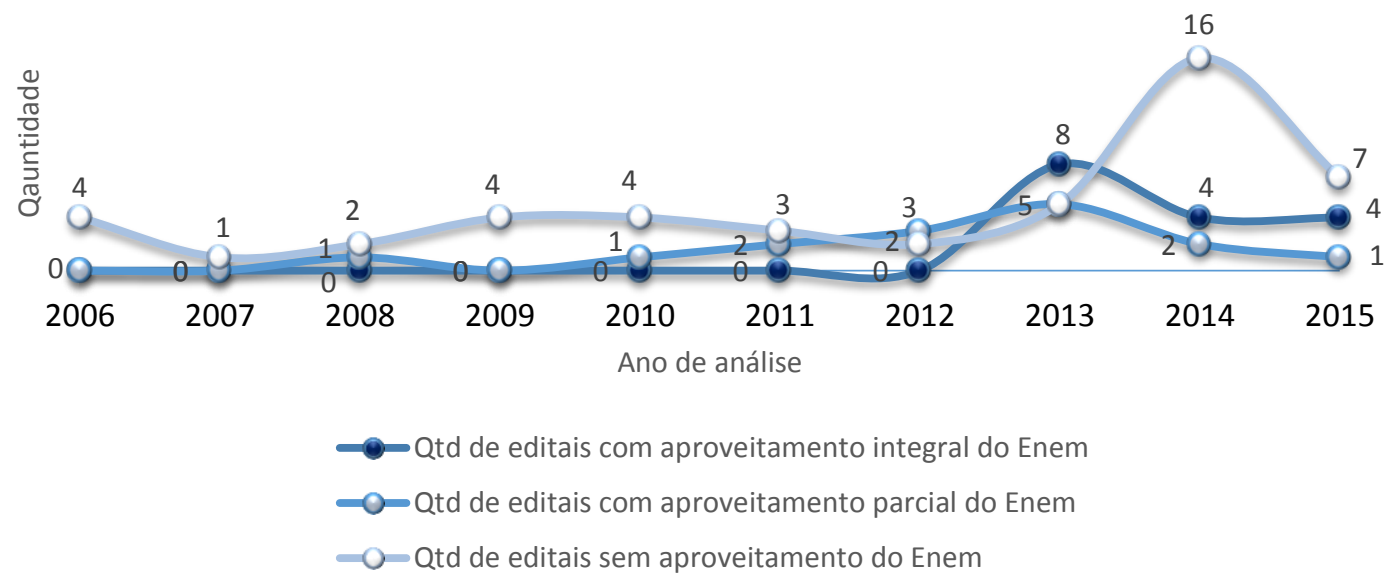

Aparentemente, os últimos dois anos (2014 e 2015) demonstraram um quantitativo menor do que aquele identificado em 2013 referente ao modelo de seleção via aproveitamento (parcial e integral) das notas do Enem. Entretanto, ainda não é possível emitir suposições se isso será uma tendência para os próximos anos. As linhas da última década traçadas no Gráfico 5.7 demonstram que desde 2010 havia Ifes se beneficiando parcialmente das notas do Enem, com valores ainda baixos, sendo uma em 2010 (UFPA); duas em 2011 e 2012 (UFPA e Ufsc); sendo marcada pela alta em 2013, quando houve cinco editais, sendo um da Ufsc, um da UFGD, dois da UFJF e um da UFU; com queda nos anos seguintes, sendo dois editais em 2014 (Ufsc e UFJF); e um edital localizado até maio de 2015, a saber o da UFG. Por outro lado, os editais que não recorreram à nota do Enem em seus processos seletivos só apresentam um valor menor que aqueles que o fizeram em dois dos dez anos analisados (2012 e 2013). Essa instabilidade manifesta a necessidade de se continuar acompanhando esses editais nos próximos anos para realizar inferências mais assertivas e indicar se as preocupações de Pereira (2016) serão agravadas.

Com menor recorrência entre os modelos de editais adotados, encontramos ainda duas Ifes (a UFJF e a Ufam) que, em 2013 e 2014, optaram por um modelo de processo seletivo contínuo, dividido em três etapas, consecutivamente às etapas do ensino médio. De acordo com esse modelo de seleção, há três módulos anuais de avaliação gradual e cumulativa. Para participar o candidato deve estar obrigatoriamente matriculado no ensino médio ou técnico ou 
Educação de Jovens e Adultos ou outra modalidade supletiva, porquanto candidatos com ensino médio (ou equivalente) concluído não podem prestar. Do mesmo modo, para ser admitido nos cursos de sua escolha, os participantes devem se inscrever e serem aprovados em todos os módulos do triênio.

Apesar da diversidade de formas de seleção de acadêmicos (como a avaliação seriada no ensino médio, o vestibular, o Enem, o Parfor, entre outros) verificada em nossos editais, tal como constatado por Martins, Leite e Lacerda (2015) ao analisarem os dados do Inep para ingresso de pessoas com deficiência na educação superior, ainda é possível concluir que, entre 2006 e maio de 2015, o vestibular prevaleceu como a principal forma de ingresso nos cursos de graduação para a formação de professores de Libras. Em nosso contexto, foram 56 editais cujos processos seletivos se nortearam pela organização de provas e vestibular, em comparação a 24 editais que adotaram ferramentas de seleção alternativas.

Esse perfil de editais favorece a obtenção de um panorama mais amplo da oferta de cursos para formação de docentes de Libras na última década e, em continuidade a esse desenho que vimos traçando, na próxima seção apresentamos dados referentes às pré-condições exigidas para o ingresso de candidatos aos cursos de formação de professores de Libras da Ifes aqui analisadas.

\subsubsection{Requisitos para o ingresso nos cursos de Letras Libras e Pedagogia bilíngue entre 2006 a 2015}

Em nossa terceira categoria de análise, voltamos nosso olhar para os requisitos exigidos pelas Ifes para os candidatos serem considerados aptos a participarem dos processos seletivos que regulam o ingresso nos cursos de Letras Libras e Pedagogia bilíngue. Como era esperado, majoritariamente, os editais foram direcionados para candidatos que "[...] concluíram ou estão em vias de concluir o Ensino Médio (2 ${ }^{\circ}$ grau ou equivalente).” (UFSC, 2011-2 [ingresso 20121 Presencial], p. 1). Para fins de equivalência de conclusão do ensino médio ${ }^{85}$, a UFT explicita, conforme Excerto 6, o perfil requisitado para o processo seletivo:

\footnotetext{
${ }^{85}$ Em conformidade com os artigos 36 e 38 da LDB/96 (BRASIL, 1996), "os diplomas de cursos de educação profissional técnica de nível médio, quando registrados, terão validade nacional e habilitarão ao prosseguimento de estudos na educação superior", da mesma maneira em que serão aceitos os cursos e exames supletivos que certifiquem a conclusão do ensino médio para maiores de 18 anos. Ademais, o $§ 2^{\circ}$ do artigo 38 da LDB/96 enfatiza que conhecimentos adquiridos por meios informais podem ser reconhecidos mediante exames. A esse respeito a Portaria normativa ${ }^{\circ}$ 16, de 27 de julho de 2011 (BRASIL, 2011a) dispõe sobre os critérios para a certificação no nível de conclusão do ensino médio com base no Enem.
} 


\section{Excerto 6}

[...] portadores de Certificado de Conclusão do Ensino Médio ou que tenham obtido certificado de conclusão no âmbito da modalidade de Educação de Jovens e Adultos; ou tenham obtido certificado de conclusão com base no resultado do Exame Nacional do Ensino Médio - Enem; do Exame Nacional para Certificação de Competências de Jovens e Adultos - Encceja ou de exames de certificação de competência ou de avaliação de jovens e adultos realizados pelos sistemas estaduais de ensino. (UFT, 2015-1 [ingresso 2015-1 Presencial] p. 1).

O requisito baseado somente na conclusão do ensino médio ou equivalente foi explicitado em uma grande parcela de editais analisados, sendo $70 \%$ do nosso universo de pesquisa (ou seja, 56 editais), e está amparado no artigo 44 da LDB/96, no qual consta a determinação de que os cursos de graduação estão "[...] abertos a candidatos que tenham concluído o ensino médio ou equivalente e tenham sido classificados em processo seletivo." (BRASIL, 1996).

Conforme discutido anteriormente, em um quantitativo menor, houve duas Ifes (sendo a UFJF e a Ufam) que adotaram o processo de seleção contínuo durante os três anos do ensino médio e, por isso, exigiam que os candidatos ainda estivessem cursando tal etapa da educação básica. Do mesmo modo, houve os editais que, por guiarem sua seleção pela nota do Enem, determinavam como principal requisito para candidatura às vagas ofertadas, a participação no referido exame (alguns inclusive exigiam uma pontuação mínima alcançada, tal como a UFU e a UFC); também encontramos os editais que ofertaram suas vagas para professores da rede de ensino e, para tanto, entre seus requisitos para ingresso o candidato deveria ser, necessariamente, professor ou estar cadastrado na Plataforma Paulo Freire ou ser participante do PAR; enquanto que os editais da UFPB direcionados para pessoas graduadas exigiam a comprovação do curso superior reconhecido pelo MEC com CR igual ou maior do que 7,0 (sete).

Entretanto, dentre os diversos requisitos para ingresso identificados em nosso corpus, deter-nos-emos na discussão daqueles em que a Libras consistiu uma exigência. Sendo assim, como ilustra o Gráfico 5.8, nossa análise demonstrou que menos da metade dos editais divulgados entre 2006 e 2015 a solicitou. 
Gráfico 5.8 - Percentual de editais que exigiram conhecimento em Libras nos processos seletivos para cursos de Letras Libras e Pedagogia bilíngue oferecidos entre 2006 a 2015.

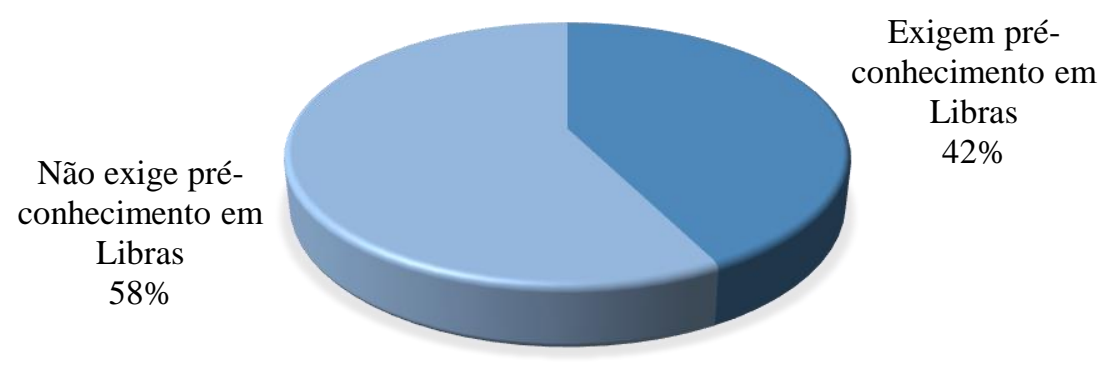

Em valores numéricos, $42 \%$ representam 34 editais que exigiram o pré-conhecimento em Libras diferentemente dos 46 editais, dentre os quais, a maioria se absteve, ou seja, não fez qualquer menção à exigência da Libras. No entanto, cabe ressaltar a postura do IFG que tornou essa decisão bastante explícita no texto do edital, como pode ser acompanhado no Excerto 7:

\section{Excerto 7}

O candidato ao curso não precisa saber a Língua Brasileira de Sinais - Libras, para concorrer à vaga. (IFG, 2014-2 [ingresso 2015-1 Presencial], p. 2, grifo nosso).

Cumpre lembrar que o Decreto $\mathrm{n}^{0} 5.626 / 05$, em seu artigo $5^{\circ}$, determina que os cursos de Pedagogia ou normal superior voltados para formação do docente de Libras, como é o caso do curso do IFG, devem ter a Libras e a Língua Portuguesa escrita como línguas de instrução (BRASIL, 2005). Tal orientação, em nossa compreensão, aparenta ser dificilmente exercida no caso de os graduandos desconhecerem a Libras, tendência que vem se acentuando nos últimos anos, conforme indica o Gráfico 5.9:

Gráfico 5.9 - Quantitativo de editais que exigiram conhecimento em Libras nos processos seletivos para cursos de Letras Libras e Pedagogia bilíngue oferecidos entre 2006 a 2015

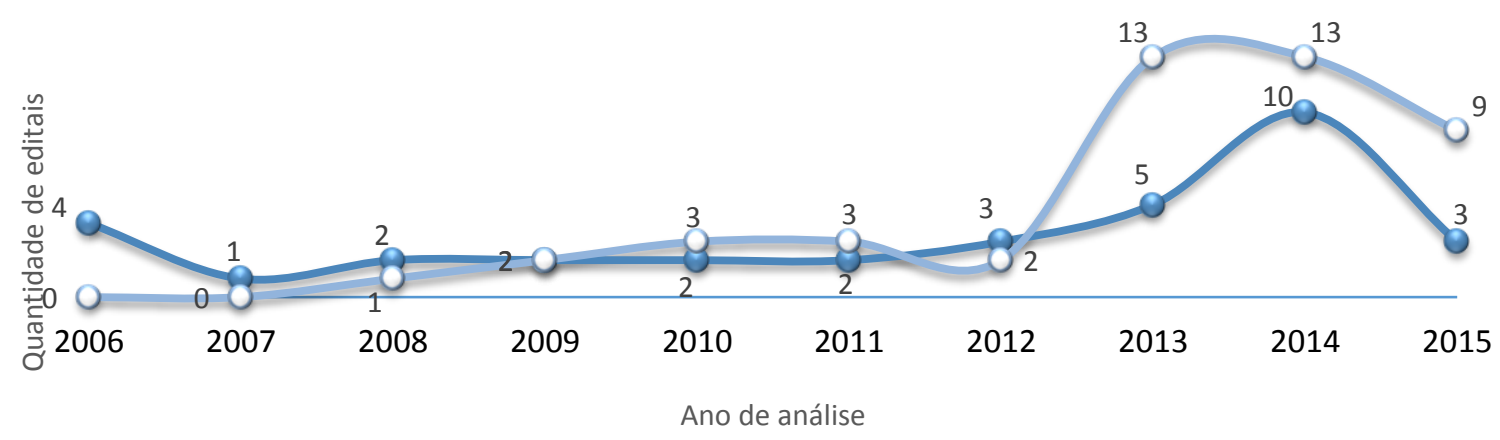


A análise do Gráfico 5.9 aponta que, junto com a ampliação de oferta de cursos de Letras Libras e Pedagogia bilíngue, nos últimos três anos, o número de Ifes que não solicitou o domínio em Libras foi superior àquelas que o fizeram, diferença bem menos expressiva nos anos anteriores, sendo inclusive observada em determinadas datas (2006, 2007, 2008 e 2012) a maior ocorrência de editais a exigir dos candidatos o pré-conhecimento em Libras.

Esse pré-conhecimento foi observado como caráter eliminatório, ou seja, os candidatos que não obtivessem uma pontuação mínima determinada pela Ifes não poderiam seguir na segunda etapa do processo seletivo como, por exemplo, foi aplicado pela UFRN (2013-1 [ingresso 2013-2 Presencial]; 2014-1 [ingresso 2014-2 Presencial]) que chegou a requerer de $50 \%$ a $70 \%$ de acertos na prova de Libras, para que o candidato pudesse ser considerado "apto" a concorrer às vagas do referido vestibular.

O Ines (BRASIL, INES ${ }^{86}$, 2008-2 [ingresso 2009-1 Presencial]; 2009-2c [ingresso 2010-1 Presencial]; 2011-2b [ingresso 2012-1 Presencial]), por sua vez, também realizou uma primeira seleção com base no resultado da prova de Libras, determinando, por exemplo, em 2011, que os candidatos com notas inferiores a 50\% na prova de conhecimento de Libras seriam eliminados. Além do critério eliminatório, diferente da UFRN, o Ines estabeleceu que os pontos adquiridos na avaliação da Libras seriam computados para efeitos de classificação geral do candidato.

Ocorreu ainda em nossa análise de identificarmos no edital da UFG (2013-2 [ingresso 2014-1 Presencial]) a exigência da comprovação do domínio em Libras, por meio da verificação de habilidades e conhecimentos específicos, contudo, restrita ao curso de bacharelado em Letras Libras, isto é, o curso de tradução e interpretação Libras/Português. Em síntese, a Ifes responsável por tal processo seletivo divulgou no mesmo edital a oferta de vagas para os cursos de bacharelado e licenciatura em Letras Libras, considerando importante ao futuro profissional intérprete e tradutor da Libras apresentar conhecimentos prévios nas línguas em questão, mas não avaliou a mesma necessidade para os futuros docentes da Libras, fato que seria no mínimo questionável. Afinal, qual seria a lógica e a concepção de ensino de línguas apresentadas por instituições que entendem que o futuro professor de Libras não precisa acumular conhecimento prévio nesse sistema linguístico, embora considerem isso necessário ao futuro profissional tradutor e intérprete?

\footnotetext{
${ }^{86}$ Tendo em vista que os editais do Ines concernentes ao período entre 2006 e 2012 foram localizados somente via DOU, utilizamos a grafia da sua referência como "BRASIL, INES".
} 
Como se sabe, a maioria dos vestibulares, e isso não se restringe aos cursos de Letras, exige de seus candidatos o domínio de uma língua estrangeira como o inglês, o espanhol ou o francês, fato comprovado durante a análise de nossos editais, onde nos deparamos com essa cobrança feita, por exemplo, pela UFU (2013-2 [ingresso 2014-1 Presencial]), pela UFG (20082 [ingresso 2009-1 Presencial], 2009-2 [ingresso 2010-1 Presencial]) e pelo Ines (BRASIL, INES, 2006-1b [ingresso 2006-1 Presencial], 2006-2c [ingresso 2007-1 Presencial], 2007-2b [ingresso 2008-1 Presencial], 2008-2 [ingresso 2009-1 Presencial]). Em instituições como a UFPA (2011-2 [ingresso 2012-1 Presencial]) também foram incluídos os idiomas alemão e italiano, além de todos esses, a Ufsc (2012-2 [ingresso 2013-1 Presencial], 2013-2 [ingresso 2014-1 Presencial], 2014-2 [ingresso 2015-1 Presencial]) integrou a Libras como mais uma opção para a prova de L2 feita pelos candidatos de seu processo seletivo.

Contudo, a postura da Ufsc não representa todas as Ifes, pois se analisarmos, a título de exemplo, os editais divulgados pela UFG exigem dos candidatos (surdos ou ouvintes) ao seu curso de Letras Libras o conhecimento de uma língua estrangeira moderna, seja o espanhol, o inglês ou o francês, mas não a Libras, a qual deverá ser a língua mais presente em sua formação. Em nossa visão, são nessas pequenas atitudes que podemos vislumbrar a sobrevalorização do bilinguismo de elite (SKUTNABB-KANGAS, 1981; CAVALCANTI, 1999) e o desprestígio relegado ao bilinguismo de contextos minoritários/minoritarizados (CAVALCANTI, 2011) no qual a Libras está inserida. Entretanto, não seriam essas Ifes, responsáveis pela formação de professores de Libras, que deveriam trabalhar em prol da desconstrução dessas relações de poder assimétricas? Essa postura não deveria estar manifestada desde o planejamento de seus processos seletivos? Apesar do exposto e de a maioria de editais localizados que não exigia conhecimento da Libras por parte dos candidatos, não podemos deixar de salientar os $42 \%$ de editais encontrados que fizeram a exigência de seus participantes apresentarem certificação comprovada de que são instrutores surdos de Libras (UFSC, 2006-2 [ingresso 2006-2 EaD], p. 1); fluência em Libras (por exemplo, UFSC, 2006-2 [ingresso 2006-2 EaD], p. 1; BRASIL, INES, 2006-1b [ingresso 2006-1 Presencial], p. 21); domínio de/em Libras (por exemplo, UFPR, 2014-2 [ingresso 2015-1 Presencial]; UFRN, 2013-1 [ingresso 2013-2 Presencial], p. 1); compreensão mínima da Libras, por meio de Teste de habilidade específica (por exemplo, UFT, 2015-1 [ingresso 2015-1 Presencial] p. 13) ou avaliação prática em Libras (por exemplo, UFRN, 2014-1 [ingresso 2014-2 Presencial], p. 1; UFRN, 2015-1 [ingresso 2015-2 Presencial], p. 1; UFPE, 2014-2 [ingresso 2014-2 Presencial], p. 1-2).

Destarte, seja como "domínio em Libras", "fluente em Libras” ou como “compreensão mínima", 34 editais tornaram explícito o requisito de conhecimento da Libras. Exceto na 
apresentação do certificado como instrutor de Libras, nas demais situações as Ifes organizaram suas próprias avaliações para mensurar o domínio da Libras de seus participantes, processo que exploramos na sequência, durante a subcategoria "a prova de conhecimento em/sobre Libras".

\subsubsection{A prova de conhecimentos em/sobre Libras}

Um primeiro questionamento que levamos para a análise desta subcategoria foi identificar como foi avaliado o domínio da Libras exigido como um pré-conhecimento por algumas das Ifes investigadas, ou seja, as provas contemplam conteúdos "sobre" a Libras? Ou conteúdos “em” Libras? Parte dos editais analisados asseverou que a comprovação linguística da Libras seria efetivada "sobre" a língua de sinais e o contexto social, histórico, linguístico e educacional da surdez, tal como reportado nos Excertos 8, 9 e 10:

\section{Excerto 8}

\section{SEÇÃO V: DO PROCESSO SELETIVO}

Art.12. O candidato inscrito para o concurso de acesso para os cursos de graduação em Licenciatura Letras-Libras e em Bacharelado Letras-Libras será submetido a processo seletivo de caráter eliminatório e classificatório, constituído de duas provas, sendo 1(uma) prova de Redação e 1 (uma) prova de conteúdo específico, que ocorrerão na mesma data.

$\S 1^{\circ}$. Será atribuída uma nota de 0,0 (zero) a 10,0 (dez) à Prova de Redação (NPRed), que terá duração máxima de 1 (uma) hora.

$\S 2^{\circ}$. Será atribuída uma nota de 0,0 (zero) a 10,0 (dez) à Prova Específica (NPEsp), que terá duração máxima de 3 (três) horas e versará sobre a área da linguagem e surdez:

(a) Conteúdo da Prova Específica para o candidato inscrito no curso de Licenciatura em Letras Libras:

$\square$ Aspectos Linguísticos da Língua de Sinais Brasileira.

$\square$ Aspectos da Cultura Surda e da Comunidade Surda.

Aspectos da Educação de Surdos.

Ensino de Libras como L1 e L2. (UFRJ, 2014-2 [ingresso 2015-1 Presencial] p. 5, grifo nosso).

\section{Excerto 9}

Conteúdo Programático das Provas

$[\ldots]$

5. Libras

Comunidade Surda: organização política e cultural; Educação Bilíngue: Libras/Português no Cenário da Educação Brasileira e Maranhense.

Libras: aspectos legais - Leis n ${ }^{\circ}$ 10.098/2000 (acessibilidade); 10.436/2002 (Lei da Libras) e os Decretos no 5.296/2004; 5.626/2005.

Estrutura Organizacional da Libras: Parâmetros; categorias gramaticais (substantivos; adjetivos; verbos; pronomes pessoais e demonstrativos e advérbio de tempo). (UFMA, 2014-2 [ingresso 2015-1 Presencial] p. 17). 


\section{Excerto 10}

1.5. As Provas serão realizadas apenas na cidade de Recife/PE e compreenderá uma única fase, constituída de Prova Objetiva (THE - Teste de Habilidade Específica) e Prova Discursiva (Redação). $[\ldots]$ ANEXO I

CONTEÚDO PROGRAMÁTICO DA PROVA OBJETIVA

1. Histórico Geral da Educação de Surdos

2. Histórico da Educação de Surdos no Brasil

3. Filosofias da Educação de Surdos: Oralismo, Comunicação Total e Bilinguismo

4. Legislação da Língua Brasileira de Sinais (Libras): Lei $n^{\circ}$ 10.436/2002 e Decreto $n^{\circ}$ 5.626/2005

5. A tradução e interpretação Libras x Português. (UFPE, 2014-2 [ingresso 2014-2 Presencial], p. 1-14).

No Excerto 8, a UFRJ anunciou que o conteúdo da prova específica de Libras seria acerca das temáticas envolvendo a linguagem e a surdez exigindo conhecimentos como o ensino de Libras como L1 e L2, aspectos linguísticos, educacionais e culturais. Como pode ser lido nos Excertos 9 e 10, além de envolver o conteúdo linguístico e da comunidade surda, a UFMA e a UFPE, respectivamente, também solicitaram dos participantes o domínio sobre os aspectos legais, históricos e filosóficos do contexto da educação de surdos. Diante da indicação feita pelas Ifes de que nas provas seriam abordados conhecimentos sobre a Libras, cabe levantar as primeiras, mas não menos inquietantes, indagações: seria coerente cobrar conhecimentos "sobre" a Libras para ingresso na educação superior? Como os candidatos egressos do ensino médio (ou equivalente) acumulariam instrução sobre tais particularidades linguísticas, culturais, históricas, legais e educacionais da Libras e do contexto surdo?

Os estudos que incidem, por exemplo, sobre o ensino da Libras como L1 e como L2 não são, seguramente, disponibilizados na educação básica, quiçá em cursos de extensão em Libras. Importa considerar que nos anexos do edital de 2015 da Ufra (2015-1 [ingresso 2015-2 Presencial], p. 6), foi emitido o quadro de disciplinas do primeiro semestre do curso de Letras Libras, no qual constavam disciplinas como, por exemplo, fundamentos da educação de surdos, história da educação de surdos e linguística aplicada ao ensino de línguas. Aparentemente, os conteúdos das disciplinas que seriam ministradas durante o curso estão sendo cobrados por algumas Ifes aos candidatos antes de seu ingresso, aliás como requisito para tal. Portanto, seria condizente com a realidade brasileira cobrar esse pré-conhecimento por parte dos inscritos (surdos ou ouvintes) no processo seletivo? Como pode ser vislumbrado, algumas Ifes (não apenas as que elegemos como exemplos nos referidos excertos) julgaram que sim.

Cabe salientar que, inclusive, houve Ifes, como a UFRJ e a UFPE, cujos processos seletivos não exigiram os usuais conteúdos do ensino médio, tais como Matemática, Química, Biologia, História etc. Conforme demonstrado nos Excertos 8 e 10, além da prova específica 
sobre Libras, houve apenas a exigência da prova de redação. No caso da UFPE, o tema da redação foi A importância da formação universitária para surdos, ou seja, temática que focalizou o domínio específico sobre a Libras, ao invés dos conhecimentos escolares.

A prova da UFT também centrou seu exame na redação com tema disparador pautado nos conhecimentos específicos, a saber: Novas tecnologias e a comunicação na comunidade surda; e por outro lado aplicou uma avaliação em Libras de conhecimentos gerais. Nessa prova, verificamos questões como, por exemplo, uma, na qual é projetada a caricatura do jogador de futebol Neymar, e, em seguida, questionado sobre qual o esporte praticado por essa pessoa famosa. Em outra questão, o candidato deve assinalar se o que cai da árvore são folhas, minhocas ou borboletas e, na sequência, observamos uma questão que exige do participante a identificação das cores da bandeira brasileira a partir de sua imagem. A análise da referida avaliação nos permite inferir que se lança mão dos conhecimentos escolares em detrimento de um processo seletivo exclusivamente baseado na avaliação de um domínio do vocabulário básico da Libras, o que pode denunciar uma visão distorcida e empobrecida do que representa o domínio nesse sistema linguístico, o descrédito em seus conhecimentos ou, ainda, a representação do surdo pela perspectiva da deficiência/ineficiência.

Abdicar da verificação dos conhecimentos acumulados nas disciplinas escolares seria uma medida compensatória de quem pesa a defasagem do histórico escolar que recaí sobre grande parte dos surdos, sobretudo, em virtude das condições desiguais de acesso aos conteúdos curriculares? Entretanto, não podemos deixar de refletir que se o acesso aos conhecimentos escolares pelos surdos pode ter sido prejudicado nas últimas décadas, o mesmo provavelmente ocorre perante os estudos específicos acerca da surdez e da língua de sinais. Como já apresentado no capítulo introdutório, a Libras foi, recentemente oficializada (BRASIL, 2002) e, até então, o seu espaço na educação de surdos era reprimido, usado para divulgar os seus malefícios (VIEIRA-MACHADO, 2010) ou como uma ponte para se alcançar o aprendizado da Língua Portuguesa, estratégia que rompia com a L1 do aluno surdo tão logo este apresentasse os primeiros avanços na L2 (SILVA, 2005).

Ainda recentemente, cabe destacar que, segundo Albres (2014), durante a graduação em Letras Libras ofertada pela Ufsc, um dos desafios mais flagrantes foi o estágio curricular obrigatório. Segundo a autora, foi extremamente complicada a criação de espaços em que se pudesse observar e desenvolver práticas pedagógicas de formação para surdos como professores de Libras. Em algumas localidades do país, não existiam escolas bilíngues para desenvolver o estágio ou a oferta de disciplinas curriculares de Libras e, mais complexo ainda 
foi o estágio de ensino de literatura visual ${ }^{87}$, cujo conteúdo era, até então, “[...] inexistente tanto em escolas de surdos quanto em cursos de Libras como L2." (ALBRES, 2014, p. 94).

Portanto, diante desse contexto, a nosso ver, o foco em atividades metalinguísticas, ou seja, que buscam refletir a respeito do funcionamento linguístico da Libras, deveria ser contemplado durante o curso e não a priori, sendo para esse momento prévio, talvez, mais produtivo a análise de como o usuário interage por meio da Libras. Entendemos que ainda não há garantias de que os surdos lograriam maior êxito em um ou outro modelo de avaliação, mas abrindo espaço para a dúvida, considerando este um momento de construção de instrumentos bilíngues de avaliação, é possível que as referidas Ifes estejam experimentando novos caminhos para determinarem o acesso aos cursos de formação para professores de Libras.

Fortalecendo a evidência desse momento de sondagem a que nos referimos, devemos destacar também os editais que abordaram o domínio da Libras sob a avaliação "em” Libras, isto é, foram contempladas questões de conhecimentos gerais apresentadas em língua de sinais, como se depreende dos Excertos 11, 12, 13 e 14:

\section{Excerto 11}

5.2. O THE será coletivo, consistirá de uma prova objetiva, com questões de múltipla escolha e será transmitido em vídeo na Língua Brasileira de Sinais (LIBRAS).

5.2.1. As questões de múltipla escolha versarão sobre conhecimentos gerais utilizando a Língua Brasileira de Sinais (Libras), considerarão domínio de conteúdo e interpretação adequada de situações apresentadas. (UFRN, 2014-1 [ingresso 2014-2 Presencial], p. 4, grifo nosso).

\section{Excerto 12}

4. DA PROVA

[...] 4.1.1 - A prova de Conhecimentos Gerais formulada na Libras será objetiva. O candidato assistirá a cada questão formulada na Libras duas vezes e assistirá às quatro alternativas de respostas na Libras. Após cada questão, marcará a resposta correta no caderno de prova e, depois de serem apresentadas as 15 (quinze) questões, passará as alternativas marcadas para o cartão- resposta. (UFSC, 2006-2 [ingresso 2006-2 EaD], p. 3, grifo nosso).

\footnotetext{
${ }^{87}$ De acordo com Albres (2014), as disciplinas de Metodologia de Ensino em Literatura Visual e Estágio em Literatura Visual, constantes no curso de licenciatura em Letras Libras da Ufsc, tinham por objetivo explorar os elementos da Libras a partir de diferentes gêneros literários desenvolvidos nesse sistema linguístico, sobretudo a partir da produção de vídeos.
} 


\section{Excerto 13}

\section{PROCEDIMENTOS GERAIS DAS PROVAS}

[...]7.7 Haverá, para cada candidato, um caderno de provas para resposta às 20 (vinte) questões objetivas de múltipla escolha com os enunciados disponibilizados apenas em Libras, sobre Conhecimentos Gerais e Específicos ${ }^{88}$ e 9 (nove) questões objetivas de português e língua estrangeira moderna disponibilizadas apenas em língua portuguesa. (UFPR, 2014-2 [ingresso 2015-1 Presencial], p. 5, grifo nosso).

\section{Excerto 14}

Composição e Aplicação da Prova Objetiva

9.31 Conforme opção do candidato pela Língua (Libras ou Português), na forma do subitem 6.6 deste Edital, a Prova Objetiva será composta de:

a) Prova de Libras: 20 (vinte) questões objetivas de múltipla escolha, disponibilizadas apenas em Libras por meio da apresentação de um vídeo.

b) Prova de Português: 20 (vinte) questões objetivas de múltipla escolha, disponibilizadas apenas em Português na modalidade escrita. (UFAL, 2015-1 [ingresso 2015-2 Presencial], p. 9, grifo nosso).

Portanto, as provas apresentam conteúdos de conhecimentos gerais e específicos, mas disponibilizados por meio da Libras aos candidatos que devem comprovar o domínio no sistema linguístico avaliado, concomitantemente, aos conhecimentos ali contidos, incluindo Química, Biologia, Física e Matemática. Tal como explicitam os Excertos 13 e 14, essas questões são apresentadas apenas em Libras e isso nos deixa parcialmente preocupados por dois motivos. $\mathrm{O}$ primeiro motivo que nos gera certo desconforto diante de uma prova de conhecimentos gerais exclusivamente em Libras é o risco de nos esquecermos de que o processo de escolarização dos alunos surdos não ocorreu de forma homogênea, pois o que a história da educação de surdos nos revela são diferentes abordagens de ensino no país, tais como o Oralismo, a Comunicação Total e o Bilinguismo (MOURA, 2000; ALBRES, 2005; SILVA; FAVORITO, 2009; CHOI et al., 2011). Mesmo considerando que, nas melhores condições, uma parcela desse grupo de pessoas teve os estudos viabilizados de maneira bilíngue, isto é, em Libras e na modalidade escrita da Língua Portuguesa, tornar a sua prova monolíngue, seja em uma ou outra língua, é situar o surdo também como um sujeito monolíngue quando o seu universo linguístico, tal como assevera Maher (2007, p. 75) não se assenta sobre as mesmas normas monolíngues:

Diferentemente do sujeito monolíngue, cuja carga funcional da linguagem está inteiramente alocada em uma língua, o bilíngue tem essa mesma carga

${ }^{88}$ Conforme programa da disciplina, enquanto os conhecimentos gerais envolvem Biologia, Física, História, Geografia, Matemática e Química, por outro lado os conhecimentos específicos consistem em: 1) Política Nacional de Educação Especial na perspectiva da Educação Inclusiva; 2) Fundamentos históricos, legais, filosóficos e teórico-metodológicos da educação de surdos; 3) Movimentos surdos e aspectos culturais das comunidades surdas; e 4) Aspectos linguísticos da Língua Brasileira de Sinais - Libras (UFPR, $2014-2$ [ingresso 2015-1 Presencial], p. 18). 
distribuída em duas e, por isso, avaliar seu comportamento exclusivamente em uma delas é avaliá-lo apenas parcialmente. Além disso, é preciso atentar para o fato de que as competências do sujeito bilíngue não são fixas, estáveis: à medida que as exigências para cada língua mudam, a configuração do repertório do bilíngue também se modifica.

Defendemos que o aluno surdo bilíngue não é a soma de dois monolíngues "completos" (um em Língua Portuguesa e outro em Libras), pois em nossa concepção teórica já apresentada discordamos dessa ótica de bilinguismo idealizado. Além disso, em nossa leitura, quando o aluno surdo constrói seus conhecimentos escolares sob a presença de duas línguas, avaliá-lo em um único sistema linguístico (seja Libras ou o português) é avaliá-lo parcialmente, é fechá-lo em um único container, emprestando esquema quantitativo utilizado por Skutnabb-Kangas (1981) para mensurar bilíngues e monolíngues ideais. Respaldados em Maher (2007), acreditamos que o domínio do sujeito bilíngue não se concentra em um único casulo (metáfora utilizada pela autora), e a melhor forma de extrair o máximo de seus saberes é permitindo-lhe transitar entre as duas línguas que o constituem, considerando, inclusive, que empréstimos e mudanças de código são recursos riquíssimos os quais o falante bilíngue pode lançar mão.

Uma segunda preocupação com relação à prova de conhecimentos gerais e específicos ser avaliada por intermédio, exclusivamente, da Libras é referente a ausência de catalogação e divulgação de sinais para termos específicos de cada área do conhecimento, tal como relatado por diversos autores (MARINHO, 2007; STUMPF; OLIVEIRA; MIRANDA, 2014; KUMADA et al., 2015).

Em concordância com Marinho (2007), observamos que a maioria dos dicionários veiculados nos espaços sociais e educacionais contempla o vocabulário cotidiano, de uso geral. Assim, um dos maiores desafios na tradução da Libras em contextos escolares está na ausência de sinais que expressem os termos específicos de cada disciplina. Essa carência faz com que alguns intérpretes e docentes tomem a iniciativa de "criar" e/ou "convencionar" sinais específicos, que, sem a devida divulgação, resultam na diversidade de sinais, a qual, por sua vez, não deriva de variedades culturais e linguísticas da Libras (SILVA; KUMADA, 2013), mas sim da falta de comunicação entre esses grupos (STUMPF; OLIVEIRA; MIRANDA, 2014).

A demanda por glossários por área fez com que, inclusive, algumas Ifes tenham se dedicado à criação de glossários, manuários e sinalários ${ }^{89}$ da Libras, tal como o Ines com termos específicos da área pedagógica (atendendo especialmente a necessidade de seu curso de

\footnotetext{
${ }^{89}$ Os termos "manuário" e "sinalário" foram criados como uma tradução cultural para o contexto linguístico da Libras daquilo que nas línguas orais convencionamos chamar de glossários.
} 
Pedagogia bilíngue) e a Ufsc com o sinalário (atendendo especialmente a necessidade de seu curso de Letras Libras) (KUMADA et al., 2015). Diante dessa pluralidade de sinais e glossários por área criados no país sem a ampla divulgação ${ }^{90}$, como garantir que o vocabulário presente na tradução feita no exame possa contemplar a compreensão de todos os seus candidatos?

O Excerto 14 ainda nos chama a atenção, pois define que o surdo deve optar pela prova "apenas" em Libras “ou” em Português. Aqueles que fizeram essa opção teriam a prova disponibilizada somente na língua escolhida, desconsiderando, novamente, a condição bilíngue do sujeito surdo, que transita entre as línguas conforme suas competências linguísticas (MAHER, 2007). Decisão como essas estão pautadas em uma visão engessada da língua, na qual o bilíngue tem suas habilidades e competências aprisionadas em recipientes estanques, uma noção de bilinguismo com a qual nos distanciamos, conforme explanado no Capítulo 3, por destoarem de nossa interpretação de surdez como diferença e como contexto minoritário/minoritarizado. Ademais, tal decisão fere a orientação para promoção da acessibilidade nos exames nacionais determinados pela Nota Técnica ${ }^{\circ} 08$, de 20 de abril de 2011, na qual se recomenda como uma das condições de acessibilidade é que os exames propiciem:

Texto em formato digital acessível - língua portuguesa/Língua Brasileira de Sinais (Libras): disponibilização do exame em formato digital acessível, de modo que o texto seja apresentado em língua portuguesa em formato impresso convencional, tendo como opção para o estudante usuário de Libras a janela com a tradução e interpretação em Libras. (BRASIL, 2015b, p. 118).

Conforme a redação desse documento, o surdo deve ter seu exame acessível não em uma, mas em ambas as suas línguas, sendo na Língua Portuguesa e na Libras. Dito isso, somamos argumentos para justificar nosso receio com relação à proposta de articulação da prova de conhecimentos gerais ser disponibilizada, unicamente, em Libras (ou exclusivamente em português). Outra preocupação que acumulamos refere-se à organização feita na prova em Libras como requisito para ingresso aos cursos de graduação aqui investigados consiste no fato de verificarmos que, com exceção do Ines, as demais Ifes avaliaram apenas a habilidade de compreensão da Libras.

\footnotetext{
${ }^{90}$ Desde 2015, o Ministério da Ciência, Tecnologia e Inovação (atualmente submetido ao Ministério da Comunicação), por intermédio da Secretaria de Ciência e Tecnologia para Inclusão Social, tem apoiado um projeto ao qual estamos denominando de Rede Libras para, via plataforma do governo, serem unificados os vários glossários da Libras criados por instituições de diferentes localidades. O projeto dessa plataforma, a princípio, além de subsidiado pelo referido ministério, serviria para consulta, criação, validação e padronização dos sinais. Esta pesquisadora integra o grupo de pesquisa que idealizou a proposta da Rede Libras e tem acompanhado o desenvolvimento do referido projeto.
} 
Em concordância com Gesser (2012), no cerne da literatura especializada sobre o ensino de línguas orais, os estudos salientam quatro habilidades, isto é, compreensão e produção oral e compreensão e produção escrita. Nessa perspectiva, a fala e a escrita seriam consideradas habilidades produtivas (ou expressivas) e a leitura e a compreensão oral, habilidades receptivas. Segundo a autora, em Libras, essas habilidades estariam relacionadas à compreensão visual e à expressão em sinais e constituem-se como competências naturalmente interligadas e necessárias para promover uma comunicação e interação efetiva.

Sob essa ótica, torna-se novamente parcial a avaliação que se detém em verificar tão somente a competência da compreensão da língua, sendo que o seu uso demanda compreensão e produção. A produção da língua de sinais por meio da interação e ou arguição de uma temática foi contemplada apenas nos processos seletivos promovidos pelo Ines (conforme Excerto 15) que, inclusive, teve a preocupação de registrar esse material em mídia digital, como postulado no artigo 14 do Decreto no 5.626/05, no qual consta que as instituições federais de ensino devem “desenvolver e adotar mecanismos alternativos para a avaliação de conhecimentos expressos em Libras, desde que devidamente registrados em vídeo ou em outros meios eletrônicos e tecnológicos" (BRASIL, 2005, p. 29).

\section{Excerto 15}

4.1.2.5-A Prova de Libras avaliará proficiência correspondente ao nível básico de Libras, de acordo com os seguintes aspectos: a compreensão do tema proposto para a interação entre a banca e o candidato; coesão e coerência no desenvolvimento do tema;

4.1.2.6-As Provas de Proficiência em Libras serão gravadas em vídeo. (INES, 2014-2 [ingresso 2015-1 Presencial], p. 7, grifo nosso).

Desse modo, o Ines se sobressai, conforme o Excerto 15, por avaliar a compreensão e a produção do candidato na língua de sinais, sob um enfoque comunicativo (ALMEIDA FILHO, 2002), ou seja, no uso da língua por meio do desenvolvimento de um tema e da interação entre o participante e uma banca competente, responsável por avaliar os aspectos de coesão e coerência de sua apresentação. Concernente às demais Ifes que realizaram a exigência da Libras como pré-requisito de ingresso, como dito anteriormente, centraram-se exclusivamente na avaliação da compreensão de enunciados formulados em e/ou sobre Libras.

A respeito das Ifes que adotaram a avaliação da compreensão em e/ou sobre Libras, cabe tecer algumas considerações sobre o conteúdo dessas provas que, em algumas situações nos chamou a atenção. O primeiro texto base utilizado na prova do processo seletivo da UFPI (20151a [ingresso 2015-2 Presencial]), por exemplo, abordou como temática a Língua brasileira de 
sinais (Libras), mas em diversos momentos referiu-se a esta como "linguagem de sinais", tal como pode ser acompanhado no Excerto 16:

\title{
Excerto 16
}

A Libras é uma das linguagens de sinais existentes no mundo inteiro para a comunicação entre surdos. Ela tem origem na Linguagem de Sinais Francesa. As linguagens de sinais não são universais, elas possuem sua própria estrutura de país para país e diferem até mesmo de região para região de um mesmo país, dependendo da cultura daquele determinado local para construir suas expressões ou regionalismos. (UFPI, 2015-1a [ingresso 2015-2 Presencial], p. 2, grifo nosso).

A escolha terminológica por linguagem ao invés de língua é repudiada pelas comunidades surdas que buscam a valorização da Libras e o seu reconhecimento enquanto língua, constituída de elementos sintáticos, semânticos, fonológicos e morfológicos que a definem como um sistema linguístico natural, tal como oficializado pela Lei $n^{\circ}$ 10.436/02 (BRASIL, 2002). A diferença entre língua e linguagem é discutida por Quadros e Karnopp (2004, p. 24, grifo dos autores):

\begin{abstract}
Sabe-se que para o vocábulo inglês language encontram-se, no português, dois vocábulos: língua e linguagem. A diferença entre as duas palavras está correlacionada, até certo ponto, com a diferença entre dois sentidos da palavra inglesa language. A palavra linguagem aplica-se não apenas a línguas português, inglês, espanhol, mas a uma série de outros sistemas de comunicação, notação ou cálculo, que são sistemas artificiais não naturais. Por exemplo em português, a palavra linguagem é usada com referência à linguagem em geral, e a palavra língua aplica-se às diferentes línguas. $\mathrm{O}$ vocábulo linguagem, em português, é mais abrangente que o vocábulo língua, não só porque é usado para se referir às linguagens em geral, mas [sic] também porque é aplicado aos sistemas de comunicação, sejam naturais ou artificiais, humanos ou não.
\end{abstract}

Como pode ser visto, para as autoras o conceito de linguagem é projetado em um escopo mais amplo que abrange "[...] uma variedade de sentidos: linguagem musical, linguagem corporal, linguagem das abelhas, entre outras possibilidades" (QUADROS; KARNOPP, 2004, p. 24), ao passo que a língua assume uma sistematização linguística mais específica pertencente aos seres humanos e classificadas de acordo com a modalidade de percepção e produção, ou seja, na modalidade oral auditiva como a Língua Portuguesa, ou na visual espacial como a Libras. Nossa percepção a partir de nossa inserção nas comunidades surdas é que para os integrantes dessas, surdos e também ouvintes adeptos de uma abordagem bilíngue de uma concepção de surdez como diferença, a qualificação da Libras como linguagem representa o desprestígio dissimulado na escolha lexical. Em outras palavras, entendemos que a 
denominação da Libras como linguagem está associada a uma resistência a admiti-la como linguisticamente equiparada à língua oral, afinal dificilmente se encontrará referência a uma pretensa "linguagem portuguesa" (no lugar de Língua Portuguesa). Resistência que pode estar atrelada à discriminação com o bilinguismo em contextos minoritários/minoritarizados, diferente do que ocorre com o bilinguismo de elite, no qual as línguas de prestígio tendem, conforme Cavalcanti (1999), a ser supervalorizadas.

Além disso, o mencionado texto base no qual encontramos a Libras sendo identificada como linguagem não se restringe a essa polêmica terminológica. Em trechos anteriores é possível conferir o uso de outra expressão com a qual as comunidades de pessoas surdas usuárias da Libras não se sentem acolhidas, ou seja, a de deficientes auditivos, tal como exibe o Excerto 17:

\section{Excerto 17}

A Língua Brasileira de Sinais (Libras) é utilizada por deficientes auditivos para a comunicação entre eles e entre surdos e ouvintes. Para melhor nos inteirarmos dessa realidade é interessante que essa linguagem se faça conhecer, e que haja uma procura por ela com o interesse de aprendê-la.

Ao contrário do que imaginamos ao perceber a existência desse tipo de linguagem, a Libras não é apenas uma medida paliativa para se estabelecer algum tipo de comunicação com os deficientes auditivos [...]. (UFPI, 2015-1a [ingresso 2015-2 Presencial], p. 2, grifo nosso).

A escolha do termo "deficientes auditivos" para retratar os usuários da Libras se opõe aos discursos que permeiam os Estudos Surdos, os quais têm se empenhado para promover a ruptura da surdez com essa ótica patológica, pois em consonância com Lopes (2011, p. 8):

[...] a surdez como deficiência que marca um corpo determinando sua aprendizagem é inventada através do referente ouvinte, das pedagogias corretivas, da normalização e dos especialistas que fundaram um campo de saber capaz de "dar conta" de todos aqueles que não se enquadram em um perfil idealizado de normalidade.

Importa para a autora e para outros pesquisadores filiados aos Estudos Surdos, como Skliar (2016, p. 6), “[...] criticar os discursos clínicos, a medicalização, a ouvintização na educação dos surdos”, pois em consonância com Santana e Bergamo (2005) a mudança conceitual da surdez como patologia para sua aceitação como fenômeno social também pressupõe a mudança nas nomenclaturas. Nesta senda, a representação do surdo sob o foco de déficit auditivo, ou seja, naquilo que lhe falta para ser aos olhos da sociedade considerado normal é uma afronta ao respeito e valorização de sua condição linguística, cultural e identitária.

Esse conflito terminológico é problematizado no depoimento de Gesser (2006, p. 37): 
Então, vez por outra me referia aos surdos como "deficientes auditivos", e, em um dado momento da nossa conversa, a professora, irritadíssima e em um tom muito alterado, falou: "Surdo! Surdo! Você deve chamá-los de surdos! Se você pretende fazer pesquisa sobre estes indivíduos, por favor, eles são surdos e não deficientes!". O que ficou latente para mim durante nossa interação foi a profunda agressividade e incômodo dela; o que me levou a começar a monitorar a minha fala e a tomar muito cuidado para chamá-los sempre de surdos. $\mathrm{O}$ fato é que, na minha visão inicial, a palavra surdo conotava mais preconceito, e parecia que não era um uso sequer politicamente correto. Não tinha ideia, também, por outro lado, da carga semântica que os termos deficiente-auditivo, surdo-mudo, e mudo conotavam, constantemente observados em muitas falas de pessoas leigas na discussão e/ou de especialistas dentro de uma posição que toma a surdez como uma patologia.

Como se observa, a pesquisadora, ao descrever seus primeiros passos no contexto dos estudos sobre a educação de surdos, relembra que encontrou pouca tolerância e certa agressividade por parte dos sujeitos de sua pesquisa ao uso da nomenclatura "deficiente auditivo", e, anos mais tarde, compreendeu ser uma expressão associada a uma postura patológica da surdez. Esse termo recebe significativa rejeição por aqueles que não representam o surdo pela deficiência ou falta, mas pela concepção da diferença, aproximando-os e situandoos nos contextos e discursos que envolvem as comunidades linguísticas minoritárias/minoritarizadas, tal como os indígenas e os imigrantes que, sem deixarem de ser brasileiros, têm no português sua L2.

No rastro dessa lógica, convém refletir o paradoxo desse processo seletivo que visa selecionar futuros profissionais bilíngues, aplica um exame acessível em Libras e versa sobre conteúdos desse contexto sociolinguisticamente complexo, porém, reproduz nesses textos representações já há muito criticadas nos Estudos Surdos pelo seu viés ouvintista. Essa situação nos leva a compactuar com Lopes (2011), para quem a coexistência de duas línguas em uma instituição escolar é insuficiente para se concluir que elas se despiram totalmente da visão médica. Neste sentido, Skliar (2016, p. 8) define que "[...] a questão não está no quanto os projetos pedagógicos se distanciam do modelo clínico, mas no quanto realmente se aproximam de um olhar antropológico e cultural [...]".

Essa ambiguidade de estar parcialmente alinhado aos estudos bilíngues de cunho socioantropológico e, concomitantemente, posicionado nos discursos oralistas fomentados por adeptos e especialistas da área clínica são, em nossa compreensão, interpretados como resultados de um período ainda transitório que vivenciamos. Esse momento é caracterizado pelo tempo no qual não nos distanciamos completamente da ideologia clínica, tampouco incorporamos integralmente a teoria da surdez como diferença. De acordo com Skliar (2003, p. 
43, grifo do autor), trata-se do "[...] paradoxo da contemporaneidade, que supõe uma nãodistinção entre o antes e o depois, em virtude de que o passado não continua num presente que já foi, senão que convive com ele."

Nessa linha de raciocínio apregoada pelo autor, nossa leitura nos leva a crer que não podemos incidir sobre o binarismo de um passado de concepções patológicas sobre a surdez e de um presente (ou futuro) de concepções socioantropológicas, pois não há uma, senão múltiplas manifestações do tempo para significar o presente, na qual o passado e o porvir se hibridizam formando novas paisagens deste tempo no qual nos situamos. Nas palavras de Skliar (2003, p. 42):

\begin{abstract}
O tempo presente desdobrou-se, despregou-se, multiplicou-se em trajetórias tão dissímeis que já não existe um tempo presente, pelo menos num sentido unitário, onisciente, centralizador, senão uma multiplicidade de tempos presentes como talvez nunca antes nos tenha sido possível perceber e, menos ainda, compreender. Assim, o tempo (conhecido) torna-se insuficiente para reconhecer a si mesmo. E, por isso, precisamos de outro tempo para nos refazer e para refazer o tempo.
\end{abstract}

Esse autor que é também adepto dos Estudos Culturais nos remonta aos ensinamentos de Bhabha (2007), ao conceber a existência de um terceiro espaço que não está nem em um nem em outro lugar, mas sim no interstício. Esse "entre lugares", segundo Bhabha (2007), não é um espaço para purezas, mas para o hibridismo e a mestiçagem, no qual as contradições são habituais.

Assim, alinhados ao conceito de tempo (SKLIAR, 2003) e espaço (BHABHA, 2007) postulado por tais teóricos, ampliamos nossa visão sobre as contradições desveladas no contexto de acesso dos surdos aos cursos de formação para docência da Libras. Entendemos que o diferencialismo e o deficientismo (BEHARES, 2015) não estão totalmente polarizados e distantes, mas em tempos e espaços que se misturam, "contaminam-se" e se influenciam mutuamente. Em síntese, assimilamos em Bhabha (2007) ${ }^{91}$ ser infrutífera a busca por uma exímia pureza ou originalidade, seja do que venha a ser "patológico" ou "socioantropológico", pois:

É apenas quando compreendemos que todas as afirmações e sistemas culturais são construídos nesse espaço contraditório e ambivalente da enunciação que começamos a compreender porque as reivindicações hierárquicas de

\footnotetext{
${ }^{91}$ Salientamos que Bhabha (2007) não aborda em sua obra o contexto da surdez, mas abarca contribuições sobre a reflexão do conceito de cultura com o qual tomamos a liberdade de importar para a análise e discussão de nossos dados.
} 
originalidade ou "pureza" inerentes às culturas são insustentáveis, mesmo antes de recorrermos a instâncias históricas empíricas que demonstram seu hibridismo. (BHABHA, 2007, p. 67).

Evidentemente, a compreensão desse cenário não deve nos acomodar ou nos impedir de tecer críticas ao audismo (ou ouvintismo), na expectativa de se alcançar maior influência de representações favoráveis à compreensão do surdo em sua integralidade linguística, cultural e identitária. Apesar disso, a reflexão nos expõe a inviabilidade da busca por purezas situadas em um tempo e espaço que são, originalmente, constituídos pelo hibridismo e pela contraditoriedade.

Isso posto, após a projeção do panorama geral sobre os processos seletivos e editais de vestibulares destinados aos cursos de graduação para formação da docência em Libras, ofertados pelas Ifes, passamos para o próximo eixo de análise, no qual discutiremos as condições de acessibilidade ofertadas para candidatos surdos no acesso aos cursos aqui investigados.

\subsection{CONDIÇÕES DE ACESSIBILIDADE}

A Convenção Internacional sobre os Direitos das Pessoas com Deficiência (BRASIL, 2010a, p. 34) declara ser dever dos Estados partes assegurarem o acesso das pessoas com deficiência à educação superior, por meio da promoção de adaptações razoáveis. As adaptações razoáveis são definidas por tal documento legal como “[...] as modificações e os ajustes necessários e adequados que não acarretam ônus desproporcional ou indevido [...]" ofertados para garantir a igualdade de oportunidades. Essas adaptações razoáveis se coadunam com nossa expectativa de escola justa (DUBET, 2004), na qual vemos como necessário o tratamento diferenciado a determinados grupos que se encontram em desvantagem, especialmente, quando essas adaptações são guiadas pela intenção de igualar as condições de competição com os demais.

Sob essa ótica, o segundo eixo de análise deste estudo, pauta-se na verificação das condições de acessibilidade empenhadas para o acesso dos surdos aos cursos da educação superior voltados para formação de professores de Libras. Este eixo é composto por seis categorias e uma subcategoria, nas quais são abordadas a tradução para a Libras dos editais, a disposição de intérprete e/ou projeção da prova em Libras, o direito ao tempo adicional nos exames, a permissão do uso do Aasi, a correção diferenciada da prova de Língua Portuguesa e os requisitos para obtenção do direito de acessibilidade e/ou prioridade de candidatos surdos. 


\subsubsection{Editais traduzidos em Libras}

A fim de responder acerca do acesso das pessoas surdas aos cursos de graduação que formam professores de Libras, problemática conduzida na presente pesquisa, consideramos indispensável aferir como tem ocorrido a fruição desse direito de acesso aos processos seletivos, pois tal como figura no dispositivo legal que regulamenta a Libras:

Art. 14. As instituições federais de ensino devem garantir, obrigatoriamente, às pessoas surdas acesso à comunicação, à informação e à educação nos processos seletivos, nas atividades e nos conteúdos curriculares desenvolvidos em todos os níveis, etapas e modalidades de educação, desde a educação infantil até à superior. (BRASIL, 2005, p. 29, grifo nosso).

Ancoramos nosso entendimento sobre o conceito de comunicação à luz da Convenção Internacional sobre os Direitos das Pessoas com Deficiência, em que consta no seu artigo $2^{\circ}$ :

“Comunicação" abrange as línguas, a visualização de textos, o braille, a comunicação tátil, os caracteres ampliados, os dispositivos de multimídia acessível, assim como a linguagem simples, escrita e oral, os sistemas auditivos e os meios de voz digitalizada e os modos, meios e formatos aumentativos e alternativos de comunicação, inclusive a tecnologia da informação e comunicação acessíveis;

"Língua" abrange as línguas faladas e de sinais e outras formas de comunicação não-falada; (BRASIL, 2010a, p. 34, grifo nosso).

A mesma convenção citada referenda que cabe aos Estados partes não só assegurar o acesso à informação reconhecendo e promovendo o uso da língua de sinais, bem como “[...] fornecer, prontamente e sem custo adicional, às pessoas com deficiência, todas as informações destinadas ao público em geral, em formatos acessíveis e tecnologias apropriadas aos diferentes tipos de deficiência;" (BRASIL, 2010a, p. 45).

Compreendendo a Libras como parte integrante da comunicação e, por conseguinte, o acesso à comunicação e informação nos processos seletivos dos cursos de educação superior como um direito resguardado, antes de iniciarmos a leitura dos editais averiguamos se estavam disponíveis em Libras. Esse primeiro levantamento nos permitiu conferir que, entre os 80 editais selecionados, apenas 39\% deles foram localizados traduzidos para a língua oficial das comunidades de pessoas surdas do país, conforme pode ser acompanhado no Gráfico 5.10. 
Gráfico 5.10 - Percentual de editais disponibilizados em Libras nos processos seletivos para cursos de Letras Libras e Pedagogia bilíngue oferecidos entre 2006 a 2015.

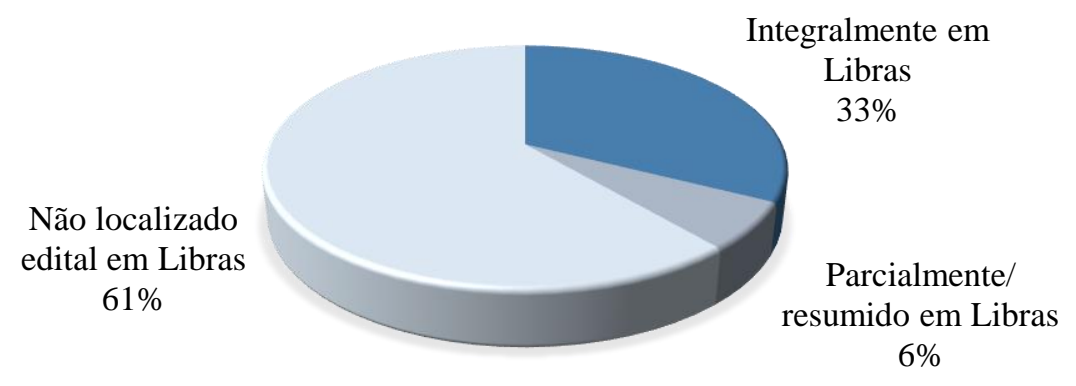

Surpreende que $61 \%$ dos editais não tenham sido localizados em Libras e também que dentre os 39\% dos editais disponibilizados em Libras, houve 6\% deles encontrados resumidos ou parcialmente traduzidos. Como pode ser conferido na Tabela 5.4, algumas Ifes que, a princípio, não tinham seus editais acessíveis em Libras nas primeiras edições de seus processos seletivos, passaram a fazê-lo em anos seguintes, como, por exemplo, o Ines, a Ufsc, a UFG e a UFC.

Tabela 5.4 - Distribuição de editais disponíveis em Libras por Ifes

\begin{tabular}{ccc}
\hline Edital em Libras & Quantidade & Ifes \\
\hline $\begin{array}{c}\text { Totalmente disponível em } \\
\text { Libras }\end{array}$ & 26 & $\begin{array}{c}\text { Ines, Ufac, Ufam, UFC, Ufersa, UFG, } \\
\text { UFGD, UFJF, UFPA, UFRJ, Ufsc, } \\
\text { UFU }\end{array}$ \\
$\begin{array}{c}\text { Parcialmente disponível em } \\
\text { Libras }\end{array}$ & 5 & IFG, UFPB, UFPI, UFT, Unifap \\
Não localizados & 49 & $\begin{array}{c}\text { Ines, Ufal, UFC, UFG, UFMA, } \\
\text { UFMT, UFPE, UFPR, UFRN, UFS, } \\
\text { Ufsc, Ufra, UFPB. }\end{array}$ \\
\hline
\end{tabular}

No caso da UFPB, entretanto, somente um edital referente ao ano de 2013 , dentre os sete editais, foi localizado traduzido parcialmente em Libras, sendo que as demais Ifes que se propuseram a tradução parcial do edital o fizeram em sua primeira oferta do curso, fato que pode desvelar propensão a um período de adaptação à proposta de se pensar o acesso à educação superior para candidatos surdos.

As razões pelas quais houve Ifes que optaram por não disponibilizar uma tradução integral dos editais são desconhecidas, mas é possível deduzir que essa medida torna também parciais e simplificadas aos candidatos surdos as informações dispostas sobre o processo seletivo. Cabe lembrar que o edital é o documento responsável por orientar as regras do 
vestibular, incluindo as normas para os candidatos surdos solicitarem os recursos de acessibilidade à realização do exame.

Para Goularte (2014), que investigou o acesso e a permanência de estudantes surdos aos cursos de graduação da UFSM, a Libras funciona como um elemento de sedução para atrair os surdos para a universidade, ou seja, muitos surdos escolhem ir para determinado curso ou IES em virtude de ser acessível em Libras. De acordo com entrevistas feitas por essa autora com sete participantes surdos, todos afirmaram que a presença de editais e de vídeos informativos ${ }^{92}$ disponibilizados na Libras foram cruciais para a escolha pela UFSM, um deles esclareceu que já havia prestado o vestibular da referida Ifes quando ainda não havia acessibilidade e que não fora aprovado, mas que após as mudanças promovidas como tradução do edital e da prova em Libras, correção da redação feita por profissionais da área, acompanhamento de intérprete, entre outros, ele conseguiu ingressar no curso acadêmico.

Desse modo, seria possível inferir que as Ifes que não valorizam a Libras durante os processos seletivos estariam intencionalmente deixando de lançar mão de um importante “elemento de sedução" (GOULARTE, 2014, p. 57) para candidatos surdos? Isso teria certo teor de intencionalidade?

Do que vimos em nossos dados, do universo de 80 editais, apenas 26 deles foram encontrados integralmente traduzidos para a Libras. Decerto, não podemos afirmar com precisão que o fato de não termos encontrado o edital em Libras signifique diretamente sua inexistência, considerando que alguns dos editais aqui investigados datam de uma década atrás. Logo, podemos conjecturar que os editais mais antigos não foram localizados em Libras por eventuais endereços eletrônicos que se perderam ou, ainda, pela recordação de que as redes sociais e mesmo a internet banda larga daquela época não favoreciam condições para a divulgação de vídeos ${ }^{93}$.

Contudo, se analisarmos o montante de editais ao longo dos anos e a sua respectiva tradução para a Libras, conforme Gráfico 5.11, verificamos um quantitativo ainda bastante tímido de Ifes que tornaram a acessibilidade dos editais aos surdos uma preocupação flagrante,

\footnotetext{
${ }^{92}$ Segundo Goularte (2014), a UFSM produz vídeos informativos pré-vestibular abarcando informações sobre o concurso vestibular, a rotina universitária, a assistência estudantil, tal como a Casa do Estudante para estudantes surdos de fora se instalarem gratuitamente em apartamentos acessíveis para surdos (com campainhas luminosas), além de destacarem a presença de outros surdos na universidade, bem como o acompanhamento constante de intérpretes de Libras em todas as atividades.

${ }^{93}$ De acordo com Ciriaco (2009), em 2005, mais da metade da população brasileira utilizava a internet discada, cuja velocidade máxima era de 56,6 kbps, velocidade considerada ineficiente para acessar vídeos com facilidade e agilidade.
} 
inclusive nos últimos anos em que já testemunhamos expressiva popularização de vídeos compartilhados e acessados na internet.

Gráfico 5.11 - Comparação do total de editais disponibilizados em Libras e sem a Libras nos processos seletivos para cursos de Letras Libras e Pedagogia bilíngue oferecidos entre 2006 a 2015

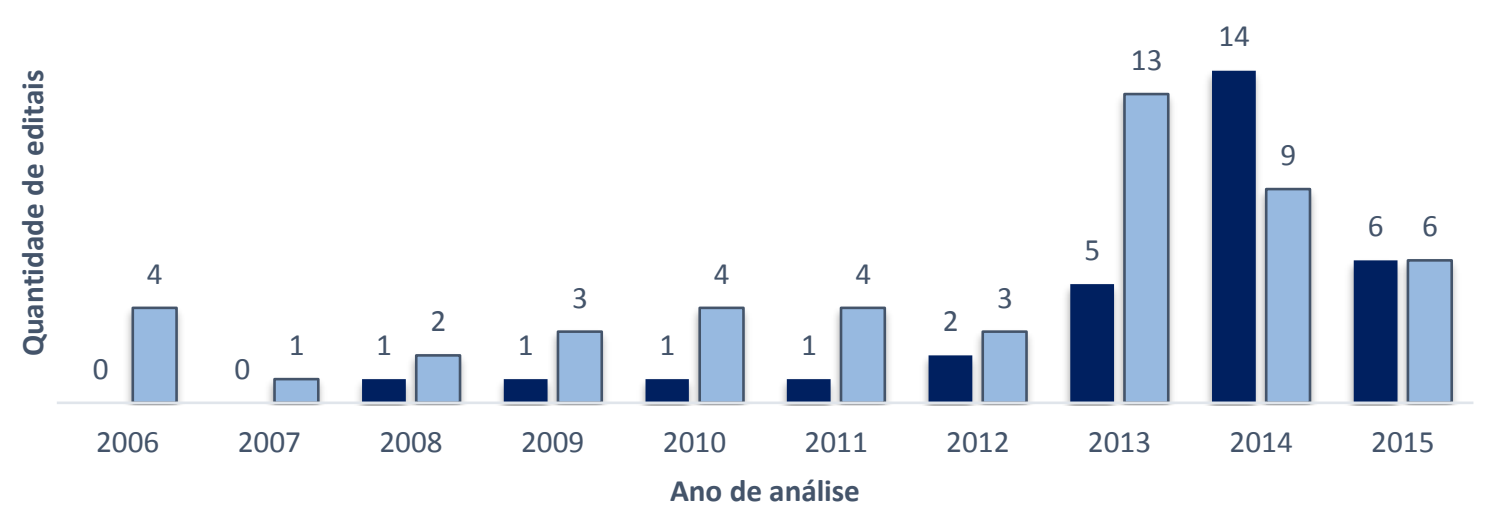

- Qtd de editais em Libras $\quad$ Qtd de editais sem a Libras

Ponderando que o ano de 2015 não foi abarcado integralmente, a comparação do total de editais disponibilizados em Libras e sem a Libras, conforme Gráfico 5.11, demonstra que somente em 2014, em relação aos anos anteriores, a quantidade de editais traduzidos foi superior àqueles sem a tradução. Com efeito, consideramos esse panorama abaixo das expectativas para cursos de graduação que devem promover a formação bilíngue em Libras aos seus acadêmicos.

Além disso, julgamos que, se os editais estivessem disponíveis em Libras, poderiam (ou deveriam) fazer essa indicação no próprio texto, tal como foi vislumbrado nos editais do Ines (Excerto 18) e da UFPI (Excerto 19):

\section{Excerto 18}

3.2.1 - Acessar o site www.ines.gov.br em que constam edital em português e em Libras. (BRASIL, INES, 2012-2b [ingresso 2013-1 Presencial], p. 58).

\section{Excerto 19}

16.1 O resumo do presente Edital encontra-se em vídeo na Língua Brasileira de Sinais (Libras) no endereço eletrônico: www.ufpi.br/copese (UFPI, 2015-1b [ingresso 2015-2 Presencial], p. 10).

A alternativa para aqueles interessados em obter informações a respeito do processo seletivo acessíveis em Libras foi apresentada pela Ufal, conforme Excerto 20: 


\section{Excerto 20}

As informações relativas ao Processo Seletivo por meio da Língua Brasileira de Sinais podem ser obtidas na Faculdade de Letras situada no Campus A. C. Simões, Tabuleiro dos Martins. Para isso, o candidato deverá realizar agendamento prévio na secretaria do Curso de Graduação em Letras - Libras: Licenciatura pelo telefone (82) 32141333. (UFAL, 2015-1 [ingresso 2015-2 Presencial], p. 16).

Assim, como demonstram os excertos apresentados, a preocupação em tornar os conteúdos dos editais acessíveis poderia ter sido divulgada em seu próprio texto, tal como colocado por algumas Ifes, seja por meio da disponibilização dos links ou de um espaço dentro da universidade para sanar eventuais dúvidas e obter informações em língua de sinais. Ademais, não podemos nos furtar de trazer à baila a informação complementar de que as universidades federais são incentivadas pelo MEC, desde 2005, por intermédio do Programa Incluir, a desempenharem ações que promovam o acesso de pessoas com deficiência às Ifes (BRASIL, 2016a). Nessa vertente, o Programa Incluir auxilia as Ifes na criação de núcleos de acessibilidade, "os quais respondem pela organização de ações institucionais que garantam a integração de pessoas com deficiência à vida acadêmica, eliminando barreiras comportamentais, pedagógicas, arquitetônicas e de comunicação.” (BRASIL, 2016a).

Apesar de não termos analisado se as Ifes pesquisadas possuem esses núcleos de acessibilidade, consideramos que, certamente, o Programa Incluir ${ }^{94}$ poderia ser, neste sentido, um aliado para a promoção da acessibilidade de pessoas surdas à educação superior, eliminando barreiras de comunicação que se centram na leitura dos editais disponibilizados exclusivamente na modalidade escrita da Língua Portuguesa.

Em consonância com Martins, Leite e Lacerda (2015), a promoção da acessibilidade nos exames nacionais deve ser assegurada aos candidatos desde o edital até o formulário de inscrição. Compactuamos com a premissa das autoras, compreendendo que a coerência na proposta bilíngue de um curso de Letras Libras ou de Pedagogia bilíngue deve iniciar desde a etapa de planejamento, uma vez que a legislação nacional orienta o processo seletivo a assistir os alunos surdos em sua língua natural, a saber, a Libras (BRASIL, 2005). Portanto, acreditamos que os cursos que se propõe ser bilíngues e formar profissionais na área para um novo estatuto da surdez como fenômeno social têm, evidentemente, um compromisso moral com as pessoas surdas de promover esse bilinguismo, inclusive, durante o seu ingresso. Nessa direção, a presença de intérpretes de Libras no exame e/ou a projeção da prova em Libras

\footnotetext{
${ }^{94}$ De acordo com Martins, Leite e Lacerda (2015), até 2010, o Programa Incluir disponibilizava recursos para universidades inscritas via edital. Em 2012, o repasse financeiro foi destinado apenas às Ifes já contempladas com projetos aprovados em anos anteriores e, em 2013, os recursos foram alocados diretamente para as unidades orçamentárias de 55 universidades federais.
} 
também são recursos necessários a essa acessibilidade, e, por essa razão, esse tema será palco de discussão da próxima categoria de análise.

\subsubsection{Intérprete de Libras e/ou projeção da prova em Libras}

Como já sabemos, a Libras foi um dos requisitos de ingresso em $42 \%$ dos editais analisados, o que garante sua presença nesses exames. Evidentemente, dentre os 58\% de editais que não fizeram exigência do pré-conhecimento em Libras, existem aqueles em que as Ifes não desenvolveram os tradicionais processos seletivos via vestibulares, ou seja, recorreram às ferramentas como o Sisu, o sorteio eletrônico, entre outros. Sendo assim, nesses contextos, não foi localizada nos editais nenhuma referência à promoção da acessibilidade em Libras nas provas, uma vez que estas não foram organizadas pela própria instituição. Recorrendo aos números, foram 20 editais de processos seletivos que não realizaram organização das provas, subtraídos de um universo de 80 editais. Referente aos 60 editais cujas Ifes produziram suas avaliações para o ingresso de candidatos nos cursos de graduação para formação de professores de Libras, 38 fizeram menção à acessibilidade por meio da presença do intérprete e/ou da projeção em Libras e, dentre os outros 22 editais que não se manifestaram com relação a tal recurso, 18 deles indicaram em sua redação que o candidato deveria solicitar o recurso especial necessário e quatro omitiram quaisquer apontamentos. Por intermédio do Gráfico 5.12 é possível acompanhar uma representação da acessibilidade em Libras na avaliação ofertada pelas Ifes em seus processos seletivos.

Gráfico 5.12 - Acessibilidade em Libras ofertada nos processos seletivos para cursos de Letras Libras e Pedagogia bilíngue oferecidos entre 2006 a 2015

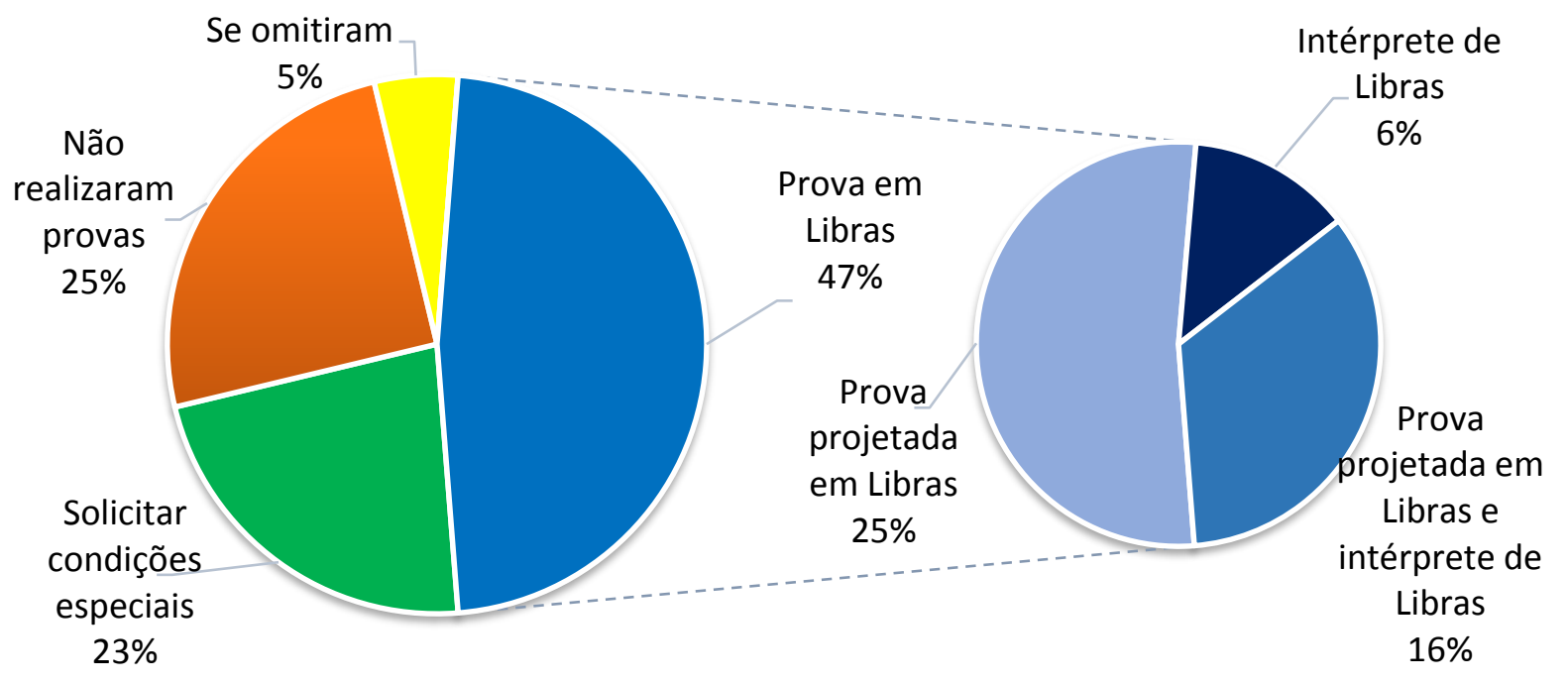


Dentre os 38 editais que contemplaram a acessibilidade em Libras, cinco deles asseguraram a presença do intérprete de Libras, 20 editais garantiram a projeção da prova em Libras e 13 ofertaram, simultaneamente, a projeção e o intérprete de Libras. Portanto, apenas $5 \%$ dos editais se omitiram com relação à promoção de condições de acessibilidade aos candidatos surdos durante o processo seletivo, pois em $23 \%$ desses, embora não tenham se pronunciado especificamente sobre a Libras, foi concedido aos candidatos requererem as medidas que julgassem necessárias e isso, a nosso ver, incluiria o direito de solicitar a presença do intérprete de Libras e/ou de obter a tradução de sua prova para a língua de sinais. Em apenas um episódio foi explicitado a supressão da presença do profissional intérprete de Libras, caso específico da Ufam, conforme o Excerto 21:

\section{Excerto 21}

5. DA PESSOA COM DEFICIÊNCIA E DO ATENDIMENTO DIFERENCIADO

5.1 - Ao candidato com deficiência (PcD) é assegurado o direito de requerer condições especiais ou atendimento diferenciado, para realizar as provas, nos termos da legislação vigente. Tais condições não incluem atendimento domiciliar, intérprete de libras e [sic] nem prova em Braille.

5.1.1 - As solicitações de atendimentos diferenciados e condições especiais serão atendidas segundo critérios de viabilidade e razoabilidade.

5.1.2 - O candidato que possua deficiência ou necessidade de atendimento diferenciado para a realização das provas deverá informar, no ato da inscrição, a deficiência ou a condição especial que motiva o atendimento diferenciado. (UFAM, 2014-2 [ingresso 2015-1 Presencial] p. 5-6, grifo nosso).

Como reproduzido no Excerto 21, a Ufam se posicionou disponível em atender solicitações dos candidatos com relação ao atendimento diferenciado para realização das provas, mas esclarece que essa concessão não se estende ao acompanhamento de um intérprete de Libras. Tal posicionamento, contudo, contrasta com a determinação do artigo 21 do Decreto $\mathrm{n}^{\mathrm{o}} 5.626 / 05$ (BRASIL, 2005, p. 29, grifo nosso):

Art. 21. A partir de um ano da publicação deste Decreto, as instituições federais de ensino da educação básica e da educação superior devem incluir, em seus quadros, em todos os níveis, etapas e modalidades, o tradutor e intérprete de Libras - Língua Portuguesa, para viabilizar o acesso à comunicação, à informação e à educação de alunos surdos.

$\S 1^{\circ} \mathrm{O}$ profissional a que se refere o caput atuará:

I - nos processos seletivos para cursos na instituição de ensino.

Por outro lado, como dito anteriormente, foram várias as Ifes como a UFMA (2014-2 [ingresso 2015-1 Presencial], p. 15), a UFPE (2014-2 [ingresso 2014-2 Presencial], p. 6) e o Ines (INES, 2014-2 [ingresso 2015-1 Presencial], p. 6-7) que dispuseram em seus editais o 
intérprete como um recurso a ser disponibilizado, como pode ser observado nos Excertos 22 e 23:

\section{Excerto 22}

6.8. Haverá no dia das provas a presença de tradutor-intérprete de Libras, não sendo necessário ser feita a solicitação por parte dos candidatos. (UFPE, 2014-2 [ingresso 2014-2 Presencial], p. 6).

\section{Excerto 23}

A acessibilidade para candidatos é solicitada no anexo I, em um "Formulário para Solicitação de Atendimento Especial":

[...] Recursos necessários:

Prova Ampliada - Tamanho da Fonte:

Prova em Braille

Ledor de Prova

Intérprete de Libras

Transcritor (preencher Folha de Resposta)

Tempo adicional

Móvel especial - Tipo:

(UFMA, 2014-2 [ingresso 2015-1 Presencial], p. 15).

Assim, no Excerto 22, observa-se que a UFPE estabelece ser desnecessário solicitar o recurso do intérprete de Libras, pois tal profissional será disponibilizado durante o exame para quem dele necessitar. Ao passo que, no Excerto 23, a presença desse profissional está condicionada ao preenchimento e entrega do formulário de solicitação de atendimento especial acompanhado de outros documentos comprobatórios, os quais discutiremos, posteriormente, no subitem 5.2.6. É possível que a opção da UFMA em dispor o recurso mediante a demanda requerida pelos candidatos tenha advindo da logística de direcionar ou organizar melhor o recurso do profissional tradutor e intérprete de Libras. Contudo, cabe refletir que a associação do direito de acessibilidade a uma série de exigências pode desproteger alguns candidatos que, apesar de necessitarem desse recurso, provavelmente não conseguiram atender as solicitações em tempo hábil.

Além disso, como pode ser acompanhado pelos Excertos 22 e 23, não se explicita o papel do intérprete nos exames, ou seja, se serviriam para traduzir as questões constantes nas provas em sua completude, para traduzir apenas os avisos e informes, para traduzir somente termos da Língua Portuguesa ou para mediar a comunicação entre o fiscal e o candidato em caso de dúvidas ou outras necessidades. Apenas o edital da UFU presta informações sobre a atuação do intérprete durante a aplicação da prova, conforme pode ser conferido no Excerto 24: 


\section{Excerto 24}

O candidato que necessitar de atendimento especial poderá solicitar:

[...] Intérprete de Libras (Língua Brasileira de Sinais) para sanar eventuais dúvidas ou fornecer informações sobre o Processo Seletivo durante a aplicação da prova, sempre que solicitado pelo candidato surdo ou com deficiência auditiva. (UFU, 2013-2 [ingresso 2014-1 Presencial], p. 7, grifo nosso).

Como observado no Excerto 24, o intérprete poderá contribuir para "sanar eventuais dúvidas ou fornecer informações sobre o Processo seletivo", o que não inclui a tradução da prova. A esse respeito, vale enfatizar o recomendado por Quadros (2004) no livro produzido pelo MEC intitulado $O$ tradutor e intérprete de língua brasileira de sinais e língua portuguesa, obra que integra o Programa Nacional de Apoio à Educação dos Surdos. Segundo a autora, ao tradutor e intérprete de língua de sinais, durante provas e concursos:

Sugere-se que se faça a tradução do português escrito para a língua de sinais de todas as questões da prova. O intérprete também deverá fazer a interpretação das instruções dadas na língua portuguesa falada e/ou escrita quando estes forem os casos. Durante a prova, o candidato pode dirigir questões relativas exclusivamente à língua portuguesa: significado, estrutura e vocabulário. Se por acaso, o candidato sugerir alguma escolha pessoal e solicitar a confirmação seja ela através do olhar, o intérprete deve lhe informar que apenas fará a tradução do português para a língua de sinais deixando claro as suas atribuições durante o processo. Em relação ao processo de seleção, o intérprete deve informar aos monitores e responsáveis qual a sua função e como se procederá a interpretação durante a execução das provas e do concurso de modo a garantir a acessibilidade. (QUADROS, 2004, p. 40).

Apesar disso, nossa problematização provém de essa prática não ser amplamente divulgada e o debate ainda ser necessário. De fato, essa é uma questão polêmica e já foi levantada em exames do Enem nos quais o intérprete traduziu apenas palavras soltas, recusando-se a traduzir as questões integralmente, alegando estar sob a orientação da coordenadoria regional da prova (PIRES, 2014). Se um exame nacional como o Enem (que inclusive pode definir via Sisu o acesso à educação superior) apresenta tais impasses, julgamos que seria também interessante refletir como o intérprete atuaria nos processos seletivos vestibulares das Ifes, apesar de não termos encontrado essa descrição na maioria dos editais analisados.

Pela redação dos editais, é possível inferir que houve outros contextos, além do referido no Excerto 24, nos quais o intérprete não foi o responsável pela tradução da prova, apesar de esta ter sido contemplada, porém, sob a projeção de vídeo da prova em Libras. A projeção foi o recurso escolhido, por exemplo, nos editais publicados pelo o IFG (2014-2 [ingresso 2015-1 
Presencial], p. 4), UFT (2015-1 [ingresso 2015-1 Presencial] p. 10), UNIFAP (2014-2 [ingresso 2015-1 Presencial] p. 7-8) e UFS (2014-1 [ingresso 2014-1 Presencial], p. 2; 2014-2 [ingresso 2015-1 Presencial], p. 2). Assim, como pode ser observado no Excerto 25 extraído do edital da Unifap e do Excerto 26 pertencente ao edital da UFS:

\section{Excerto 25}

8.2 Ao candidato surdo apto a concorrer às vagas destinadas a surdos, será garantido, sala especial com direito à prova diferenciada em forma de vídeo com as questões traduzidas em Língua Brasileira de Sinais - Libras, na forma estabelecida nos subitens 9.8, 9.9 e 9.9.1 e acompanhamento do Intérprete de Libras, não sendo necessário solicitar atendimento especial para isso. Esses candidatos terão, automaticamente, direito ao tempo adicional de 01 (uma) hora. (UNIFAP, 2014-2 [ingresso 20151 Presencial] p. 7-8, grifo nosso).

\section{Excerto 26}

b) Redação - terá caráter eliminatório e classificatório. Neste exame será apresentado um tema a ser desenvolvido pelo candidato através de um texto dissertativo-argumentativo, em prosa. A proposta de redação será projetada em Libras se, no momento da inscrição, o candidato optou por esta modalidade. Além disso, haverá a presença de intérpretes nas provas de redação para assegurar maior acessibilidade aos candidatos surdos ou com deficiência auditiva. [...]

2. A prova objetiva de Leitura e compreensão de textos em língua portuguesa terá todas as questões projetadas em Libras para o candidato que fez esta opção no momento da inscrição. As questões serão apresentadas em sequência, que será repetida três vezes. Após um intervalo de quinze minutos, o conjunto de questões será apresentado novamente, agora sendo repetidas duas vezes. Além disso, haverá a presença de intérpretes nas provas para assegurar maior acessibilidade aos candidatos surdos (UFS, 2014-1 [ingresso 2014-1 Presencial], p. 2; 2014-2 [ingresso 2015-1 Presencial], p. 2, grifo nosso).

Além da prova projetada em Libras, por meio do formato de vídeo, consta nesses editais a presença de intérpretes visando "assegurar maior acessibilidade" como assevera o Excerto 26, no qual se detalha que a tradução abrangerá tanto a prova objetiva como o enunciado da proposta de redação. Desse modo, cabe interrogar se a presença do intérprete seria voltada para a tradução de instruções concernentes à prova? De fato, isso não está explícito e a dúvida se acentua quando, por exemplo, a UFPI, conforme Excerto 27, declara que a prova será apresentada com o apoio do projetor e da presença de um professor da área de Libras e/ou tradutor e intérprete dessa língua. 


\section{Excerto 27}

5.3 Para os candidatos surdos que informaram a sua condição auditiva por ocasião da inscrição, a prova escrita, formulada em Língua Portuguesa (L1), será apresentada coletivamente duas vezes em Libras, com o apoio de projetor e a presença de professor da área de Libras e/ou de tradutor e intérprete da Língua Brasileira de Sinais.

$[\ldots]$

5.5.1 Após as apresentações das questões da prova em Libras, a proposta de redação será apresentada e repetida uma vez em Libras por professor da área e/ou tradutor e intérprete da Língua Brasileira de Sinais. (UFPI, 2015-1b [ingresso 2015-2 Presencial], p. 2, grifo nosso).

Vale frisar que a UFPI foi a única Ifes a indicar a possibilidade da apresentação das questões vir a ser realizada por um "professor da área”, pois nos demais editais verificados constou apenas a figura do profissional intérprete, que poderia estar acompanhada da projeção da prova em Libras. Em alguns editais foi informado que a projeção da prova em Libras seria feita por projetor (conforme Excertos 26 e 27) e, portanto, apresentada de forma coletiva e, em outros editais como, por exemplo, o do IFG e da Unifap foi indicada a possibilidade da prova ser acompanhada em vídeos exibidos em computadores individuais, conforme Excerto 28:

\section{Excerto 28}

3.7. Os candidatos surdos que optarem por concorrer às VAGAS DESTINADAS A SURDOS, serão direcionados para a sala onde a prova em vídeo será realizada. O vídeo contendo a prova em Libras será disponibilizado em computadores individuais. A sala contará com o acompanhamento do Intérprete de Libras, não sendo necessário solicitar atendimento especial para isso. Esses candidatos terão, automaticamente, direito ao tempo adicional. Caso necessite de outro tipo de atendimento especial o candidato deve proceder conforme disposições do item 3. (IFG, 2014-2 [ingresso 2015-1 Presencial], p. 4, grifo nosso).

Indubitavelmente, em nossa visão, a prova em computadores individuais acena maior respeito ao tempo de cada sujeito no que se refere ao ritmo de apreensão, raciocínio, conferência etc. Em outras palavras, considera que os candidatos podem apresentar tempo de assimilação distinto uns dos outros, pois permite repetir, pular ou retornar para as questões. Contudo, como ilustrado no Excerto 26, a maioria dos editais optou pela projeção coletiva das questões, repetindo-as três vezes para todos os candidatos ao mesmo tempo e, após quinze minutos, reapresentando-as outras duas vezes.

Apesar de nove editais se silenciarem a respeito do formato adotado (se em computadores individuais ou projeção coletiva), dentre os que fizeram tal menção é possível afirmar que a projeção coletiva da prova em Libras com ou sem o acompanhamento do intérprete foi o evento mais recorrente, sendo registrada em 22 editais, do que a prova em computadores individuais, mencionada por dois editais. 
Para Goularte (2014), a prova projetada em computadores individuais ou coletivamente em Libras ainda é a opção mais acertada que a tradução feita por tradutores e intérpretes de Libras, uma vez que, conforme experiência da UFSM quando se delega essa tarefa aos intérpretes, geralmente, o acesso ao conteúdo da prova é feito na hora da avaliação o que pode comprometer a qualidade da tradução. Segundo a autora, o trabalho de tradução pode exigir maior reflexão, impossibilitada pela tradução simultânea. Pensando nisso, a UFSM, passou a tradução para projeção em computadores individuais, contemplando não apenas os aspectos linguísticos, como também culturais que permeiam a passagem de uma língua oral auditiva para outra língua que é visual espacial. Essa consideração é relevante, conforme Goularte (2014), pois em algumas questões, por exemplo, nas quais aspectos musicais, rimas e fonemas estão envolvidos, para que haja a compreensão do aluno surdo é preciso, muitas vezes, lançar mão de recursos visuais durante a prova, algo que precisa ser previsto anteriormente.

Além disso, outra informação pertinente consiste em observar que somente em um edital da UFC garantiu-se a presença do intérprete de Libras durante a chamada para a realização da matrícula, como ilustra o Excerto 29:

\section{Excerto 29}

Art. 32 Durante a reunião[,] citada no Art. 28 deste Edital, será efetuada chamada nominal dos candidatos que figuram na LISTA DE CLASSIFICÁVEIS, para a realização da Solicitação de Matrícula, pela ordem de classificação, até que todas as vagas disponíveis sejam completadas ou que não haja mais candidatos da LISTA DE CLASSIFICÁ VEIS presentes.

$\S 1^{\circ}$ Haverá, durante a chamada do qual trata o caput deste artigo, acompanhamento por intérprete em Libras. (UFC, 2015-1 [ingresso 2015-2 Presencial], p. 5, grifo nosso).

A partir da análise dos editais, depreende-se que os que se atentaram para a acessibilidade em Libras aos candidatos surdos a fizeram majoritariamente voltados para o momento da prova, sem demonstrar maior preocupação com as etapas da inscrição e da matrícula. Além disso, não podemos deixar de problematizar o número considerável de 18 editais que, tal como no Excerto 21, delegaram aos candidatos a indicação da "condição especial" ou "necessidade de atendimento diferenciado para a realização das provas" (UFAM, 2014-2 [ingresso 2015-1 Presencial] p. 5-6). Essa medida, conforme ratificado em alguns processos seletivos foi condicionada à avaliação dos "critérios de viabilidade e razoabilidade" (UFAM, 2014-2 [ingresso 2015-1 Presencial] p. 5-6) e/ou, como o aludido Excerto 21 definiu, não se estendia ao intérprete de Libras. Em nosso olhar, medidas como essas podem afetar os candidatos que, desconhecendo os próprios direitos sobre o que podem reivindicar como 
atendimento diferenciado, embora deste necessite, abdiquem de fazê-lo pela ignorância de seus direitos.

A opção de delegar aos candidatos surdos a indicação de condições especiais necessárias para a prova não se restringiu ao intérprete de Libras, pois o direito ao tempo adicional também ficou muitas vezes implícito, condicionado à solicitação por parte do candidato. Barbosa (2011) já havia evidenciado tal situação quando analisou a produção escrita de surdos no vestibular de 2011 da UFS, pois, de acordo com essa autora, o intérprete havia sido um recurso disponibilizado para os candidatos surdos aprovados na perícia médica da referida instituição, entretanto, o tempo destinado à realização das provas equivaleu para surdos e ouvintes e, acaso solicitado pelo candidato surdo, o direito de tempo adicional poderia ser deferido.

Para continuidade da discussão referente ao tempo adicional, a próxima categoria de análise versará sobre o modo como os editais trataram esse direito dos participantes surdos.

\subsubsection{Tempo adicional}

Um tópico recorrente nos editais relacionava-se ao critério de tempo reservado para a realização das provas pelos candidatos surdos, sendo aclarada em 22 editais a possibilidade de se solicitar o direito de tempo adicional para a execução da avaliação durante o processo seletivo, como pode ser conferido na leitura do Excerto 30:

\section{Excerto 30}

7.1. Ao candidato com deficiência - auditiva, física, mental e visual - é assegurado o direito de requerer condições especiais para fazer as provas. Tais condições não incluem atendimento domiciliar, hospitalar ou transporte.

7.1.1. O atendimento diferenciado consistirá em: fiscal ledor; fiscal transcritor; prova ampliada; intérprete de Libras; acesso a mesa para cadeirante; ensalamento térreo; tempo adicional para a realização da prova; espaço para amamentação. Ao candidato surdo será garantido o direito à prova diferenciada em forma de vídeo com as questões traduzidas em Língua Brasileira de Sinais.

7.2. Somente será concedido o atendimento diferenciado àqueles candidatos que cumprirem o estabelecido neste Edital, observando-se os critérios de viabilidade e razoabilidade. $[\ldots]$

7.6. O candidato com deficiência que necessitar de tempo adicional para realização das provas, conforme previsto no artigo 40, parágrafo $2^{\circ}$, do Decreto $n^{\circ} .3 .298 / 99$ e suas alterações, deverá encaminhar o requerimento com justificativa, acompanhado de parecer emitido por médico especialista da área de sua deficiência.

7.6.1. O tempo adicional concedido será de até uma hora além do tempo normal previsto para os demais candidatos. (UFGD, 2013-1 [ingresso 2013-2 EaD], p. 4-5, grifo nosso).

No entanto, nas condições em que as provas foram projetadas coletivamente em Libras, os editais da Ufsc, UFPE e da UFPR, por exemplo, informaram que o tempo de cada questão 
seria idêntico para todos os candidatos (surdos e ouvintes), conforme pode ser acompanhado na redação dos Excertos 31 e 32:

\section{Excerto 31}

O tempo para cada questão será o mesmo para todos os candidatos. (UFSC, $2006-2$ [ingresso 20062 EaD], p. 3); (UFSC, 2008-1 [ingresso 2008-2 EaD], p. 3); (UFSC, 2014-1 [ingresso 2014-2 EaD], p. 5-6); (UFSC, 2009-1 [ingresso 2009-2 Presencial], p. 4); (UFSC, 2010-1 [ingresso 2010-2 Presencial] p. 5, grifo nosso).

\section{Excerto 32}

O tempo de cada questão apresentada no vídeo será o mesmo para todos os candidatos. (UFPR, 2014-2 [ingresso 2015-1 Presencial], p. 5, grifo nosso).

Nessa esteira, observado em oito editais e com redação bastante semelhante, Ifes como a UFPR, UFPE, a Ufal e a Ufsc enfatizaram que aos surdos não seria concedido tempo adicional, o que parece desconsiderar o artigo 27 do Decreto $\mathrm{n}^{\circ} 3.298 / 99$ :

Art. 27. As instituições de ensino superior deverão oferecer adaptações de provas e os apoios necessários, previamente solicitados pelo aluno portador de deficiência ${ }^{95}$, inclusive tempo adicional para realização das provas, conforme as características da deficiência.

$\S 1^{\circ}$ As disposições deste artigo aplicam-se, também, ao sistema geral do processo seletivo para ingresso em cursos universitários de instituições de ensino superior. (BRASIL, 1999, grifo nosso).

Nota-se que o parágrafo $1^{\mathrm{o}}$ do artigo 27 deste decreto, explicitamente, confere aos sujeitos surdos (classificados para efeitos desse decreto dentro do grupo de pessoas com deficiência) o direito de tempo adicional para realização da prova, inclusive as que tratam de processos seletivos para ingresso nos cursos de graduação. Nesse ponto, estariam os processos seletivos que dispõem sobre cursos de graduação para formação de professores de Libras (e que deveriam priorizar o acesso aos surdos) na contramão da legislação? Por qual razão tais Ifes decidiram por não estender o tempo da execução das provas aos candidatos surdos? Seria pelo fato da prova ser projetada coletivamente em Libras? Sobre esse critério, a UFPI também projetou suas provas em Libras e argumentou exatamente sobre esta condição a justificativa para a hora adicional, conforme Excerto 33:

\footnotetext{
95 Para os efeitos do Decreto $\mathrm{n}^{\mathbf{o}} 3.298 / 99$, o inciso II do artigo $4^{\circ}$ declara ser considerada "pessoa portadora de deficiência", entre outras, a deficiência auditiva caracterizada como a "[...] perda bilateral, parcial ou total, de quarenta e um decibéis $(\mathrm{dB})$ ou mais, aferida por audiograma nas frequências de $500 \mathrm{HZ}, 1.000 \mathrm{HZ}, 2.000 \mathrm{HZ}$ e 3.000HZ” (BRASIL, 1999).
} 


\section{Excerto 33}

5.3 Para os candidatos surdos que informaram a sua condição auditiva por ocasião da inscrição, a prova escrita, formulada em Língua Portuguesa (L1), será apresentada coletivamente duas vezes em Libras, com o apoio de projetor e a presença de professor da área de Libras e/ou de tradutor e intérprete da Língua Brasileira de Sinais.

5.3.1 Na primeira dessas apresentações, cada questão (enunciado e alternativas) será repetida uma vez. 5.3.2 Após a apresentação de cada questão, o candidato deverá marcar a sua resposta no caderno de prova e, depois de todas as questões serem apresentadas, deverá passar suas respostas para o cartãoresposta.

5.4 O tempo para responder cada questão da prova será o mesmo para todos os candidatos, exceto para os candidatos surdos e para os candidatos com deficiência cuja solicitação tenha sido atendida de acordo com o subitem 3.13 deste Edital.

5.4.1 Os candidatos inscritos para concorrer às vagas das ações afirmativas para surdos terão o tempo adicional de 01 (uma) hora para responder a prova por causa do tempo utilizado para apresentação das questões em Libras. (UFPI, 2015-1 [ingresso 2015-2 Presencial], p. 2, grifo nosso).

Apesar de ser um direito legal, conforme pode ser observado, a leitura da UFPI é de que “[...] por causa do tempo utilizado para apresentação das questões em Libras" (Excerto 33) os candidatos surdos teriam o direito de uma hora adicional. O Excerto 33, tal como o Excerto 30, determina que esse tempo adicional será de uma hora, mas cabe ressaltar que em muitos editais foi simplesmente indicado o assentimento ao tempo adicional, sem especificar o período, uma vez que o próprio Decreto no 3.298/99 não se manifesta a respeito desse quantitativo. Além disso, outras duas condições foram verificadas, ou seja, em alguns o tempo adicional era automaticamente garantido ao candidato inscrito como surdo (ou com alguma deficiência), enquanto em outros editais esse recurso era condicionado ao requerimento e à apresentação de documentos comprobatórios, discussão que abordaremos no subitem 5.2.6 mais adiante.

Ainda não é possível afirmar se o critério de tempo adicional constitui um diferencial na aprovação e consequente garantia de acesso dos surdos aos cursos de graduação, pois seriam necessários estudos específicos nesse âmbito, algo ainda não encontrado nas pesquisas levadas a cabo para fins deste estudo. Todavia, é inegável, que tal condição de acessibilidade é um direito legalmente assegurado e, portanto, acreditamos ser consideravelmente discutível a opção pela sua inexecução ou mesmo pela omissão dessa possibilidade, tal como foi constatado na leitura dos editais.

Assim, feitas as considerações no que diz respeito ao tempo adicional, prosseguimos com nossa discussão sobre condições de acessibilidade para surdos abordando a categoria "uso do Aasi". 


\subsubsection{Uso do Aasi}

O Aasi, também conhecido como aparelho auricular, aparelho auditivo ou prótese auditiva, é utilizado por muitas pessoas que possuem alguma perda auditiva, principalmente, por aquelas que não fazem uso da Libras, pois a amplificação sonora originada pelo seu uso pode favorecer, especialmente em casos de perdas leves e moderadas ${ }^{96}$, o aprendizado da língua oral e, consequentemente, sua comunicação por meio de tal modalidade linguística.

Observamos, contudo, que alguns surdos, mesmo com perda auditiva profunda e usuários da Libras, optam pelo uso do Aasi como um recurso útil para avisá-los de ruídos mais intensos como, por exemplo, em situações de avisos sonoros como uma buzina no trânsito ou um alarme disparado. Por outro lado, há sujeitos surdos como, por exemplo, o ator e produtor surdo Nelson Pimenta ${ }^{97}$ (TRAVESSIA DO SILÊNCIO, 2004), que afirma não utilizar o aparelho auditivo, pois seu uso gera incômodo e desconforto. Para esse público, certamente, ao invés do Aasi, o recurso favorecedor será a presença do intérprete de Libras, que poderá transmitir visualmente os avisos, regras e orientações aos candidatos surdos.

No entanto, em consonância com Skliar (2016, p. 14), entendemos que o contexto da surdez não é homogêneo, e ao "[...] falar dos surdos como totalidade, poderíamos cometer o mesmo erro que atribuímos à ideologia dominante e que criticamos", quer dizer, aprisionandoos em uma identidade una. Neste aspecto, somos instigados ao exercício de pensar em diversos recortes identitários que podem emergir dentro do escopo "identidade surda", desvelando não apenas uma identidade surda, senão várias.

No cerne do contexto sociolinguisticamente complexo da surdez, existem diferentes modelos de surdos que se aproveitam de recursos distintos que não são exclusivamente a Libras e que podem ser também ou somente o uso do Aasi. Assim, ao discutirmos acessibilidade dos candidatos surdos, e considerarmos os diferentes perfis desse universo, acreditamos ser necessário somar às nossas questões o uso do Aasi feito por surdos oralizados e/ou bilíngues.

\footnotetext{
${ }^{96}$ As classificações sobre a perda auditiva podem variar, mas, de acordo com a classificação divulgada pelo MEC (BRASIL, 1997), com base na classificação do Bureau Internacional d'Audiophonologie, e na Portaria Interministerial $\mathrm{n}^{\circ} 186$ de 10/03/78, a surdez leve compreende a perda auditiva até 40 decibéis (dB), a surdez moderada afeta os limiares entre 40 até $70 \mathrm{~dB}$, a surdez severa acomete os limiares entre 70 até $90 \mathrm{~dB}$ e a surdez profunda é a perda auditiva acima de $90 \mathrm{~dB}$. Cabe destacar que, no Decreto $\mathrm{n}^{\circ} 5.626 / 05$, é considerado como surdo aquele que, em virtude da perda auditiva, interage visualmente com o mundo a partir da Libras. Deficiência auditiva, por sua vez, consiste na "perda bilateral, parcial ou total, de quarenta e um decibéis (dB) ou mais, aferida por audiograma nas frequências de $500 \mathrm{~Hz}, 1.000 \mathrm{~Hz}, 2.000 \mathrm{~Hz}$ e $3.000 \mathrm{~Hz}$." (BRASIL, 2005, p. 28).

97 Nelson Pimenta é uma figura muito conhecida na comunidade surda, especialmente, pela sua atuação em e produção de materiais em Libras (livros, vídeos etc.) e por ser apresentador do programa Café com Pimenta transmitido na TV Ines, um canal de televisão brasileiro destinado ao público surdo e, portanto, com programação totalmente acessível em Libras.
} 
Reforçamos ainda que nossa concepção de surdo como um sujeito bilíngue independe de seu maior ou menor domínio da Língua Portuguesa na modalidade oral, pois compactuamos com o conceito mais amplo de bilinguismo postulado por Maher (2007, p. 79), que consiste basicamente na "[...] capacidade de fazer uso de mais de uma língua."

Diante disso, importa enfatizar que a menção ao uso do Aasi reverberou em 19 editais analisados. Grande parte das Ifes deliberou que a necessidade do uso do Aasi pelos candidatos surdos deveria ser informada e comprovada mediante requerimento acompanhado de documentos comprobatórios, tal como demonstra o Excerto 34:

\section{Excerto 34}

O candidato deficiente auditivo, usuário de aparelho auricular, deverá informar essa condição no Requerimento de Inscrição e comprovar sua necessidade, através de laudo médico, junto à Coperve/Ufsc, até a data supramencionada, caso contrário não poderá realizar as provas portando o referido aparelho. (UFSC, 2008-1 [ingresso 2008-2 EaD], p. 7; 2009-1 [ingresso 2009-2 Presencial] p. 9; 2014-1 [ingresso 2014-2 EaD], p. 9, grifo nosso).

Orientação semelhante figura nos editais da UFT, da UFU, da Unifap, da Ufal, do Ines e da UFPB ao condicionaram também o uso do Aasi informado via requerimento. Somente a UFRN e a UFPE autorizaram o uso do Aasi sem solicitar comprovações ou requerimentos por parte do candidato (Excertos 35 e 36):

\section{Excerto 35}

Durante a realização do THE e da Prova de Redação, será permitido ao candidato utilizar aparelho auditivo. (UFRN, 2015-1 [ingresso 2015-2 Presencial], p. 4, grifo nosso).

\section{Excerto 36}

Durante a realização das provas, será permitido ao candidato utilizar aparelho auditivo. (UFPE, 2014-2 [ingresso 2014-2 Presencial], p. 8, grifo nosso).

Nesses casos, averiguamos que a condição de acessibilidade disposta nos editais estaria mais próxima de um caráter de permissão (do uso do Aasi), e não necessariamente como um recurso de acessibilidade. De qualquer modo, para surdos que desconhecem a Libras, o uso do Aasi é essencial para se obter acesso às informações, tais como informes, possíveis dúvidas e avisos sonoros de início e término da prova.

Ainda que o candidato usuário do Aasi necessite comprovar sua necessidade, mediante laudo médio apresentado em data previamente estabelecida pelo edital, tratou-se de mais uma 
condição de acessibilidade recorrente em nossa análise. Importa mencionar ainda que outro recurso pertinente aos surdos oralizados e que apareceu somente nos editais da UFPB foi a leitura labial, cuja solicitação deveria ser referendada por meio de requerimento do candidato à Ifes.

Por outro lado, uma condição de acessibilidade aos candidatos surdos encontrada com maior frequência entre os editais investigados foi a prova de português diferenciada, sendo essa a categoria de análise contemplada na sequência.

\subsubsection{Prova de Língua Portuguesa diferenciada}

A ótica da surdez como diferença pressupõe o respeito à condição bilíngue dos sujeitos surdos não mais como indivíduos patológicos, mas como aprendizes do português como L2 e, em nossa leitura, isso perpassa o reconhecimento das influências em sua escrita que devem ser concebidas durante a correção das provas escritas elaboradas por estudantes surdos. Ancoramonos em Quadros e Schmiedt (2006) ao entender que, no percurso da aprendizagem da escrita da Língua Portuguesa, os alunos surdos precisam ser acompanhados de estratégias didáticas, materiais e professores com conhecimento em Libras e no ensino do português como L1. É necessário ter ciência do processo de influências que a Libras, como L1 das pessoas surdas, exerce sobre a aquisição da L2, além de realizar análises linguísticas contrastivas que permitam ao aprendiz estabelecer referenciais sobre as regras de funcionamento de cada língua.

Em consonância com Maher (2007) e Favorito (2006), o êxito na aquisição do português como L2 também depende dos programas de bilinguismo que permearam a formação do aluno surdo e, para Skliar (2016), ainda é preciso considerar as representações ouvintistas que o cercaram durante seu processo de escolarização. Neste sentido, há uma série de fatores que deve ser ponderado durante a análise da escrita de um aluno surdo, entendendo como esta se constitui a partir daquilo que foi oferecido pela escola durante sua trajetória educacional. Em suma, a nosso ver, se a escola não lhes proporcionou condições de se tornarem exímios usuários da Língua Portuguesa como L2, tal como falhou com uma grande parcela de alunos ouvintes para utilizar a escrita como L1 (BEHARES, 2015), é preciso que isso seja reconhecido durante a correção das avaliações.

Ao concentrarmos a atenção na prova discursiva e/ou de Língua Portuguesa diferenciada para candidatos surdos, notamos sua recorrência em 24 editais de nosso corpus. A leitura desses 24 editais indicou que, majoritariamente, as Ifes (tais como o IFG, a UFG, a UFMT, a UFT, a 
Unifap, a UFPI, a UFPE, a UFPB ${ }^{98}$, a Ufal e o Ines) preocuparam-se em garantir o direito de “correção e/ou avaliação" diferenciada no caso de candidatos surdos, sendo apenas duas Ifes (a Ufsc e a UFPR) que se pronunciaram sobre uma elaboração e/ou formulação da prova pensada para sujeitos usuários do português como L2, escolhas que podem ser comparadas nos Excertos 37 e $38:$

\section{Excerto 37}

6.3.2 Para os candidatos surdos, a[s] prova[s] de Português e Língua Estrangeira moderna será[ão] constituída[s] de 9 (nove) questões objetivas de português, elaboradas e avaliadas, assim como a questão discursiva, como segunda língua, em respeito ao disposto no Decreto Federal no 5.626/2005. (UFPR, 2014-2 [ingresso 2015-1 Presencial], p. 4, grifo nosso).

\section{Excerto 38}

10.6. Os candidatos surdos que optarem por concorrer as vagas destinadas a surdos, [sic] terão direito à correção diferenciada da redação, conforme inciso VI do Art. 14 do Decreto 5.626/2005). (IFG, 20142 [ingresso 2015-1 Presencial], p. 16, grifo nosso).

O Excerto 37 elucida que, para candidatos surdos, as questões envolvendo a Língua Portuguesa seriam "elaboradas e avaliadas", considerando-a, portanto, como L2. Destoando desse, o Excerto 38 pertencente ao edital do IFG declarou a "correção diferenciada", exclusivamente, para a prova de redação. Cabe sublinhar que em alguns editais a correção diferenciada se estendeu a questões (sobretudo as discursivas) de outras disciplinas, tais como Biologia, História, Geografia, entre outras.

Para dirimir as dúvidas advindas desse dissenso, recorremos à determinação do artigo 14 do Decreto $n^{0} 5.626 / 05$, em seu inciso VI, no qual promulga que as instituições federais de ensino devem "adotar mecanismos de avaliação coerentes com aprendizado de segunda língua, na correção das provas escritas, valorizando o aspecto semântico e reconhecendo a singularidade linguística manifestada no aspecto formal da Língua Portuguesa" (BRASIL, 2005 , p. 29, grifo nosso).

Vê-se, portanto, que o documento legal se pronuncia a respeito da correção diferenciada e não se aplica exclusivamente às provas de redação ou Língua Portuguesa, mas aos exames escritos. De qualquer modo, não julgamos as Ifes que pensaram no candidato surdo desde a

\footnotetext{
${ }^{98}$ A UFPB não menciona diretamente em seus editais a correção diferenciada da prova de redação, mas segue a Resolução 3/2010 do Conselho Superior de Ensino, Pesquisa e Extensão da referida Ifes, na qual consta em seu artigo $4^{\circ}$ que "a prova de redação dos candidatos surdos será corrigida por professores com competência para entender a linguagem escrita própria destes candidatos" (UNIVERSIDADE FEDERAL DA PARAÍBA, 2010, p.

2). Por essa razão consideramos a redação de tal documento na análise.
} 
elaboração da prova até o momento da correção, pois compreendemos que a administração de mecanismos coerentes na avaliação pode incluir a formulação da prova respeitando a condição bilíngue dos sujeitos surdos (BRASIL, 2005).

Além disso, cumpre salientar que, em nossa percepção, a prova de língua estrangeira praticada em alguns processos seletivos, tal como citada no Excerto 37, poderia ser aplicada em Língua Portuguesa, uma vez que esta já se constituiu como outra língua para os surdos. De acordo com informações pessoais adquiridas no contato com uma aluna surda do curso de mestrado do Centro de Estudos e Pesquisas em Reabilitação da Faculdade de Ciências Médicas da Unicamp e com a sua respectiva orientadora, o processo seletivo para ingresso no mencionado programa de pós-graduação adotou recentemente, em 2014, a avaliação em Língua Portuguesa como L2, em substituição a exigência do exame de proficiência em língua inglesa, aos candidatos de minorias linguísticas, dentre eles os surdos. Nesse viés, uma prova em Língua Portuguesa foi formulada e corrigida diferenciadamente, permitindo o ingresso de uma candidata surda já em nesse processo seletivo (informação verbal ${ }^{99}$ ). Cabe destacar que essa medida se manteve no edital de processo seletivo (vestibular) divulgado no segundo semestre de 2015 por essa instituição de ensino (UNIVERSIDADE ESTADUAL DE CAMPINAS, 2015). Sob essa perspectiva, se programas de pós-graduação já aceitam a proficiência em Língua Portuguesa como L2 para surdos, cogitamos que tal medida também poderia ser adotada nos processos seletivos para ingresso nos cursos de graduação.

Para auxiliar nas orientações como a elaboração e correção da prova diferenciada para surdos, bem como sobre outros recursos de acessibilidade a esse público, Daroque e Queiroz (2013) e Moreira e Fernandes (2008) ressaltam a ação de bancas especiais nos vestibulares, compostas por profissionais com experiência e conhecimento na área. Essa banca pode prover as condições de acessibilidade necessárias por meio de "[...] ferramentas tecnológicas, apoios didático-pedagógicos alternativos e com recursos humanos [...]” (DAROQUE; QUEIROZ, 2013, p. 150), atenuando as dificuldades e tornando as condições do exame mais igualitárias. Segundo Moreira e Fernandes (2008), a atenção com os candidatos surdos por parte dessa banca independe do grau de perda auditiva apresentada, pois serão considerados aqueles que utilizam a língua de sinais, assim como os que recorrem à leitura labial e resíduos auditivos.

Nas palavras de Moreira e Fernandes (2008), trata-se de tarefa da banca observar critérios diferenciados de avaliação do português escrito no que diz respeito às questões discursivas e prova de redação, potencializando o conteúdo ao invés da estrutura gramatical.

\footnotetext{
${ }^{99}$ Informação fornecida pela $\operatorname{Prof}^{\mathrm{a}} \operatorname{Dr}^{\mathrm{a}}$ Ivani Rodrigues Silva, em Campinas, em 2014.
} 
Apesar da contribuição e relevância das bancas especiais para a promoção do acesso de candidatos surdos à educação superior, em nossos editais foram pouquíssimas as Ifes (a UFG, a UFPI, a UFPB, o Ines e a Ufal) que indicaram contar com essa composição voltada à correção das provas produzidas por candidatos surdos, isto contrasta com a orientação da nota técnica 08/2011 (BRASIL, 2015b, p. 120), a qual expõe que "a correção da prova de redação dos candidatos usuários da língua portuguesa como segunda língua, deverá ser feita por profissional com formação na área."

É sobremaneira preocupante o fato de apenas 24 editais terem declarado a acessibilidade da correção diferenciada da Língua Portuguesa para candidatos surdos e que dentre esses, seja ainda mais raro aqueles que indicaram a presença de profissionais competentes para realizá-la. Em face desse cenário, é conveniente verificar o conteúdo dos editais acerca da possibilidade dos candidatos surdos realizarem vistas à prova de redação, inclusive impugnarem recursos ao resultado dessa avaliação. Assim, na sequência, discorremos sobre a subcategoria "interposição de recursos à prova de redação".

\subsubsection{Interposição de recursos à prova de redação}

Antes de iniciar a verificação da autorização para interposição de recursos por parte dos candidatos surdos à prova de redação, cabe enfatizar que 36\% (equivalente a 29) dos editais não realizaram prova de redação, fosse por opção de seu processo linguístico ou por comporem o quantitativo de Ifes pautado na seleção de candidatos via nota do Enem, histórico escolar da graduação, sorteio eletrônico, entre outros. Como representado no Gráfico 5.13, houve ainda 23 editais, equivalente a $29 \%$, que se omitiram sobre a possibilidade de interposição de recursos à prova de redação aos candidatos, ouvintes ou surdos. Muitos desses $29 \%$ de editais permitiam aos candidatos impetrarem recursos administrativos aos resultados ou à prova objetiva, mas nada manifestavam quanto à redação. Por outro lado, houve cinco editais que apresentavam redação aclarada sobre o impedimento de recursos aos resultados ou à correção da prova de redação, ao passo que 29\% (igual a 23 editais) deliberaram sobre a orientação aos candidatos para que fizessem vistas à prova de redação e/ou pudessem impugnar recurso a esta. 
Gráfico 5.13 - Possibilidade de interposição de recursos à redação nos processos seletivos para cursos de Letras Libras e Pedagogia bilíngue oferecidos entre 2006 a 2015

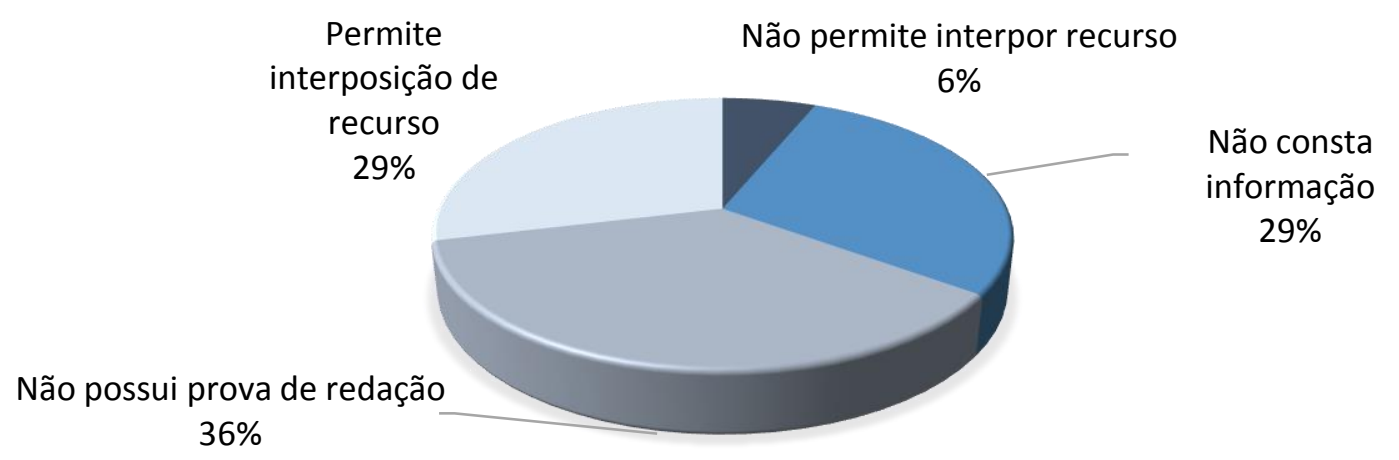

A análise desse gráfico nos remete à reflexão de que entre os 51 editais que previram a prova de redação em seus processos seletivos, somente 23 deles deliberaram positivamente sobre a interposição de recursos a esse exame. Em alguns casos, a proibição da interposição de recursos à redação foi bastante enfática, como retrata o Excerto 39:

\section{Excerto 39}

14. DOS RECURSOS

14.1. Caberá recurso contra o Gabarito Preliminar, Boletim Preliminar e Resultado Preliminar da Análise de Documentação Comprobatória. [...]

14.5. Não caberá recurso contra a correção da Prova de Redação (IFG, 2014-2 [ingresso 2015-1 Presencial], p. 18, grifo nosso).

A leitura que realizamos diante desse panorama é a grande dificuldade existente por parte das Ifes de administrar os processos seletivos considerando as especificidades dos candidatos surdos. Portanto, os editais deveriam ser mais explícitos com relação ao direito de correção diferenciada da prova de Língua Portuguesa, sobretudo da redação, etapa na qual se afere a desenvoltura do candidato diante da escrita dessa língua, não apenas como verificação do domínio dos aspectos gramaticais, bem como de seu uso e funcionamento de forma contextualizada. Não sendo estabelecido tal caráter diferenciado, outra medida seria aceitar a interposição de recursos às redações.

Sobre o ensino da escrita para surdos é necessário lembrar, como elucidado por Silva, Kumada e Nogueira (2012), que esses escolares foram, durante muito tempo (e em muitos casos ainda são), educados com os materiais didáticos e estratégias de ensino utilizados com alunos ouvintes, cuja Língua Portuguesa consiste na L1, sem terem reconhecidas suas especificidades no que se refere ao aprendizado desse sistema linguístico como uma L2. Nessa direção, em concordância com Lodi (2013), o ensino do português escrito para surdos não pode ser 
concebido sob a mesma ótica adotada na educação de aprendizes ouvintes, pois mesmo com a mediação de tradutores/intérpretes de Libras, surdos e ouvintes possuem vivências distintas da Língua Portuguesa.

O desconhecimento sobre as especificidades linguísticas e educacionais dos surdos, somados à escassez de pesquisas relacionadas a esse contexto, conforme Silva, Kumada e Nogueira (2012), trouxeram sérios prejuízos ao domínio da escrita por pessoas surdas. Essa afirmação pode ser reforçada com as pesquisas de Daroque (2011) e Bisol et al. (2010) ao identificarem, a partir de relatos de professores e universitários surdos, a leitura e a escrita entre os principais obstáculos no processo de formação na educação superior desse grupo de alunos.

Na mesma direção, Lima (2012) e Barbosa (2011) ao avaliarem o ingresso de pessoas surdas nos cursos de educação superior também destacaram as dificuldades enfrentadas, especialmente, com a prova escrita e de redação. De acordo com Barbosa (2011), ao analisar 14 redações de candidatos surdos ao processo seletivo para ingresso nos cursos de educação superior da UFS, mostrou-se nítida a influência da Libras na escrita dos candidatos surdos nos níveis ortográfico, morfossintático e semântico. Contudo, em que pese equívocos de natureza visual como, por exemplo, ao trocar "carro" por "carra" ou de natureza categorial ao redigir “colocar para carro" ao invés de "colocar no carro" (BARBOSA, 2011, p. 98), a autora ressalta que o entendimento do texto era, geralmente, preservado.

Apesar disso, na pesquisa realizada por Lima (2012) com cinco pessoas surdas, candidatas ao ingresso em um curso de Pedagogia, duas foram reprovadas devido ao desempenho insatisfatório na Língua Portuguesa, pois suas redações ao serem avaliadas sob critérios idênticos aos dos candidatos ouvintes foram consideradas desconexas e ininteligíveis. Segundo a autora, a ação demonstrou que a universidade longe de valorizar o aspecto semântico das redações, exigiu uma proficiência em Língua Portuguesa equivalente à de alunos ouvintes (LIMA, 2012).

Essa expectativa remonta ao que Skutnabb-Kangas (1981) critica quando afirma que o sujeito bilíngue tem sido visto, sob critérios quantitativos, como a soma perfeita de dois monolíngues completos. Como se ele precisasse comprovar domínio na Língua Portuguesa similar ao de um usuário desta como L1, mas isso sem questionar em qual contexto social esses sujeitos bilíngues foram produzidos, ou em outras palavras, sem considerar sob quais mecanismos os sujeitos bilíngues tiveram acesso aos dois códigos linguísticos.

Os equívocos da correção de uma redação que desconsidere não apenas o percurso escolar da maioria das pessoas surdas, como também a condição de falantes do português como L2, em nossa visão, contradizem os preceitos circunscritos na Portaria $n^{\circ} 3.284$, de 7 de 
novembro de 2003 (BRASIL, 2003). Esta dispõe a respeito dos requisitos de acessibilidade para pessoas com deficiência para a autorização e credenciamento de Ifes e na qual, em seu artigo $2^{\circ}$, visando assegurar o acesso à educação superior estabelece:

III - quanto a alunos portadores de deficiência auditiva, compromisso formal da instituição, no caso de vir a ser solicitada e até que o aluno conclua o curso: a) de propiciar, sempre que necessário, intérprete de língua de sinais/língua portuguesa, especialmente quando da realização e revisão de provas, complementando a avaliação expressa em texto escrito ou quando este não tenha expressado o real conhecimento do aluno;

b) de adotar flexibilidade na correção das provas escritas, valorizando o conteúdo semântico;

c) de estimular o aprendizado da língua portuguesa, principalmente na modalidade escrita, para o uso de vocabulário pertinente às matérias do curso em que o estudante estiver matriculado;

d) de proporcionar aos professores acesso a literatura e informações sobre a especificidade linguística do portador de deficiência auditiva. (BRASIL, 2003, p. 12, grifo nosso).

Do mesmo modo, cabe frisar que, embora não conste nos editais, também é direito de todos os candidatos (ouvintes e surdos) terem acesso aos critérios utilizados na correção de suas provas, incluindo a redação, algo previsto como um direito constitucional, conforme pode ser interpretado na leitura do inciso XXXIII do artigo $5^{\circ}$ da $\mathrm{CF} / 88$ :

\footnotetext{
XXXIII - todos têm direito a receber dos órgãos públicos informações de seu interesse particular, ou de interesse coletivo ou geral, que serão prestadas no prazo da lei, sob pena de responsabilidade, ressalvadas aquelas cujo sigilo seja imprescindível à segurança da sociedade e do Estado (BRASIL, 1988).
}

Evidentemente, estamos lidando com a exigência de se obter uma informação de interesse particular do candidato, cujo caráter reflete diretamente no dever da lisura e transparência dos processos seletivos desenvolvidos por instituições públicas. Lembramos ainda que o artigo $5^{\circ}$ encontra-se no segundo título da Carta Magna, o qual aborda os direitos e garantias fundamentais, que segundo Fonseca (2006, p. 9, grifo da autora) são aqueles que “[...] procuram transformar direitos humanos em direito positivo.” Nessa direção, se entendemos que os direitos positivos são aqueles em que se subjaz a obrigação de uma segunda pessoa em fazer algo pela primeira (BEAUCHAMP; CHILDRESS, 2002), estamos diante de um direito assegurado e de um dever estabelecido, em que constando ou não nos editais permanece sendo um direito, pois do contrário incorre em ação inconstitucional.

A nosso ver, direitos como, por exemplo, o de fazer vistas e interposição de recursos com relação à correção da prova (BRASIL, 1988), o de ter uma prova de Língua Portuguesa 
diferenciada respeitando-a como L2 dos candidatos surdos (BRASIL, 2003, 2005), o de obter tempo adicional para a realização das provas (BRASIL, 1999) e o de ser avaliado em Libras (BRASIL, 2003, 2005) como requisito para ingresso são fulcrais para o acesso das pessoas surdas à educação superior, em especial, aos cursos de formação de professores de Libras, aqui investigados, cuja prioridade é assegurada aos candidatos surdos. Uma vez que esses direitos não estejam integralmente preservados e/ou explicitados, julgamos que o processo de exclusão e as práticas de marginalização e invisibilização dos surdos podem ser reproduzidas.

Nessa mesma lógica, concebemos que a resistência de garantir condições de avaliação diferenciadas aos surdos por meio da omissão da acessibilidade ou da burocratização para sua obtenção podem mascarar os artifícios adotados por algumas Ifes no intuito de não descumprirem a legislação, mas ainda assim perpetuarem com as mesmas práticas excludentes exercidas tradicionalmente pela escola monolíngue e de viés oralista. A continuidade dessa discussão, sobretudo, a respeito da burocratização para a obtenção de direitos legais à acessibilidade e à prioridade, é abordada na próxima categoria de análise que trata sobre os requisitos para obtenção do direito de acessibilidade e prioridade.

\subsubsection{Requisitos para obtenção do direito de acessibilidade e/ou prioridade}

O direito às condições acessíveis durante os exames, tais como o acompanhamento de um intérprete de Libras, a projeção da prova em Libras, o tempo adicional, o uso do Aasi ou para concorrer dentro das vagas reservadas para surdos quando localizado nos editais foram condicionados à comprovação da surdez mediante atestado ou laudo médico e/ou exames e documentos clínicos.

Instituições como a Ufac e a UFMA determinaram que os documentos comprobatórios tivessem data de expedição até no máximo 90 dias. Outras Ifes como, por exemplo, a UFG (conforme Excerto 40), o Ines e a UFPI estenderam esse prazo para seis meses ou um ano como a UFPB e a UFS. Para tais contextos, como representado no Excerto 40, era comum encontrar exigências de que nos laudos deveriam constar a causa da surdez, o grau e espécie da perda auditiva, o número da Classificação Internacional de Doenças (CID), o número do Conselho Regional de Medicina do médico, além de apresentar a audiometria com e sem o uso da prótese auditiva (Aasi). Em algumas Ifes, exigia-se também que o laudo fosse emitido por órgãos públicos do Sistema Único de Saúde ou locais recomendados pela Ifes que promovia o processo seletivo. 
Frequentemente, seguir todas essas exigências concernentes ao laudo e/ou atestado médico, à audiometria e ao requerimento entregues na inscrição ainda eram considerados insuficientes para assistir o candidato referente às condições especiais para a realização da prova. Isso porque algumas Ifes, entre as quais, a Ufsc, a Ufac, a UFG (Excerto 40) e a UFS, asseveravam em seus editais que, após a entrega dos documentos, o candidato seria ou poderia ser convocado para perícia feita por junta médica da própria instituição, que decidiria pela condição especial, além de que o atendimento a essas condições estaria sob análise dos critérios de razoabilidade e viabilidade.

Dentro dessa categoria ainda nos chamou a atenção o fato de que muitos editais acolhiam a prioridade para surdos em suas vagas (tópico que será discutido em nosso terceiro eixo de análise), mas não realizavam um diálogo entre o processo de seleção e a matrícula. $O$ que observamos é que após o candidato ter solicitado condições especiais para a prova, comprovado clinicamente a perda auditiva, quando aprovado e convocado para a matrícula deveriam apresentar novamente laudos e exames médicos. Cabe destacar que a comprovação durante a inscrição era requerida, muitas vezes, como demonstra o Excerto 40, por meio de documentos originais, os quais o edital enfatizava que não seriam devolvidos.

Procedimentos como esses e outros denunciaram a imensa burocratização que os participantes surdos se defrontaram para terem acesso a um atendimento diferenciado na prova ou para ingressarem nas vagas reservadas para surdos. Nesse percurso, observamos que muitos candidatos surdos tiveram suas inscrições ou solicitações de condições especiais indeferidas, tal como ocorreu na UFG. Ao analisarmos a divulgação do resultado sobre a entrega da documentação dos candidatos que requereram tempo adicional e correção diferenciada dessa Ifes, notamos que, dentre as 104 solicitações de tempo adicional, somente 13 candidatos apresentaram documentação completa. Entre os 24 inscritos que solicitaram correção diferenciada da prova de Língua Portuguesa, somente quatro conseguiram entregar a documentação completa dentro dos padrões e prazos exigidos.

Portanto, alguns foram indeferidos por não apresentarem a documentação original, ou por ter sido emitida fora do prazo determinado no edital, outros porque o laudo médico não constava a justificativa do tempo adicional ou não indicava se a perda auditiva seria passiva de alguma melhora com o uso de uma prótese auditiva, entre outras. Semelhantemente, a UFT indeferiu 72 das 86 inscrições de candidatos surdos, enquanto a UFPB indeferiu três das 19 solicitações de atendimento especial para a prova, a primeira Ifes justificou o indeferimento pela falta de documentação completa, original, laudos no prazo determinado e a UFPB alegou 
que o laudo médico entregue não continha informações sobre a espécie, o grau, o nível de deficiência, a CID e as especificações das necessidades especiais.

Além da burocratização, que por si só nos preocupa, esses dados extraídos de editais e de documentos complementares localizados em nosso levantamento devem ainda ser tensionados à luz do empoderamento da área clínica para dirimir sobre aspectos essencialmente de cunho educacional, tal como representa uma avaliação para ingresso na educação superior. Observemos atentamente o Excerto 40, transcrito a seguir:

\section{Excerto 40}

2.42. O candidato PORTADOR DE DEFICIÊNCIA, conforme o Decreto n. 3.298, de 20/12/1999, que necessitar de tempo adicional para fazer as provas, deverá anexar, juntamente com o laudo médico, justificativa do médico especialista do tipo da deficiência, informando claramente no laudo médico que o candidato necessita de tempo adicional.

2.43. O candidato PORTADOR DE DEFICIÊNCIA AUDITIVA terá direito de correção diferenciada das provas discursivas de Biologia, Geografia, História, Língua Portuguesa, Literatura Brasileira e Redação, na qual serão adotados mecanismos flexíveis que valorizem os conteúdos semânticos dessas provas, de acordo com o Decreto n. 3.298, de 20/12/1999, e Decreto n. 5.626, de 22/12/2005. Para tanto, deverão entregar ou enviar (via Sedex) o original ou cópia autenticada em cartório do laudo médico conforme subitem 2.44 , que ateste essa deficiência, até o dia 15 de outubro de 2010.

2.44. O Laudo Médico deverá ser emitido em formulário próprio, disponível no sítio www.vestibular.ufg.br, obedecendo às seguintes exigências:

a) constar o nome e o número do documento de identificação do candidato, bem como o nome, o número do registro no Conselho Regional de Medicina (CRM) e a assinatura do médico responsável pela emissão do laudo;

b) descrever a espécie e o grau ou o nível da deficiência, bem como a sua provável causa, com expressa referência ao código correspondente da Classificação Internacional de Doenças (CID 10); c) no caso de deficiente auditivo, o laudo deverá vir acompanhado do original do exame de audiometria recente, realizado até 6 (seis) meses anteriores ao último dia das inscrições.

2.45. Somente serão corrigidas, em caráter diferenciado, as provas dos candidatos que tiveram o laudo médico deferido pela equipe multiprofissional, nomeada pelo Centro de Seleção para esse fim, cuja publicação será feita dia 16 de novembro de 2010.

2.46. Caso não atenda às exigências estabelecidas no subitem 2.43 , o candidato não terá as provas submetidas à correção diferenciada.

[...]

2.48. Os candidatos portadores de deficiência ou necessidades especiais deverão submeter-se, quando convocados, a [sic] exame perante a junta médica da UFG ou a outra credenciada pelo Centro de Seleção, que terá poder de decidir se o candidato necessita ou não [sic] de condições especiais para fazer as provas e opinará, na oportunidade, sobre o grau de necessidade.

2.49. Os candidatos portadores de deficiência, mesmo que não necessitem de condições especiais para realizar as provas, deverão declarar, no ato da inscrição, sua condição de portador de deficiência, indicando o tipo de deficiência.

2.50. A qualquer tempo, se verificada a inscrição que não atenda a todos os requisitos fixados neste Edital, ela será cancelada automaticamente. (UFG, 2010-2 [ingresso 2011-1 Presencial] p. 7, grifo nosso). 
Os itens 2.43 e 2.44 do Excerto 40 evidenciam que a UFG confiou ao laudo médico a incumbência de justificar a necessidade de tempo adicional e a correção diferenciada da Língua Portuguesa aos candidatos surdos. Ao consultar a legislação nacional a esse respeito, identificamos que o artigo 14 do Decreto $n^{\circ}$ 5.626/05 estabelece que cabe as instituições federais de ensino "adotar mecanismos de avaliação coerentes com aprendizado de segunda língua, na correção das provas escritas, valorizando o aspecto semântico e reconhecendo a singularidade linguística manifestada no aspecto formal da Língua Portuguesa” (BRASIL, 2005, p. 29), contudo não consta no referido documento legal a necessidade de uma chancela médica para a fruição desse direito. O mesmo pode ser dito sobre o artigo 27 do Decreto $\mathrm{n}^{\circ}$ 3.298/99 (BRASIL, 1999) ao determinar que, sendo previamente solicitados pelos alunos, as instituições de educação superior devem oferecer, inclusive nos processos seletivos, adaptações de provas e apoios necessários, dentre eles o tempo adicional. Para isso, o referido decreto delibera que "o candidato portador de deficiência que necessitar de tempo adicional para realização das provas deverá requerê-lo, com justificativa acompanhada de parecer emitido por especialista da área de sua deficiência, no prazo estabelecido no edital do concurso.” (BRASIL, 1999). Aparentemente, ser um "especialista da área” não necessariamente equivale a ser um médico, afinal existem especialistas também entre os educadores.

No rastro dessa discussão, cabe ponderar se a ausência da justificativa médica sobre a necessidade da correção diferenciada da Língua Portuguesa ou do tempo adicional (confirmada no indeferimento de solicitações de candidatos baseado no argumento da "documentação incompleta") não foi resultado, talvez, de desconhecimento desse profissional das relações de apropriação da escrita por alunos surdos, aprendizes de português como L2, conteúdos que são, certamente, mais discutidos na formação pedagógica e linguística do que na área médica.

Portanto, é necessário problematizar se um médico estaria apto para deliberar sobre os sujeitos surdos que tenham necessidade de uma análise diferenciada sobre sua produção escrita, quando o domínio da língua escrita e/ou a influência da Libras sobre a primeira decorre de uma série de fatores que não apenas os aspectos biológicos. A abordagem educacional na qual o sujeito surdo foi educado é um desses fatores, afinal, surdos formados no Oralismo não têm a Libras como L1 e, logo, não apresentarão as peculiaridades daqueles que aprenderam a Língua Portuguesa como L2. Idêntica reflexão pode ser feita com surdos pós-linguísticos, ou seja, que perderam a audição após terem adquirido a língua oral e escrita e, muitas vezes, não tiveram contato ou influência da Libras em seu processo de alfabetização. Mas, essas informações estariam sob o domínio clínico? Ou seria mais um resquício do nó que ainda entrelaça a Educação Especial (inclusive, mas não apenas, a educação de surdos) à área da saúde? 
É de conhecimento comum a influência histórica da área médica na Educação Especial, quando as primeiras instituições de ensino voltadas para esse grupo partiram de hospícios, asilos, pavilhões ou alas segregadas e dirigidas por médicos que prescreviam o currículo educacional para serem executados pelos pedagogos, tratados como meros coadjuvantes nesse processo (JANNUZZI, 1992). Na mesma direção, Costa (2009) relata que, durante muito tempo, no início da fundação da primeira escola para surdos do país (o Ines), a produção do currículo e a direção do colégio cabiam aos médicos. Esse retrospecto nos acena a complexidade de romper com as amarras que nos prendem ao discurso clínico e a uma interdependência dos profissionais desse âmbito.

Um movimento no sentido de se distanciar da dependência da área clínica pode ser testemunhado ao avaliar o contexto da SME/SP. Segundo Gonzalez (2013), durante a década de 1990, a SME/SP, por intermédio dos laudos médicos, priorizava a ação da área da saúde para encaminhamento dos alunos às salas de atendimento aos portadores de necessidades especiais. Contudo, essa medida foi alterada por meio de reformulações políticas municipais, em 2004, quando se determinou que o encaminhamento aos serviços de educação especial seria realizado por intermédio de uma avaliação educacional. Essa avaliação educacional seria desenvolvida por “[...] profissionais da escola, prevendo também a participação da família, do supervisor escolar, dos representantes da DRE [...]" (GONZALEZ, 2013, p. 124) e somente se extremamente necessário os profissionais da saúde seriam consultados.

A decisão da SME/SP parece coerente com o disposto no artigo 58 da LDB/96 (BRASIL, 1996), pois os serviços de apoio especializado da Educação Especial são ofertados quando considerados necessários. Isso também denuncia que o sujeito ter uma deficiência, um transtorno global do desenvolvimento, uma alta habilidade ou superdotação não significa diretamente que deva ser assistido por um atendimento educacional especializado. Por fim, não é a condição orgânica que define isso, mas as características individuais e educacionais de cada sujeito, características que deveriam ser avaliadas pela escola e por seus profissionais.

Essa proposta nos inspira a pensar a possibilidade de se desprender da área clínica também os processos seletivos para ingresso na educação superior, pois considerando que a Educação Especial perpassa todos os níveis e modalidades de ensino talvez fosse oportuno, diante da necessidade do parecer de um especialista, que esse ingresso de pessoas surdas na educação superior dialogasse com as etapas anteriores do processo escolar desses alunos, solicitando em lugar de um laudo médico um relatório pedagógico das potencialidades e necessidades educacionais deles. Afinal, um aluno surdo que tenha em sua trajetória escolar dependido de condições diferenciadas durante a realização de suas provas (isso compreende 
não apenas a correção diferenciada de sua produção escrita, bem como a necessidade de tempo adicional, intérprete de Libras ou outras condições) deveria ter essas informações em seus relatórios pedagógicos.

Uma alternativa também seria pensar em uma declaração emitida pelas federações ou associações de surdos, tal como exigido aos candidatos indígenas e quilombolas que pleiteiam vagas a eles reservadas em processos seletivos. Poderiam ser ações para distanciarmos a educação de surdos do enfoque patológico e favorecermos a "reinvenção" da surdez aludida por Lopes (2011). Para a autora, “[...] a surdez como deficiência que marca um corpo determinando sua aprendizagem é inventada através do referente ouvinte, das pedagogias corretivas, da normalização [...]" (LOPES, 2011, p. 8). A autora admite o quão complexa é a tarefa de desvincular a falta de audição do corpo surdo, entendendo que o sentido clínico e terapêutico atribuído à surdez é uma invenção cultural, mas por essa razão permite sua reinvenção sob outro prisma, ou seja, o da diferença.

A princípio, parece-nos contraditório um curso que se propõe formar profissionais bilíngues, ou seja, que supostamente compactua com uma visão política da surdez como diferença, delibere que se deva atestar uma dada condição educacional (no caso, a necessidade de correção diferenciada das questões discursivas) e que essa tarefa seja de competência da área médica. Contudo, essa questão reforça o que já foi apontado por Lopes (2011) ao afiançar que não há garantia nenhuma de que a escola de surdos não reproduzirá resquícios do mesmo modelo clínico terapêutico pautado na normalização do surdo e nas pedagogias corretivas. Vale relembrar que, segundo a autora, “[...] muitas práticas ouvintistas ainda estão em curso nas escolas de surdos. Isso é assim até mesmo naquelas escolas que se dizem acolhedoras da diferença cultural dos surdos e que pretendem desenvolver um currículo surdo." (LOPES, 2011, p. 55-56).

Neste prisma, compactuamos com Skliar (2016) ao defender que não basta deslocar o debate sobre o surdo do grupo da deficiência para o das minorias linguísticas, visto que ambos são discriminados e marginalizados socialmente, sem promover uma ressignificação da surdez capaz de gerar novos mecanismos de participação dos surdos no próprio processo de transformação pedagógica.

Ademais, conforme projetado anteriormente, não podemos perder de vista que a contraditoriedade é uma característica do tempo e espaço social no qual a sociedade moderna está imersa. Estamos definitivamente nesse terreno de ambivalências (BHABHA, 2007), onde não se é nem patológico nem socioantropológico. Somente assim entendemos o Excerto 40, no qual se verifica o reconhecimento da necessidade de mecanismos flexíveis da avaliação escrita 
produzida por surdos, um indício de que nesse curso voltado à formação de professores de Libras será reconhecido que os surdos são bilíngues e biculturais e não sujeitos patológicos que precisam ser normalizados. No entanto, logo no item 2.44 encontramos o laudo médico como documento balizador e em outros itens como o 2.42, 2.43, 2.48 e 2.49 desse excerto, detectamos as terminologias "portadores de deficiência" e "portador de deficiência auditiva", termos bastante arraigados ao modelo médico da surdez há tanto rechaçado por educadores e outros pesquisadores adeptos dos Estudos Surdos (SKLIAR, 1998, 2016), em virtude da carga semântica negativa depositada sobre esses. Isso porque, sob o viés antropológico da surdez, busca-se deslocar a representação de deficiência para a de diferença linguística, inserindo as discussões sobre as pessoas surdas e a língua de sinais dentro dos contextos linguísticos minoritários/minoritarizado, tais como os indígenas e os imigrantes, ou seja, grupos falantes de Língua Portuguesa como L2 (CAVALCANTI, 1999).

Alinhamo-nos também ao apregoado por Prieto (2000, p. 248), ancorada a outros autores, sobre a inadequação da expressão popular "portador" que remete à ideia da pessoa carregar ou portar consigo uma deficiência ou necessidade, quando, na verdade, a necessidade é apresentada ou sentida pelo sujeito. A autora também questiona o resíduo de uma visão clínica impregnada na Educação Especial e reconhece que:

[...] as mudanças de terminologia nem sempre contribuem para deslocar para o meio escolar a responsabilidade por responder adequadamente pelo ensino de todos os educandos. Por outro lado, mudanças de denominação podem contribuir para minimizar efeitos depreciativos que, mais do que revelar a existência de diferenças entre os indivíduos, são, muitas vezes, usados para justificar a permanência de desigualdades de ordem social, econômica, educacional e outras. (PRIETO, 2000, p. 99).

Assim, seguramente, não se trata apenas de mudanças terminológicas, mas atitudinais, embora os termos utilizados possam estar carregados de valores compactuamos com Skliar (2003, p. 125) para quem o politicamente correto também pode se tornar, muitas vezes, um jogo de estratégias discursivas, ou "aquilo de não chame o deficiente de deficiente (ou o negro de negro etc.), mas continue praticando-o, massacrando-o, continue fazendo-o deficiente (ou negro etc.)."

Destarte, pautar-se no aspecto audiológico ao exigir laudos, atestados, exames clínicos e/ou ao se referir ao surdo como "portador de deficiência auditiva" (Excerto 40) se alocam no bojo de uma visão de "corpo danificado", expressão utilizada pela pesquisadora surda Perlin (2016, p. 53). Concordamos com essa autora a fim de enfatizar a necessidade de abandonarmos 
o ponto de vista de normalidade ouvinte para alcançarmos a representação de alteridade cultural ao qual o conceito de identidade surda pertence.

Esse conceito de identidade com o qual compactuamos será retomado no terceiro eixo de análise, explorado na sequência, com a discussão envolvendo a disposição das vagas para surdos, cujo intuito residiu em problematizar o direito de prioridade resguardado aos candidatos surdos no ingresso aos cursos de formação de professores de Libras.

\subsection{A DISPOSIÇÃO DE VAGAS PARA SURDOS}

O Decreto $\mathrm{n}^{0} 5.626 / 05$ dispõe sobre a prioridade do ingresso de pessoas surdas aos cursos de graduação em Letras Libras e Pedagogia bilíngue (BRASIL, 2005), e com a finalidade de acompanhar como essa determinação legal tem se desdobrado na prática dos processos seletivos desenvolvidos pelas Ifes ao longo da última década, o terceiro eixo de análise foi composto de duas categorias e uma subcategoria. A ênfase desse eixo recai sobre a interpretação da prioridade dos candidatos surdos observada nos editais, ora como primazia, ora como reserva de vagas, bem como o cruzamento dessa prioridade com a PAA.

\subsubsection{A interpretação da prioridade dos candidatos surdos}

Após versar sobre as condições de acessibilidade atribuídas aos sujeitos surdos nos cursos de graduação para formação de professores de Libras redirecionamos nosso olhar para o critério de prioridade, temas convergentes. Em nossa leitura, entendemos que nada adiantaria assegurar prioridade na formação de surdos como professores de Libras se, a princípio, o acesso aos processos seletivos estiver de alguma maneira comprometido. Logo, em nosso contexto de pesquisa, acessibilidade e prioridade nos parecem temas interdependentes, os quais não poderíamos negligenciar.

O Decreto $n^{0} 5.626 / 05$ prevê diferentes perfis para a docência da Libras, seja como instrutor ou como professor, os cursos de formação voltados para atender a essa demanda devem obedecer ao dispositivo legal no qual consta que "as pessoas surdas terão prioridade nos cursos de formação previstos [...]" (BRASIL, 2005, p. 28). Cumpre enfatizar que, em nosso entendimento, a prioridade não está sendo atribuída ao caráter assistencialista por acreditar que os surdos sejam deficientes e incapazes, mas como uma estratégia de ação afirmativa para equilibrar as oportunidades de acesso a um nível da educação que tem sido excludente aos que são diferentes (KERSTENETZKY, 2006). 
Segundo Goularte (2014), a expressão “ação afirmativa” surgiu inicialmente na década de 1980 no Brasil e incorporava não apenas os negros e as minorias étnicas e raciais, como também mulheres e pessoas com deficiência, ou seja, grupos que se encontravam de alguma forma discriminados e à margem da sociedade. A luta, de acordo com a autora, concentrou-se na busca da ampliação do ingresso dessas pessoas tanto no mercado de trabalho como no sistema educacional, especialmente na educação superior.

Sendo assim, nesta categoria de análise nos detemos especificamente no que tange à prioridade atribuída aos surdos, ou seja, em como tem sido reportada nos editais. Mas, quão complexa podem ser as diferentes interpretações de uma lei ou decreto? Responder a essa indagação pode nos aproximar daquilo que buscamos, isto é, desvelar a maneira como vem sendo concebida a fruição do direito de prioridade conquistado pelas pessoas surdas. De antemão, embora não incluídos na análise dos dados desta pesquisa documental, em nossa primeira sondagem, tomamos contato com os editais $\mathrm{n}^{0} 1$ e $\mathrm{n}^{\mathrm{o}} 2$ de 2014 da UnB, em que se constou, via retificação do edital original, que os surdos classificados na prova de ingresso para o curso de licenciatura em língua de sinais brasileira ${ }^{100}$ /português como segunda língua teriam como prioridade o resultado da prova objetiva multiplicado por 1,2 (UNIVERSIDADE NACIONAL DE BRASÍLIA, 2014a, 2014b).

No início, também, a partir da leitura do artigo de Franco (2009), localizado por nossa revisão bibliográfica, identificamos que os editais para processos seletivos das vagas destinadas ao curso bilíngue de Pedagogia do Ines, referente aos anos de 2006 e 2007, entenderam como prioridade a “[...] reserva de 50\% para estudantes surdos [...]” (FRANCO, 2009, p. 8). Assim, em concordância com os preceitos da análise de conteúdo de Bardin (1977), previamente à análise dos dados, construímos a hipótese de que a reserva de vagas e a multiplicação do resultado da prova seriam critérios comuns entre as Ifes aqui investigadas, utilizados para se atribuir prioridade de surdos no ingresso aos cursos de formação de professores de Libras.

No entanto, essa hipótese não se materializou integralmente, visto que, em relação à interpretação da prioridade dos candidatos surdos, as medidas que se sobressaíram foram a "reserva de vagas" e o que estamos, provisoriamente, denominando de "primazia", conforme definição encontrada no dicionário online Michaelis (2009):

\footnotetext{
${ }^{100}$ Apesar de a Lei no 10.436/02 (BRASIL, 2002, p. 23) adotar o termo "Língua brasileira de sinais", estamos aqui reproduzindo o nome do curso tal como exibido no edital (UNIVERSIDADE NACIONAL DE BRASÍLIA, 2014a, 2014b).
} 


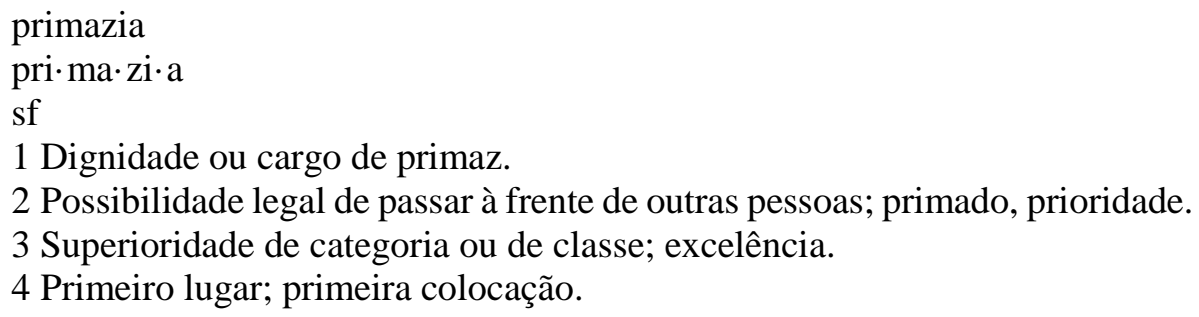

Sob essa ótica, concebemos que a prioridade como primazia é a condição na qual as vagas são, precipuamente, ofertadas para candidatos surdos e, acaso não preenchidas, são direcionadas para candidatos ouvintes, tal como acolhido pela Ufsc em seus processos seletivos, conforme ilustrado no Excerto 41:

\section{Excerto 41}

7. DA APROVAÇÃO E CLASSIFICAÇÃO

[...] 7.3.2 - Em cumprimento ao Decreto 5.626/2005, as vagas do Curso de Licenciatura em Letras Libras (língua brasileira de sinais) são prioritárias para os candidatos surdos. Ou seja, os candidatos ouvintes só serão classificados se as vagas oferecidas não forem preenchidas por candidatos surdos. (UFSC, 2009-1 [ingresso 2009-2 Presencial], p. 6-7; 2010-1 [ingresso 2010-2 Presencial], p. 7, grifo nosso).

Ao longo das edições de processos seletivos da Ufsc, seja na modalidade presencial ou de ensino a distância, os candidatos ouvintes poderiam concorrer apenas às vagas dos cursos de licenciatura, no caso de "restarem vagas" ou "se as vagas oferecidas não [fossem] preenchidas por candidatos surdos" (Excerto 41). Além da Ufsc, somente outras três Ifes adotaram a primazia como critério de prioridade: o Ines em 2006 (sendo um edital para vagas remanescentes), a UFS em 2014-1 e 2014-2 e a UFG em 2015. A redação do Ines pode ser acompanhada na leitura do Excerto 42:

\section{Excerto 42}

O Ministério da Educação, representado pelo Instituto Nacional de Educação de Surdos - Ines, [...] TORNA PÚBLICO o presente Edital para divulgar a abertura do Processo Seletivo para Acesso Discente ao Ensino Superior em 2006 - Concurso Vestibular Ines, para o preenchimento de 9 (nove) vagas, destinadas preferencialmente aos surdos, e, na ausência destes, à ampla concorrência [...] * Na ausência de candidatos surdos, as vagas serão preenchidas pelos demais candidatos. (BRASIL, INES, 2006-1b [ingresso 2006-1 Presencial], p. 25, grifo nosso).

Cabe ressaltar, que o Ines realizou o processo seletivo exclusivamente para candidatos surdos apenas nesse edital destinado a vagas remanescentes, pois nas demais edições foi adotado o sistema de reserva de vagas, a ser discutido em breve. A UFS, por sua vez, recorreu 
ao modelo de interpretação da prioridade nas duas edições aqui analisadas, ambas do ano de 2014 (a primeira para ingresso ainda em 2014 e outra para ingresso em 2015).

No que se refere ao processo seletivo da UFG, dentre os sete editais dessa Ifes apenas o edital de 2015 adotou a primazia aos candidatos surdos, no tocante aos editais de 2010, 2011, 2012 e 2013 foi seguido o sistema de reserva de vagas e nos anteriores nada se reportou quanto à prioridade dos surdos. Aparentemente, em uma análise longitudinal, é possível emitir o parecer de que essa Ifes passou de nenhum critério, para reserva e no seu último edital acolheu o sistema de primazia.

Importa destacar que a primazia foi adotada por quatro Ifes das 24 analisadas, o que consiste no montante de 13 editais de processos seletivos a optarem por tal medida. Como demonstra o Gráfico 5.14, a maioria dos editais que buscava atender o direito de prioridade dos candidatos surdos acolheu a reserva de vagas, sendo 31 editais encontrados nessa categoria, outros dois referiram o atendimento ao Decreto $\mathrm{n}^{\mathrm{o}}$ 5.626/05 (BRASIL, 2005), porém sem discriminaram como isso seria feito; enquanto 34 editais se abstiveram de qualquer indicação às vagas direcionadas para candidatos surdos.

Gráfico 5.14 - Percentual de medidas adotadas pelos editais para atribuir prioridade dos surdos em cursos de formação de professores de Libras entre 2006 a 2015

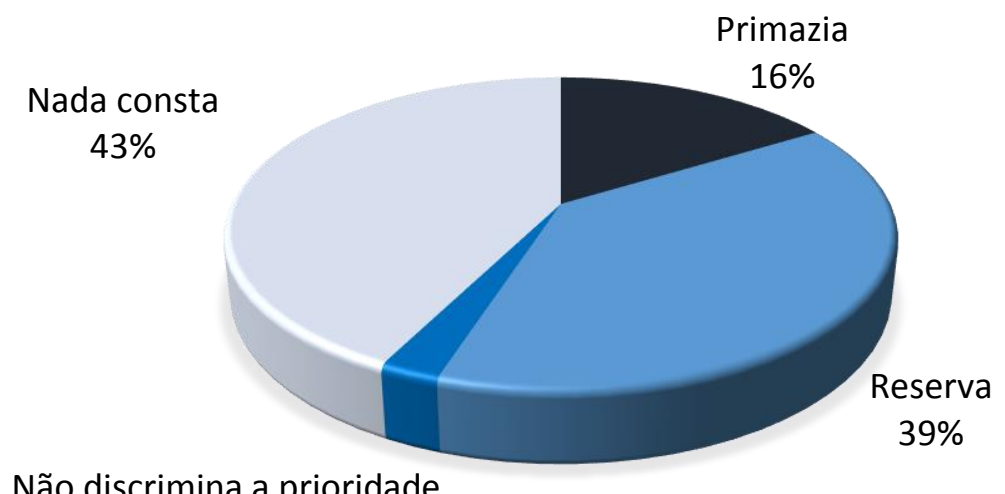

Não discrimina a prioridade

$2 \%$

Chama a atenção o alto percentual de editais, equivalente a 43\%, que se calaram acerca dos artigos $4^{\circ}$ e $5^{\circ}$ do Decreto $n^{\circ} 5.626 / 05$ (BRASIL, 2005), embora fossem cursos enquadrados nas orientações do referido documento legal. Conforme representado no Gráfico 5.15, notamos ainda que, ao longo dos anos, a abstenção dos editais sobre o critério de prioridade dos candidatos surdos (seja como primazia ou reserva de vagas) representa um número considerável, sendo ao todo 34 editais sem prioridade e 46 com prioridade. 
Gráfico 5.15 - Evolução dos editais que acolheram ou não o critério de prioridade dos surdos em cursos de formação de professores de Libras entre 2006 a 2015

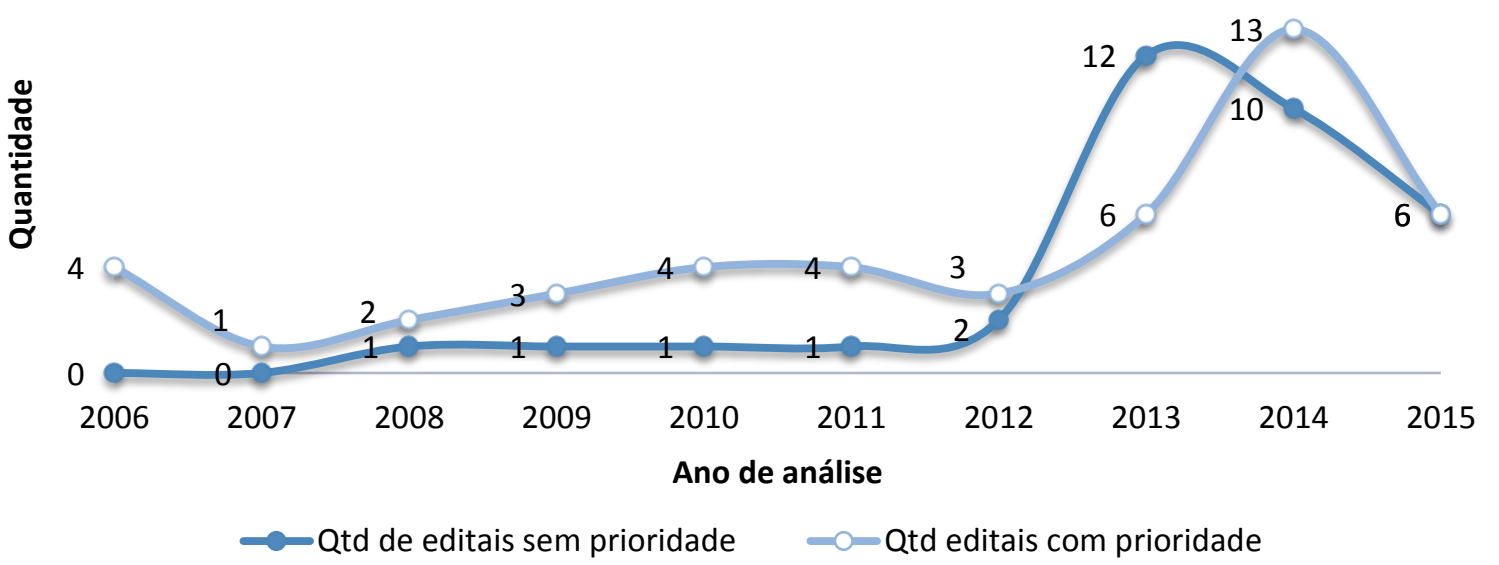

Observa-se que, nos últimos anos, o contraste se acentua em 2013, quando o número de editais sem prioridade ultrapassa significativamente o número de editais com prioridade, no ano seguinte verificamos um leve decréscimo, permitindo um quadro com mais editais que contemplam o critério de prioridade e, em 2015, um resultado igualado.

Ademais, ao verificar o Gráfico 5.15 seria possível depreender que a escolha pela inexistência da indicação à prioridade não se trata de um lapso cometido pelas instituições em suas primeiras edições o qual seria ao longo do tempo reparado. Como exemplo dessa afirmação, salientamos a UFPA que, desde seu primeiro processo seletivo em 2010 até o último em 2014, deixou de realizar qualquer menção em seu edital sobre o critério de prioridade dos surdos, isto nos induz à conclusão de que, propositalmente, não houve tratamento diferenciado a esse público nesse aspecto.

Acreditamos que o acesso a tais cursos reverbera em inúmeras questões, muito além da formação de surdos como professores de Libras. O próprio acesso das pessoas surdas à educação superior deve ser considerado, pois, em concordância com Lopes (2011), o ingresso desse grupo de pessoas nas universidades potencializa a militância surda que se qualifica tornando possível a outros surdos adentrarem no espaço acadêmico, até pouco tempo quase inabitado por eles.

Some-se a isso, a contribuição da presença dos surdos nas universidades para o avanço na produção e divulgação dos Estudos Surdos. Ao narrar um breve histórico da criação do Nuppes, a autora descreve que, em meados da década de 1990, houve uma expansão nos estudos envolvendo a educação de surdos e a língua de sinais. Nesse processo, Lopes (2011, p. 34-35) afirma que a presença de professores surdos foi essencial "[...] para servirem de 'modelo 
cultural' para outros surdos [...]" como também para demonstrarem formas diferentes de se trabalhar com esses alunos. De acordo com Lopes (2011, p. 35):

\begin{abstract}
Nesse movimento, foi muito importante a entrada de pesquisadores surdos na universidade. Com a presença marcante dos surdos como pesquisadores e como sujeitos participantes de fóruns de discussão e de pesquisas na área de Educação no espaço da academia, aconteceram muitas mudanças. Além de possibilitar a formação de professores e de pesquisadores surdos, o Nuppes também gerava, na comunidade científica, na comunidade surda e naqueles que direta ou indiretamente se relacionavam com surdos, outras representações e outras verdades sobre esses sujeitos.
\end{abstract}

Notamos com isso que o reconhecimento de um direito garantido por lei aos surdos, no caso, em questão, a prioridade para ingresso nos cursos para formação de professores de Libras, é resultado de discussões promovidas por estudiosos e pesquisadores da área que vislumbraram razões educacionais, culturais, identitárias e políticas para defenderem um tratamento diferenciado.

Poderíamos aqui nos prolongar em justificar a questão prioritária como um direito aos surdos, contudo nos associamos a Bobbio (1992) para quem o fundamento absoluto não pode ser alcançado. Para esse autor, trata-se de uma ilusão acreditar que "[...] de tanto acumular e elaborar razões e argumentos - terminaremos por encontrar a razão e o argumento irresistível, ao qual ninguém poderá recusar a própria adesão.” (BOBBIO, 1992, p. 16).

Os direitos são, conforme Bobbio (1992), estabelecidos dentro de um tempo e de uma cultura, logo não existiriam argumentos ou fundamentos absolutos, ou seja, que seriam universalmente aceitos sem discordância. Segundo o autor, as justificativas poderiam ser refutadas, pois as pessoas apresentam diferentes pontos de vista, inclusive para os direitos aparentemente mais autossuficientes como, por exemplo, o direito à liberdade. Utilizando o exemplo dado pelo autor, se tomarmos o direito à liberdade no período da escravidão ${ }^{101}$ este seria facilmente discutido, pois infringia o direito do "senhor" a escravizar e torturar aquele que julgava ser sua "posse" (BOBBIO, 1992).

O exemplo ministrado serve para aludir que nenhum direito é absoluto e que buscar uma justificativa indiscutível seria um processo infrutífero. Para Bobbio (1992), os direitos humanos não são direitos conquistados pelo simples fato de que somos humanos, mas são direitos históricos que refletem momentos vivenciados por nossa sociedade, direitos conquistados como resultados de uma série de movimentos sociais, históricos e políticos. É assim o direito de

${ }^{101}$ Reconhecemos que ainda há regime de escravidão sendo ilegalmente praticado em tempos atuais, mas nossa referência se reporta ao período em que essa ocorria oficialmente. 
prioridade atribuído aos surdos, consequência de uma intensa trajetória de lutas empreendidas pelas comunidades de pessoas surdas no país e, negligenciá-lo seria, mais uma vez, silenciar os surdos na história.

Dito de outra forma, a prioridade não precisa ser justificada, pois isso já foi feito anteriormente quando aprovada por intermédio do Decreto $\mathrm{n}^{\circ}$ 5.626/05 (BRASIL, 2005). Em consonância com Bobbio (1992), o que precisamos é garantir a exequibilidade desses direitos já reconhecidos pelo ordenamento jurídico, uma luta que, conforme exorta o aludido autor, não é menos laboriosa que a primeira. Em síntese, parafraseando Bobbio (1992, p. 23-24, grifo do autor): “O problema fundamental em relação aos direitos do homem, hoje, não é tanto o de justificá-los, mas o de protegê-los. Trata-se de um problema não filosófico, mas político.”

Diante do exposto, retomaremos o debate referente aos processos seletivos que reconheceram a prioridade conquistada pelas pessoas surdas e garantiram de alguma forma, em seus editais, a fruição desse direito. Como pode ser acompanhado no Gráfico 5.14, houve dois editais que citaram a prioridade dos surdos, mas omitiram como seria atribuída e ambos foram elaborados pela UFC nos anos de 2014 e 2015, com a redação que segue no Excerto 43.

\section{Excerto 43}

DOS CRITÉRIOS DE SELEÇÃO

Art. $2^{\circ}$ Em cumprimento ao Decreto $\mathbf{n}^{\circ} \mathbf{5 . 6 2 6}$, de 22 de dezembro de 2005, da Presidência da República, para cada uma das Classes de Concorrências citadas no Art. $1^{\circ}$, será dada prioridade às pessoas surdas, com a devida comprovação documental. (UFC, 2014-1 [ingresso 2014-2 Presencial], p. 2; 2015-1 [ingresso 2015-2 Presencial], p. 1, grifo nosso).

Conforme o Excerto 43, a UFC determina que mediante comprovação documental será dada a prioridade dos candidatos surdos, porém, sem mais esclarecimentos de sua interpretação sobre o critério de "prioridade", o que conforme vimos demonstrando representa um conceito com diversas leituras. Possivelmente, em virtude do processo seletivo ter sido realizado com base nas notas do Enem, não conseguimos identificar se tal prioridade foi efetivada mediante um bônus na nota, um critério de desempate, a primazia ou a reserva de vagas. Ao consultarmos a lista do resultado final dos candidatos desse processo seletivo não localizamos as notas, nem a identificação da prioridade, tampouco a relação dos pretendentes surdos às vagas, somente a divisão por categorias da PAA.

Cabe resgatar que, de acordo com o artigo 42 do Decreto n 3.298/99, a divulgação do resultado final de concursos públicos nos quais haja candidatos com deficiência deve ocorrer em duas listas, uma lista geral com a pontuação de todos os candidatos e outra destinada à 
pontuação dos candidatos com deficiência (BRASIL, 1999). Entretanto, a divulgação de duas listas esteve longe de ter sido adotada pela UFC, bem como da maioria de Ifes abrangidas nesta pesquisa, algumas inclusive só disponibilizavam o resultado mediante consulta individual do candidato no sistema com o fornecimento do Cadastro de Pessoas Físicas (CPF), isto nos impediu de ter acesso a dados mais precisos acerca da quantidade de alunos surdos aprovados e classificados.

A desobediência do artigo 42 do Decreto $n^{0} 3.298 / 99$ (BRASIL, 1999), referente à divulgação dos resultados de concursos envolvendo candidatos com deficiência, e dos artigos $4^{\circ}$ e $5^{\circ}$ do Decreto $n^{\circ} 5.626 / 05$ (BRASIL, 2005), que dispõem sobre a prioridade dos surdos no acesso aos cursos de formação para docência da Libras, foi vislumbrada em diversos processos seletivos e nos induz a vários questionamentos, mas o principal deles é: existe alguma fiscalização sendo feita com relação a esses processos seletivos?

Decerto, a análise dos editais elencados nesta pesquisa demonstrou as dificuldades de um expressivo número de Ifes de atender determinações legais promulgadas há mais de dez anos, sobretudo as concernentes à prioridade outorgada aos surdos no ingresso aos cursos de educação superior em Letras Libras e Pedagogia bilíngue.

Isso posto, compactuamos com Prieto (2000, p. 57), quando a autora embora sem abordar os referidos decretos expõe que, "muitas vezes, o conteúdo dos documentos oficiais é formulado com pouca precisão e/ou clareza, o que permite formas diversas de interpretação, podendo se constituir como um obstáculo para a adequada implantação e avaliação de políticas sociais." Assim, ao determinar a prioridade, mas não prestar esclarecimentos sobre o que se entende com ela e como implementá-la, o Decreto $n^{\circ}$ 5.626/05 permite inúmeras interpretações para esse conceito, seja como reserva de vagas, primazia ou ainda como ausência de qualquer ação nesse âmbito, tal como constatamos em inúmeros editais. Na mesma direção, por sua vez, a indefinição de critérios precisos e explícitos dificulta a avaliação de seu cumprimento.

Vale salientar que, inclusive as Ifes responsáveis pelos 39\% de editais que interpretaram a prioridade como reserva de vagas, carecem de maior esclarecimento e acompanhamento do poder público, pois esse percentual adotado por uma ou outra instituição também apresentou dissenso, com cotas que variavam de $10 \%$ até $80 \%$ das vagas, conforme ilustra o Gráfico 5.16: 
Gráfico 5.16 - Percentual de reserva de vagas adotado pelos editais de processos seletivos para cursos de formação de professores de Libras entre 2006 a 2015

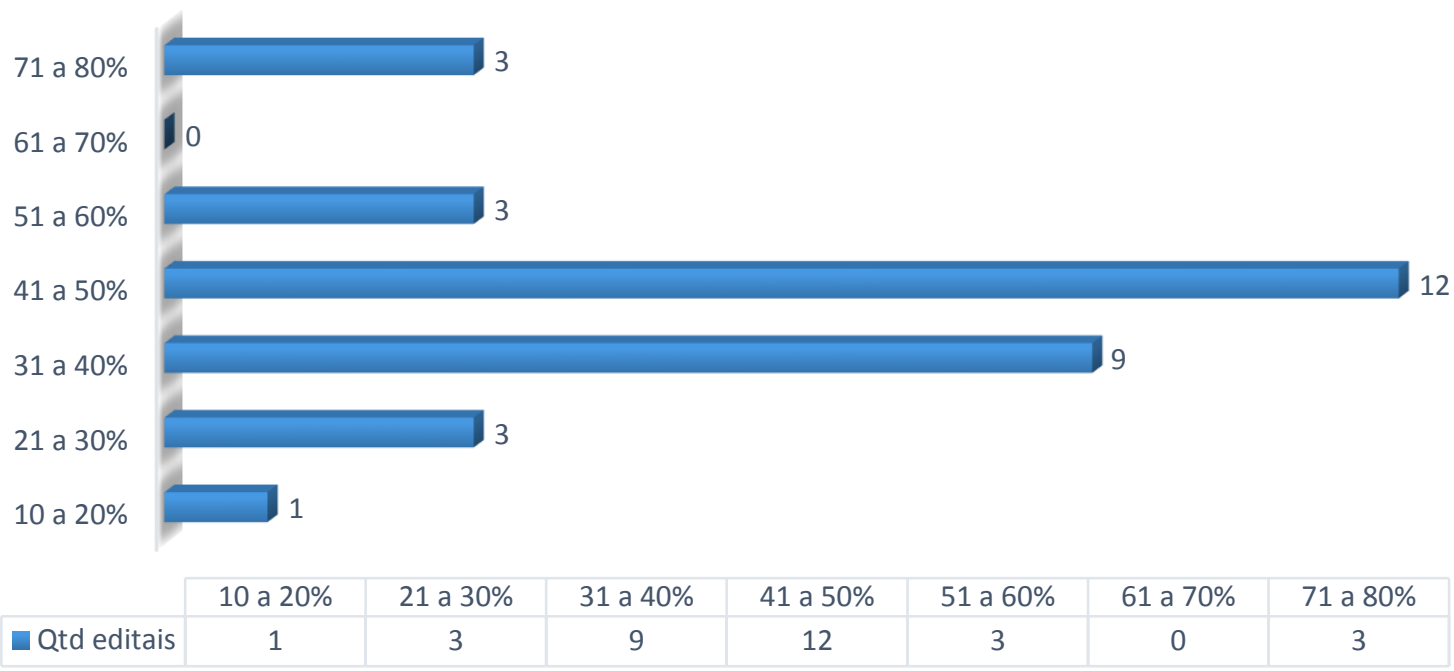

A conferência do Gráfico 5.16 demonstra que entre os processos seletivos que optaram pela reserva de vagas para surdos no período de 2006 a 2015, visualizamos maior concentração de editais na faixa de 41 a 50\% (equivalente a 12 editais) e de 31 a $40 \%$ (igual a 9 editais). Logo, esses dados revelam que, para a maioria desses editais, a reserva de 30 a $50 \%$ das vagas atenderia a "prioridade" estabelecida pelo Decreto $n^{0}$ 5.626/05 (BRASIL, 2005). Contudo, verificamos que há uma enorme discrepância entre o edital que considerou a reserva de vagas para surdos em 10\%, ao passo que outros chegaram a ponderar o limiar entre 71 a $80 \%$.

Aparentemente, julgar o que seja "prioridade" pode representar uma tarefa mais árdua do que concebida a princípio. Com intuito de dirimir essa dúvida conceitual, sondamos o dicionário Aurélio de Língua Portuguesa:

prioridade. [De prior+ $-i+-d a d e$.] S.f. 1. Qualidade do que está em primeiro lugar, ou do que aparece primeiro; primazia. 2. Preferência dada a alguém relativamente ao tempo de realização de seu direito, com preterição do de outros; primazia. 3. Qualidade duma coisa que é posta em primeiro lugar, numa série ou ordem. (FERREIRA, 1986, p. 1393, grifo do autor).

Complementamos a busca, consultando ainda um dicionário mais atual como o Michaelis online:

prioridade pri.o.ri.da.de sf (lat med prioritate) 1 Qualidade ou estado de primeiro; antecedência no tempo. 2 Precedência no tempo ou no lugar; primazia, preferência. 3 Direito de falar primeiro ou de ser atendido em primeiro lugar. 4 Preferência de fabricação, fornecimento, transporte etc. decretada para produtos ou materiais 
escassos em tempos de emergência. 5 Inform Importância de um dispositivo ou rotina de software, num sistema de computador. (MICHAELIS, 2009, grifo do autor).

Em ambas as definições, seja do dicionário Aurélio (FERREIRA, 1986) ou Michaelis (2009), notamos que o conceito de prioridade está mais aproximado ao de primazia, isso é, da qualidade ou direito de estar em primeiro lugar diante de outrem. No rastro dessa reflexão, cabe questionar se a reserva de vagas atenderia ao propósito de prioridade no âmbito legal, resguardando aos surdos a conquista desse direito. Com base nessa dúvida, direcionamos nosso olhar para o resultado dos processos seletivos cotejando o ingresso dos surdos via critério de reserva e de primazia, temática a ser discutida na sequência, por meio da subcategoria referente ao preenchimento das vagas destinadas aos candidatos surdos.

\subsubsection{Preenchimento das vagas destinadas aos candidatos surdos}

Para a análise desta subcategoria é preciso enfatizar que, inicialmente, nosso objetivo era abordar apenas os editais de vestibulares e, conforme realizávamos a busca e nos deparávamos com outros documentos pertinentes aos processos seletivos complementamos nosso corpus. No entanto, não foram todas as Ifes (nem todos os processos seletivos) que divulgaram as listas de candidatos inscritos e aprovados, fato que nos impediu de realizar uma leitura desse procedimento em todos os contextos. Desse modo, relataremos apenas as Ifes que localizamos os dados de inscrição e aprovação, dentre as quais: a UFS, a UFC, a UFG, o IFG, a Ufsc, o Ines, a Unifap, a UFMA, a UFPE, a UFPB, a UFT, a UFPI, a Ufac, a Ufal e a UFRN.

Sendo apenas quatro Ifes que se dedicaram a admitir a prioridade como primazia e no único edital do Ines, de 2006, que realizou tal orientação, não foram localizadas informações relacionadas aos alunos inscritos e aprovados, pois por ser antigo, como já alertado no capítulo metodológico, estava disponível somente no DOU. Concernente aos dois processos seletivos da UFS, encontramos tão somente o resultado da classificação final, sem informações sobre os surdos inscritos, ausentes e reprovados.

No que tange ao vestibular da UFS do primeiro semestre de 2014, para ingresso no referido semestre, analisamos que com o critério de primazia, no primeiro edital de 2014 dentre as 30 vagas disponibilizadas, em uma concorrência de 15,8 candidatos por vaga, 21 foram preenchidas por candidatos surdos. Entretanto, na edição seguinte do processo seletivo da UFS, em uma concorrência menor de 7,3 candidatos por vaga, dentre as 30 vagas disponibilizadas foram admitidos apenas seis participantes surdos. Considerando que não houve mudanças 
substanciais no edital, nem nos recursos de acessibilidade para surdos (ambas as provas foram projetadas em Libras e seu conteúdo envolvia textos da área da educação de surdos complementados com recursos visuais) e que apenas três candidatos foram eliminados do processo seletivo, descartamos a hipótese de que os surdos não foram admitidos por terem sido reprovados. Logo aventamos que, provavelmente, tenha ocorrido uma baixa adesão de candidatos surdos na segunda edição do processo seletivo da UFS, o que acarretou um universo menor de surdos classificados, embora não possamos afirmar com convicção, pois esse dado não foi disponibilizado.

Apesar de não termos localizado a lista com os candidatos surdos aprovados pela Ufsc, por intermédio das informações apresentadas por Quadros e Stumpf (2014, p. 459), tomamos conhecimento de que as vagas para os cursos de licenciatura em Letras Libras ofertados na modalidade a distância dessa Ifes em 2006 e 2008 foram, majoritariamente, contempladas aos surdos, sendo apenas 53 vagas, das 500 oferecidas, preenchidas por candidatos ouvintes, e considerando que em cinco dos oito polos de ensino da Ufsc nenhum candidato ouvinte foi admitido para o curso de licenciatura. Sendo o Rio de Janeiro um desses polos onde nenhum ouvinte foi admitido, Franco (2009, p. 24) questiona: "Não seria o caso de estabelecer cotas para ouvintes, como ocorre nas universidades ou mesmo no próprio curso de Pedagogia do Ines?" E, de certo modo, não podemos negar a razão de sua interrogação, uma vez que entendemos o movimento afirmativo das comunidades surdas para a docência da Libras, mas também admitimos o direito de as pessoas ouvintes não terem seu ingresso a um curso de educação superior recusado em virtude dos mesmos parâmetros audiológicos que os surdos lutam para serem abolidos.

A despeito disso, confirmamos a eficácia do sistema de primazia para a promoção do ingresso de surdos aos cursos aqui investigados. Pelo critério de primazia, enquanto os números do processo seletivo de 2006 da Ufsc, divulgados por Quadros e Stumpf (2014), conduzem ao percentual de $89,4 \%$ das vagas preenchidas por surdos, no caso do processo seletivo de 2014 do IFG em que se adotou a reserva de vagas conferimos que dos 25 candidatos surdos inscritos para as nove vagas reservadas, apenas um foi aprovado, ou seja, 97\% das vagas do curso de Pedagogia bilíngue do IFG foram preenchidas por ouvintes.

Fato similar ocorreu na UFG, em 2010, quando foram reservadas 15 vagas para surdos. Embora não tenham sido listados os candidatos surdos inscritos, por meio da nossa análise da lista de candidatos surdos solicitantes da correção diferenciada da prova discursiva e que tiveram sua inscrição deferida, constatamos 19 candidatos surdos. Contudo, no resultado final, apenas 13 deles foram aprovados e classificados. Resultado semelhante foi observado no 
processo seletivo de 2013, desenvolvido pela referida instituição, quando das 15 vagas reservadas para surdos apenas 13 candidatos foram selecionados. Diferente do vestibular de 2010 no qual houve um número maior de candidatos surdos do que de vagas reservadas, a análise de 2015, ano em que a Ifes passou a adotar o critério de primazia, demonstrou que havia apenas cinco inscrições homologadas para surdos, sendo dentre elas, três aprovadas. As vagas remanescentes foram direcionadas para os candidatos interessados e cadastrados no Sisu, que foram aceitos apesar de não terem passado pelas provas do processo seletivo, tal como os candidatos surdos.

Seria discutível a decisão de submeter apenas as vagas destinadas aos candidatos surdos a uma prova, especialmente quando o artigo 42 do Decreto $\mathrm{n}^{\circ} 3.298 / 99$ determina que a avaliação, os critérios de aprovação, o conteúdo, o horário e local de aplicação das provas em concursos devem seguir o princípio de igualdade entre pessoas com deficiência e os demais candidatos (BRASIL, 1999). Entretanto, sem a pretensão de nos desviarmos de nosso foco, ou seja, sobre os indicadores de inscritos e aprovados que abordamos nesta subcategoria, é possível inferir que os documentos analisados nos revelam que a UFG teve dificuldades para realizar o preenchimento integral das vagas destinadas aos candidatos surdos.

Outra Ifes que não conseguiu completar a reserva de vagas feita para candidatos surdos foi a Unifap que direcionou 18 das 30 vagas para estudantes surdos, porém na listagem dos aprovados e classificados havia apenas um aluno surdo. Nesse contexto, também descartamos a hipótese de uma baixa procura dos surdos, pois ao verificarmos as inscrições de surdos homologadas notamos que havia ao menos 20 inscrições deferidas. É válido mencionar que inclusive os candidatos ouvintes inscritos nesse processo seletivo para o curso de Letras Libras da referida instituição não alcançaram aprovação, pois foi necessário remanejar 17 candidatos de outros cursos para completar a turma.

A UFMA passou por situação parecida em 2014, ao reservar dez dentre as 40 vagas para surdos e preencher apenas duas delas, ainda que na lista de requisição de atendimento diferenciado tenhamos encontrado 26 participantes que solicitaram a presença de intérprete de Libras, que nos permite descartar a hipótese da ausência de candidatos surdos. Por sua vez, a UFPE quase atingiu os $70 \%$ de vagas reservadas para surdos, equivalente a 22 das 30 vagas abertas em seu processo seletivo do ano de 2014. Houve 29 surdos inscritos, porém dois se ausentaram, três foram eliminados na prova objetiva de Libras e outros três na redação, sendo aprovados e classificados 21 participantes surdos. Ao consultarmos as notas divulgadas nos resultados finais observamos que a maior nota foi de um participante ouvinte com 10,0, sendo a menor nota entre os aprovados ouvintes a de 6,25. Entre os surdos, a maior nota foi 9,75 e a 
menor 3,25, serve para indicar que, sem a reserva de vagas, muitos surdos poderiam não ter sido admitidos ${ }^{102}$.

Diferentemente do que ocorreu com a UFG, IFG, Unifap, UFMA e UFPE, em que houve um número de candidatos surdos superior ao de vagas ofertadas, ao averiguarmos os processos seletivos da UFPB de 2010, 2011 e 2013 (anos em que constavam dados suficientes para emitir uma análise), observamos que a falta de preenchimento da reserva de vagas para surdos decorreu, em 2010, da baixa procura por parte desses candidatos.

Em 2010, a UFPB destinou 158 vagas (dentre as 210) para candidatos surdos (sendo as demais reservadas para professores), porém apenas 81 surdos se inscreveram. No ano seguinte, ao invés de $75 \%$ das vagas reservadas para surdos, a UFPB concedeu $48 \%$, reduzindo assim a cota destinada a esse grupo. Para as 48 vagas dedicadas aos surdos em 2011, foram recebidas 95 inscrições de pessoas surdas. Em 2013, a instituição apostou em designar 52\% das vagas para surdos, o equivalente a 91 vagas, e obteve 102 participantes surdos inscritos. Como a UFPB não liberou o resultado de seu processo seletivo, não foi possível afirmar se com esse número de inscritos eles conseguiram preencher integralmente as vagas reservadas em $2011 \mathrm{e}$ 2013, uma vez que seria preciso contabilizar candidatos ausentes e desclassificados. Todavia, ao analisar que, em alguns de seus polos de educação, houve uma procura de um ou menos candidatos por vaga, já foi possível inferir que, na situação dessa instituição, a dificuldade pode ter sido devido à baixa adesão dos candidatos surdos ${ }^{103}$.

Conforme nossos dados, observamos que o Ines também enfrentou desafios no preenchimento da reserva de vagas de $50 \%$ feita para candidatos surdos ao curso de Pedagogia bilíngue. Nos arquivos do edital de 2013 notamos que sobretudo na turma do período matutino na qual foram ofertadas 15 vagas, houve apenas nove surdos inscritos, todos aprovados ao cabo do referido processo seletivo. O período noturno apresentou menos dificuldades de preencher a cota para surdos, pois teve 18 inscritos e 15 aprovados. Além disso, tendo em vista que, em 2006, foi aberto um edital para vagas remanescentes no qual constou que as vagas eram preferencialmente para surdos, infere-se que a dificuldade de inscrição por parte de candidatos surdos já havia sido presenciada anteriormente pela instituição. Apesar de não ser possível

102 Observamos as notas dos resultados finais quando tais informações foram divulgadas abertamente, possibilitando o acesso a elas. Conforme mencionado, algumas instituições não o fizeram. O parâmetro de comparação entre as notas dos candidatos surdos e ouvintes foi realizada por Franco (2009), ao analisar os processos seletivos do curso de Pedagogia bilíngue do Ines.

${ }^{103}$ Cumpre destacar que a UFPB teve suas vagas distribuídas em vários polos que, analisados individualmente, permitiram-nos entrever a dificuldade de adesão de candidatos surdos. Em 2010, no polo de Taperoá nenhum candidato surdo se inscreveu para as 30 vagas reservadas, nos demais polos todas as vagas ofertadas para esse público foram maiores do que o número de inscrições. Em 2013, também houve polos como Coremas e Duas Estradas que ofertaram 13 vagas para surdos, mas tiveram, respectivamente, sete e dois inscritos nessa categoria. 
conferir o número de surdos inscritos do processo seletivo de 2014, verificamos que o Ines lidou novamente com desafios para o preenchimento da reserva destinada a surdos, pois a partir dos resultados, no período da manhã, das 15 vagas apenas duas foram preenchidas por esse público, e no período noturno 13 candidatos foram aprovados, tendo faltado dois para o preenchimento integral da cota.

Franco (2009) pesquisou os processos seletivos do Ines realizados entre 2006 e 2007, e afirma ter havido desde as primeiras edições dificuldades por parte dessa Ifes de preencher as cotas destinadas aos surdos:

[Em 2006] Das sessenta vagas oferecidas, apenas quatorze foram preenchidas por estudantes surdos, sendo que desse universo quatro trancaram ou abandonaram o curso numa proporção correspondente de sete estudantes ouvintes.

Essa mesma realidade se repetiu no segundo vestibular, em 2007. Selecionando candidatos já para o recém-aprovado curso de Pedagogia e com o acúmulo da experiência anterior, o curso, mais divulgado dentre a comunidade surda, passa a contar com um quantitativo de quatro alunos surdos no turno da tarde contra vinte e seis ouvintes. No período noturno, essa realidade se apresenta com oito estudantes surdos contra vinte e dois alunos ouvintes. (FRANCO, 2009, p. 23).

Diante de seus dados, a autora levanta inúmeros questionamentos acerca dos motivos que levaram curso de Pedagogia bilíngue do Ines ter sido majoritariamente composto por ouvintes. Para Franco (2009, p. 23):

Os motivos podem ser vários, reunidos ou isolados. O ensino formal -
sobretudo no que diz respeito ao ensino médio, e mesmo às classes de pré-
vestibular oferecidas pelo Ines aos estudantes surdos - não estaria preparando
os estudantes, ainda que selecionados, por um processo, tudo indica, atípico
de vestibular? Por outro lado, poder-se-ia relacionar essa baixa procura ao fato
de que aos surdos não interessaria o curso de Pedagogia, usualmente também
discriminado por estudantes ouvintes?

As reflexões realizadas pela autora são coerentes, tendo em vista que tal como já apontado por Silva (2005) e Daroque e Queiroz (2013), sabemos que a educação básica ofertada para surdos é repleta de infortúnios causados pelas mais variadas razões como, por exemplo, o despreparo dos docentes, a ausência de intérpretes de Libras, a falta de materiais didáticos adequados para a educação bilíngue dos surdos etc.

Do mesmo modo, é inegável que presenciamos um alto desinteresse pelo curso de Pedagogia nos últimos anos, devido à baixa remuneração em face das diversas exigências feitas a esse profissional. De acordo com Gatti e Barreto (2009), baseados em estudos da sociologia 
do trabalho, a valorização social de uma profissão reflete diretamente nas condições de trabalho, salário e carreira e, evidentemente, carreiras e salários pouco atrativos não despertam o interesse das novas gerações, em especial, dos jovens que se consideram em condições de procurar melhores oportunidades em outras atividades. Em síntese, “[...] para certo conjunto de jovens o magistério não é uma carreira que estimula sua procura.” (GATTI; BARRETO, 2009, p. 240).

Em 2014, em conversa informal estabelecida com a $\operatorname{Prof}^{\mathrm{a}} \operatorname{Dr}^{\mathrm{a}}$ Wilma Favorito e a Prof ${ }^{\mathrm{a}}$ Dr $^{\mathrm{a}}$ Janete Mandelblatt, ambas docentes do departamento de ensino superior, no qual se insere o curso de Pedagogia bilíngue do Ines, ao serem indagadas sobre o desafio de preencher integralmente as vagas reservadas aos surdos, foi reportada que uma possível justificativa seja a concomitância do referido instituto como polo do curso de Letras Libras ofertado na modalidade EaD pela Ufsc (informação verbal ${ }^{104}$ ). Logo, nessa mesma Ifes são promovidos aos surdos dois cursos de graduação na área da formação da docência da Libras, sendo em ambos adotada a prioridade dos participantes surdos (no curso de Pedagogia bilíngue através da reserva de vagas e no curso de Letras Libras o critério de primazia).

De fato, o curso de Letras Libras também é uma carreira docente, tal como o curso de Pedagogia bilíngue. Contudo, cumpre salientar que os egressos desses cursos podem atuar em diferentes etapas da educação básica. De acordo com o Decreto ${ }^{\circ} 5.626 / 05$, profissionais do curso de Pedagogia bilíngue atuam na educação infantil e anos iniciais do ensino fundamental, já com o curso de Letras Libras podem atuar na docência da Libras nos anos finais do ensino fundamental, no ensino médio e inclusive na educação superior. Essa constatação pode influenciar a decisão dos estudantes surdos e ouvintes na escolha do curso, pois, embora não tenhamos os valores salariais de docentes na educação superior, a respeito da educação básica, conforme dados apresentados por Gatti e Barreto (2009), extraídos da Pesquisa Nacional por Amostra de Domicílios realizada em 2006 no país, é possível verificar que a média salarial dos docentes brasileiros é menor na educação infantil, cerca de $\mathrm{R} \$ 661,00$ e aumenta gradativamente conforme as etapas, sendo $\mathrm{R} \$ 873,00$ no ensino fundamental e $\mathrm{R} \$ 1.390,00$ no ensino médio.

Essa suspeita se reforça ao analisar os resultados da dissertação da pesquisadora surda Sarturi (2013), realizada com 37 professores de Libras formados pelo curso de Letras Libras da Ufsc pelo Polo de Santa Maria, turma de 2006, em que a autora verificou que a maioria dos

\footnotetext{
${ }^{104}$ Informação fornecida pela $\operatorname{Prof}^{\mathrm{a}} \mathrm{Dr}^{\mathrm{a}}$ Wilma Favorito e a Prof ${ }^{\mathrm{a}} \operatorname{Dr}^{\mathrm{a}}$ Janete Mandelblatt, no Rio de Janeiro, em
} 2014. 
participantes estavam alocados ministrando aula de Libras como L2 para ouvintes em IES públicas e privadas.

Portanto, é possível que as docentes e pesquisadoras do Ines tenham razão ao desconfiarem da concorrência com o curso de Letras Libras, uma vez que tal curso oferece um nicho de atuação profissional com oportunidades de salário, carreira e status mais atrativos se comparados à educação infantil e anos iniciais do ensino fundamental, segmentos do egresso do curso de Pedagogia bilíngue.

Outra hipótese ventilada por Franco (2009) para a maior adesão de candidatos ouvintes ao curso de Pedagogia bilíngue do Ines seria a falta de divulgação em meio a comunidade surda acerca do curso na época recém-criado pelo Ines, mas logo descartada ao observar que o curso de Letras Libras ofertado pela Ufsc, tendo o Ines como Polo, foi quase integralmente preenchido por surdos, o que também "[...] desautoriza, pelo menos parcialmente, de um lado, a noção de que não haveria surdos devidamente preparados para um exame de vestibular [...]" (FRANCO, 2009, p. 24). Segundo a autora, houve inicialmente a suspeita de que os ouvintes teriam preenchido a maioria das vagas por terem apresentado melhor desempenho nas avaliações, incluindo na prova de domínio em Libras. No entanto, os resultados finais do vestibular de 2007 demonstraram que as maiores notas foram conquistadas por candidatos surdos, ao passo que a menor nota final foi atribuída a um candidato ouvinte (FRANCO, 2009).

Assim, corroboramos Franco (2009), quando afirma que pode não ter ocorrido uma senão várias razões para dificuldade de preenchimento da reserva de vagas para surdos, tal como concordamos com as professoras e pesquisadoras do Ines quando referem que a concorrência com o curso de Letras Libras no mesmo espaço possa ter absorvido a grande demanda de surdos em idade para cursar uma graduação. Nesse último aspecto, faz-se mister considerar que o Rio de Janeiro, entre 2005 e 2015, foi palco de 18 dos 80 editais de processos seletivos de cursos de graduação para formação de docentes da Libras levantados nesta pesquisa. Isso porque, além do Ines e da Ufsc, a UFRJ também oferta o curso de Letras Libras desde 2013. Em que pese o Rio de Janeiro ser um grande polo urbano, cabe lembrar que São Paulo é um estado ainda mais populoso e, nesse período, teve apenas dois processos seletivos para o curso de Letras Libras, ambos promovidos pela Ufsc por meio da modalidade EaD.

Contudo, seriam justificativas aceitáveis se, o curso de Pedagogia do Ines fosse o único dentre as Ifes optantes pela reserva de vagas a se deparar com o desafio de preencher sua cota para surdos. Ao invés disso, os dados da presente pesquisa revelam que não apenas o Ines nem somente o curso de Pedagogia bilíngue tiveram essa dificuldade. Apesar dos desafios para a adesão de candidatos surdos, diferente da UFPB, o Ines manteve inalterado o percentual 
atribuído à reserva de vagas para surdos, sendo desde sua primeira edição mantido o compromisso de resguardar metade das vagas para esse público. É válido esclarecer ainda que nem todas as Ifes investigadas nesta pesquisa deixaram de preencher integralmente as vagas ofertadas para participantes surdos em seus processos seletivos, e aquelas que o fizeram pertencem às regiões Norte e Nordeste do país.

Assim, em 2015, a UFT também adotou o sistema de reserva de vagas direcionando 18 lugares para os candidatos surdos e 12 para ouvintes. Com 86 inscritos para as vagas reservadas aos surdos, apenas 14 deles tiveram a inscrição homologada para concorrerem à cota de $60 \%$. Como habitual nesses casos, muitos recorreram ao resultado de indeferimento de suas inscrições por meio de recurso e, ao se analisar o resultado do deferimento desses recursos, observamos com isso que a UFT conseguiu preencher por completo sua cota para surdos. Convém ressaltar que ao cotejar as notas dos resultados finais entre surdos e ouvintes, assim como foi identificado no estudo de Franco (2009), a maior nota pertenceu a um candidato surdo, bem como a média de notas dos aprovados surdos foi de 28,31 , enquanto os ouvintes apresentaram média de 25,9. Como a menor nota entre surdos e ouvintes foi a mesma, ou seja, 14,8, é interessante a percepção de que apesar da ausência da reserva de vagas, com o desempenho superior dos candidatos surdos nesse processo seletivo, eles seriam aprovados e classificados.

Entretanto, esse cenário ainda não pode ser generalizado, pois, por exemplo, a UFPI também conseguiu realizar o preenchimento integral das 11 vagas destinadas aos surdos, embora sem a medida da cota isso não teria ocorrido. Ao averiguarmos o resultado geral das notas, a maior entre os classificados da listagem da ampla concorrência foi 47,5 e a menor nota 32 pontos, ao passo que a maior nota entre os surdos foi 33 e a menor 19 pontos.

Concernente ao processo seletivo promovido pela Ufac, em 2013, foi reservado aos surdos $10 \%$ dentre as 50 vagas. Para as quais houve 13 surdos inscritos, sendo oito deles classificados e, por fim, cinco selecionados para preenchimento integral da cota. Isso significa que apesar de terem sido classificados oito surdos, como a reserva para esse grupo era restrita a $10 \%$, apenas cinco foram admitidos pela referida Ifes.

Alternativa distinta foi adotada pela Ufal em 2014. Das 30 vagas disponibilizadas por essa instituição, 11 eram destinadas a candidatos surdos, às quais foram submetidas 26 inscrições. Entretanto, no resultado final foram aprovados 15 participantes surdos, pois, na ausência de interessados na cota para escola pública, a Ufal as remanejou para os estudantes surdos, preenchendo e excedendo sua cota, previamente, dedicada aos surdos. Notamos assim que, quantitativamente, os episódios de Ifes que conseguiram preencher no total as vagas 
reservadas para surdos são menores se comparados àquelas que apresentaram dificuldades para fazê-lo. Como demonstrado, não é possível generalizar a dificuldade do preenchimento à baixa procura de surdos interessados, visto que em diversas situações houve mais inscrições de surdos do que o número de vagas reservadas e, mesmo assim, a reserva não foi preenchida.

No rastro dessa discussão, cabe citar os dados da UFRN que, apesar não ter manifestado a reserva de vagas para surdos em seus editais, disponibilizou o resultado de candidatos surdos e ouvintes em listas separadas, tal como preconizado no Decreto no 3.298/99 (BRASIL, 1999), isto nos permitiu verificar que, em 2013, das 40 vagas oferecidas foram aprovados 12 participantes surdos (dentre os 49 inscritos), um número consideravelmente superior ao de algumas instituições que se prestaram em seus editais a realizar reserva de vagas para esse público.

$\mathrm{Na}$ continuação, analisando o resultado dos alunos ouvintes e surdos desse ano na UFRN, entre os surdos a maior nota foi de 8,0 e a menor 3,0 enquanto entre os ouvintes a maior nota foi de 9,0 e a menor de 3,0 o que nos sugere um desempenho bastante similar entre surdos e ouvintes. No ano seguinte, dentre os 50 inscritos surdos, quatro foram aprovados, o desempenho dos surdos, contudo, foi inferior com 4,5 na maior nota e 3,5 na menor nota, enquanto a maior nota entre os ouvintes foi de 7,0 e a menor de 4,5. Já o panorama de 2015 compreende resultados mais positivos para os candidatos surdos, sendo dez candidatos aprovados e, dentre estes, a maior nota foi de 10,0 e a menor de 3,0, enquanto entre os ouvintes a maior nota foi de 9,5 e a menor de 3,5.

Nesta senda, a análise dos resultados da UFRN nos remete a duas reflexões. A primeira baseia-se na ideia de que não devemos nem podemos rotular o desempenho dos surdos como aquém ou além dos candidatos ouvintes. Em consonância com a crítica tecida por Kovács (2015), muitas vezes, a falta de informação sobre as pessoas com deficiência leva a crenças equivocadas de que elas precisam provar que são tão ou mais capazes em comparação aos demais. Para essa autora não podemos perder de vista que a “[...] valorização exagerada daquele que foi capaz de vencer barreiras também é uma forma de preconceito.” (KOVÁCS, 2015, p. 64).

A segunda reflexão é de que mesmo sem estabelecer a reserva de vagas, a UFRN conseguiu acolher mais surdos comparada a muitas daquelas que explicitamente se propuseram a fazê-lo. Se a baixa procura pelos cursos de Pedagogia bilíngue e Letras Libras não pode ser, isoladamente, responsabilizada pelo desafio no preenchimento das vagas destinadas aos candidatos surdos, assim como o baixo rendimento deles também não, visto que em alguns processos observamos melhor rendimento no resultado final dos candidatos surdos cotejado ao 
dos ouvintes, qual seria a justificativa? Certamente, como acenado anteriormente, não existe uma senão várias explicações plausíveis e nos parece aceitável que a elaboração das provas, a burocratização no processo de solicitação de condições especiais para acessibilidade (e interposição de recursos) e as altas notas de corte estabelecidas por alguns editais (alguns exigindo até $70 \%$ de acerto) consistem em agentes determinantes desse cenário.

Feita essa explanação acerca do preenchimento das vagas destinadas aos candidatos surdos, passamos, na sequência, para uma análise focalizada sobre o cruzamento entre as vagas destinadas aos surdos e as vagas reservadas pelas Ifes à PAA, categoria que fecha o terceiro eixo de análise concernente à disposição de vagas para surdos.

\subsubsection{Cruzamento entre a prioridade para surdos e a PAA}

A prioridade dos surdos ao acesso aos cursos de graduação para a formação de professores de Libras pode ser vista como uma política de focalização como ação reparatória, conceito apregoado por Kerstenetzky (2006), porquanto nos parece bastante oportuna em situações de desigualdades sociais tal como representado no contexto de acesso das pessoas surdas à educação superior. A desigualdade se torna evidente ao conferirmos o levantamento feito a partir de dados do Censo Demográfico de 2010 (INSTITUTO BRASILIERO DE GEOGRAFIA E ESTATÍSTICA, 2010), tal como pode ser observado na Tabela 5.5:

Tabela 5.5 - Levantamento de população surda e ouvinte com educação superior no Brasil feito a partir de dados do IBGE de $2010^{105}$

\begin{tabular}{ccccc}
\hline & \multicolumn{2}{c}{ Ouvintes } & \multicolumn{2}{c}{ Surdos } \\
\hline & Qtd. & Percentual & Qtd. & Percentual \\
\hline População Total & 173.733 .793 & $95 \%$ & 9.345 .345 & $5 \%$ \\
População acima de 19 anos & 114.137 .213 & $93 \%$ & 8.467 .976 & $7 \%$ \\
$\begin{array}{c}\text { Pessoas com mais de 19 anos e } \\
\text { com educação superior completa } \\
\text { ou incompleta }\end{array}$ & 20.074 .855 & $18 \%$ & 574.585 & $7 \%$ \\
\hline
\end{tabular}

Com base na Tabela 5.5, identificamos que 5,1\% da população brasileira declararam ter pelo menos alguma dificuldade permanente de audição, equivalente a 9,7 milhões dos 190,7

\footnotetext{
105 Os dados foram extraídos do sítio eletrônico Perfil Social, desenvolvido por Waldir Quadros, Alexandre Gori Maia e Vinicius Gaspar Garcia (2015). O sítio eletrônico apresenta um banco de consulta alimentado com dados do Censo Demográfico do IBGE de 2010, tendo como ferramenta de análise a metodologia de estratificação social. O sítio eletrônico permite uma consulta rápida aos dados do Censo Demográfico de 2010, a partir do uso de temas como localidade, escolaridade, capacidade de ouvir, enxergar etc.
} 
milhões de habitantes. Entendendo que o ingresso na educação superior ocorre com apenas uma parcela dessa população, realizamos um recorte de faixa etária de pessoas surdas e ouvintes acima de 19 anos (sendo nessa faixa etária uma proporção de $93 \%$ de pessoas ouvintes e $7 \%$ de pessoas surdas) e cruzamos os dados com o número de sujeitos que declararam ter a educação superior completa ou incompleta. Os resultados denotam que o acesso a esse nível de ensino é menor entre a população surda, sendo apenas $7 \%$ dos sujeitos surdos acima de 19 anos que afirmaram cursar ou já terem concluído o ensino superior, enquanto entre os ouvintes com idade acima de 19 anos o percentual atingiu $18 \%$.

Ainda que a prioridade das pessoas surdas não se estenda a todos os cursos universitários, esse quadro também pode ser usado como justificativa para o tratamento diferenciado aos candidatos surdos, quer dizer, como estabelecimento de políticas de focalização voltadas para equiparar as oportunidades entre grupos de pessoas ouvintes e surdas, tal como existem medidas para garantir o acesso de pessoas provenientes de escolas públicas, sobretudo os candidatos autodeclarados “pretos, pardos e indígenas", conforme Lei $\mathrm{n}^{\circ}$ 12.711, de 29 de agosto de 2012, na qual consta:

Art. $1^{\circ}$ As instituições federais de educação superior vinculadas ao Ministério da Educação reservarão, em cada concurso seletivo para ingresso nos cursos de graduação, por curso e turno, no mínimo $50 \%$ (cinquenta por cento) de suas vagas para estudantes que tenham cursado integralmente o ensino médio em escolas públicas.

Parágrafo único. No preenchimento das vagas de que trata o caput deste artigo, $50 \%$ (cinquenta por cento) deverão ser reservados aos estudantes oriundos de famílias com renda igual ou inferior a 1,5 salário-mínimo (um salário-mínimo e meio) per capita.

Art. $2^{\circ}$ (VETADO).

Art. $3^{\circ}$ Em cada instituição federal de ensino superior, as vagas de que trata o art. $1^{\circ}$ desta Lei serão preenchidas, por curso e turno, por autodeclarados pretos, pardos e indígenas, em proporção no mínimo igual à de pretos, pardos e indígenas na população da unidade da Federação onde está instalada a instituição, segundo o último censo do Instituto Brasileiro de Geografia e Estatística (IBGE).

Parágrafo único. No caso de não preenchimento das vagas segundo os critérios estabelecidos no caput deste artigo, aquelas remanescentes deverão ser completadas por estudantes que tenham cursado integralmente o ensino médio em escolas públicas. (BRASIL, 2012a, p. 1, grifo nosso).

A Lei ${ }^{0} 12.711 / 12$ privilegia os candidatos que cursaram o ensino médio integralmente em escolas públicas e possuam renda per capita igual ou inferior a um salário mínimo e meio, considerando ainda uma dupla compensação (DHANDA, 2008) àqueles que, além de terem estudado em escolas públicas e possuírem uma baixa condição de renda, autodeclarem-se negros, pardos ou indígenas, portanto em dupla situação de desvantagem. Nesses casos, tornou- 
se obrigatório às Ifes reservarem um percentual progressivo (alcançando o mínimo de 50\% até 2016) de suas vagas aos grupos "duplamente discriminados", emprestando o conceito de Dhanda (2008, p. 52), ponderando também a proporção da reserva de vagas ao número de “pretos, pardos e indígenas” (BRASIL, 2012a, p. 1) aferido pelo último censo demográfico com relação ao estado do país no qual a Ifes está situada.

Cabe destacar que a Lei $\mathrm{n}^{0}$ 12.711/12 (BRASIL, 2012a) é contundente na determinação de "reservas" de um "percentual" de vagas, distinguindo-se do Decreto n ${ }^{\circ}$ 5.626/05 (BRASIL, 2005) em que, ao estabelecer sobre a prioridade de acesso de pessoas surdas aos cursos de formação para professores de Libras, nada especifica quanto à distribuição das vagas tornando dúbia a interpretação dessa lei. Conforme dito, existe uma fragilidade no Decreto $n^{\circ}$ 5.626/05 (BRASIL, 2005) nesse aspecto, pois a falta de clareza sobre como atender a prioridade delegada aos surdos pode ser a grande responsável pelas múltiplas abordagens (como reserva de vagas ou como primazia) adotadas por diferentes Ifes na sua execução.

Ainda pensando sobre a PAA da Lei no 12.711/12 (BRASIL, 2012a) e sua relação com as determinações do Decreto $n^{\circ}$ 5.626/05 (BRASIL, 2005), vislumbrando ambos os documentos legais como normativas para a organização de processos seletivos referentes aos cursos aqui investigados, buscamos conferir os editais que acolheram a PAA cotejando-os aos editais que adotaram o critério de prioridade. Primeiramente, devemos destacar que 59 editais de nosso universo realizaram a reserva de vagas para PAA, sendo que alguns deles, tais como a UFG e a Ufsc já aderiram a essa medida desde 2008, data anterior à referida Lei $\mathrm{n}^{\circ}$ 12.711/12 (BRASIL, 2012a). Ainda assim, o aumento é mais acentuado a partir de 2012, como pode ser conferido nos indicadores do Gráfico 5.17.

Gráfico 5.17 - Representação dos editais com e sem reserva para PAA em processos seletivos para formação de professores de Libras localizados entre 2006 a 2015

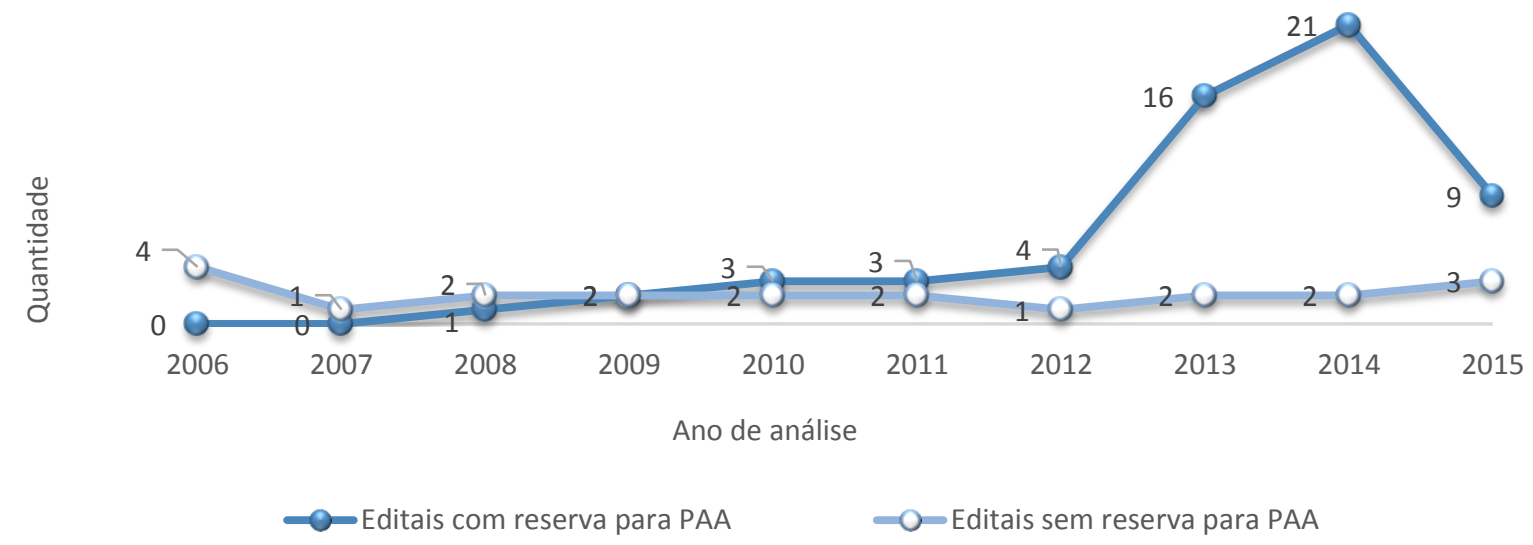


Como pode ser observado, há um índice ainda pequeno de Ifes que não respeitam a PAA, mas o que nos interessa destacar é que, apesar da supramencionada lei ter sido sancionada em 2012, ao passo que o Decreto $n^{\circ} 5.626 / 05$ (BRASIL, 2005) vigora há mais tempo, na soma total de editais ao longo do período de 2006 a 2015 (comparando os Gráficos 5.15 e 5.17), houve mais editais que respeitaram a PAA, ou seja, 59 editais, comparado aos 46 editais que obedeceram à prioridade dos surdos. Evidentemente, que, em virtude da PAA ter sido oficializada no ano de 2012, essa diferença se acentua a partir desse ano, mas, diante desse quantitativo geral, a que se deveria esse contraste? Talvez ao fato de, como apontado anteriormente, a maior precisão na distribuição das vagas ter sido elucidada na Lei $\mathrm{n}^{\circ}$ $12.711 / 12$ ?

Analisando os 59 editais a adotarem a reserva de vagas em conformidade com a PAA, verificamos que 28 atenderam somente a PAA, omitindo-se com relação à prioridade dos candidatos surdos, enquanto 31 documentos de editais cumpriram ambas as determinações legais, a saber, a Lei $n^{\circ}$ 12.711/12 (BRASIL, 2012a) e o Decreto ${ }^{\circ}$ 5.626/05 (BRASIL, 2005).

Desse montante de 31 editais decorreram dois movimentos. $\mathrm{O}$ primeiro em direção à admissão de um mesmo candidato acumular múltiplas condições de desvantagem social, permitindo durante a inscrição optar por mais de um grupo contemplado na reserva de vagas. O segundo, declinando com a exigência de que os candidatos optassem por um ou outro grupo de reserva de vagas. Foram 20 editais de nosso universo analisado que previram o cruzamento entre a prioridade para candidatos surdos e a reserva de vagas para PAA. Um exemplo pode ser conferido na Tabela 5.6 adaptada do edital da UFPR.

Tabela 5.6 - Distribuição das vagas do edital da UFPR (2014-2) para o processo seletivo de licenciatura em Letras Libras

\begin{tabular}{|c|c|c|c|c|c|c|c|c|}
\hline \multirow{4}{*}{ Categorias } & \multirow{4}{*}{$\begin{array}{c}\text { Total } \\
\text { de } \\
\text { vagas }\end{array}$} & \multirow{4}{*}{$\begin{array}{l}\text { Concorrência } \\
\text { geral }\end{array}$} & \multicolumn{6}{|c|}{$\begin{array}{c}\text { Distribuição de vagas conforme a Lei 12.711/12, Decreto } \mathrm{n}^{\circ} \\
7.824 / 12 \text { e Portaria } \mathrm{n}^{\circ} \text { 18/12 - MEC }\end{array}$} \\
\hline & & & \multicolumn{6}{|c|}{ Candidatos que estudaram em Escola Pública } \\
\hline & & & \multicolumn{3}{|c|}{$\begin{array}{c}\text { Renda }<= \\
\text { per capita }\end{array}$} & \multicolumn{3}{|c|}{ Independente da renda } \\
\hline & & & $\begin{array}{c}\text { Total } \\
\text { de } \\
\text { vagas }\end{array}$ & $\begin{array}{l}\text { Pretos, } \\
\text { pardos e } \\
\text { indígenas } \\
(28,51 \%)\end{array}$ & $\begin{array}{c}\text { Demais } \\
\text { vagas }\end{array}$ & $\begin{array}{l}\text { Total } \\
\text { de } \\
\text { vagas }\end{array}$ & $\begin{array}{c}\text { Pretos, } \\
\text { pardos e } \\
\text { indígenas } \\
(28,51 \%)\end{array}$ & $\begin{array}{c}\text { Demais } \\
\text { vagas }\end{array}$ \\
\hline $\begin{array}{c}\text { Surdos } \\
\text { (Decreto no } \\
5.626 / 2005)\end{array}$ & 22 & 13 & 5 & 2 & 3 & 4 & 2 & 2 \\
\hline Ouvintes & 8 & 4 & 2 & 1 & 1 & 2 & 1 & 1 \\
\hline
\end{tabular}

Fonte: Universidade Federal do Paraná (2014-2 [ingresso 2015-1 Presencial], p. 1)

A Tabela 5.6 demonstra que, para atender a Lei $n^{\circ}$ 12.711/12 (BRASIL, 2012a) e o Decreto $\mathrm{n}^{\circ}$ 5.626/05 (BRASIL, 2005), a UFPR dividiu as vagas do curso de licenciatura em 
Letras Libras em surdos e ouvintes, sendo $73 \%$ das vagas destinadas aos primeiros e $27 \%$ para ouvintes. A Ifes subdividiu as vagas entre concorrência geral e PAA, reservando $41 \%$ para surdos que haviam estudado em escolas públicas, prevendo, dentre esse percentual, vagas específicas para candidatos autodeclarados pretos, pardos e indígenas e com renda inferior ou igual a um salário mínimo e meio per capita.

Por outro lado, um modo distinto de cumprimento da PAA e da prioridade para surdos foi desvelado por 11 editais. Como um exemplo dessa organização, durante seu processo seletivo para ingresso no curso de Pedagogia bilíngue de 2014, o IFG designou 30\% das vagas para surdos, $50 \%$ para PAA e $20 \%$ para o sistema universal (a forma como o IFG denominou as vagas de ampla concorrência que não se destinam à PAA ou aos surdos), conforme Tabela 5.7 .

Tabela 5.7 - Distribuição de vagas do edital do IFG (2014-2) para o processo seletivo do curso de licenciatura em Letras Libras

Quadro de vagas do curso - Vestibular Pedagogia bilíngue 2015/1 Campus Aparecida de Goiânia

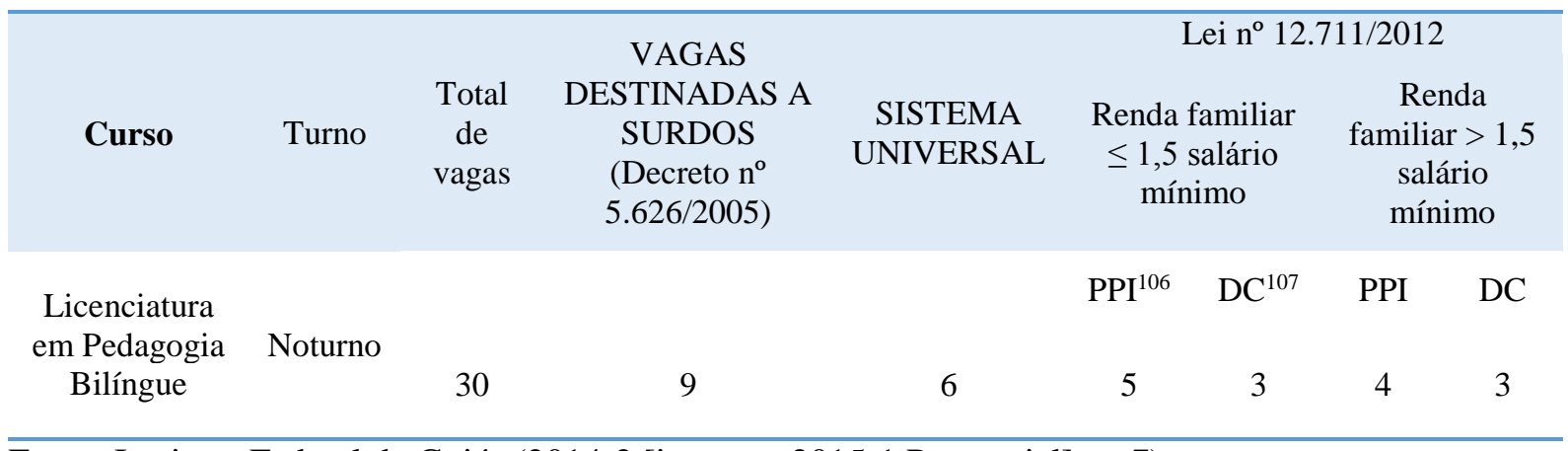

Fonte: Instituto Federal de Goiás (2014-2 [ingresso 2015-1 Presencial], p. 7)

A Tabela 5.7 indica a posição do IFG em desconsiderar a possibilidade de candidatos surdos se manifestarem, concomitantemente, como oriundos de escolas públicas com renda per capita inferior ou superior a um salário mínimo e meio e/ou "pretos, pardos ou indígenas" (BRASIL, 2012a). Isso se nota devido ao fato do IFG ter dividido suas vagas em quatro grupos e optado por não realizar o cruzamento entre as determinações do Decreto $n^{\circ}$ 5.626/05 (BRASIL 2005) e da Lei $n^{\circ}$ 12.711/12 (BRASIL, 2012a).

Similarmente, o texto deflagrado no edital da Ufac remete ao posicionamento do IFG, conforme Excerto 44:

\footnotetext{
${ }^{106}$ Registramos PPI obedecendo à redação utilizada pelo edital do IFG (2014-2 [ingresso 2015-1 Presencial], p. 7) para designar "pretos, pardos e indígenas".

${ }^{107}$ Registramos DC obedecendo à redação utilizada pelo edital do IFG (2014-2 [ingresso 2015-1 Presencial], p. 7) para designar "demais candidatos".
} 


\section{Excerto 44}

2.4. O candidato deverá efetuar sua inscrição no Processo Seletivo Específico, indicando:

a) o curso, dentre as opções oferecidas por este edital, para o qual deseja aprovação;

b) a modalidade de concorrência, dentre as opções abaixo:

i) vagas reservadas em decorrência do disposto na Lei $n^{0}$ 12.711/12 (que trata da reserva de vagas para estudantes egressos do ensino médio de escolas públicas, critério de renda e étnico-racial);

ii) vagas destinadas a candidatos com deficiência;

iii) vagas destinadas à ampla concorrência.

iv) para o curso de Letras: Libras, vagas destinadas a candidatos surdos, aqueles cuja deficiente auditiva corresponda a perda bilateral, parcial ou total, de quarenta e um decibéis (dB) ou mais, aferida por audiograma nas frequências de $500 \mathrm{~Hz}, 1.000 \mathrm{~Hz}, 2.000 \mathrm{~Hz}$ e $3.000 \mathrm{~Hz}$.

c) É vedada ao estudante a inscrição em mais de um curso ou em mais de uma modalidade de concorrência para o mesmo curso. (UFAC, 2013-2 [ingresso 2014-1 e 2014-2 Presencial] p. 1-2, grifo nosso).

Em editais recentes como, por exemplo, o da Ufac (Excerto 44), do segundo semestre de 2013, e do IFG (Tabela 5.7), do segundo semestre de 2014, entendemos que a proposta de dupla compensação, preconizada por Dhanda (2008), não tenha sido contemplada. Significa dizer que surdos de camadas populares, oriundos de escolas públicas, autodeclarados pretos, pardos ou indígenas deveriam, nesses editais, optar por concorrer como surdos ou como PAA, ainda que atendessem aos dois critérios. Contudo, a nosso ver, cabe parafrasear a autora e questionar se essa é a melhor alternativa para “[...] tratar da vulnerabilidade daqueles que estão em desvantagem em mais de um parâmetro?” (DHANDA, 2008, p. 51).

A dupla desvantagem merece também atenção por parte de Castel (2011), ao advogar que em condições de minorias étnicas discriminadas simultaneamente pela raça e pela classe social são justificadas ações de discriminação positiva. Para justificar as políticas de discriminação positiva, o autor defende que quando o sujeito sofre de múltiplas desvantagens deve ser auxiliado diferenciadamente, pois só assim será capaz de superar o contexto de exclusão. Ao discutir sobre questões étnicas e raciais associadas a uma baixa situação econômica afirma:

Diante disso, não vemos outra opção senão implementar políticas de discriminação positivas. A distância entre a situação destes jovens e o regime comum (em relação à escola, ao trabalho, mas igualmente com frequência em termos de habitação e de condições da vida cotidiana) é tão grande que medidas especiais tornam-se necessárias, sobretudo a transferência de suplementos de recursos para os desprovidos. Isso quer dizer o seguinte: precisamos de políticas de discriminação positivas. (CASTEL, 2011, p. 104).

Para Boneti (2006, p. 189), que se respalda nos estudos desse autor, os excluídos não constituem um grupo homogêneo, eles “[...] acumulam a maior parte das desvantagens sociais: 
pobreza, falta de trabalho, sociabilidade restrita, condições precárias de moradia, grande exposição a todos os riscos de existência, etc.” Cumpre destacar que, embora Castel (2011) e Boneti (2006) não retratem a convergência desses fatores com a deficiência ou com a surdez, autores como Skliar (2003) e Perez (2008) emprestam conceitos desse intelectual francês (CASTEL, 2011) para compreender a condição de exclusão no contexto da educação de surdos (SKLIAR, 2003) e das pessoas com deficiência (PEREZ, 2008), uma aproximação que também intentamos aqui.

A contribuição de Castel (2011) se assenta no reconhecimento da necessidade de políticas de discriminação positiva aos grupos que se encontram em mais de uma condição de desvantagem social, tendo em vista que essa seria a única solução para equiparar as oportunidades e auxiliá-los a superar a situação na qual se encontram. Nessa lógica, consideramos que surdos e negros, surdos e índios (VILHALVA, 2009; 2012), surdos com baixas condições econômicas, entre outras combinações deveriam ser duplamente contemplados.

Ademais, faz-se mister problematizar a surdez a partir do conceito de identidade postulado por Hall (1998), para quem o indivíduo pós-moderno não é constituído por uma senão várias identidades. $\mathrm{O}$ autor acredita que as identidades modernas estão em colapso devido às mudanças estruturais pelas quais as sociedades modernas têm passado desde o final do século $\mathrm{XX}$. Isso está fragmentando as paisagens culturais de classe, gênero, sexualidade, etnia, raça e nacionalidade, que antes forneciam sólidas localizações como indivíduos sociais.

Essa discussão, leva-nos a crer que as identidades surdas também participam da chamada "crise de identidades" citada por autores como Hall (1998) e Woodward (2000). Segundo Hall (1998), o sujeito unificado e as identidades fixas estão em declínio para dar lugar às novas identidades que têm fragmentado o indivíduo moderno. Assim, como exposto no Capítulo 3, atualmente acompanhamos a ascensão do sujeito pós-moderno desvinculado de uma identidade unificada e estável, na verdade é um sujeito formado de várias identidades, frequentemente, contraditórias e/ou não-resolvidas. Os processos de identificações são provisórios e problemáticos, sua identidade é formada e transformada continuamente em relação ao modo como nos posicionamos nas relações sociais.

Para ilustrar o que estamos tentando discutir, é possível citar Silva e Kumada (2009) ${ }^{108}$, cujo trabalho consistiu em desvelar o dilema de uma menina surda, negra e pobre que em seu

\footnotetext{
${ }^{108}$ Este trabalho foi congratulado com o $1^{\circ}$ lugar no II Congresso Nacional de Diversidade e Inclusão, realizado no Núcleo do Parque Tecnológico de São José dos Campos, em 2009.
} 
contexto escolar junto aos alunos ouvintes era discriminada, ora por ser surda, ora por ser pobre. No contraturno, durante sua participação em atendimento de apoio pedagógico bilíngue, entre colegas surdos, era discriminada por ser negra. As múltiplas identidades dessa menina evidenciam o conflito do sujeito pós-moderno que não se encontra unificado por uma identidade, mas fragmentado em várias. Suas identidades podem ser suspensas ou fortalecidas de modo provisório em face do contexto em que se encontram situadas, pois, em consonância com Hall (1998), o processo de identificação no qual a identidade é projetada se transformou em provisório, variável e problemático.

A menina descrita por Silva e Kumada (2009) materializa o referido sujeito pósmoderno ao qual almejamos lançar luz, pois quando vislumbramos os dilemas de suas diferentes identidades depreendemos os riscos de um indivíduo como ela não ser visto em sua integralidade, ou seja, como uma criança surda, negra e pobre. É incontestável que a coabitação dessas identidades a situam em uma condição diferenciada dos surdos brancos ou dos negros ouvintes, pois não está em um ou noutro grupo, senão nos dois, ao mesmo tempo nas bordas, nas fronteiras, no entre lugares, nos interstícios, ou seja, no terceiro espaço, como postula Bhabha (2007).

Em harmonia com essa visão crítica e ampliada, convém também reforçar nosso posicionamento com relação à noção de identidade essencializada, pois em concordância com Maher (1998), o conceito de identidade não está vinculado a uma essência biológica ou cultural. Para a autora, tal conceito representa um "constructo sócio-histórico" estabelecido nas práticas discursivas, no uso da linguagem, nas relações entre as pessoas (MAHER, 1998, p. 117), o que nos remete à percepção de que se a identidade é projetada e construída no uso da linguagem e não por uma característica orgânica, não se pode fixá-la e/ou inscrevê-la no corpo do sujeito.

Essa reflexão nos permite problematizar, por exemplo, a opção do Ines durante os processos seletivos realizados até 2011, quando restringia a reserva de vagas aos candidatos que comprovassem perda auditiva severa ou profunda, acenando que sua concepção de identidade surda estaria sujeitada ao grau do seu comprometimento auditivo. Importa sublinhar que a própria definição do artigo $2^{\circ}$ do Decreto $n^{\circ}$ 5.626/05 (BRASIL, 2005) ultrapassa a concepção audiológica, ao conceber o surdo sob aspectos linguísticos e culturais.

Nesta premissa, tal como Lopes (2011, p. 14), projetamos a necessidade de trazer à tona debates envolvendo a essencialização do sujeito surdo, como se estivéssemos em busca de alguma “[...] 'pureza' na forma surda de ser, pensar e relacionar-se", entendemos assim como a autora que: 
Não há uma forma correta, uma identidade surda mais definida que outra, não há um conceito melhor, não há uma essência surda, nem mesmo um estágio que marque um desenvolvimento cultural desejado. Mas há formas diferentes de viver a condição de ser surdo e de pertencer a um grupo específico. (LOPES, 2011, p. 14).

Assumir a surdez como diferença é, como vimos defendendo, admitir esse contexto como sociolinguisticamente complexo (emprestando a expressão cunhada por Cavalcanti, 1999), ao entender que o bilinguismo é, na verdade, um multilinguismo e que a identidade surda é, por sua vez, plural e não essencializada. A partir desse raciocínio, acreditamos que essa deveria ser a (ou a expectativa da) perspectiva vislumbrada nos editais de vestibulares para formação de professores de Libras. Entendemos que, por exemplo, a dificuldade de atender, simultaneamente, as exigências da Lei $\mathrm{n}^{\circ}$ 12.711/12 (BRASIL, 2012a) e do Decreto ${ }^{\circ}$ 5.626/05 (BRASIL, 2005), pode ser, em grande parte, decorrente dos desafios em se obter orientações aclaradas acerca da maneira mais adequada de realizar tal cruzamento entre a PAA e a prioridade para surdos no ingresso aos cursos de formação de professores de Libras. Contudo, isso poderia ser facilmente resolvido, por meio de um parecer, portaria ou outra manifestação do MEC ou de órgãos superiores responsáveis.

Apesar disso, o mais importante é enfatizar que tanto a PAA como a prioridade para surdos não devem se tornar medidas permanentes, pois, como coloca Castel (2011), estas devem ser transitórias e de função propedêutica a fim de culminar em uma reforma mais ampla, sobretudo, na educação básica. Por isso, defendemos que o primeiro passo para promover mudanças significativas na educação de surdos é trocar as lentes do deficientismo pelas do diferencialismo (BEHARES, 2015), pois conforme tentamos expor, para um novo paradigma torna-se crucial que haja novos olhares para o surdo, para a surdez, para a língua de sinais, para o bilinguismo de contextos minoritários/minoritarizados e para as identidades surdas.

Com essa exposição, encerramos o capítulo da análise e discussão dos resultados para, na sequência, contemplarmos as últimas palavras desta pesquisa a serem compartilhadas nas considerações finais. 


\section{CONSIDERAÇÕES FINAIS}

Para brindar o desfecho do presente estudo, apresentaremos uma síntese dos resultados alcançados com os objetivos inicialmente propostos, nossas impressões e contribuições acerca do contexto investigado, bem como algumas sugestões para futuras pesquisas. Lembramos que, em nossa tese, estabelecemos como objetivo geral investigar e analisar o acesso do surdo a cursos superiores de formação de professores de Libras em instituições federais. Para cumprir esse desígnio, propusemo-nos a atingir quatro objetivos específicos, a saber: realizar o levantamento de cursos de Pedagogia bilíngue e Letras Libras ofertados no país na última década; traçar uma caracterização dos processos seletivos (vestibulares) envolvendo os cursos de Letras Libras e Pedagogia bilíngue realizados pelas Ifes; analisar as condições de acessibilidade disponibilizadas pelas Ifes aos candidatos surdos durante os vestibulares envolvendo cursos de Letras Libras e Pedagogia bilíngue; e identificar e discutir a disposição de vagas ofertadas pelas Ifes nos cursos de Letras Libras e Pedagogia bilíngue.

A respeito dos resultados obtidos por meio do levantamento de cursos de Pedagogia bilíngue e Letras Libras ofertados no país na última década, expusemos o número de cursos e IES cadastradas na base de dados do e-MEC, no qual destacamos que $73 \%$ das instituições promotoras de cursos de formação de docentes de Libras são Ifes, não tendo, inclusive, sido localizado nenhum curso de Pedagogia bilíngue entre as IES estaduais e privadas. Constatamos ainda que, até a data da nossa última consulta ao e-MEC, o único estado do país sem registro de nenhum curso superior para formação de docentes da Libras foi o de Rondônia, visto que os demais estados apresentaram alguma IES cadastrada neste segmento ou foram contemplados com a oferta de cursos na modalidade EaD. Ainda assim, esse levantamento nos permitiu verificar que, na maior parte do território brasileiro, existe somente um ou dois desses cursos por estado, o que pode indicar, conforme Lacerda, Albres e Drago (2013), a insuficiência dessa oferta para atender a demanda nacional da educação bilíngue para surdos.

Para os outros três objetivos específicos, é válido recordar que os resultados provieram de uma pesquisa documental de abordagem qualitativa, na qual 80 editais de processos seletivos, bem como seus respectivos documentos anexos e complementares foram analisados e discutidos durante o Capítulo 5 à luz de nosso referencial teórico, pautado, principalmente nos Estudos Culturais e Estudos Surdos em educação, bem como nas contribuições da Linguística Aplicada.

Nessa direção, com o fito de traçar uma caracterização dos processos seletivos (vestibulares) abrangendo os cursos de Letras Libras e Pedagogia bilíngue realizados pelas Ifes 
abordamos diferentes aspectos, tais como, a publicação de editais para processos seletivos, a oferta dos cursos, a adesão das Ifes, o número de vagas disponibilizadas, a influência da modalidade de educação, as formas de ingresso e os pré-requisitos exigidos aos candidatos, em particular, o pré-conhecimento da Libras feita por algumas Ifes.

Mediante os resultados alcançados, pudemos depreender que houve um lento avanço entre 2006 e 2012 em relação ao número de Ifes dedicadas à oferta de cursos de Letras Libras e Pedagogia bilíngue, porém, de 2013 a 2015 notamos um expressivo aumento dessa quantidade, de cinco Ifes no primeiro período para 18 no segundo período. Para explicar esse fenômeno, aventamos a contribuição do Programa Viver sem Limite, cuja meta era a expansão dos cursos de formação para docência da Libras (BRASIL, 2013b).

Entretanto, concluímos que a meta não conseguiu ser integralmente cumprida e nossos indicadores demonstraram que o segmento mais prejudicado ao longo desses anos recaiu no curso de Pedagogia bilíngue, responsável pela formação de docentes de Libras que atuarão na educação infantil e anos iniciais do ensino fundamental. Sobre esses cursos, identificamos somente duas Ifes (o Ines e o IFG) que, juntas, disponibilizaram 639 vagas entre 2006 e maio de 2015, ao passo que as 23 Ifes dedicadas ao curso de Letras Libras ofertaram 3.676 vagas no mesmo período de análise. Dados como esses podem servir como alerta para a urgência de medidas governamentais, sobretudo do MEC, para suprir a lacuna de pedagogos formados para a docência da Libras, uma vez que, conforme disposto no artigo 11 do Decreto $\mathrm{n}^{\circ}$ 5.626/05 (BRASIL, 2005), coube ao referido órgão promover programas para criação de cursos de graduação que formem professores surdos e ouvintes para atuarem na educação bilíngue em Libras e Língua Portuguesa.

Nossos resultados também revelaram na EaD uma grande aliada na oferta de vagas para formação de professores de Libras em cursos superiores, porquanto os três cursos de Letras Libras EaD (da Ufsc, da UFPB e da UFGD) foram responsáveis por 47\% do total de vagas disponibilizadas no recorte temporal aqui investigado. Além disso, é válido pontuar que, mediante o levantamento realizado em nossa pesquisa, confirmamos o favorecimento desta modalidade para se obter maior abrangência geográfica, pois, por intermédio dos três cursos $\mathrm{EaD}, 36$ municípios de diversos estados do país foram atendidos, ao passo que os 23 cursos presenciais serviram apenas aos respectivos 23 municípios onde as Ifes estavam alocadas.

Ademais, por meio da caracterização dos processos seletivos averiguamos que a organização de provas pelas Ifes em seus vestibulares embora tenha sido a principal, não se limitou a ser a única forma de selecionar os candidatos para ingresso nos cursos de Letras Libras e Pedagogia bilíngue. Durante a última década, muitas Ifes investigadas optaram por processos 
seletivos baseados no aproveitamento parcial ou integral da nota do Enem (via Sisu), pela formação de profissionais da educação em serviço (via PAR ou Parfor) ou pelo CR de alunos já graduados. Acerca dessa informação, assinalamos ser necessária cautela com o uso dessas alternativas, uma vez que a avaliação do Enem tem sido alvo de bastante polêmica, seja pela formulação de suas questões com respostas dúbias (SILVEIRA; BARBOSA; SILVA, 2015) seja pela falta de tradução integral da prova para a Libras (PEREIRA, 2016), o que poderia comprometer o acesso de candidatos surdos a essas Ifes. Analogamente, versamos a respeito dos riscos de se restringir o ingresso aos cursos de formação de professores aos candidatos que já apresentem uma graduação, tendo em vista os desafios que muitos estudantes surdos enfrentam para acessar e concluir a educação superior (DAROQUE, 2011; DAROQUE; QUEIROZ, 2013).

Nosso estudo também permitiu problematizar a exigência de conhecimento prévio da Libras, feita em $42 \%$ dos processos seletivos investigados. Nesse viés, com exceção do Ines, as Ifes que avaliaram o desempenho prático da Libras concentraram somente em uma habilidade linguística, ou seja, na avaliação da compreensão desse sistema linguístico e não de seu uso de forma comunicativa e interativa. Por outro lado, houve processos seletivos que examinaram a compreensão teórica "sobre" a Libras e questões relacionadas, como, por exemplo, o ensino da Libras como L1 e L2, a história da educação de surdos, os aspectos legais, linguísticos e culturais, bem como a tradução e interpretação da Libras. Em ambas as situações, desvelamos um grande desconhecimento sobre o contexto sociolinguisticamente complexo da surdez (CAVALCANTI, 1999) e sobre estratégias de avaliação das competências linguísticas. Em algumas provas, por exemplo, vislumbramos textos significativamente empobrecidos (e poderse-ia dizer infantilizados), com questões do gênero "O que cai da árvore são folhas, minhocas ou borboletas?". E, já em outros contextos, localizamos editais a exigir que a prova de todos os conteúdos escolares (tais como Física, Química, Biologia, História, Geografia etc.) fossem avaliadas, exclusivamente, em Libras. Em posse desses dados, discutimos que medidas como essa última ignoram o fato de a Libras ter um repertório linguístico de termos específicos por disciplinas com pouco registro, catalogação e divulgação, isto compromete a exigência de um domínio desses conteúdos centrados apenas no vocabulário da Libras (MARINHO, 2007; STUMPF; OLIVEIRA; MIRANDA; 2014; KUMADA et al., 2015). Ademais, buscamos, em diálogo com nosso referencial teórico, defender que o sujeito bilíngue é formado por dois repertórios linguísticos, cujas competências o permitem transitar de uma língua para outra e, portanto, a avaliação que o situe tão somente em uma língua é, como declara Maher (2007), uma avaliação parcial. 
No tocante ao nosso objetivo de analisar as condições de acessibilidade disponibilizadas pelas Ifes aos candidatos surdos durante os vestibulares envolvendo cursos de Letras Libras e Pedagogia bilíngue, observamos que o ingresso dos estudantes surdos a esses cursos pode ter sido prejudicado pela omissão das Ifes ou pela burocratização enfrentada no processo de obtenção do direito à acessibilidade.

Quanto à omissão das Ifes, constatamos que as condições de acessibilidade deixaram de ser previstas por muitos editais de processos seletivos, a começar pela tradução do conteúdo dos editais para a Libras, verificamos que $61 \%$ destes não foram traduzidos e outros $6 \%$ realizaram uma tradução parcial ou resumida. Fato que julgamos preocupante por infringir o direito de acesso à informação pelos candidatos surdos (BRASIL, 2005). Por sua vez, apenas $47 \%$ de editais se manifestaram sobre a prova ser acessível em Libras, fosse via projeção e/ou com acompanhamento de um tradutor e intérprete de Libras. Em um índice ainda menor, só uma parcela de $27 \%$ dos editais analisados registrou o direito do candidato surdo solicitar tempo adicional para a realização da prova (BRASIL, 1999), enquanto 23\% permitiram ao surdo requerer autorização para o uso do Aasi durante o exame vestibular. A correção diferenciada da prova discursiva de Língua Portuguesa e/ou redação, como prevê o Decreto $n^{0} 5.626 / 05$ (BRASIL, 2005), tratou-se de um direito assegurado em apenas 30\% dos processos seletivos. E, aos candidatos insatisfeitos com a correção da redação, evidenciamos que $29 \%$ dos editais permitiram a reivindicação de vistas a essa prova ou a interposição de recursos a sua correção. Em outras palavras, aferimos que a maior parte dos processos seletivos não reconheceu em seus editais a correção diferenciada aos candidatos surdos que consiste em um direito legal e, por extensão, não lhes foi permitido reclamarem da correção aplicada que, possivelmente, tenha desconsiderado uma reflexão acerca da condição bilíngue dos surdos.

Não obstante, nossos resultados indicaram que os desafios enfrentados pelos candidatos surdos longe de ficarem circunscritos à omissão dos editais, estenderam-se ao processo de burocratização para obterem o deferimento das condições de acessibilidade solicitadas. Isso porque os processos seletivos que previram a requisição do direito de acessibilidade e o de prioridade no ingresso por parte dos surdos, incluíram inúmeras exigências de comprovação da surdez, principalmente, por laudos e exames clínicos, onde figurassem, por exemplo, o CID, a causa, o tipo e grau de surdez, o ganho auditivo obtido com e sem o uso do Aasi, além da justificativa do médico especialista para o candidato ser beneficiado com o direito de tempo adicional, correção diferenciada da prova de português uso do Aasi ou outra condição diferenciada. Após toda a comprovação entregue, as Ifes, frequentemente, ainda convocavam os requerentes surdos para passarem por nova perícia médica feita por equipe própria da 
instituição. Constatamos que, muitas vezes, indeferia-se as solicitações alegando, por exemplo, exame de audiometria antigo ou não original, documentação incompleta, falta de justificativa do médico para a condição diferenciada na prova, entre outras.

No rastro dessa lógica, evidenciamos um número significativo de surdos que deixou de ser assistido nos seus direitos por ter apresentado, por exemplo, uma audiometria com data anterior a seis meses ou não ter repetido o exame com e sem o uso do Aasi. Para ilustrar essa passagem, é possível resgatar os dados da UFG, Ifes que indeferiu 87\% das inscrições de candidatos requerentes a tempo adicional para realização das provas e $83 \%$ dos que pediram correção diferenciada da prova escrita. Em face disso, compreendemos que os critérios adotados pelas Ifes para dirimir sobre as questões de acessibilidade e prioridade para surdos não favorecem o ingresso dos surdos aos cursos de Letras Libras e Pedagogia bilíngue, não apenas por deixarem uma grande parcela desse contingente desassistida, mas porque, em $98 \%$ das situações, seguiram um enfoque audiológico de comprovação da surdez mediante laudo médico e/ou exame de audiometria. Essa realidade denunciou a flagrante dificuldade dessas Ifes de encontrarem alternativas sob um viés cultural para se desvincular a identidade surda do referente audista e do assujeitamento da Educação Especial e dos Estudos Surdos à área clínica.

Nessa direção, o desenvolvimento desta pesquisa permitiu desvelar a força do discurso médico ainda muito presente durante os processos seletivos que regulam o acesso dos surdos à graduação para formação de professores de Libras. Isso ocorreu não apenas no uso de parâmetros clínicos para definir as condições de acessibilidade e o direito de prioridade, mas, inclusive no próprio vocabulário empregado na redação de provas e editais que insistiam em se referir ao surdo pela nomenclatura "deficiente auditivo" ou "portador de deficiência auditiva", ou ainda ao conceituar a Libras como uma "linguagem de sinais". Com essa análise, observamos que a atual configuração do acesso dos surdos aos cursos de Letras Libras e Pedagogia bilíngue corresponde a um tempo e a um espaço de ambivalências e contradições (SKLIAR, 2003; BHABHA, 2007), na qual se busca formar profissionais para uma educação bilíngue pautada na cultura da surdez como diferença, ao mesmo tempo em que se reproduz as mesmas práticas audistas rechaçadas pelos defensores de uma concepção socioantropológica.

Em relação ao nosso objetivo específico de identificar e discutir a disposição de vagas ofertadas pelas Ifes nos cursos de Letras Libras e Pedagogia bilíngue, nossos resultados revelaram três dificuldades principais por parte das Ifes, a saber: definir como atribuir o critério de prioridade dos candidatos surdos assegurado pelo Decreto $\mathrm{n}^{\circ}$ 5.626/05 (BRASIL, 2005); preencher as vagas reservadas para os candidatos surdos, garantindo o seu direito de ingresso nos cursos superiores de formação de docentes da Libras; e articular, concomitantemente, a 
reserva de vagas para PAA (BRASIL, 2012a) e a prioridade para candidatos surdos (BRASIL, 2005).

Percebemos que, embora esteja legalmente prevista a prioridade dos surdos no acesso aos cursos de formação de docentes da Libras, $43 \%$ dos editais deixaram de garantir esse direito e os que o fizeram tiveram diferentes interpretações sobre como atender a esse critério (BRASIL, 2005). Por um lado, a prioridade foi entendida como o que denominamos de primazia, ou seja, quando candidatos ouvintes só podem competir no caso de haver vagas remanescentes após o ingresso dos surdos. Enquanto em uma segunda interpretação das Ifes, a prioridade se pautou na reserva de um quantitativo ou percentual de vagas destinadas aos surdos, entretanto, não houve um consenso entre as Ifes sobre o valor, chegando a variar entre $10 \%$ a $80 \%$, conforme a instituição ou o ano do processo seletivo, pois houve Ifes cuja cota foi alterada de um ano para o outro.

Ao participante surdo, destaca-se que a previsão de uma reserva de vagas ou primazia nos editais não assegurou seu ingresso, tendo em vista que ao confrontarmos os resultados de processos seletivos que divulgaram a lista de candidatos aprovados, averiguamos que, frequentemente, as vagas reservadas para surdos não foram preenchidas por estes, mesmo que na maioria das situações houvesse um número de inscritos surdos superior ao número de vagas destinadas a esse público.

Além disso, nossa análise sobre a disposição das vagas retratou, por parte das Ifes, ainda uma forte negligência do reconhecimento da articulação das múltiplas condições de desvantagem enfrentadas por candidatos surdos e negros, surdos e índios, surdos e pobres, surdos e oriundos da escola pública. Isso porque, ao considerarmos a reserva realizada para os estudantes de escolas públicas autodeclarados pretos, pardos e indígenas e/ou com baixas condições socioeconômicas (BRASIL, 2012a) e o seu cruzamento com a prioridade atribuída aos participantes surdos (BRASIL, 2005), concebemos que houve uma grande parte dos processos seletivos que optou por atender somente a PAA e não a prioridade, enquanto outros impuseram ao candidato escolher entre concorrer às vagas para surdos ou às vagas para PAA. Nessa dinâmica, fez-se uma leitura unificada do conceito de identidade que, a nosso ver, destoa da visão de sujeito pós-moderno de identidades fragmentadas e multifacetadas presente na atual sociedade contemporânea (HALL, 1998, 2000; SILVA, 2000; WOODWARD, 2000). Em sintonia ao nosso aporte teórico, defendemos o reconhecimento do sujeito pós-moderno determinado sob diferentes identidades (HALL, 1998, 2000), ajuizando que para a construção de uma escola mais justa (DUBET, 2004) se faz necessário a adoção de medidas de discriminação positiva (CASTEL, 2011) ou de dupla compensação (DHANDA, 2008) que 
atuem como políticas de focalização como ação reparatória (KERSTENETZKY, 2006) aos sujeitos que exorbitam em mais de uma situação de exclusão.

Isso posto, de modo geral, conferimos que o Brasil tem dado passos lentos no que diz respeito à formação universitária de professores surdos e ouvintes para a docência da Libras. Como pode ser acompanhado a partir dos nossos resultados, houve avanços nessa década ulterior à publicação do Decreto $\mathrm{n}^{0} 5.626 / 05$ (BRASIL, 2005). É possível vislumbrar que IES de diferentes regiões do país se lançaram na proposta de formação de profissionais para atuação na docência da Libras e que, nesse processo, muitos indivíduos surdos ingressaram e concluíram essa formação. Julgamos que as Ifes com maior experiência aprenderam mais que as outras com os anos, realizando adequações em seus processos seletivos como, por exemplo, o Ines que, a partir de 2012, deixou de reservar as vagas para surdos exclusivamente aos que apresentassem perdas auditivas severa e profunda e começou a aceitar também os surdos moderados, ou ainda quando passou a registrar as avaliações em Libras através de mídia digital. A Ufsc, também pioneira, que, a princípio, ofertava o curso de Letras Libras EaD, a partir de 2009, dedicou-se ao curso presencial, sendo a única a aproveitar sua experiência em ambas as modalidades. Além disso, a partir do processo seletivo de 2012, essa Ifes passou a oferecer aos candidatos (surdos e ouvintes) de seus diversos cursos (não apenas o de Letras) a opção de escolher a Libras como sistema linguístico da prova de língua estrangeira, antes restrita às línguas de prestígio como inglês, espanhol e italiano. Infelizmente, a maioria das Ifes investigadas iniciou sua trajetória há menos de três anos e, pelo que pudemos apreender, fizeram pouco proveito do conhecimento acumulado pelas suas antecessoras.

Assim, apesar da comprovada evolução, não desconsideramos que há muito para se fazer nesse contexto, a começar pelo quantitativo de cursos e de oferta de vagas que precisa ser urgentemente ampliado para atender adequadamente a demanda da educação bilíngue de surdos no cenário brasileiro, sobretudo concernente ao segmento da educação infantil e anos iniciais do ensino fundamental que notamos serem os mais defasados. A prioridade de surdos na formação de professores de Libras deve ser melhor estruturada para que haja efetivamente a fruição desse direito, tal como referendado no Decreto n ${ }^{0}$ 5.626/05 (BRASIL, 2005). Para isso, defendemos que seja essencial diminuir as barreiras que têm impedido o sujeito surdo de ser assistido em suas condições de acessibilidade e atribuição da referida prioridade (BRASIL, 1999, 2005). Como sugerido em nosso texto, apreciamos que seria oportuno, ao invés de condicionar esses direitos a uma série de comprovações clínicas e patológicas, buscar alternativas que admitam maior coerência com os Estudos Surdos de viés antropológico. 
Em outras palavras, talvez fosse o caso de requerer relatórios pedagógicos de sua trajetória escolar ou de realizar uma comparação à PAA de reserva de vagas aos estudantes negros, aos quais não é impelida qualquer comprovação biológica ou de fenótipo, uma vez que suas identidades são afirmadas por meio de autodeclaração. Ou ainda poderíamos buscar inspiração no contexto indígena, em que aos seus respectivos candidatos tem sido solicitado um documento emitido por autoridade indígena reconhecida ou pela Funai. Estratégias que se desvencilham da essencialização da identidade negra ou indígena e que poderiam ser importadas para se pensar também as identidades surdas fora dos marcadores audistas (LOPES, 2011). Sob essa ótica, as Ifes aceitariam uma autodeclaração surda ou um documento emitido por uma autoridade surda, pela Feneis ou outra associação de surdos reconhecida.

Do mesmo modo, entendemos que os editais e documentos investigados nesta pesquisa são produzidos por pessoas que representam instituições de ensino e, portanto, cabe ao MEC e às próprias comunidades surdas fiscalizarem e cobrarem dessas instituições o cumprimento do Decreto $n^{0}$ 5.626/05 e do Decreto $n^{0} 3.298 / 99$ (BRASIL, 2005, 1999), seja no que tange a acessibilidade e prioridade no acesso dos sujeitos surdos, como também sobre um maior respeito e valorização da Libras como um sistema linguístico, do surdo como bilíngue e da surdez como diferença, rompendo com as engessadas representações patológicas reproduzidas nesse contexto.

Com base no exposto, acreditamos ter atendido ao nosso objetivo geral de investigar e analisar o acesso do surdo a cursos superiores de formação de professores de Libras em instituições federais. $\mathrm{O}$ desenvolvimento desta pesquisa não só permitiu somar contribuições a respeito dos desdobramentos da oferta desses cursos de graduação, ainda recentes, no país, bem como proporcionou a análise das condições de acesso disponibilizadas pelas Ifes aos candidatos surdos e a verificação da obediência às determinações legais envolvendo o direito de prioridade atribuído aos surdos para formação nesses cursos.

Em síntese, evidenciamos que o acesso dos surdos aos cursos de Letras Libras e Pedagogia bilíngue pode ter sido prejudicado nessa última década por vários fatores, dentre os quais citamos: a própria falta da oferta desses cursos no país; a forma de ingresso determinada por algumas Ifes que se pautavam pela nota do Enem; pela exigência dos candidatos serem professores ou já graduados; as estratégias de avaliação linguística inadequadas; a dificuldade de serem atendidos em suas condições especiais para a realização dos exames vestibulares seja pela omissão ou pela burocratização das Ifes; e a resistência e/ou o desconhecimento das Ifes de lidar com as identidades surdas articuladas a outras condições de desvantagem social, prevendo a dupla compensação postulada por Dhanda (2008). Nossa colaboração consistiu em 
identificar e compartilhar esses desafios como uma forma de visibilizá-los, para que possam ser abordados e minimizados, propiciando melhores condições de acesso dos surdos aos cursos superiores de formação para docência da Libras.

Evidentemente, assumimos que trouxemos apenas um fragmento de contribuição para a educação de surdos, especificamente voltado para o ingresso dos surdos nos cursos de graduação de Letras Libras e Pedagogia bilíngue das Ifes aqui investigadas. É válido pontuar que não há em nós ingenuidade de alimentarmos a crença de que o acesso a esse nível de ensino, inclusive por intermédio de reserva de vagas, solucione todas as questões e encerre o assunto. É possível assimilar o acesso como um primeiro passo ou como uma porta de entrada e, dessa maneira, outros passos e outras portas e janelas o sucederão. Certamente, se o acesso dos surdos à educação superior estiver comprometido, a permanência e a conclusão da formação podem ser prejudicadas, contudo, o pleno acesso também não significa a garantia da permanência e conclusão. Parafraseando Prieto (2000, p. 30), as necessidades desse grupo não são “[...] meramente de ordem quantitativa [...]" e nem "[...] podem ser supridas, tão somente, pela expansão da oferta de vagas [...]”, uma vez que “[...] o acesso pode estar garantido no âmbito formal, mas a permanência poderá ser ameaçada [...]" acaso as condições especiais desse público não sejam respeitadas e ofertadas.

Ainda que o artigo $5^{\circ}$ do Decreto $n^{\circ} 5.626 / 05$ (BRASIL, 2005) determine sobre a formação em nível superior do professor de Libras, seja em um curso bilíngue de Pedagogia ou normal superior, isso não assegura a aprendizagem de conteúdos necessários para a execução de uma educação bilíngue. Em concordância com Lacerda, Albres e Drago (2013) preparar profissionais para uma educação bilíngue ultrapassa o uso da Libras e da modalidade escrita da Língua Portuguesa como línguas de instrução, concebendo um currículo voltado especificamente para a educação de surdos, abrangendo, por exemplo, o ensino da Língua Portuguesa como L2 e as questões culturais e identitárias das comunidades surdas. Segundo as autoras, os cursos desse âmbito, que atualmente circulam no país, ainda estão passíveis de ajustes e avaliação, tendo em vista que são recentes e numericamente pouco expressivos.

Algumas pesquisas já cooperam nesse sentido, tal como a dissertação de Nembri (2011) que observou o cotidiano dos alunos surdos e ouvintes do curso de Pedagogia bilíngue do Ines e concluiu que a Libras ainda não tem sido plenamente valorizada nesse contexto, ou a tese de Albres (2014) que constatou dificuldades de universitários surdos durante o curso de Letras Libras da Ufsc, por exemplo, em obter o material didático integralmente traduzido para a Libras em tempo ágil ou em localizarem campos de estágio em alguns municípios. Ainda assim, como 
essas e outras produções por nós encontradas retratam somente os cursos do Ines e da Ufsc, para trabalhos vindouros, projetamos a necessidade de se estender a análise para as outras IES.

Acrescentaríamos às possibilidades de estudos futuros, o olhar para a inserção profissional dos surdos egressos dos cursos de Pedagogia bilíngue e Letras Libras no mercado de trabalho, pois, de acordo com Magaldi (2011), mesmo diante de maior preparo por meio da formação universitária, muitos surdos ainda enfrentam dificuldades para obter funções e salários compatíveis. Para esse autor, trata-se de uma incessante tentativa de romper com as representações tão naturalizadas sobre o profissional surdo que, durante muito tempo, o aprisionaram em tarefas auxiliares de trabalho.

Ademais, nos alinhamos à Albres (2014), ao entender que a graduação constitui somente no início da formação docente, pois assim como para todos os professores, a formação continuada é essencial, seja por intermédio da formação em serviço, de participações em eventos e, evidentemente, em cursos de pós-graduação ou outras possibilidades. Conforme visto, grande parte dos professores formados no curso de Letras Libras está atuando na educação superior somente com o curso de graduação (SARTURI, 2013). A esse respeito, concordamos com Albres (2014) e Müller (2009), ao assumir que as exigências profissionais têm se tornado cada vez maiores, ou seja, se antes bastava o diploma de um curso de graduação para ingressar na carreira docente, atualmente, a busca tem sido pelos profissionais com especialização, mestrado e até mesmo doutorado. Trata-se de uma situação delicada, pois a exigência de titulações em nível de pós-graduação está relacionada a busca pela (ou a expectativa de) qualidade da educação superior e, ao mesmo tempo, é uma forma de incentivar os surdos a darem continuidade nos seus estudos, alcançando níveis de formação docente mais elevados (ALBRES, 2014). Por outro lado, assim como Rebouças (2009) e Albres (2014) salientam, a exigência de formação e/ou titulação stricto sensu “[...] gera tensão, pois favorece a entrada de professores ouvintes, por vezes sem competência linguística para o ensino da Libras, ou ainda, debates para exigência de níveis mais baixos de formação.” (ALBRES, 2014, p. 58). Logo, a formação continuada para docência da Libras também poderia ser palco de discussão para trabalhos posteriores que se dedicariam a questões como essas e tantas outras que levantamos.

Cumpre destacar que tentamos não emitir julgamentos enérgicos às Ifes, por valorizar a coragem que estas apresentaram ao se desafiarem na oferta de cursos inéditos no país, sendo precursoras e formando os primeiros profissionais graduados no ramo da docência da Libras para o mercado de trabalho. Uma responsabilidade merecedora de crédito e respeito. 
Em suma, daquilo que nos propusemos investigar acreditamos ter alcançado resultados satisfatórios. Nesse percurso, advogamos pela presença de mais educadores surdos na docência da Libras, compreendendo suas implicações políticas, linguísticas, educacionais e identitárias, não apenas na vida do indivíduo surdo, mas em todo seu coletivo. Complementarmente, defendemos que essa docência deve ser fundamentada em cursos de graduação (e pósgraduação), contando com profissionais mais preparados para contribuir efetivamente na mudança de práticas sociais em torno da Libras e da valorização das pessoas surdas como bilíngues. Nossas expectativas são de que os efeitos dessa formação reverberem em novos direcionamentos concernentes ao reconhecimento da surdez como diferença nas instituições educacionais e na sociedade como um todo.

Por fim, com base em nossa pesquisa é possível afirmar que, embora seja assegurado aos sujeitos surdos um conjunto de direitos positivados em leis que garantem o seu acesso aos cursos superiores de formação de professores de Libras, existem inúmeros desafios para sua concretização. Para superá-los, é necessária maior atenção para a redação de textos legais, bem como investimento e fiscalização dos órgãos responsáveis, mas, sobretudo, precisamos encontrar caminhos para desconstruir as representações audistas que insistem em olhar as pessoas surdas, exclusivamente, a partir das lentes da deficiência. 


\section{REFERÊNCIAS}

ALBRES, Neiva Aquino. A educação de alunos surdos no Brasil do final da década 1970 a 2005: análise dos documentos referenciadores. 2005. 129 f. Dissertação (Mestrado em Educação) - Centro de Ciências Humanas e Sociais, Universidade Federal do Mato Grosso do Sul, Campo Grande, 2005.

Relações dialógicas entre professores surdos sobre o ensino de Libras. 2014. 305 f. Tese (Doutorado em Educação Especial) - Centro de Educação e Ciências Humanas, Universidade Federal de São Carlos, São Carlos, 2014.

ALMEIDA FILHO, José Carlos Paes de. Dimensões comunicativas no ensino de línguas. 3. ed. Campinas: Pontes, 2002. 76 p.

ALTENHOFEN, Cléo V. Bases para uma política linguística das línguas minoritárias no Brasil. In: NICOLAIDES, Christine et al. Política e políticas linguísticas. Campinas: Pontes, 2013. p. 93-116.

AMORIM, Joni A.; SILVA, Mariana da Rocha C. Produção de multimídia e acessibilidade em cursos de aprendizagem a distância. Educação Temática Digital, Campinas, v. 10, n. 2, p. 355-372, jun. 2009. Disponível em: 〈http://dx.doi.org/10.20396/etd.v10i2.993〉. Acesso em: 13 maio 2016.

ANDRADE, Alline Nunes. Ecos do silêncio: juízos de surdos no âmbito da formação superior sobre projetos de vida e humilhação nas perspectivas moral e ética. 2012. 295 f. Tese (Doutorado em Psicologia) - Centro de Ciências Humanas e Naturais, Universidade Federal do Espírito Santo, Vitória, 2012.

ASSIS-PETERSON, Ana Antônia de. Como ser feliz no meio de anglicismos: processos transglóssicos e transculturais. Trabalhos em Linguística Aplicada, Campinas, v. 47, n. 2, p. 323-340, jul./dez. 2008.

AVELAR, Thaís Fleury. A formação de identidades culturais no curso de letras-libras por meio da atividade de tradução. Cadernos de Tradução, Florianópolis, v. 2, n. 26, p. 275-289, 2010. Disponível em: <https://periodicos.ufsc.br/index.php/traducao/article/view/21757968.2010v2n26p275>. Acesso em: 3 ago. 2015.

BARBOSA, Mônica de Gois Silva. O mecanismo de coerência na produção escrita de surdos: foco no vestibular 2011 da UFS. 2011. 127 f. Dissertação (Mestrado em Letras) Programa de Pós-Graduação em Letras, Universidade Federal de Sergipe, São Cristóvão, 2011.

BACELLAR, Arnaldo de Oliveira. (1926). A surdo mudez no Brasil (cadeira de hygiene). 134 f. Tese (Doutorado em Medicina) - Faculdade de Medicina de São Paulo, São Paulo. Rio de Janeiro: Ines, 2013. (Série histórica do Instituto Nacional de Educação de Surdos, 6).

BAGNO, Marcos. Preconceito Linguístico: o que é, como se faz. São Paulo: Edições Loyola, 1999. 148 p. 
BARDIN, Laurence. Análise de conteúdo. Tradução de Luis Antero Reto, Augusto Pinheiro. França: Press Universitaires de France, 1977. 229 p.

BARNES, Colin. Discapacidad, política y pobreza en el contexto del "mundo mayoritario". Política y Sociedad, Madrid/Espanha, v. 47, n. 1, p. 11-25, 2010.

BAUER, Martin W. Análise de conteúdo clássica: uma revisão. In: BAUER, Martin W.; GASKELL, George (ed.). Pesquisa qualitativa com texto, imagem e som: um manual prático. Tradução de Pedrinho A. Guareschi. Petrópolis: Vozes, 2002. p. 189-217.

BEAUCHAMP, Tom L.; CHILDRESS, James F. Princípios de ética biomédica. Tradução de Luciana Pudenzi. São Paulo: Loyola, 2002. 574 p.

BEHARES, Luis Ernesto. Rethinking the deaf child's relation to language. Caderno de Estudos Linguísticos, Campinas, v. 33, p. 61-66, jul./dez. 1997.

Línguas e identificações: as crianças surdas entre o "sim" e o "não". In: SKLIAR, Carlos (Org.). Atualidade da educação bilíngue para surdos: interfaces entre pedagogia e linguística. 5 ed. Porto Alegre: Mediação, 2015. p. 131-147.

BHABHA, HOMI K. O local da cultura. Tradução de Myriam Ávila, Eliana Lourenço de Lima Reis e Gláucia Renate Gonçalves. 4 ed. Belo Horizonte: Editora UFMG, 2007. 395 p.

BISOL, Cláudia Alquati et al. Estudantes surdos no ensino superior: reflexões sobre a inclusão. Cadernos de Pesquisa, São Paulo, v. 40, n. 139, p. 147-172, abr. 2010. Disponível em: 〈http://www.scielo.br/pdf/cp/v40n139/v40n139a08.pdf>. Acesso em: 10 nov. 2014.

BOBBIO, Norberto. A era dos direitos. Tradução Carlos Nelson Coutinho. Rio de Janeiro: Campus, 1992. $271 \mathrm{p}$.

BONETI, Lindomar Wessler. Exclusão e inclusão social - teoria e método. Contexto e Educação, Ijuí, v. 21, n. 75 p. 187-206, jan./jun. 2006. Disponível em:

<https://www.revistas.unijui.edu.br/index.php/contextoeducacao/issue/view/79>. Acesso em: 3 out. 2016.

BRANDÃO, Zaia. Pesquisa em educação: conversas com pós-graduandos. Rio de Janeiro: PUC-RJ / Loyola, 2002. 148 p.

BRASIL. Congresso Nacional. Constituição da República Federativa do Brasil de 1988. Brasília, DF: Senado, 1988. Disponível em:

<http://www.planalto.gov.br/ccivil_03/Constituicao/ConstituicaoCompilado.htm>. Acesso em: 29 jul. 2015.

Decreto no 3.298, de 20 de dezembro de 1999. Regulamenta a Lei $n^{\circ} 7.853$, de 24 de outubro de 1989, dispõe sobre a política nacional para a integração da pessoa portadora de deficiência, consolida as normas de proteção, e dá outras providências. Brasília, DF, 1999. Disponível em: <http://www.planalto.gov.br/ccivil_03/decreto/d3298.htm>. Acesso em: 24 mar. 2016. 
Decreto $n^{\circ} 5.626$, de 22 de dezembro de 2005. Regulamentada a Lei ${ }^{\circ} 10.436$, de 24 de abril de 2002, que dispõe sobre a Língua Brasileira de Sinais - Libras, e o art. 18 da Lei no 10.098, de dezembro de 2000. Diário Oficial da União, Brasília, DF, 23 dez. 2005. Seção 1, p. 28-30.

Decreto $\mathrm{n}^{\circ}$ 5773, de 9 de maio de 2006a. Dispõe sobre o exercício das funções de regulação, supervisão e avaliação de instituições de educação superior e cursos superiores de graduação e sequenciais no sistema federal de ensino. Diário Oficial da União, Brasília, DF, 10 maio 2006. Seção 1, p. 6-10.

Decreto $\mathbf{n}^{0}$ 6.094, de 24 de abril de 2007a. Dispõe sobre a implementação do Plano de Metas Compromisso Todos pela Educação, pela União Federal, em regime de colaboração com municípios, Distrito Federal e estados, e a participação das famílias e da comunidade, mediante programas e ações de assistência técnica e financeira, visando a mobilização social pela melhoria da qualidade da educação básica. Brasília, DF, 2007. Disponível em: <http://www.planalto.gov.br/ccivil_03/_ato2007-2010/2007/decreto/d6094.htm>. Acesso em: 3 out. 2016.

Decreto $\mathbf{n}^{\mathbf{0}}$ 6.755, de 29 de janeiro de 2009. Institui a política nacional de formação de profissionais do magistério da educação básica, disciplina a atuação da coordenação de aperfeiçoamento de pessoal de nível superior - Capes no fomento a programas de formação inicial e continuada, e dá outras providências. Brasília, DF, 2009b. Disponível em: <http://www.planalto.gov.br/ccivil_03/_ato2007-2010/2009/decreto/d6755.htm>. Acesso em: 3 out. 2016.

Lei no 9.394, de 20 de dezembro de 1996. Estabelece diretrizes e bases da educação nacional. Brasília, DF, 1996. Disponível em: <http://www.planalto.gov.br/CCIVIL_03/leis/L9394.htm>. Acesso em: 15 ago. 2015.

Lei $\mathrm{n}^{0} 10.436$, de 24 de abril de 2002. Dispõe sobre a língua brasileira de sinais Libras e dá outras providências. Diário Oficial da União, Brasília, DF, 25 abr. 2002. Seção 1, p. 23.

Lei $\mathrm{n}^{\circ} 12.711$, de 29 de agosto de 2012. Dispõe sobre o ingresso nas universidades federais e nas instituições federais de ensino técnico de nível médio e dá outras providências. Diário Oficial da União, Brasília, DF, 30 ago. 2012a. Seção 1, p. 1-2.

Lei $\mathrm{n}^{\circ} 12.796$, de 4 de abril de 2013a. Altera a Lei $\mathrm{n}^{\circ}$ 9.394, de 20 de dezembro de 1996, que estabelece as diretrizes e bases da educação nacional, para dispor sobre a formação dos profissionais da educação e dar outras providências. Diário Oficial da União, Brasília, DF, 5 abr. 2013. Seção 1, p. 1.

Lei n ${ }^{\circ} 13.005$, de 25 de junho de 2014. Aprova o plano nacional de educação - PNE e dá outras providências. Diário Oficial da União, Brasília, DF, 26 jun. 2014. Edição extra, Seção 1, p. 1-7.

Ministério da Educação. Parecer no 04, de 16 de fevereiro de 2000. Diretrizes operacionais para a educação infantil. Brasília, DF, 2000. Disponível em: <http://portal.mec.gov.br/cne/arquivos/pdf/2000/pceb004_00.pdf>. Acesso em: 3 out. 2016. 
Parecer $\mathbf{n}^{\mathbf{0}}$ 15, de 4 de agosto de 2009. Consulta sobre a categoria profissional do professor de curso livre e educação profissional técnica de nível médio, com base no plano nacional de educação. Brasília, DF, 2009a. Disponível em:

<http://portal.mec.gov.br/dmdocuments/pcp015_09_homolog.pdf>. Acesso em: 15 ago. 2015.

Portaria $\mathrm{n}^{\mathrm{o}} 3.284$, de 7 de novembro de 2003. Dispõe sobre requisitos de

acessibilidade de pessoas portadoras de deficiências, para instruir os processos de autorização e de reconhecimento de cursos, e de credenciamento de instituições. Diário Oficial da União, Brasília, DF, 11 nov. 2003, Seção 1, p. 12.

Portaria normativa $n^{\circ} 16$, de 27 de julho de 2011. Dispõe sobre certificação no nível de conclusão do ensino médio ou declaração de proficiência com base no exame nacional de ensino médio - Enem. Diário Oficial da União, Brasília, DF, 28 jul. 2011a. Seção 1, p. 8.

Ministério da Educação. Instituto Nacional de Educação de Surdos. Edital no 4, de 19 de janeiro de 2006 - Concurso/Vestibular 2006/01, de 23 de jan. 2006b. Diário Oficial da União, Brasília, DF, 23 jan. 2006. Seção 3, p. 23-27.

Edital $n^{\circ} 22$, de 29 de novembro de 2006 - Concurso Vestibular ${ }^{\circ} 1 / 2007$, de 29 nov. 2006c. Diário Oficial da União, Brasília, DF, 29 nov. 2006. Seção 3, p. 48.

. Edital $n^{\circ} 5$, de 6 de dezembro de 2007 - Concurso/Vestibular 2008/01, de 10 dez. 2007b. Diário Oficial da União, Brasília, DF, 10 dez. 2007. Seção 3, p. 37-41.

Edital $n^{\circ} 11$, de 22 de outubro de 2008 - Concurso Vestibular 2009/01, de 23 out. 2008. Diário Oficial da União, Brasília, DF, 23 out. 2008. Seção 3, p. 43-44.

Edital no 8/2009 - Concurso de acesso ao curso de graduação bilíngue de Pedagogia do Ines - 2010, de 25 nov. 2009c. Diário Oficial da União, Brasília, DF, 25 nov. 2009. Seção 3, p. 78-79.

Edital n ${ }^{\circ}$ 3/2011 - Concurso de acesso ao curso bilíngue de graduação de Pedagogia do Ines - 2012.1, de 19 dez. 2011b. Diário Oficial da União, Brasília, DF, 19 dez. 2011. Seção 3, p. 74-75.

Edital no 6/2012 - Concurso de acesso ao curso bilíngue de graduação em Pedagogia do Ines - 2013.1, de 8 ago. 2012. Diário Oficial da União, Brasília, DF, 8 ago. 2012b. Seção 3 , p. 58-59.

Ministério da Educação e do Desporto. Secretaria de Educação Especial. Educação especial: deficiência auditiva. Brasília: MEC, 1997. (Atualidades pedagógicas, 4).

Ministério da Educação. Secretaria de Educação Especial. Convenção sobre os direitos das pessoas com deficiência / ONU - ratificada pelo Decreto n ${ }^{\circ}$ 6.949/2009. In: BRASIL. Marcos político-legais da educação especial na perspectiva da educação inclusiva. Brasília: MEC, 2010a, p. 31-68.

Nota técnica $n^{\circ} 08$ / 2011. In: BRASIL. Ministério da Educação. Orientações para a implementação da política de educação especial na perspectiva da educação inclusiva. Brasília, DF: MEC, 2015b, p. 117-128. Disponível em: 
$<$ http://portal.mec.gov.br/index.php?option=com_docman\&view=download\&alias=17237secadi-documento-subsidiario-2015\&Itemid=30192>. Acesso em 3 out. 2016.

Ministério da Justiça e da Cidadania. Secretaria Especial dos Direitos da Pessoa com Deficiência. Observatório do Viver sem Limite. Brasília, DF, 2016b. Disponível em: $<$ http://www.sdh.gov.br/assuntos/pessoa-com-deficiencia/observatorio/acesso-aeducacao/educacao-bilingue >. Acesso em 25 jul. 2016.

Ministério da Educação. Programa Incluir. Brasília, DF, 2016a. Disponível em: <http://portal.mec.gov.br/programa-incluir〉. Acesso em: 10 ago. 2016.

Referenciais curriculares nacionais dos cursos de bacharelado e licenciatura. Brasília, DF: Ministério da Educação, Secretaria de Educação Superior, 2010b. Disponível em: <http://www.dca.ufrn.br/ adelardo/PAP/ReferenciaisGraduacao.pdf >. Acesso em: 3 de out. 2016.

. Ministério da Educação. Sistema e-MEC. Brasília, DF, 2015a. Disponível em: <http://emec.mec.gov.br/>. Acesso em: 15 jul. 2015.

Ministério da Educação. Sisu - sistema de seleção unificada. Brasília: MEC, 2016c. Disponível em: <http://SISU.mec.gov.br/como-funciona〉. Acesso em: 26 jul. 2016.

Viver sem limite: plano nacional dos direitos da pessoa com deficiência. Brasília: Secretaria de Direitos Humanos da Presidência da República (SDH/PR) / Secretaria Nacional de Promoção dos Direitos da Pessoa com Deficiência (SNPD), 2013 b.

BRITO, Fábio Bezerra de. O movimento social surdo e a campanha pela oficialização da língua brasileira de sinais. 2013. 275 f. Tese (Doutorado em Educação) - Faculdade de Educação, Universidade de São Paulo, São Paulo, 2013.

BUERES, Teresa Cristina Hitomi Kikuchi. Um estudo sobre a formação linguística dos instrutores de libras em Palmas - Tocantins. 2010. 120 f. Dissertação (Mestrado em Linguística) - Centro de Ciências Humanas Letras e Artes, Universidade Federal da Paraíba, João Pessoa, 2010.

CAMPOS, Mariana de Lima Isaac Leandro. Educação inclusiva para surdos e políticas vigentes. In: LACERDA, Cristina Broglia Feitosa de; SANTOS, Lara Ferreira dos. (Org.). Tenho um aluno surdo, e agora? Introdução a Libras e educação de surdos. São Carlos: Edufscar, 2013. p. 37-61.

CARVALHO, Paulo Vaz de. Breve história dos surdos: no mundo e em Portugal. Lisboa: Surd'Universo, 2007.

CASTEL, Robert. A discriminação negativa. Cidadãos ou autóctones? Tradução de Francisco Morás. 2. ed. Petrópolis/RJ: Vozes, 2011. 136 p.

CASTRO, Mariana Gonçalves Ferreira de. A representação social da Libras em surdos bilíngues. 2012. 120 f. Dissertação (Mestrado em Educação) - Programa de Pós-Graduação em Educação, Universidade Estácio de Sá, João Pessoa, 2012. 
CAVALCANTI, Marilda Couto. Estudos sobre educação bilíngue e escolarização em contextos de minorias linguísticas no Brasil. Delta, São Paulo, v. 15, n. especial, p. 385-417, 1999. Número especial.

Multilinguismo, transculturalismo e o (re)conhecimento de contextos minoritários, minoritarizados e invisibilizados: o que isso tem a ver com a formação de professores e com professores em serviço? In: MAGALHÃES, Maria Cecília C., FIDALGO, Sueli Salles (Org.). Questões de método e de linguagem na formação docente. Campinas: Mercado de Letras, 2011. p. 171-185.

CERNY, Roseli Zen; VILHALVA, Shirley. A gestão pedagógica nos cursos de letras libras. In: QUADROS, Ronice Müller (Org.). Letras Libras: ontem, hoje e amanhã. Florianópolis: Edufsc, 2014. p. 37-54.

CÉSAR, América Lúcia, CAVALCANTI Marilda Couto. Do singular para o multifacetado: o conceito de língua como caleidoscópio. In: CAVALCANTI, Marilda Couto; BORTONIRICARDO Stella Maris (Org.). Transculturalidade, linguagem e educação. Campinas: Mercado de Letras, 2007. p. 45-65.

CHAVES, Adriana Di Donato. Protocolo de avaliação do desempenho da escrita de palavras por aprendizes surdos. 2012. $190 \mathrm{f}$. Tese (Doutorado em Linguística) - Centro de Ciências Humanas, Letras e Artes, Universidade Federal da Paraíba, João Pessoa, 2012.

CHOI, Daniel et al. Libras: conhecimento além dos sinais. São Paulo: Pearson Prentice Hall, 2011. 144 p.

CIRIACO, Douglas. A história da conexão. São Paulo: TECMUNDO, 06 ago. 2009. Disponível em: 〈http://www.tecmundo.com.br/banda-larga/2543-a-historia-da-conexao.htm>. Acesso em: 4 ago. 2016.

CONTIERI, Suzane de Mello. Percepção de auto-estima e qualidade de vida do jovemadulto surdo universitário. 2007. 107 f. Dissertação (Mestrado em Psicologia da Saúde) Faculdade de Psicologia e Fonoaudiologia, Universidade Metodista de São Paulo, São Bernardo do Campo, 2007.

COORDENAÇÃO DE APERFEIÇOAMENTO DE PESSOAL DE NÍVEL SUPERIOR. Plano Nacional de formação de professores da educação básica - Parfor. Brasília: Capes, 2015. Disponível em: <http://www.capes.gov.br/educacao-basica/parfor>. Acesso em 26 jul. 2016.

COSTA, Aparecida Maria de Brito et al. Curso de pedagogia a distância: formação de professores surdos e ouvintes em Florianópolis. Espaço: Informativo Técnico Científico do Ines, Rio de Janeiro, n. 23, p. 34-38, jan./jun. 2005.

COSTA, Juliana Pellegrinelli Barbosa. O surdo e as posições sujeito ontem e hoje: falta, excesso ou diferença. 2009. 119 f. Dissertação (Mestrado em Linguística Aplicada) - Instituto de Estudos da Linguagem, Universidade Estadual de Campinas, Campinas, 2009. 
COSTA, Simone de Fátima Saldanha Carneiro. As representações sociais dos participantes do curso letras-libras/EAD sobre surdos. 2011. 134 f. Dissertação (Mestrado em Educação) Faculdade de Educação, Universidade de Brasília, Brasília, 2011.

COX, Maria Inês Pagliarini; ASSIS-PETTERSON, Ana Antônia de. Transculturalidade e transglossia: para compreender o fenômeno das fricções contemporâneas sem nostalgia. In: CAVALCANTI, Marilda do Couto; BORTONI-RICARDO, Stella Maris. (Orgs.).

Transculturalidade, linguagem e educação. Campinas: Mercado de Letras, 2007. p.23-44.

CRUZ, José Ildon Gonçalves da; DIAS, Tárcia Regina da Silveira. Trajetória escolar do surdo no ensino superior: condições e possibilidades. Revista Brasileira Educação Especial, Marília, v. 15, n. 1, p. 55-80, abr. 2009. Disponível em: <http://dx.doi.org/10.1590/S141365382009000100006>. Acesso em: 10 nov. 2014.

DAROQUE, Samantha Camargo. Alunos surdos no ensino superior: uma discussão necessária. 2011. 86 f. Dissertação (Mestrado em Educação) - Faculdade de Ciências Humanas, Universidade Metodista de Piracicaba, Piracicaba, 2011.

DAROQUE, Samantha Camargo; QUEIROZ, Guilherme Alves de. Inclusão de surdos no ensino superior. O que tem de bilíngue? In: ALBRES, Neiva de Aquino; NEVES, Sylvia Lia Grespan (Org.). Libras em estudo: política educacional. São Paulo: Feneis, 2013. p. 139163.

DECLARAÇÃO UNIVERSAL DOS DIREITOS LINGUÍSTICOS. In: OLIVEIRA, Gilvan Müller de (Org.). Declaração universal dos direitos linguísticos: novas perspectivas em política linguística. Campinas: Mercado de Letras / Associação de Leitura do Brasil; Florianópolis: IPOL, 2003. p. 13-46.

DENZIN, Norman K.; LINCOLN, Yvonna S. Introdução: a disciplina e a prática da pesquisa qualitativa. In: DENZIN, Norman K.; LINCOLN, Yvona S. O planejamento da pesquisa qualitativa: teorias e abordagens. 2. ed. Tradução Sandra Regina Netz. Porto Alegre: Artmed, 2006. p. 15-41.

DESLAURIERS, Jean Pierre; KÉRISIT, Michèle. O delineamento de pesquisa qualitativa. In: POUPART, Jean et al. (Org.). A pesquisa qualitativa: enfoques epistemológicos e metodológicos. Tradução de Ana Cristina Nasser. Petrópolis: Vozes, 2008. p. 127-153. (Coleção Sociologia).

DHANDA, Amita. Construindo um novo léxico dos direitos humanos: convenção sobre os direitos das pessoas com deficiências. Revista Internacional de Direitos Humanos. São Paulo, v. 5, n. 8, p. 42-59, jun. 2008.

DINIZ, Debora. Deficiência e políticas sociais - entrevista com Colin Barnes - Interview with Colin Barnes - Debora Diniz, SER social, Brasília, v. 15, n, 32, jan./jul. 2013.

DORNELLES, Ana Cláudia Tenório; ZANELLA, Josiane. A formação do instrutor surdo e o mercado de trabalho: uma inter-relação necessária. Revista Educação Especial, Santa Maria, v. 21, n. 31, p. 95-104, 2008. 
DUBET, François. O que é uma escola justa? Cadernos de Pesquisa, São Paulo, v. 34, n. 123, p. 539-555, 2004.

FARIA, Juliana Guimarães. Formação, profissionalização e valorização do professor surdo: reflexões a partir do Decreto 5.626/2005. Revista Brasileira de Educação Especial, Marília, v. 17, n. 1, p. 87-100, 2011.

FAVORITO, Wilma. "O difícil são as palavras": representações de/sobre estabelecidos e outsiders na escolarização de jovens e adultos surdos. 2006. $264 \mathrm{f}$. Tese (Doutorado em Linguística Aplicada) - Instituto de Estudos da Linguagem, Universidade Estadual de Campinas, 2006.

\section{FEDERAÇÃO NACIONAL DE EDUCAÇÃO E INTEGRAÇÃO DOS SURDOS. A} educação que nós surdos queremos. Porto Alegre: Ufrgs, 1999.

FELIPE, Tânia Amara. Introdução à Gramática de LIBRAS. In: BRASIL, Ministério da Educação e do Desporto. Educação especial: língua brasileira de sinais. Brasília: Secretaria de Educação Especial, 1997. v. 3. p. 81-123. (Série Atualidades Pedagógicas).

FERNANDES, Eulália. Linguagem e surdez. Porto Alegre: Artmed, 2003. 155 p.

FERREIRA, Aurélio Buarque de Holanda. Novo dicionário da língua portuguesa. 2. ed. Rio de Janeiro: Nova Fronteira, 1986. 1838 p.

FERREIRA-BRITO, Lucinda. Integração social do surdo. Trabalhos em linguística aplicada, Campinas, v. 7, p. 13-22, 1986.

FONSECA, Maria Hemília. Direto ao trabalho: um direito fundamental no ordenamento jurídico brasileiro. 2006. 373 f. Tese (Doutorado em Direito) - Faculdade de Direito, Pontifícia Universidade Católica de São Paulo, São Paulo, 2006.

FRANCO, Monique. Educação superior bilíngue para surdos: o sentido da política inclusiva como espaço da liberdade: primeiras aproximações. Revista Brasileira de Educação Especial, Marília, v. 15, n. 1, p. 15-30, jan. 2009.

FRANÇOSO, Maria de Fátima de Campos. Família e surdez: algumas considerações aos profissionais que trabalham com famílias. In: SILVA, Ivani Rodrigues; KAUCHAKJE, Samira; GESUELLI, Zilda Maria (Org.). Cidadania, surdez e linguagem: desafios e realidades. São Paulo: Plexus, 2003. p. 77-88.

GATTI, Bernadete Angelina; BARRETO, Elba Siqueira de Sá. (Coord.). Professores do Brasil: impasses e desafios. Brasília: Unesco, 2009. 294 p.

GESSER, Audrei. Um olho no professor e outro na caneta: ouvintes aprendendo a Língua Brasileira de Sinais. 2006. 217 f. Tese (Doutorado em Linguística Aplicada) - Instituto de Estudos da Linguagem, Universidade Estadual de Campinas, Campinas, 2006.

Libras? Que língua é essa? Crenças e preconceitos em torno da língua de sinais e da realidade surda. São Paulo: Parábola, 2009. 87 p. (Série Estratégias de Ensino, 14). 
$187 \mathrm{p}$.

O ouvinte e a surdez: sobre ensinar e aprender a Libras. São Paulo: Parábola, 2012.

GIANINI, Eleny. Professores surdos de libras: A centralidade de ambientes bilíngues em sua formação. 2012. 203 f. Tese (Doutorado em Educação) - Centro de Educação, Universidade Federal do Rio Grande do Norte, Natal, 2012.

GIL, Antônio Carlos. Como elaborar projetos de pesquisa. 4. ed. São Paulo: Atlas, 2002. $175 \mathrm{p}$.

GOES, Camila Guedes Guerra. Curso de letras/libras: análise das experiências dos alunos surdos no ensino a distância do Rio Grande do Sul. 2010. 115 f. Dissertação (Mestrado em Educação) - Faculdade de Educação, Universidade do Rio Grande do Sul, Porto Alegre, 2010.

GONZALEZ, Roseli Kubo. Educação especial e processos de encaminhamento para sala de recursos: relações de gênero cor/raça. 2013. 258 f. Tese (Doutorado em Educação) Faculdade de Educação, Universidade de São Paulo, São Paulo, 2013.

GOULARTE, Ravele Bueno. Acesso e permanência no ensino superior: estratégias de governamento da conduta de alunos surdos incluídos. 2014. 107 f. Dissertação (Mestrado em Educação) - Centro de Educação, Universidade Federal de Santa Maria, Santa Maria, 2014.

HALL, Stuart. A identidade cultural na pós-modernidade. Tradução Tomaz Tadeu Silva, Guacira Lopes Louro. Rio de Janeiro: DP\&A, 1998. 102 p.

Quem precisa de identidade? In: HALL, Stuart; WOODWARD, Kathryn; SILVA, Tomaz Tadeu da (Org.). Identidade e diferença: a perspectiva dos estudos culturais. Petrópolis: Vozes, 2000. p.103-133. (Série Educação pós-crítica).

HAMEL, Rainer Enrique. Determinantes sociolinguísticas de la educación indígena bilingue. Trabalhos em linguística aplicada, Campinas, v. 14, n. 3, p. 15-65, jul./dez. 1989.

INSTITUTO BRASILEIRO DE GEOGRAFIA E ESTATÍSTICA. Banco de dados estados@. Brasília: IBGE, 2010. Disponível em:

<http://www.ibge.gov.br/estadosat/temas.php?sigla=ap\&tema=censodemog2010_defic >. Acesso em: 30 jul. 2015.

INSTITUTO FEDERAL DE GOIÁS. Edital n. 155 (2014-2). Goiânia: IFG, 14 nov. 2014. 55 p. Disponível em: <http://vestibular.cefetgo.br/downloads/editalvest_ped_bilingue_17_11_2014.pdf >. Acesso em: 29 jun. 2015.

INSTITUTO NACIONAL DE EDUCAÇÃO DE SURDOS. Prolibras. Rio de Janeiro: INES, 2015. Disponível em: <http://www.ines.gov.br/index.php/prolibras-4>. Acesso em: 26 ago. 2015.

Edital n. 18 (2014-2). Rio de Janeiro: Ines, 2014, 18 p. Disponível em:

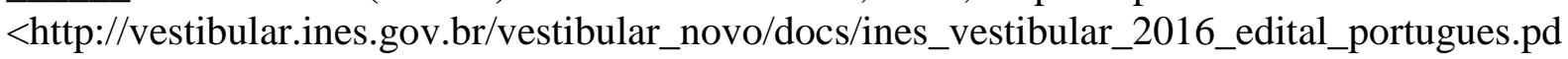
f>. Acesso em: 16 jun. 2016. 
INSTITUTO NACIONAL DE ESTUDOS E PESQUISAS EDUCACIONAIS ANÍSIO TEIXEIRA. Prolibras. Brasília: INEP, 2011.Disponível em:

<http://portal.inep.gov.br/prolibras1>. Acesso em: 15 ago. 2015.

JANNUZZI, Gilberta. A luta pela educação do deficiente mental no Brasil. 2. ed. Campinas: Autores Associados, 1992. 123 p.

KERSTENETZKY, Célia Lessa. Políticas sociais: focalização ou universalização? Revista de Economia Política. São Paulo, v. 40, n. 4, p. 564-574, out./dez. 2006. Disponível em: <http://academico.direitorio.fgv.br/ccmw/images/7/72/Celia.pdf >. Acesso em: 5 jan. 2015.

KLEIN, Madalena; FORMOZO, Daniele de Paula. Gênero e surdez. Reflexão e Ação, Santa Cruz do Sul, v. 15, n. 1, p. 100-112, 2007. Disponível em:

<http://online.unisc.br/seer/index.php/reflex/article/view/225/172>. Acesso em: 20 jul. 2015.

KLIMSA, Bernardo Luís Torres. Narrativas de alunos universitários sobre o professor surdo e o ensino de Libras. 2013. 144 f. Dissertação (Mestrado em Ciências da Linguagem) - Programa de Pós-Graduação em Ciências da Linguagem, Universidade Católica de Pernambuco, Recife, 2013.

KOVÁCS, Daniela Ferrari. Direito fundamental ao trabalho, muito além das cotas: o resgate da cidadania das pessoas com deficiência. Revista Científica Virtual da Escola Superior de Advocacia da OAB-SP, São Paulo, v. 5, n. 20, p. 54-65, 2015.

KUMADA, Kate Mamhy Oliveira. "No começo ele não tem língua nenhuma, ele não fala, ele não tem Libras, né?": representações sobre línguas de sinais caseiras. 2012. 156 f. Dissertação (Mestrado em Linguística Aplicada) - Instituto de Estudos da Linguagem, Universidade Estadual de Campinas, Campinas, 2012.

KUMADA, Kate Mamhy Oliveira; CAVALCANTI, Marilda do Couto. "Ele não tem língua nenhuma": representações sobre as línguas de sinais caseiras. In: LIPPE; Eliza Marcia Oliveira; ALVES, Fábio de Souza (Org.). Educação para surdos no Brasil: desafios e perspectivas para o novo milênio. Curitiba: CRV, 2014. p. 37-54.

KUMADA, Kate Mamhy Oliveira et al. Desafios para a tradução de um livro didático de ciências com uso de avatares expressivos. In: CENTRO DE ENSINO, PESQUISA E EXTENSÃO SOBRE EDUCAÇÃO DE SURDOS E LIBRAS, 1., 2015, São Paulo. Anais... São Paulo: USP, 2015, p. 46-51.

KUMADA, Kate Mamhy Oliveira; SILVA, Ivani Rodrigues. Algumas reflexões sobre livros didáticos de ensino de português como segunda língua para surdos. In: VALLE, Luiza Elena Leite Ribeiro (Org.). Desenvolvimento com competência em aprendizagem: reunindo conhecimentos interdisciplinares. São Paulo: Scortecci, 2016. p. 135-145.

LACERDA, Cristina Boglia Feitosa de.; ALBRES, Neiva de Aquino; DRAGO, Silvana Lucena dos Santos. Política para uma educação bilíngue e inclusiva a alunos surdos no município de São Paulo. Educação e pesquisa, São Paulo, v. 39, n. 1, p. 65-80, jan./mar. 2013. 
LACERDA, Cristina Boglia Feitosa de; SANTOS; Lara Ferreira dos; CAETANO, Juliana Fonseca. Estratégias metodológicas para o ensino de alunos surdos. In: LACERDA, Cristina Boglia Feitosa de; SANTOS, Lara Ferreira dos. (Org.). Tenho um aluno surdo, e agora? Introdução à Libras e educação de surdos. São Carlos: Edufscar, 2013. p. 185-200.

LAMB, Catia Regina Zuge. Universidade Federal de Santa Maria: um lugar para os surdos. 2013. 159 f. Dissertação (Mestrado em Geografia e Geociências) - Universidade Federal de Santa Maria, Santa Maria, 2013.

LANE, Harlan. The deaf experience: classics in language and education. England: Harvard University Press, 1984. 221 p.

LE GOFF, Jacques. História e memória. Tradução de Bernardo Leitão et al. 5. ed. Campinas: Unicamp, 2003. 554 p.

LEITE, Tarcísio de Arantes. O ensino de segunda língua com foco no professor: história oral de professores surdos de língua de sinais brasileira. 2004. 250 f. Dissertação (Mestrado em Letras) - Faculdade de Filosofia, Letras e Ciências Humanas, Universidade de São Paulo, São Paulo, 2004.

LIMA, Maria do Socorro Correia. Surdez, bilinguismo e inclusão: entre o dito, o pretendido e o feito. 2004. 261 f. Tese (Doutorado em Linguística Aplicada) - Instituto de Estudos da Linguagem, Universidade Estadual de Campinas, 2004.

LIMA, Priscila Escanfella Alves de. O acesso e permanência de indivíduos surdos no ensino superior. 2012. 117 f. Dissertação (Mestrado em Educação) - Faculdade de Educação, Pontifícia Universidade Católica de São Paulo, São Paulo, 2012.

LINS, Danielle Coelho. Português como segunda língua para surdos (PL2S): o emprego do pronome relativo "que" em textos acadêmicos. 2011. 99 f. Dissertação (Mestrado em Letras ) - Departamento de Letras, Pontifícia Universidade Católica do Rio de Janeiro, Rio de Janeiro, 2011.

LODI, Ana Cláudia Balieiro. Ensino de língua portuguesa como segunda língua para surdos: impacto na educação básica. In: LACERDA, Cristina Broglia Feitosa de; SANTOS, Lara Ferreira dos. (Org.). Tenho um aluno surdo, e agora? Introdução a Libras e educação de surdos. São Carlos: Edufscar, 2013. p. 165-183.

LOPES, Maura Corcini. Surdez \& Educação. 2. ed. Belo Horizonte: Autêntica, 2011. 102 p. (Coleção Temas e Educação, 5).

LUCKESI, Cipriano Carlos. Avaliação da aprendizagem: estudos e proposições. 19 ed. São Paulo: Cortez, 2008. 272 p.

LÜDKE, Menga; ANDRÉ, Marli Elisa Dalmazo Afonso de. Pesquisa em educação: abordagens qualitativas. São Paulo: EPU, 1986. 99 p. (Temas Básicos de Educação e Ensino).

LUNARDI, Márcia Lise. Cartografando estudos surdos: currículo e relações de poder. In: SKLIAR, Carlos (Org.). A surdez: um olhar sobre as diferenças. 8. ed. Porto Alegre: Mediação, 2016. p. 155-165. 
MACHADO, Paulo Cesar. Diferença cultural e educação bilíngue: as narrativas dos professores surdos sobre questões curriculares. 2009. 164 f. Tese (Doutorado em Educação) Centro de Ciências da Educação, Universidade Federal de Santa Catarina, Florianópolis, 2009.

MAGALDI, José Carlos Miraglia. Surdez e inserção profissional: representações sociais de universitários surdos. 2011. 91 f. Dissertação (Mestrado em Educação) - Programa de PósGraduação em Educação, Universidade Estácio de Sá, Rio de Janeiro, 2011.

MAHER, Terezinha Machado. Sendo índio em português. In. SIGNORINI, Inês (Org.). Língua(gem) e identidade: elementos para uma discussão no campo aplicado. Campinas: Mercado de Letras, 1998. p. 155-138.

Do casulo ao movimento: a suspensão das certezas na educação bilíngue e intercultural. In: CAVALCANTI, Marilda Couto; BORTONI-RICARDO; Stella Maris (Org.). Transculturalidade, linguagem e educação. Campinas: Mercado de Letras, 2007. p. 67-96.

Ecos de resistência: políticas linguísticas e línguas minoritárias no Brasil. In: NICOLAIDES, Christine et al. Política e políticas linguísticas. Campinas: Pontes, 2013. p. 117-134.

MANDELBLATT, Janete. Políticas públicas, (des)igualdade de oportunidades e ampliação da cidadania no Brasil: o caso da educação de surdos (1990-2013). 2014. 264 f. Tese (Doutorado em Ciência Política) - Instituto de Ciências Humanas e Filosofia, Universidade Federal Fluminense, Niterói, 2014.

MANENTE, Milena Valelongo; RODRIGUES, Olga Maria Piazentin Rolim; PALAMIN, Maria Estela Guadagnuci. Deficientes auditivos e escolaridade: fatores e diferenciais que possibilitam o acesso ao ensino superior. Revista Brasileira de Educação Especial, Marília, v. 13, n. 1, p. 27-42, jan./abr. 2007.

MARINHO, Margot Latt. O ensino da biologia: o intérprete e a geração de sinais. 2007. 144 f. Dissertação (Mestrado em Linguística) - Instituto de Letras, Universidade de Brasília, Brasília, 2007.

MARTIN-JONES, Marilyn; ROMAINE, Suzanne. Semilingualism: a half baked theory of communicative competence. Applied Linguistics, Oxford, v. 7, n. 1, 1986, p. 27-38.

MARTINS, Diléia A.; LEITE, Lúcia P.; LACERDA, Cristina Boglia Feitosa de. Políticas públicas para acesso de pessoas com deficiência ao ensino superior brasileiro: uma análise de indicadores educacionais. Revista Ensaio: avaliação e políticas públicas em educação, Rio de Janeiro, v. 23, n. 89, p. 984-1014, out./dez. 2015.

MASON, Jennifer. Qualitative researching. London: Sage, 1996. 223 p.

McCLEARY, Leland. Sociolinguística. Florianópolis: Ufsc, 2009. 59 p. Disponível em: <http://www.libras.ufsc.br/colecaoLetrasLibras/eixoFormacaoBasica/sociolinguistica/assets/5 47/TEXTO-BASE_Sociolinguistica.pdf>. Acesso em: 3 ago. 2015. 
McCLEARY, Leland; VIOTTI, Evani. Língua e gesto em línguas sinalizadas. Veredas Revista de Estudos Linguísticos. Juiz de Fora, v. 15, n. 1, p. 289-304, 2011.

MENEZES DE SOUZA, Lynn Mario T. Hibridismo e tradução cultural em Bhabha. In: ABDALA JÚNIOR, Benjamin. (Org). Margens da cultura: mestiçagem, hibridismo \& outras misturas. São Paulo: Boitempo Editorial, 2004. p. 113-133.

Cultura, língua e emergência dialógica. Letras e Letras, Uberlândia, v. 26, n. 2, p. 289-306, jul./dez. 2010.

MESQUITA, Leila Santos de. O acesso do surdo ao ensino superior: limites e avanços das políticas educacionais de inclusão. 2013. 90 f. Dissertação (Mestrado em Educação) - Centro de Educação, Universidade Federal da Paraíba, João Pessoa, 2013.

MICHAELIS MODERNO DICIONÁRIO DE LÍNGUA PORTUGUESA. São Paulo: Melhoramentos, 2009. Disponível em: <http://michaelis.uol.com.br/>. Acesso em: 16 ago. 2015.

MIRANDA, Wilson de Oliveira. A experiência e a pedagogia que nós surdos queremos. 2007. 147 f. Tese (Doutorado em Educação) - Faculdade de Educação, Universidade Federal do Rio Grande do Sul, Porto Alegre, 2007.

MOITA LOPES, Luiz Paulo da. Introdução: uma Linguística Aplicada mestiça e ideológica: interrogando o campo como linguista aplicado. In: . (Org.). Por uma lingüística aplicada indisciplinar. 2. ed. São Paulo: Parábola Editorial, 2006. p. 13-44.

MOREIRA, Falk Soares Ramos. História de vida e concepção de docentes surdos acerca das políticas de inclusão na educação superior no DF. 2014. 136 f. Dissertação (Mestrado em Educação) - Programa de Pós-Graduação em Educação, Universidade Católica de Brasília, Brasília, 2014.

MOREIRA, Laura Ceretta; FERNANDES, Sueli. Acesso e permanência de estudantes surdos no ensino superior. In: SEMINÁRIO SOBRE INCLUSÃO NO ENSINO SUPERIOR:

TRAJETÓRIA DO ESTUDANTE SURDO, 1., 2008, Londrina. Anais... Londrina: UEPR, 2008. p. 1-6. Disponível em:

<http://www.uel.br/eventos/seminariosurdez/pages/arquivos/palestra_mesa_02_01.pdf>. Acesso em: 3 de outubro de 2016.

MOURA, Maria Cecília. O surdo: caminhos para uma nova identidade. Rio de Janeiro: Editora Revinter, 2000. 152 p.

MÜLLER, Cristiane Ramos. Professor surdo no ensino superior: representações da prática docente. 2009. 82 f. Dissertação (Mestrado em Educação) - Centro de Ciências da Educação, Universidade Federal de Santa Maria, Santa Maria, 2009.

NANTES, Janete de Melo. A constituição do intérprete de língua de sinais no ensino superior na perspectiva dos surdos: o cuidado de si e do outro. 2012. 103 f. Dissertação (Mestrado em Educação) - Faculdade de Educação, Universidade Federal da Grande Dourados, Dourados, 2012. 
NASCIMENTO, Glaucia Renata Pereira do. Aspectos da organização de textos escritos por universitários surdos. 2008. 235 f. Tese (Doutorado em Letras) - Centro de Artes e Comunicação, Universidade Federal de Pernambuco, Recife, 2008.

NEMBRI, Armando Guimarães. O cotidiano escolar do curso bilíngue de pedagogia do Instituto de Educação para Surdos Ines: um olhar avaliativo. 2011. 105 f. Dissertação (Mestrado Profissional em Avaliação) - Fundação Cesgranrio, Rio de Janeiro, 2011.

NICOLAIDES, Christine Siqueira; TILIO, Rogério Casanovas. Políticas de ensino e aprendizagem de línguas adicionais no contexto brasileiro: um caminho trilhado pela Alab. In: NICOLAIDES, Christine et al. Política e políticas linguísticas. Campinas: Pontes, 2013. p. 235-306.

NOGUEIRA, Fabio Luiz Benicio Maia. Políticas institucionais e ações inclusivas nas universidades: análise das condições de acesso para discentes surdos. 2012. $234 \mathrm{f}$. Dissertação (Mestrado em Administração de Empresas) - Fundação Edson Queiroz, Universidade de Fortaleza, Fortaleza, 2012.

OLIVEIRA, Gilvan Müller de. As línguas brasileiras e os direitos linguísticos. In: (Org.). Declaração universal dos direitos linguísticos: novas perspectivas em política linguística. Campinas: Mercado de Letras / Associação de Leitura do Brasil; Florianópolis: IPOL, 2003. p. 7-12.

OLIVEIRA, Janine Soares; WEININGER, Markus Johannes. Densidade de informação, complexidade fonológica e suas implicações para a organização de glossários de termos técnicos da língua de sinais brasileira. Cadernos de Tradução, Florianópolis, v. 2, n. 32, p. 141-163, 2013. Disponível em: <https://periodicos.ufsc.br/index.php/traducao/article/view/2175-7968.2013v2n32p141>. Acesso em: 3 ago. 2015.

OLIVEIRA, Janine Soares de; SILVA, Rodrigo Custódio da. Equipe de tradução do curso de letras libras. In: QUADROS, Ronice Müller (Org.). Letras Libras - ontem, hoje e amanhã. Florianópolis: Edufsc, 2014. p. 93-112.

OLIVEIRA, Maria Marly de. Como fazer pesquisa qualitativa. Petrópolis: Editora Vozes, 2007. $182 \mathrm{p}$.

PACCINI, Viviane Lameu Ribeiro. Caminhos para uma prática inclusiva de leitura e escrita na escola. 2007. 177 f. Dissertação (Mestrado em Educação) - Faculdade de Filosofia e Ciências, Universidade Estadual Paulista "Júlio de Mesquita Filho", Marília, 2007.

PAIVA, Selênia Maria Feitosa e. Construção da identidade de um professor surdo. 2010. 110 f. Dissertação (Mestrado em Educação) - Centro de Educação, Universidade Estadual do Ceará, Fortaleza, 2010.

PATRICIO, Leandro. As políticas públicas de inclusão de surdos no ensino superior: especificidades do processo. 2011. 160 f. Dissertação (Mestrado em Educação) - Faculdade de Ciências Humanas, Letras e Artes, Universidade Tuiuti do Paraná, Curitiba, 2011. 
PEREIRA, Maria Cristina da Cunha. Interação e construção do sistema gestual em crianças deficientes auditivas, filhas de pais ouvintes. 1989. $284 \mathrm{f}$. Tese (Doutorado em Linguística) - Instituto de Estudos da Linguagem, Universidade Estadual de Campinas, Campinas, 1989.

PEREIRA, Naiara Tank. Surdos na universidade: Enem é uma barreira? In: CONGRESSO INTERNACIONAL DE EDUCAÇÃO ESPECIAL E INCLUSIVA, 1., 2016, Marília. Anais... Marília: Unesp, 2016. p. 1-5. Disponível em: <http://www.fundepe.com/jee2016/cd/arquivos/108388.pdf>. Acesso em: 26 jul. 2016.

PEREZ, Maria Alice Rosmaninho. Educação especial em tempos de inclusão: política educacional e laços sociais. 2008. 164 f. Tese (Doutorado em Educação) - Faculdade de Educação, Universidade de São Paulo, São Paulo, 2008.

PERLIN, Gladis T. T. Identidades surdas. In: SKLIAR, Carlos (Org.). A surdez: um olhar sobre as diferenças. 8. ed. Porto Alegre: Mediação, 2016. p. 51-73.

PERSE, Elissandra Lourenço. Ementas de libras nos espaços acadêmicos: que profissionais para qual inclusão? 2011. 202 f. Dissertação (Mestrado em Letras) - Instituto de Letras, Universidade do Estado do Rio de Janeiro, Rio de Janeiro, 2011.

PIMENTA, Nelson; QUADROS, Ronice Müller de. Curso de libras 1: iniciantes. 3. ed. Rio de Janeiro: LSB Vídeo, 2008. 104 f.

PIRES, Álvaro P. Sobre algumas questões epistemológicas de uma metodologia geral para as ciências sociais. In: POUPART, Jean et al. (Org.). A pesquisa qualitativa: enfoques epistemológicos e metodológicos. Tradução de Ana Cristina Nasser. Petrópolis: Vozes, 2008. p. 43-94. (Coleção Sociologia).

PIRES, Cleidi Lovatto; NOBRE, Maria Alzira. Uma investigação sobre o processo de interpretação em língua de sinais. In: THOMA, Adriana Silva; LOPES, Maura Corcini (Org.). A invenção da surdez. Santa Cruz do Sul: Edunisc, 2004. p. 160-187.

PIRES, Edna Misseno. O sucesso escolar de alunos com surdez neurossensorial severo/profunda: a educação em tempos de inclusão/exclusão. 2008. 120 f. Dissertação (Mestrado em Educação) - Departamento de Educação, Universidade Católica de Goiás, Goiânia, 2008.

PIRES, Orion. 'Não entendi nada', afirma estudante surda que prestou a prova do Enem. Globo Notícias Santos, Santos, 10 nov. 2014, Caderno Educação. Disponível em: $<$ http://g1.globo.com/sp/santos-regiao/noticia/2014/11/nao-entendi-nada-afirma-estudantesurda-que-prestou-prova-do-enem.html>. Acesso em: 28 ago. 2016.

POKORSKI, Juliana de Oliveira. Representações na literatura surda: produção da diferença surda no curso de letras-libras. 2014. 147 f. Dissertação (Mestrado em Educação) Faculdade de Educação, Universidade Federal do Rio Grande do Sul, Porto Alegre, 2014.

PRIETO, Rosângela Gavioli. Política educacional do município de São Paulo: estudo sobre o atendimento de alunos com necessidades educacionais especiais, no período de 1986 a 
1996. 2000. 260 f. Tese (Doutorado em Educação) - Faculdade de Educação, Universidade de São Paulo, São Paulo, 2000.

Atendimento escolar de alunos com necessidades especiais: um olhar sobre as políticas públicas de educação no Brasil. In: ARANTES, Valéria Amorim (Org.). Inclusão escolar: pontos e contrapontos. 5. ed. São Paulo: Summus, 2006. p. 31-73. (Pontos e Contrapontos).

QUADROS, Ronice Müller de. Educação de surdos: aquisição da linguagem. Porto Alegre: Artes Médicas, 1997. 126 p.

O tradutor e intérprete de língua brasileira de sinais e língua portuguesa.

Secretaria de Educação Especial / Programa Nacional de Apoio à Educação de Surdos. Brasília: Ministério da Educação; Secretaria de Educação Especial, 2004. 94 p.

Políticas linguísticas e educação de surdos em Santa Catarina: espaço de negociações. Cadernos Cedes, Campinas, v. 26, n. 69, p. 141-161, maio/ago. 2006 a.

Disponível em: <http://dx.doi.org/10.1590/S0101-32622006000200003>. Acesso em: 15 ago. 2015.

. (Org.). Estudos surdos I. Rio de Janeiro: Arara Azul, 2006b. 185 p.

.(Org.). Estudos surdos III. Rio de Janeiro: Arara Azul, 2008. 298 p.

QUADROS, Ronice Müller de; KARNOPP, Lodenir Becker. Língua de sinais brasileira: estudos linguísticos. Porto Alegre: Artmed, 2004. 221 p. (Biblioteca Artmed de Alfabetização e Linguística).

QUADROS, Ronice Müller de; PERLIN, Gladis (Orgs.). Estudos surdos II. Rio de Janeiro: Arara Azul, 2007. 266 p.

QUADROS, Ronice Müller; SCHMIEDT, Magali L.P. Ideias para ensinar português para alunos surdos. Brasília: MEC / SEESP, 2006. 120 p. Disponível em:

<http://portal.mec.gov.br/seesp/arquivos/pdf/port_surdos.pdf〉. Acesso em: 12 maio 2016.

QUADROS, Ronice Müller de; STUMPF, Marianne Rossi (Orgs.). Estudos surdos IV. Rio de Janeiro: Arara Azul, 2008. 450 p.

O primeiro curso de graduação em letras língua brasileira de sinais: educação a distância. Educação Temática Digital, Campinas, v. 10, n. 2, p. 169-185, out. 2009.

Letras Libras EAD. In: QUADROS, Ronice Müller (Org.). Letras libras - ontem, hoje e amanhã. Florianópolis: Edufsc, 2014. p. 9-35.

QUADROS, Waldir; MAIA, Alexandre Gori; GARCIA, Vinicius Gaspar. Perfil social das pessoas com deficiência do Brasil. Base de dados. Campinas, SP, 2015. Disponível em: <http://www.perfilsocial.com.br/index.php\#>. Acesso em: 20 ago. 2015.

RAMOS, Tânia Regina Oliveira. Ensino de literatura e distâncias: experiência de aproximação. Letras de hoje, Porto Alegre, v. 45, n. 3, p. 65-69, jul./set. 2010. 
REBOUÇAS, Larissa Silva. A prioridade dos docentes surdos para ensinar a disciplina língua brasileira de sinais (Libras) nas instituições de ensino superior após o Decreto 5.626/2005. 2009. 170 f. Dissertação (Mestrado em Educação) - Faculdade de Educação, Universidade Federal da Bahia, Salvador, 2009.

REILY, Lucia Helena. As imagens: o lúdico e o absurdo no ensino de arte para pré-escolares surdos. In: SILVA, Ivani Rodrigues; KAUCHAKJE, Samira; GESUELI, Zilda Maria (Org.). Cidadania, surdez e linguagem: desafios e realidades. São Paulo: Plexus, 2003, p. 161-192.

Escola Inclusiva: Linguagem e mediação, Campinas, SP: Papirus, 2004. 188 p. (Série Educação Especial).

ROCHA-COUTINHO, Maria Lúcia. Algumas considerações a respeito do uso da língua dos sinais pelos deficientes auditivos. Trabalhos em linguística aplicada, Campinas, v. 8, p. 7782, 1986.

SÁ-SILVA, Jackson Ronie; ALMEIDA, Cristóvão Domingos de; GUINDANI, Joel Felipe. Pesquisa documental: pistas teóricas e metodológicas. Revista Brasileira de História \& Ciências Sociais, São Leopoldo, v. 1, n. 1, p. 1-15, jan./jul. 2009. Disponível em: <http://www.rbhcs.com/index_arquivos/Artigo.Pesquisa\%20documental.pdf >. Acesso em: 2 abr. 2012.

SACKS, Oliver. Vendo vozes: Uma viagem ao mundo dos surdos. São Paulo: Companhia das Letras, 1998. $196 \mathrm{p}$

SANCHEZ, Carlos. Línguas la lengua escrita: ese esquivo objeto de la pedagogia para sordos y oyentes. In: SKLIAR, Carlos (Org.). Atualidade da educação bilíngue para surdos: interfaces entre pedagogia e linguística. 5. ed. Porto Alegre: Mediação, 2015. v. 2. p. 35-45.

SANTANA, Ana Paula; BERGAMO, Alexandre. A cultura e identidades surdas: encruzilhada de lutas sociais e teóricas. Educação e Sociedade, Campinas, v. 26, n. 91, p. 565-582, 2005.

SÃO PAULO (Município). Orientações curriculares e proposição de expectativas de aprendizagem para a educação infantil e ensino fundamental: língua portuguesa para a pessoa surda. Secretaria Municipal de Educação. São Paulo: SME / DOT, 2008. 128 p.

SARTURI, Claudia de Arruda. Cultura e identidade surda no discurso curricular e seus efeitos na docência de professores formados no curso de Letras/Libras - Polo UFSM. 2013. 91 f. Dissertação (Mestrado em Educação) - Centro de Educação, Universidade Federal de Santa Maria, Santa Maria, 2013.

SCHNEIDER, Elton Ivan. Uma contribuição aos ambientes virtuais de aprendizagem (AVA) suportados pela teoria da cognição situada (TCS) para pessoas com deficiência auditiva. 2012. 180 f. Dissertação (Mestrado em Engenharia e Gestão do Conhecimento) Centro Tecnológico, Universidade Federal de Santa Catarina, Florianópolis, 2012.

SCHUBERT, Silvana Elisa de Morais. Políticas públicas e os sentidos e significados atribuídos pelos educandos surdos ao intérprete de língua de sinais brasileira. 2012. 205 
f. Dissertação (Mestrado em Educação) - Faculdade de Ciências Humanas Letras e Artes, Universidade Tuiuti do Paraná, Curitiba, 2012.

SCHWANDT, Thomas. A. Três posturas epistemológicas para a investigação qualitativa: interpretativismo, hermenêutica e construcionismo social. In: DENZIN, Norman K.;

LINCOLN, Yvona S. O planejamento da pesquisa qualitativa: teorias e abordagens. 2. ed. Tradução Sandra Regina Netz. Porto Alegre: Artmed, 2006. p. 193-217.

SCREMIN, Paula Xavier. A formação dos professores surdos: verdades produzidas na Revista Espaço. 2012. 111 f. Dissertação (Mestrado em Educação) - Universidade de Santa Cruz do Sul, Santa Cruz do Sul, 2012.

SEVERINO, Antônio Joaquim. Metodologia do trabalho científico. 23 ed. São Paulo: Cortez, 2007. 304 p.

SILVA, Ivani Rodrigues. A representação do surdo na escola e na família: entre a representação da diferença e da 'deficiência'. 2005. 280 f. Tese (Doutorado em Linguística Aplicada) - Instituto de Estudos da Linguagem, Universidade Estadual de Campinas, Campinas, 2005.

Quando ele fica bravo, o português sai direitinho; fora disso a gente não entende nada: o contexto multilíngue da surdez e o (re)conhecimento das línguas no seu entorno. Trabalhos em Linguística Aplicada, Campinas, v. 47, n. 2, p. 393-407, jul./dez. 2008.

SILVA, Ivani Rodrigues; FAVORITO, Wilma. Surdos na escola: letramento e bilinguismo. Campinas: Rever, 2009. 80 p. (Coleção linguagem e letramento em foco).

SILVA; Ivani Rodrigues; KUMADA, Kate Mamhy Oliveira. Educação inclusiva e identidades fragmentadas. In: CONGRESSO NACIONAL DE DIVERSIDADE E INCLUSÃO, 2., 2009, Resumos... São Paulo: Núcleo do Parque Tecnológico de São José dos Campos, 2009. 1 CD-ROM.

Representações sobre o contexto multilíngue da surdez. Interdisciplinar, Itabaiana, ano 8, v. 19, n. 1, p. 99-114, jul./dez. 2013.

SILVA, Ivani Rodrigues; KUMADA, Kate Mamhy Oliveira; NOGUEIRA, Aryane Santos. O uso da narrativa como instrumento didático para o ensino de português para surdos. In: SCHEYERL, Denise; SIQUEIRA, Sávio (Org.). Materiais didáticos para o ensino de línguas na contemporaneidade: contestações e proposições. Salvador: Edufba, 2012. p. 251284.

SILVA, Romário Antunes. Usuários de língua brasileira de sinais: perspectivas para repositório educacional aberto. 2011. 186 f. Dissertação (Mestrado em Ciência da Informação) - Centro de Ciências da Educação, Universidade Federal de Santa Catarina, Florianópolis, 2011.

SILVA, Romário Antunes; RODRIGUES, Rosângela Schwarz. Características de repositório educacional aberto para usuários de língua brasileira de sinais. Transinformação, Campinas, v. 25 , n. 1, p. 65-79, jan./ abr. 2013. 
SILVA, Roseane Aparecida Favoreto da. Educação a distância e estudos surdos: experiências de acadêmicos surdos com as tecnologias. 2011. 145 f. Dissertação (Mestrado em Educação) - Setor de Educação, Universidade Federal do Paraná, Curitiba, 2011.

SILVA, Tomaz Tadeu da. A produção social da identidade e da diferença. In: HALL, Stuart; WOODWARD, Kathryn; SILVA, Tomaz Tadeu da (Org.). Identidade e diferença: a perspectiva dos estudos culturais. Petrópolis: Vozes, 2000. p.73-102. (Série Educação póscrítica).

SILVEIRA, Carolina Hessel. O ensino de Libras em escolas gaúchas para surdos: um estudo de currículos. Revista Educação Especial, Santa Maria, n. 31, p. 85-94, 2008.

SILVEIRA, Fernando Lang da; BARBOSA, Maria Cristina Bernardes; SILVA, Roberto da. Exame nacional do ensino médio (ENEM): uma análise crítica. Revista Brasileira de Ensino de Física, Porto Alegre, v. 37, n. 1, p. 1001-1-1001-5, mar. 2015.

SILVEIRA, Flávia Abdon Tavares da Costa. Narrativas de professores de ensino superior sobre o uso da língua portuguesa escrita por surdos. 2007. 127 f. Dissertação (Mestrado em Ciências da Linguagem) - Programa de Pós-Graduação em Ciências da Linguagem, Universidade Católica de Pernambuco, Recife, 2007.

SKLIAR, Carlos. Bilinguismo e biculturalismo: uma análise sobre as narrativas tradicionais na educação de surdos. Revista Brasileira de Educação, Rio de Janeiro, n. 8, p. 44-57, maio/jun./jul./ago. 1998. Disponível em:

<http://www.anped.org.br/sites/default/files/rbe/files/rbe_08.pdf >. Acesso em: 3 ago. 2015.

Introdução: abordagens socioantropológicas em educação especial. In:

(Org.). Educação \& exclusão: abordagens socioantropológicas em educação especial. 3. ed. Porto Alegre: Mediação, 2000. p. 8-20. (Cadernos de autoria).

Pedagogia (improvável) da diferença: e se o outro não estivesse aí? Tradução de Giane Lessa. Rio de Janeiro: DP\&A, 2003. 224 p.

A localização política da educação bilíngue para surdos. In: (Org.).

Atualidade da educação bilíngue para surdos: interfaces entre pedagogia e linguística. 5 . ed. Porto Alegre: Mediação, 2015. p. 7-23.

Um olhar sobre o nosso olhar acerca da surdez e das diferenças. In: . (Org.).

A surdez: um olhar sobre as diferenças. 8 ed. Porto Alegre: Mediação, 2016. p. 5-32.

SKUTNABB-KANGAS, Tove. Bilingualism or not: the education of minorities. Translated by Lars Malmberg and David Crane. Clevedon: Multilingual Matter, 1981. 400 p. (Multilingual Matters, 7).

SOARES, Rúbem da Silva. Educação bilíngue de surdos: desafios para a formação de professores. 2013. 138 f. Dissertação (Mestrado em Educação) - Faculdade de Educação, Universidade de São Paulo, São Paulo, 2013. 
SOFIATO, Cassia Geciauskas. Do desenho à litografia: a origem da língua brasileira de sinais. 2011. 265 f. Tese (Doutorado em Artes) - Instituto de Artes, Universidade Estadual de Campinas, Campinas, 2011.

SOUZA, Regina Maria de. Língua de sinais e escola: considerações a partir do texto de regulamentação da língua brasileira de sinais. Educação temática digital, Campinas, v. 7, n. 2, p. 266-281, 2006.

SOUZA, Rosemeri Bernieri; SEGALA, Rimar Ramalho. A perspectiva social na emergência das línguas de sinais: a noção de comunidade de fala e idioleto segundo o modelo teórico laboviano. In: QUADROS, Ronice Müller; STUMPF, Marianne Rossi (Org.). Estudos Surdos IV. Petrópolis: Arara Azul, 2009. p. 21-48.

STOKOE JR., William C. Sign language structure: an outline of the visual communication systems of the american deaf. Studies in linguistics: Occasional papers, Buffalo, v. 71, n. 2, p. 269-271, apr./jun., 1961.

STROUD, Christopher. Rinkeby Swedish and semilingualism in language ideological debates: a Bourdieuean perspective. Journal of Sociolinguistics, Malden, v. 8, n. 2, p. 196214, 2004.

STUMPF, Marianne Rossi; OLIVEIRA, Janine Soares; MIRANDA, Ramon Dutra. Glossário Letras-Libras a trajetória dos sinalários no curso: como os sinais passam a existir. In.: QUADROS, Ronice Müller (Org.). Letras Libras - ontem, hoje e amanhã. Florianópolis: Edufsc, 2014. p. 169-190.

TAGATA, William Mineo. Omo's wash keeps England in the black: hibridismo em Minha Adorável Lavanderia e outros espaços intersticiais. 2007. 235 f. Tese (Doutorado em Estudos Linguísticos e Literários em Inglês) - Faculdade de Filosofia, Letras e Ciências Humanas, Universidade de São Paulo, São Paulo, 2007.

TERRA, Ernani; NICOLA NETO, José de. 1.001 dúvidas de português. 7. ed. São Paulo: Saraiva, 1999. 264 p.

TERVOORT, Bernard T. Esoteric simbolism in the communication behaviour of young deaf children. American Annals of the Deaf, Washington, 106, p. 436-480, 1961.

THOMA, Adriana da Silva. O cinema e a flutuação das representações surdas: "que drama se desenrola neste filme? Depende da perspectiva...”. 2002. 258 f. Tese (Doutorado em Educação) - Faculdade de Educação, Universidade Federal do Rio Grande do Sul, Porto Alegre, 2002.

A inclusão no ensino superior: ninguém foi preparado para trabalhar com esses alunos... isso exige certamente uma política especial. In: REUNIÃO ANUAL DA ANPED, 29., 2006, Caxambu. Anais... Caxambu: Anped, 2006. p. 1-18. Disponível em:<http://29reuniao.anped.org.br/trabalhos/trabalho/GT15-2552--Int.pdf >. Acesso em: 3 ago. 2015.

Surdos: esse "outro" de que fala a mídia. In: SKLIAR, Carlos (Org.). A surdez: um olhar sobre as diferenças. 8. ed. Porto Alegre: Mediação, 2016. p.121-136. 
THOMA, Adriana da Silva; KLEIN, Madalena. Experiências educacionais, movimentos e lutas surdas como condições de possibilidades para uma educação de surdos no Brasil. Cadernos de Educação, Pelotas, n. 36, p. 107-131, maio/ago. 2010. Disponível em: <http://periodicos.ufpel.edu.br/ojs2/index.php/caduc/issue/view/156>. Acesso em: 3 ago. 2015.

TRAVESSIA do silêncio. Direção: Dorrit Harazim. Rio de Janeiro: Vídeo Filmes, 2004. 1 DVD (58 min), son., color.

UNIVERSIDADE ESTADUAL DE CAMPINAS. Processo seletivo - 2016. Campinas: Unicamp, 2015. Disponível em: <http://www.fcm.unicamp.br/fcm/sites/default/files/paganex/editaldedivulgacao_2016_sir.pdf >. Acesso em: 28 ago. 2015.

UNIVERSIDADE FEDERAL DA GRANDE DOURADOS. Edital n. 1 (2013-1). Dourados: UFGD, 13 maio 2013. 16 p. Disponível em:

<http://portal.ufgd.edu.br/vestibular/psvlibras2013/editais/Edital_de_Abertura_Libras.pdf.>. Acesso em: 6 jan. 2015.

UNIVERSIDADE FEDERAL DA PARAÍBA. Edital n. 40 (2009-2). João Pessoa: UFPB, 27 ago. 2009. 5 p. Disponível em: <http://portal2.virtual.ufpb.br/wpcontent/uploads/2014/08/edital402009_libras.pdf>. Acesso em: 5 jan. 2016.

Resolução n. 03 (2010). João Pessoa: UFPB, 19 mar. 2010. 4 p. Disponível em: <http://www.cchla.ufpb.br/libras/?page_id=25>. Acesso em: 5 jan. 2016.

Edital n. 30 (2011-2). João Pessoa: UFPB, 19 out. 2011. 7 p. Disponível em: $<$ http://portal2.virtual.ufpb.br/wp-content/uploads/2014/08/Edital-n\%C2\%BA-30-2012COPERVE-Curso-deLIBRAS.pdf >. Acesso em: 5 jan. 2016.

Edital n. 35 (2013-2). João Pessoa: UFPB, 09 dez. 2013.13 p. Disponível em: <http://portal2.virtual.ufpb.br/wp-content/uploads/2014/08/Edital-35-2013-Processo-SeletivoEAD.pdf.>. Acesso em: 11 maio 2016.

UNIVERSIDADE FEDERAL DE GOIÁS. Edital n. 081 (2008-2). Goiânia: UFG, 20 ago. 2008. 25 p. Disponível em: 〈http://www.vestibular.ufg.br/ps2009/edital_81_2008.pdf〉. Acesso em: 11 jan. 2016.

Edital n. 69 (2009-2). Goiânia: UFG, 4 set. 2009. 21 p. Disponível em: <http://www.vestibular.ufg.br/ps2010-1/editais/edital-69_PS2010-1.pdf〉. Acesso em: 29 jun. 2016.

Edital n. 66 (2010-2). Goiânia: UFG, 16 set. 2010. 24 p. Disponível em: <http://www.vestibular.ufg.br/ps2011-1/edital/Edital_PS2011.pdf >. Acesso em:18 jan. 2016.

Edital n. 77 (2013-2). Goiânia: UFG, 06 set. 2013. 41 p. Disponível em: <http://download.uol.com.br/vestibular2/edital/ufg_2014retificado.pdf >. Acesso em: 22 jan. 2016. 
Edital n. 1 (2015-1). Goiânia: UFG, 06 jan. 2015. 21 p. Disponível em:

<http://vestibular.ufg.br/2015/ps2015_1/sistema/edital/Edital_01_2015_unificado_ps_2015_1 .pdf $>$. Acesso em: 26 jan. 2016.

UNIVERSIDADE FEDERAL DE PERNAMBUCO. Edital 2014.2 (2014-2). Recife: UFPE, 22 jul. 2014. 14 p. Disponível em: 〈http://covest.com.br/downloads/EDITAL_LIBRAS.pdf.>. Acesso em: 5 maio 2016.

UNIVERSIDADE FEDERAL DE SANTA CATARINA. Sétimo Prolibras. Florianópolis: Ufsc, 2015. Disponível em: <http://www.prolibras.ufsc.br/edicoes-anteriores/>. Acesso em: 26 ago. 2015.

Edital n. 7 (2006-2). Florianópolis: Ufsc, 07 jul. 2006.9 p. Disponível em: <http://antiga.coperve.ufsc.br/ead2006/libras/edital/editalcompleto.pdf >. Acesso em: 25 jun. 2015.

Edital n. 1 (2008-1). Florianópolis: Ufsc, 09 abr. 2008. 10 p. Disponível em: <http://antiga.coperve.ufsc.br/ead2008/libras/edital/editalcompleto.pdf>. Acesso em: 25 jun. 2015.

Edital n. 2 (2009-1). Florianópolis: Ufsc, 22 abr. 2009. 11 p. Disponível em: <http://www.vestibular2009libras.ufsc.br/edital/edital_completo.pdf>. Acesso em: 27 jun. 2015 .

Edital n. 2 (2010-1). Florianópolis: Ufsc, 25 maio 2010. 9 p. Disponível em: <http://www.vestibular2010.ufsc.br/libras/edital/edital_completo.pdf>. Acesso em: 27 jun. 2015.

Edital n. 5 (2011-2). Florianópolis: Ufsc, 11 ago. 2011.17 p. Disponível em: <http://www.vestibular2012.ufsc.br/edital/edital_completo.pdf $>$. Acesso em: 27 jun. 2015.

Edital n. 4 (2012-2). Florianópolis: Ufsc, 17 set. 2012.14 p. Disponível em: <http://www.vestibular2013.ufsc.br/files/2012/07/Edital_Completo_04COPERVE2012.pdf>. Acesso em: 3 ago. 2015.

Edital n. 4 (2013-2). Florianópolis: Ufsc, 25 set. 2013. 18 p. Disponível em: <http://www.vestibular2014.ufsc.br/files/2012/07/edital04-vest2014.pdf>. Acesso em: 17 ago. 2015.

Edital n. 2 (2014-1). Florianópolis: Ufsc, 25 mar. 2014. 12 p. Disponível em: <http://libras2014.paginas.ufsc.br/files/2014/04/Edital-ead-libras-2014_retificado2.pdf>. Acesso em: 25 jun. 2015.

Edital n. 5 (2014-2). Florianópolis: Ufsc, 04 set. 2014. 21 p. Disponível em: <http://www.vestibular2015.ufsc.br/files/2014/09/Edital05-vest2015-final.pdf>. Acesso em: 25 jun. 2015.

UNIVERSIDADE FEDERAL DE SERGIPE. Edital n. 4 (2014-1). São Cristóvão: UFS, 28 fev. 2014. 2 p. Disponível em: 
<http://www2.ccv.ufs.br/ccv/concursos/libras2014/files/EditalVest2014_Internet_Libras\%20 Minuta_Manuel.pdf $>$. Acesso em: 30 maio 2016.

Edital n. 8 (2014-2). São Cristóvão: UFS, 25 ago. 2014.3 p. Disponível em:

<http://www2.ccv.ufs.br/ccv/concursos/libras2015/files/EditalPS2015_INTERNET_Letras\%2 0Libras.pdf $>$. Acesso em: 30 maio 2016.

UNIVERSIDADE FEDERAL DE UBERLÂNDIA. Edital n. 9 (2013-2). Uberlândia: UFU, 19 dez. 2013. 7 p. Disponível em:

<http://www.ingresso.ufu.br/sites/default/files/anexos/procsel/20141/PS20141_Edital_09.pdf >. Acesso em: 29 jun. 2016.

UNIVERSIDADE FEDERAL DO ACRE. Edital n. 02 (2013-2). Rio Branco: Ufac, 30 dez. 2013. 17 p. Disponível em: <http://www.ufac.br/portal/editais-concursos/prograd/editalprograd-no-02-2014-processo-seletivo-especifico-para-ingresso-nos-cursos-de-graduacao-deletras-libras-licenciatura-musica-licenciatura-e-psicologia-

bacharelado/Edital_Processo_Seletivolibrasmsicaepsicologiaretificado.pdf>. Acesso em: 29 jun. 2016.

UNIVERSIDADE FEDERAL DO ALAGOAS. Edital n. 09 (2015-1). Maceió: Ufal, 24 abr. 2015. 24 p. Disponível em:

$<$ http://www.copeve.ufal.br/sistema/anexos/Processo\%20Seletivo\%20UFAL\%202015\%20$\% 20$ Licenciatura\%20em\%20Letras\%20-\%20LIBRAS/Edital.pdf>. Acesso em: 30 maio 2016.

UNIVERSIDADE FEDERAL DO AMAPÁ. Edital n. 14 (2014-2). Macapá: Unifap, 26 dez. 2014. 17 p. Disponível em: <https://depsec.unifap.br/index.php?c=lib15>. Acesso em: 9 mar. 2016.

UNIVERSIDADE FEDERAL DO AMAZONAS. Edital n. 41 (2014-2). Manaus: Ufam, 13 jul. 2014. 40 p. Disponível em:

<http://www.comvest.ufam.edu.br/arquivo/psc2015/Edital_41psc_2015.pdf >. Acesso em: 8 mar. 2016.

UNIVERSIDADE FEDERAL DO CEARÁ. Edital n. 13 (2014-1). Fortaleza: UFC, 16 maio 2014. 11 p. Disponível em:

<http://www.prograd.ufc.br/images/files/editais_resultados/2014/edital_13/edital_013_2014_ selecao_letras_libras_2014_2.pdf>. Acesso em: 16 mar. 2016.

Edital n. 11 (2015-1). Fortaleza: UFC, 14 maio 2015. 12 p. Disponível em:

<http://www.prograd.ufc.br/images/files/editais_resultados/2015/edital_11/edital_011_2015_ selecao_libras_2015_2.pdf>. Acesso em: 16 mar. 2016.

UNIVERSIDADE FEDERAL DO MARANHÃO. Edital n. 305 (2014-2). São Luis: UFMA, 10 dez. 2014. 29 p. Disponível em: <http://www.concursos.ufma.br/editais/1814.pdf.>.

Acesso em: 13 mar. 2016.

UNIVERSIDADE FEDERAL DO PARÁ. Edital n. 8 (2010-2). Belém: UFPA, 1 set. 2010. 13 p. Disponível em:

<http://www3.ceps.ufpa.br/daves/PS2011/EDITAL_PS_UFPA_2011.pdf.>. Acesso em: 8 mar. 2016. 
Edital n. 7 (2011-2). Belém: UFPA, 12 set. 2011.14 p. Disponível em:

<http://www3.ceps.ufpa.br/daves/processo_seletivo_2012.htm>. Acesso em: 29 jun. 2016.

UNIVERSIDADE FEDERAL DO PARANÁ. Edital n. 23 (2014-2). Curitiba: UFPR, 27 out. 2014. 21 p. Disponível em:

<http://www.nc.ufpr.br/concursos_institucionais/libras/2015/documentos/edital232014.pdf>.

Acesso em: 25 jun. 2015.

UNIVERSIDADE FEDERAL DO PIAUÍ. Caderno de questões (2015-1a). Teresina: UFPI, 28 jun. 2015, 8 p. Disponível em:

<http://copese.ufpi.br/subsiteFiles/copesenovo/arquivos/files/proc_seletivo_libras2015_.pdf>. Acesso em: 14 mar. 2016.

Edital n. 7 (2015-1b). Teresina: UFPI, 7 maio 2015. 16 p. Disponível em:

$<$ http://copese.ufpi.br/subsiteFiles/copesenovo/arquivos/files/Edital\%20Letras-

Libras\%202015_2(1).pdf>. Acesso em: 14 mar. 2016.

UNIVERSIDADE FEDERAL DO RIO DE JANEIRO. Edital n. 79 (2014-1). Rio de Janeiro: UFRJ, 10 abr. 2014. 5 p. Disponível em: <https://ufrj.br/docs/editais/2014/edital-2014-0411_13-34.pdf>. Acesso em: 29 jun. 2016.

Edital n. 307 (2014-2). Rio de Janeiro: UFRJ, 30 set. 2014. 15 p. Disponível em: <https://ufrj.br/docs/editais/2014/edital-2014-10-14_14-35.pdf〉. Acesso em: 29 jun. 2016.

UNIVERSIDADE FEDERAL DO RIO GRANDE DO NORTE. Edital n. 2 (2013-1). Natal: UFRN, 27 maio 2013. 9 p. Disponível em:

<http://www.comperve.ufrn.br/conteudo/graduacao/letras_201302/arquivos/editalemlibras.ph p>. Acesso em: 20 abr. 2016.

UNIVERSIDADE FEDERAL DO TOCANTINS. Edital n. 1 (2015-1). Palmas: UFT, 15 jan. 2015. 38 p. Disponível em:

$<$ http://www.copese.uft.edu.br/index.php?option=com_docman\&task=doc_download\&gid=4 139>. Acesso em: 2 mar. 2016.

UNIVERSIDADE FEDERAL RURAL DA AMAZÔNIA. Edital n. 2 (2015-1). Belém: Ufra, 18 maio 2015. 16 p. Disponível em:

<https://portal.ufra.edu.br/index.php?option=com_content\&view=article\&id=298:edital-deconvocacao-de-matriculas-do-parfor-ufra-licenciatura-em-letras-libras-2chamada\&catid=17\&Itemid=542>. Acesso em: 5 set. 2016.

Edital n. 2 (2014-1). Natal, UFRN, 28 abr. 2014. 10 p. Disponível em:

<http://www.comperve.ufrn.br/conteudo/graduacao/letras_201402/documentos/edital_201402 .pdf>. Acesso em: 25 abr. 2016.

Edital n. 1 (2015-1). Natal: UFRN, 29 abr. 2015.9 p. Disponível em:

<http://www.comperve.ufrn.br/conteudo/graduacao/letras_201502/documentos/edital_201504 29.pdf >. Acesso em: 25 abr. 2016. 
UNIVERSIDADE NACIONAL DE BRASÍLIA. Edital nº 1. (2014-2). Brasília: UNB, 20 nov. 2014a. 28 p. Disponível em:

<http://www.cespe.unb.br/vestibular/vestunb_15_1_libras/arquivos/ABT__VEST_LIBRAS. PDF>. Acesso em: 18 fev. 2015.

Edital no 2 (2014-2). Brasília: UNB, 4 dez. 2014b. 2 p. Disponível em:

<http://www.cespe.unb.br/vestibular/vestunb_15_1_libras/arquivos/VEST_LIBRAS__ED_2 _RETIFICA___O.PDF>. Acesso em: 18 fev. 2015.

VALIANTE, Juliana Brazolin Gomes. Língua brasileira de sinais: reflexões sobre sua oficialização como instrumento de inclusão dos surdos. 2009. 98 f. Dissertação (Mestrado em Linguística) - Instituto de Estudos da Linguagem, Universidade Estadual de Campinas, Campinas, 2009.

VIANA, Nelson. Planejamento de cursos de línguas: pressupostos e percurso. In: ALMEIDA FILHO, José Carlos Paes (Org.). Parâmetros atuais para o ensino de português língua estrangeira. Campinas: Pontes, 1997, p. 29-48.

VIEIRA-MACHADO, Lucyenne Matos da Costa. Formação de professores de surdos: dispositivos para garantir práticas discursivas. Cadernos de Educação, Pelotas, n. 36, p. 4568, maio/ago. 2010. Disponível em:

<http://periodicos.ufpel.edu.br/ojs2/index.php/caduc/issue/view/156>. Acesso em: 15 ago. 2015.

VILHALVA, Shirley. Mapeamento das línguas de sinais emergentes: um estudo sobre as comunidades linguísticas indígenas de Mato Grosso do Sul. 2009. 124 f. Dissertação (Mestrado em Linguística) - Centro de Comunicação e Expressão, Universidade Federal de Santa Catarina, Florianópolis, 2009.

Índios surdos: mapeamento das línguas de sinais do Mato Grosso do Sul.

Petrópolis: Arara Azul, 2012.

WOODWARD, Kathryn. Identidade e diferença: uma introdução teórica e conceitual. In: HALL, Stuart; WOODWARD, Kathryn; SILVA, Tomaz Tadeu da (Org.). Identidade e diferença: a perspectiva dos estudos culturais. Petrópolis: Vozes, 2000. p. 7-72. (Série Educação pós-crítica). 